Migration and Integration in Europe, Southeast Asia, and Australia 


\section{IIAS Publications}

International Institute

for Asian Studies

The International Institute for Asian Studies is a research and exchange platform based in Leiden, the Netherlands. Its objective is to encourage the interdisciplinary and comparative study of Asia and to promote (inter)national cooperation. IIAS focuses on the humanities and social sciences and on their interaction with other sciences. It stimulates scholarship on Asia and is instrumental in forging research networks among Asia Scholars. Its main research interest are reflected in the three book series published with Amsterdam University Press: Global Asia, Asian Heritages and Asian Cities.

IIAS acts as an international mediator, bringing together various parties in Asia and other parts of the world. The Institute works as a clearinghouse of knowledge and information. This entails activities such as providing information services, the construction and support of international networks and cooperative projects, and the organisation of seminars and conferences. In this way, IIAS functions as a window on Europe for non-European scholars and contributes to the cultural rapprochement between Europe and Asia.

IIAS Publications Officer: Paul van der Velde

IIAS Assistant Publications Officer: Mary Lynn van Dijk

\section{Global Asia}

Asia has a long history of transnational linkage with other parts of the world. Yet the contribution of Asian knowledge, values, and practices in the making of the modern world has largely been overlooked until recent years. The rise of Asia is often viewed as a challenge to the existing world order. Such a bifurcated view overlooks the fact that the global order has been shaped by Asian experiences as much as the global formation has shaped Asia. The Global Asia Series takes this understanding as the point of departure. It addresses contemporary issues related to transnational interactions within the Asian region, as well as Asia's projection into the world through the movement of goods, people, ideas, knowledge, ideologies, and so forth. The series aims to publish timely and well-researched books that will have the cumulative effect of developing new perspectives and theories about global Asia.

Series Editor: Tak-Wing Ngo, Professor of Political Science, University of Macau, China

Editorial Board: Kevin Hewison, Sir Walter Murdoch Distinguished Professor of Politics and International Studies, Murdoch University, Australia / Hagen Koo, Professor of Sociology, University of Hawaii, USA / Loraine Kennedy, Directrice de recherche, Centre d'Études de l'Inde et de l'Asie du Sud, École des Hautes Études en Sciences Sociales, France / Guobin Yang, Associate Professor, Annenberg School for Communication, University of Pennsylvania, USA 


\title{
Migration and Integration in Europe, Southeast Asia, and Australia
}

\author{
A Comparative Perspective
}

Edited by

Juliet Pietsch and Marshall Clark 


\section{IIAS Publications}

International Institute

for Asian Studies

\section{Global Asia 6}

Cover illustration: @ Nanang Indra Kurniawan

Cover design: Coördesign, Leiden

Typesetting: Crius Group, Hulshout

Amsterdam University Press English-language titles are distributed in the US and Canada by the University of Chicago Press.

$$
\begin{array}{ll}
\text { ISBN } & 978 \text { 90 } 89645388 \\
\text { e-ISBN } & 9789048528172 \text { (pdf) } \\
\text { NUR } & 741 \mid 763
\end{array}
$$

(c) Juliet Pietsch and Marshall Clark / Amsterdam University Press, Amsterdam 2015

All rights reserved. Without limiting the rights under copyright reserved above, no part of this book may be reproduced, stored in or introduced into a retrieval system, or transmitted, in any form or by any means (electronic, mechanical, photocopying, recording or otherwise) without the written permission of both the copyright owners and the authors of the book. 


\section{Contents}

Contents

List of tables and figures

Acknowledgements

1 Introduction

The comparative study of migration flows

Juliet Pietsch

2 Shifting migration flows and integration policies in Europe

An overview

Pawet Kaczmarczyk, Magdalena Lesińska \& Marek Okólski

3 Public opinion towards new migration flows in Europe and the increasing role of the EU

Juliet Pietsch

4 Shifting dilemmas

Multiculturalism and integration policies in Europe James Jupp

5 Malaysia

Labour migration, irregular movements and regional policies Amarjit Kaur

6 Labour migration flows and regional integration in Southeast Asia 99 Marshall Clark

7 Transiting asylum seekers in Indonesia

Between human rights protection and criminalisation

Antje Missbach

8 Abrogating human rights responsibilities

Australia's asylum-seeker policy at home and abroad

Linda Briskman \& Victoria Mason 
9 Courting disaster?

Regional agreements for 'protection elsewhere' and the courts

Penelope Mathew

10 Maritime pathways

Temporary migration flows from Indonesia to Australia Marshall Clark \& Dedi Supriadi Adhuri

Bibliography

Contributors 


\section{List of tables and figures}

\section{Tables}

Table 3.1 Public support for EU institutions, 2009

Table 3.2 Public perception of the most important problems facing the Netherlands, 2009

Table 4.1 Foreign born and Muslim population of 21 selected democracies 60

Table 4.2 Support for anti-immigration parties in Europe and Australasia

Table 5.1 Singapore, Malaysia, Thailand, Indonesia and the Philippines: main economic indicators $2010 \quad 82$

Table 5.2 Proportion of migrant workers in Malaysia's main economic sectors $\quad 89$

Table 5.3 Countries of origin of foreign workers approved for recruitment to Malaysia, $2008 \quad 89$

Table 8.1 Asylum applications in Australia from Iraqis and Afghans 151

Figures

Figure 3.1 Perceptions of respondents in EU countries of the impact of EU migration policies on their countries, $2009 \quad 52$

Figure 3.2 Public support for decrease in immigration levels in EU countries, 2009

Figure 5.1 Malaysia: Foreign workers by country of origin (per cent), 1999-2008

Figure 10.1 The MoU Box 



\section{Acknowledgements}

We wish to thank the Australian National University's College of Arts and Social Sciences for funding this project during the period 2010-2013. We are grateful for the support of Professor Jacqueline Lo and the ANU Centre for European Studies, which hosted several international workshops on global and regional migration flows. We thank Professor Timothy Hatton and Professor Ellen Percy Kraly for reading several chapters and providing advice on various aspects of international migration and population movements, specifically within the European context. We acknowledge the helpful input of Richard Towle of the United Nations High Commissioner for Refugees (UNHCR) at an early stage in this project. We also acknowledge the contributors to this book, all of whom demonstrated unwavering support, which is unusual for long-term enterprises such as this. We much appreciate Martina van den Haak, Mary Lynn van Dijk and especially Paul van der Velde from the International Institute for Asian Studies for their ongoing support, guidance and encouragement in preparing this manuscript for publication. A warm thanks to Rachel Salmond for her final editing of our manuscript. Finally, we wish to acknowledge the anonymous reviewers at the Amsterdam University Press for their critical comments and valuable suggestions, all of which have much improved this project. 



\title{
$1 \quad$ Introduction
}

The comparative study of migration flows

\author{
Juliet Pietsch
}

Scholars and other commentators working within the field of comparative migration studies have long been evaluating the many national and regional trends of regular and irregular migration. Comparative studies of migration in the East and in the West, however, have been less prominent. Within a comparative East-West framework, this volume takes a multidisciplinary approach to the key issues relating to migration, in particular new migration trends, regional integration and citizenship, regional labour standards, irregular migration and human rights protections for refugees, with a particular focus on Europe, Southeast Asia and Australia.

Why examine new migration flows at this particular moment in time? With increasing integration of trade, peoples and cultures both within and across regions, the acceptance and integration of new migrants and refugees are now pressing issues in Europe, Southeast Asia and Australia, where a number of national and regional frameworks on immigration have been implemented. The movement of refugees and asylum seekers, in particular, has become a heavily politicised issue as Western countries not only tighten their borders to regular forms of migration but also restrict access to citizenship and cultural diversity rights for migrants with legal and illegal status. Restrictions on access to citizenship and the tightening of national borders have made it harder for people in desperate situations to flee and begin a new life in another part of the world. These issues have arisen as a result of events occurring largely in other parts of the world, where there is a great deal of death, destruction, fear and displacement in nations such as Afghanistan, Iraq and Syria. Civil war and political upheaval in nations such as Sri Lanka and Libya, and other forms of repression, internal conflict and natural disasters as experienced by nations such as Burma, have led to remarkable changes in human movement and labour migration patterns.

While in Europe, the European Union (EU) project and the associated increase in the movement of people across borders has brought significant challenges to the region, widespread people movement has also become a significant issue for various governments in the Asia-Pacific region. The government of Malaysia, for instance, is presently hosting up to 80,000 
transit migrants (including refugees and asylum seekers), as well as between four and six million migrant workers, many of whom are irregular migrants without legal status. The government of Indonesia, preoccupied by the demands of a chaotic yet relatively successful democratisation process, is struggling to manage the dual problems of irregular people movement and people smuggling. The government of Australia is also experiencing difficulty in addressing public concerns about the relatively small number of asylum seekers arriving by boat from Southeast Asia. Given the fundamentally transnational nature of migration flows, comparing a variety of national and regional responses to regular and irregular people movement is both timely and important. This is especially so given the increasingly vociferous calls in each of the regions examined in this book to envision and enact a truly regional solution or framework for managing people movement and in some countries increasing cultural diversity.

Europe has been chosen as the first point of comparison in this book for several reasons. First, EU cooperation on migrant worker and asylum and refugee policies has experienced substantial tensions between regional and national solutions. A similar pattern is occurring in Southeast Asia and Australia, with tensions between regional forums (such as the Association of Southeast Asian Nations, or ASEAN, and the Bali Process) and national or bilateral arrangements (such as Indonesia's moratorium on sending migrant workers to Malaysia between 2010 and 2011, Howard, Gillard, Rudd and Abbott governments, which has involved arrangements between the governments of Australia, Nauru and Papua New Guinea). Second, Europe has experienced tension between refugee human rights protection and the restrictive approaches in EU legislation. Third, many countries in Europe are relatively new migration destinations and are therefore experimenting with a variety of integration programmes and citizenship policies. Given Southeast Asia's legal, cultural and political diversity, as well as the emphasis in each of the region's component nations on defending its national sovereignty, analysing Europe's experience in this regard can be useful for understanding the dynamics of migration in Southeast Asia. Like Europe, Australia is also witness to ongoing tension between refugee advocates such as the United Nations High Commissioner for Refugees (UNHCR), on the one hand, and the government, which is trending towards more restrictive immigration policies and legislation, on the other. 


\section{Linking the past with the present}

Throughout Europe, Southeast Asia and, more recently, Australia, new pathways of migration are extremely diverse, with different outcomes for migrants in terms of their legal, political and cultural rights. In many cases, skilled and temporary migration creates new opportunities for migrants (Oke 2012). However, other categories of migration, such as irregular or asylum-seeking migration, are subject to vulnerabilities associated with the lack of provision of economic, social, cultural and political rights, which vary from country to country and across regions (McNevin 2011). Long-term migrants are also vulnerable in times of economic and financial crisis. Using a comparative multidisciplinary perspective, we show that, despite very different cultures, histories and trajectories, there is considerable overlap in public and political discussions on how to respond to new migration flows in Europe, Southeast Asia and Australia.

New migration flows not only depend on so-called 'push' factors, such as economic hardship and political instability, and 'pull' factors, such as stability and prosperity, but also on histories and networks that have linked people and communities for generations (Portes 1995). For example, post-war migration between European countries and their former colonies was structured by the centuries-old colonial encounters as well as by the demand in Europe for migrant workers from former colonies. Some European nations, such as the Netherlands, even needed to relocate workers from some colonies (the Dutch East Indies in the case of the Netherlands) to work as indentured labourers in other colonies (Suriname) (Allen 2011; Hoefte 1998; Termorshuizen 2008). But not all historical links have acted as convincing 'pull factors' in the 21st century. For instance, Australia's well-documented heritage of Afghan cameleers, many of whom helped construct the inland railroad system in the nineteenth century (Ganter 2006), has not made it any easier for today's generation of Afghan refugees to seek asylum in Australia. Similarly, the large number of Javanese migrants working in nineteenth- and twentieth-century colonial Malaya had little impact on Prime Minister Mahathir's unsentimental 'Hire Indonesians Last' policy of 2002, which aimed to halve the number of Indonesian workers in Malaysia (Ford 2006; Liow 2006). Historical confluences, it appears, cannot always be relied on as a means of unlocking the dilemmas of contemporary decision-making on new migration trends.

Even if salient connections between the past and the present are sometimes ignored, understanding the history of migration flows is nonetheless important. Throughout history, migration flows have occurred before, during 
and after major social and political upheavals, or to put it another way, during peacetime and war. For example, in the 1930s nearly a third of the French population were migrants, mostly from southern Europe (Caldwell 2009). Likewise, in mainland and maritime Southeast Asia there has been a long and established history of intra-regional migration, occurring before, during and after major upheavals, such as colonialism. Transnational flows of people, trade and material culture occurred between the islands and communities of the Indonesian archipelago, Peninsular Malaysia and the Philippines for centuries, predating colonialism, globalisation and industrialisation (Andaya 2008; Milner 2009). Elsewhere in the region, Macassans - Indonesian trepang (sea cucumber) fishermen who regularly voyaged to northern Australia at least a century or more before European settlement - enjoyed a great deal of social, cultural and trade-related contact with Aboriginal communities (Clark \& May 2013; Macknight 1976; Ganter 2006). The historical resonances of this encounter have extended to the present day, when many cultural and linguistic borrowings from the Macassans are still evident in the arts and languages of Indigenous Australians, particularly in the Yolngu of Arnhem Land. Throughout the world, migrant networks are consolidated by transnational communities over many generations, thus building strong links between what have been termed in contemporary parlance 'sending' and 'receiving' countries (Faist 2000; Messina 1996; Vertovec 1999).

While there has been a long history of migration in Europe, Southeast Asia and Australia, this edited collection focuses on migration flows since the 199os. Since the 1990s there has been a remarkable convergence in policymaking in Europe, Southeast Asia and Australia on how best to respond to regular and irregular migration flows across borders and to new dilemmas relating to increasing patterns of cultural diversity. Such policies are characterised by demands from neighbouring countries, public opinion and regional authorities to introduce legislation that will enable governments to control their borders more effectively and be seen to be managing social cohesion. I will now shift the introductory focus specifically to migration studies in Europe in order to see how institutions and organisations have received migrants from diverse backgrounds. I will then draw preliminary comparisons with the Southeast Asian and Australian cases.

\section{Comparative approaches to migration studies}

The intensification of the immigration debate in pluralist democratic societies reflects a number of global forces such as globalisation, transnational 
networks, increasing economic integration and rising political instability around the world. Interdisciplinary approaches have been used to examine some of the connecting themes that have emerged in comparative migration politics in Europe since the 1990s. A number of different approaches have been taken in attempts to account for the gap between restrictionist interventions and more liberal policy outcomes.

One approach is related to the idea that migration flows are by and large shaped by globalisation and institutions beyond the nation-state. Globalisation theorists (Bauböck 1994; Sassen 1996; Soysal 1994) primarily focus on the effects of globalisation and the impact of supranational institutions such as the EU in the diminishing importance of the state in immigration policymaking. Regional and international human rights mechanisms limit the capacity of nation-states to impose maximum restrictions.

A second approach draws on political economy perspectives (Freeman 1995, 1998, 2006), which recognise an interest among nation-states to limit certain categories of immigration and expand others that are beneficial for the nation's economy. Drawing on a political economy perspective, Freeman suggests that big business interests and demand for cheap labour largely influence domestic policies on immigration. Politicians tend to maximise utility by weighing up the costs and benefits of different categories of immigration in terms of the national interest. Researchers have argued that the threat of labour market competition and perceptions of migrants as a burden on the welfare system are significant factors underpinning the politics of migration (Dustmann \& Preston 2007; Facchini \& Mayda 2006; Scheve \& Slaughter 2001a, 2001b).

A third approach compares integration and citizenship policies across countries. These studies look at the benefits of assimilation, integration and multiculturalism for both new and long-term migrants. Views about national identity and the extent to which migrants should be able to maintain their own cultures and belief systems have been the subject of many theoretical and policy debates in Europe, North America and Australia (Habermas 1994; Joppke 2005; Koopmans \& Stratham 1999; Kymlicka 1995, 2003). In response to increasing immigration and concerns about national identity, most European countries have developed integration policies based on differing political traditions, citizenship and nationhood (Brubaker 20o1; Favell 2001; Ireland 2004).

A fourth approach examines the role of courts, bureaucracies and refugee advocates in questioning, limiting or even launching legal injunctions against restrictionist policy options that focus on limiting the human rights of migrants. For instance, Guiraudon (2000) examined the process of the 
incorporation of the European Court of Human Rights and the European Court of Justice legal norms in policies regarding post-war migrants in Europe. With these interventions, foreign residents were given improved legal status in spite of restrictive goals of migration policy after the first oil shock in the 1970s and the rise of anti-immigrant parties and sentiment.

A fifth approach, often described as a 'society-oriented' approach, highlights the state's role as a neutral 'arena' for societal interests including interest groups and political parties (Bernhardt, Krasa \& Polborn 2008). For example, instrumental in immigration policymaking is the role of public opinion, political parties, trade unions, employers' associations and NGOs. This approach tends to highlight the manner in which policymaking on immigration involves a certain amount of bargaining and compromise between these varied interests. A relatively strong economy and strong demand for labour has resulted in governments introducing more liberal immigration policies. Such a trend is largely welcomed by employers' organisations and multinational companies, if slightly less popular among workers' unions, which fear the downward pressure on wages as a result of large numbers of foreign workers. To appease public concerns on liberal economic policies, governments in the developed world, including those of northern Europe and Australia, have introduced liberal immigration programmes and temporary migrant labour schemes, while at the same time introducing tough policies on asylum-seeking migration.

The general public in these parts of the world are overwhelmingly opposed to increased immigration more generally. In order to manage the electoral politics of immigration, which is often highly emotional and not always based on rational decision-making, sharp distinctions are made between regular and irregular migrants. This is most evident in the rise of anti-immigrant political parties and, in recent years, the politicisation of asylum seekers.

France is a useful case in point. Since the 1990s, France has witnessed a rise in support for the anti-immigrant party, the National Front (FN). In the early 1990s, the new right-wing government headed by Edouard Balladur pursued draconian immigration policies that planned to stop all immigration and reduce the number of asylum seekers to a minimum. The rights of foreigners were limited and a series of internal control policies were put in place. The new immigration reforms also limited the number of asylum appeals and prohibited adjustments of status for any undocumented migrants married to French citizens. While these reforms were later modified, immigration policy in France has generally involved tougher external controls of its borders and tighter internal regulation of labour markets 
(Hollifield 2004b). The United Kingdom has also faced tough electoral and political pressures to implement liberal policies on economic migration and tough policies on asylum seekers (Layton-Henry 2004). Even though there is a need for more liberal immigration programmes, which have clear benefits for the economy, the political management of migration and asylum is difficult, with growing resentment in the local population against migrant communities (Ouseley 2001).

A sixth approach prominent in Europe, referred to as the 'neoliberal institutionalist' approach, argues that international institutions help build consensus among diverse societal interests. This theory is becoming more relevant as the removal of borders within Europe has facilitated free trade and the movement of people. For example, there is now an extensive body of literature on the 'Europeanisation' of immigration policies within the EU (Faist 2000, 2003; Faist \& Ette 2007; Geddes 2000, 2003; Geddes \& Guiraudon 2004). Political scientists tend to refer to 'Europeanisation' when something in the national political system is affected by something at the European level (Vink 2003). However, there is much debate on the extent to which supranational institutions such as the EU can exercise influence over national policymaking, especially on immigration.

\section{Research on new types of migration}

A new and emerging area of research looks at the rapid increase in temporary regular and irregular migration across Europe and throughout Asia (Duvall 2006: Duvall \& Jordan 2003; Sadiq 2005; Ford 2006). Migrants in many parts of Europe and Southeast Asia can easily move from temporary migration status to one defined by irregularity. Terms that are frequently used by governments across the world to refer to irregular migration flows include 'illegal', 'undocumented', or 'unauthorised' migration. However, patterns of migration show a far more complex picture of migrants often caught between regular and irregular categories of migration, such as when they are waiting for court decisions on their refugee status and when they suddenly become unemployed.

In order to make sense of the different terms, Triandafyllidou (2010: 1-4) identifies several different ways of referring to irregularity. First, 'illegal migrants' are viewed as 'illegal' by governments because their actual act of migration does not comply with legal provisions of entry and residence. Second, 'undocumented migrants' are usually considered 'undocumented' because they do not have the right residence papers or necessary work 
permits. Third, 'unauthorised migrants' are considered by governments as 'unauthorised' because they have generally entered a country unlawfully, violating national migration rules and regulations. A final irregular migrant group includes those who are awaiting the outcome of a regularisation programme that offers legal status to irregular migrants, common in parts of southern Europe and Southeast Asia.

Included in the irregular migration classification are also asylum seekers who usually enter a country without documentation and then file for asylum (Triandafyllidou 2010). Asylum seekers are often desperately seeking safety for themselves and their families and are therefore often willing to risk dangerous migration channels across rough seas or mountainous borders. In countries that are party to the $195^{1}$ Convention relating to the Status of Refugees, even though most of these undocumented asylum seekers are found to be genuine refugees, they often receive a disproportionate amount of media and public attention compared to other types of irregular migrants, because they are usually perceived as bypassing legal refugee resettlement processes. The public focus on this group persists despite the fact that the global refugee population stands at around 12 million people, and the resettlement places available globally stands at around one per cent of that total (UNHCR 2011c).

Temporary regular and irregular migration flows have increased rapidly since the 1990s not only because of changing economic conditions and increasing restrictions on access to citizenship but because of long-established informal social networks that tend to facilitate irregular migration. The most obvious examples include the long history of irregular migration between Indonesia and Malaysia (Arifianto 2009; Eilenberg 2012; Liow 2006) and between Burma and Thailand, where state capacity to control long and porous borders is limited. Weak bureaucracies and widespread corruption in developing countries also provide an environment in which irregular migration is likely to flourish, leading to widespread exploitation of migrant rights and working conditions.

While Australia and countries in northern Europe have tried to export their management policies through the tightening of state borders and restricting access to national citizenship, new research from Southeast Asia and southern Europe shows that patterns of irregular migration are exceedingly complex and, in general, public perceptions do not tend to recognise this complexity. In less developed countries there has traditionally been a much higher level of irregular migration than in northern Europe and Australia, where options for legal migration are available, albeit on a strictly limited basis. In countries with long and porous land borders and coastlines, there are significant costs involved in policing irregular 
migration and undeclared employment, which means that those countries simply cannot prevent irregular forms of migration (Samers 2010). Some countries in southern Europe have preferred to regularise migrants by offering various types of amnesties. Spain, Portugal, Italy and Greece have conducted numerous regularisation programmes (see, for instance, GarcésMascareñas 2012). Similarly, in Southeast Asia, Malaysia has conducted numerous regularisation programmes in order to track the extent of irregular migration from Indonesia, Bangladesh, Burma and the Philippines (Arifianto 2009; Garcés-Mascareñas 2012).

Research since the 1990s shows that countries will generally monitor, control and restrict immigration from another country rather than encourage irregular immigration (Sadiq 2005). However, in some Southeast Asian countries, irregular migrants from particular cultural and religious backgrounds are welcomed by different sectors of the local community because of their perceived electoral benefits. For example, in East Malaysia, irregular migrants play an important electoral role. While they may not be citizens, over time irregular 'undocumented' migrants are easily able to gather enough documentation needed to vote. According to Sadiq, the political participation of irregular migrants in elections has the capacity to alter political outcomes in favour of the government. It is, therefore, in the government's interest to allow irregular migrants to acquire proof of citizenship and become eligible to vote (see Sadiq 2005; 2009).

The overlapping discourses between northern Europe and Australia (i.e. restricting access to citizenship) and southern Europe and Southeast Asia (i.e. regularisation programmes) show clearly that there has been considerable convergence in policymaking on immigration as countries in Europe, Southeast Asia and Australia respond to the enormous challenges of people movement across diverse regions. To date, most migration studies have either focused on single regions because of the enormous differences in political systems, histories and cultures, not to mention the differences in the ways that regional organisations such as the EU and ASEAN operate. Laws, policies and programmes on immigration across regions are borrowed, adapted and modified to meet the local challenges of human movement across borders involving large-scale temporary and irregular migration.

\section{Outline of this book}

The essays in this volume address the implications of regular and irregular migration flows on both national and regional transformations. They bring 
to light some of the complexities of changes that have taken place in the global environment. The essays are drawn from different disciplines and placed in a comparative framework in an attempt to unravel historical, political, cultural and legal aspects of the complexities of regular and irregular migration. The volume gives relatively equal focus to three regions - Europe, Southeast Asia and Australia. The aim of this regional focus is to shed comparative light on ways in which migration flows are understood and controlled within national and regional frameworks.

The first three chapters discuss social and political dynamics underpinning new migration flows in Europe. Kaczmarczyk, Lesińska and Okólski track old and new migration flows in Europe and introduce the idea of the 'European Migration Cycle' as a way of demonstrating the relative stability of international movements of people over time. Pietsch examines some of the political interactions between the EU and member states in developing a harmonised immigration policy. Pietsch demonstrates that nation-states are remarkably steadfast in matters relating to immigration policy, especially in relation to national sovereignty and their responses to temporary labour migrants and asylum seekers.

Countries in Europe and other Western democracies also face challenges in integrating new migrants from diverse cultural and religious backgrounds. Jupp's chapter addresses the rise in support for anti-immigration parties and a decline in support for a 'practical' model of multiculturalism in Western liberal democracies. Some of this can be explained by hostility, fear and anxiety about the increasing presence of Muslim minorities. Fears in Western Europe about being swamped by Muslim migrants from politically unstable parts of Africa, the Middle East and Asia continue to undermine support for multiculturalism in the EU and other Western democracies. Jupp reveals the risks associated with letting go of some of the major achievements of multiculturalism. Among the risks are sporadic rioting, the alienation of ethnic youth and an increase in organised crime.

In the second group of essays, the focus shifts to the Southeast Asian region. Kaur focuses on irregular migration to Malaysia, where immigration has increased significantly in the past three decades. She provides an important link in the migration flows between the Middle East and Australia. In a pattern similar to that in southern Europe, Malaysia's evolving immigration policies and practices are dominated by enforcement considerations that have shaped regional migration flows. Labour brokers and recruiters do most of the recruiting, transporting and placing of undocumented migrant workers, and many workers continue to find themselves in irregular situations and vulnerable to repatriation or 
detention. Currently, Malaysian immigration enforcement processes focus on increased screening, nationality verification processes, regularisation programmes and the expansion of immigrant detention policies. These developments have meant that fundamental international labour and human rights standards are not being met, which has done little to alleviate the general culture of powerlessness among migrant workers. In addition to this, Malaysia, like its neighbour Thailand, has trouble stemming the flows of refugees and irregular migrants crossing its borders. Neither country has legislation that provides for the granting of asylum or refugee status in accordance with the ${ }_{1951}$ UN Convention relating to the Status of Refugees and its 1967 protocol, and neither has established a system for providing protection to refugees.

The chapters by Clark and Missbach examine migration flows from Indonesia to Malaysia and vice versa. Clark examines the broad relationship between democratisation, regionalism and human rights in Southeast Asia, with a specific focus on the rights of migrant workers. The treatment of migrant workers in Malaysia, the key receiving country in the region, has become a thorn in the side of several of ASEAN's key member countries, most notably Indonesia. In the democratic consolidation era, Indonesia's domestic politics have to some extent been projected onto the regional sphere. In practice, this has led to calls for region-wide political reform and a greater concern for human rights issues, including the issue of migrant workers. This has resulted in regional tensions, especially with regard to the treatment of temporary and irregular Indonesian migrant workers in Malaysia, which, as noted above, has not upheld migrant rights and protections. Missbach's chapter suggests that, whether it is a democracy or not, Indonesia does not treat asylum seekers and refugees much better than Malaysia treats its foreign workers. Missbach examines the specific conditions and circumstances that asylum seekers and refugees face when transiting through Indonesia. Despite its enthusiastic embrace of democracy, Indonesia tends to treat its asylum seekers and refugees in a rather ad hoc manner that varies from one part of the country to another. Corruption is a key element in the equation, as is funding and political pressures from Australia, a country that would prefer to manage asylum seekers and refugees in Indonesia rather than on Australian shores, where it is much more expensive.

The final three chapters shift the focus to Australia, the final destination point of the vast majority of refugees fleeing conflict and persecution via Southeast Asia. Many of these people have made a series of long and arduous journeys from the Middle East and South and Central Asia, transit- 
ing through Malaysia and Indonesia en route to Australia. Australia, like Europe, has made numerous policy changes and amendments to legislation in order to implement a much tougher and more restrictive stance on irregular migrants. Briskman and Mason demonstrate how Australia's strident emphasis on border security puts national interests at the forefront of asylum-seeker policies. The increased provision of money for border protection agencies and remote immigration detention facilities illustrates the primary importance that Australia places on protecting its borders from those seeking safe haven, particularly after the events of $9 / 11$ and the Bali bombings of 2002. Briskman and Mason examine the 'push' factors influencing Afghan and Iraqi asylum seekers who have fled conflict and civil war in the Middle East for Malaysia and Indonesia. From there, many attempt to travel by boat to Australia with the assistance of Indonesia-based Middle Eastern 'people smugglers', who use poverty-stricken Indonesian fishing crew and boats that are barely seaworthy.

How Australia manages its borders and imposes its own policies on Southeast Asia is not unlike the present system employed in northern and southern Europe. Bilateral and multilateral agreements involving the swap of what Geddes (2000) refers to as 'wanted' and 'unwanted' migrants are becoming increasingly common. For example, there is a growing trend across Europe linking country-specific legal migrant quotas to cooperation and readmission agreements with migrants' states of origin. In the words of Joppke (2004: 382), the system of choice operates along the following lines: 'we take your legal labour migrants if you in turn help us get rid of your illegal or criminal migrants - or better still, prevent them from leaving your country'. For Italy, the critical country is Albania, which receives significant financial payments for its cooperation on illicit boat traffic across the Adriatic Sea. Parallel negotiations have taken place between Spain and Morocco (Joppke 2004). Mathew examines a similar situation in Australia where the Australian government under former Prime Minister Gillard attempted to negotiate the exchange of 800 asylum seekers arriving in Australia for 4,00o persons recognised as refugees in Malaysia. Drawing on case-law examples, Mathew shows the power of domestic and supranational courts such as the European Court of Human Rights in constraining the powers of nation-states to impose not only restrictive policies but also policies that fail to adhere to international standards. Written in a context where 'stopping the boats' carrying asylum seekers from Indonesia has become a well-worn mantra of the Australian media and politicians alike, the final chapter of this volume, by Clark and Adhuri, explores the development potential of Indonesian labour migration in the Australian fishing industry. They 
suggest that the history of Indonesian migration flows across the waters of northern Australia in the nineteenth and twentieth centuries holds little sway with the Australian government as it cracks down on Indonesian illegal fishers and boats of asylum seekers, usually crewed by Indonesians.

This volume begins by engaging with some of the older academic debates on integration and multiculturalism, but in a different social context with new challenges, such as the increased hostility towards Muslim migrants in the West after the $9 / 11$ terrorist attacks. In response to fears of terrorism and a globally competitive market, governments in the three different regions explored in this volume have tightened their restrictions on asylum-seeking migration as a broad national security measure and increased temporary migration in response to the ebbs and flows of the market. Across East and West, we see similar national and regional responses to new migration flows, all of which involve a failure to implement practical integration policies designed to facilitate migration processes and long-term settlement, provide access to national citizenship, and the lowering of human rights standards for temporary regular and irregular migrants, particularly for those desperately seeking asylum.

This book emphasises the difficulties that arise when developed countries impose solutions on neighbouring poor countries. For example, when Australia's Gillard government approached the East Timor government in 2010 with a regional framework that would involve the processing of asylum seekers in East Timor, the Timorese were dismayed. The Indonesian government also weighed in on the issue, expressing strong concern to East Timor about Ms Gillard's proposal. The fear was that it could attract many more asylum seekers to Indonesia in order to access the new processing centre. Similarly, leading Indonesian politicians and diplomats expressed a great deal of concern in mid-2013 over a policy proposal from a major political party in Australia that would have involved Australian naval authorities detaining Indonesian-flagged boats of asylum seekers on the high seas and then 'turning back the boats' into Indonesian waters. Besides the potential for large losses of life associated with such a dangerous operation, the threat to Indonesian territorial sovereignty was of serious concern to the Indonesian authorities. The controversial 'turn back the boats' policy, like the failed East Timor and Malaysia proposals before it, was quietly dropped soon after the opposition party in question formed a new coalition government under the leadership of Prime Minister Tony Abbott. These are just a few examples that illustrate that both East and West have a long way to go before effective transnational cooperation can occur, let alone the establishment of a truly regional solution. What is needed is a broad cultural and political 
shift in response to the needs of the millions of people on the move through regular and irregular migration channels.

The author expresses her sincere thanks to Hans-Dieter Klingemann for providing encouragement and assistance and Philomena Murray and James Jupp who read and commented on an earlier version of this chapter. Any remaining errors are the author's sole responsibility. 


\section{$2 \quad$ Shifting migration flows and integration policies in Europe}

An overview ${ }^{1}$

Pawet Kaczmarczyk, Magdalena Lesińska \& Marek Okólski

\section{Introduction}

Post-war Europe has faced the challenge of transforming from an emigration to an immigration region. This process has occurred at different times in different parts of the continent. Southern European countries have followed the northern ones, whereas the issue of when and how the transformation will be noticeable in Central and Eastern Europe remains an open question. This transformation has had a powerful impact on every domain of the social, political and economic realm of states receiving migrants and of Europe as a whole - on its demography, labour market, welfare, politics as well as social and ethnic relations.

The last two decades were a time of dynamic political change within continental Europe, symbolised by the fall of the Iron Curtain and the development of the EU. The EU's development was a crucial factor in building a new European migration space, both as an institutional regime within the EU's legal and regulatory system and as migration patterns to and within the EU. It must be noted that what can be regarded as the European migration regime is something absolutely unique and distinct, with no comparison in the contemporary world in terms of scale or legal and institutional framework.

The aim of this chapter is to look in a multidisciplinary way at contemporary Europe as a migration space. The first section briefly introduces the concept of the 'European migration cycle' and presents the change in migration patterns within the continent and its impact on particular countries. The logic of the free movement of labour was a fundamental pillar of EU development. Understanding the dynamics of migration in Europe is therefore crucial, as it has economic ramifications. The influence of new

1 An earlier version of this chapter, entitled 'New Patterns of European Migration: A Broad View from a Multidisciplinary Perspective', was published in the ANU Centre for European Studies Briefing Papers, August 2012, Volume 3, Number 10. 
migration flows in contemporary labour markets and overall economic growth is examined in the second section of the chapter. In the final section, we examine the political dynamics of migration in Europe by looking at issues of integration and multiculturalism.

\section{Old and new patterns of migration in Europe}

It might be argued, from the long-term perspective using the European migration cycle (Okólski forthcoming), that a major feature of present migration in Europe ${ }^{2}$ is the shift that almost all countries seemed to undergo, namely from 'old' to 'new' relative stability of international movements of people. The transition from 'old' to 'new' involved two principal phenomena: 1) generally increased international mobility and 2) a reversal of the migration balance from negative to positive (from migrant-sending to migrant-receiving status). European-style modernisation and one of its integral aspects - demographic transition - were among the root causes of systematically growing population movements and ultimately the transformation of individual country 'status' from net emigration to net immigration. This transformation can be best understood in terms of a 'migration transition'.

From the medium-term perspective, it seems clear that the migration transition did not occur in the same period in all European countries. Moreover, not all countries changed their migration status easily and under similar circumstances. The pioneering country was France, followed in the third quarter of the twentieth century by the majority of northwestern European countries. After approximately two decades, the migration status was transformed in four southern countries (Greece, Italy, Portugal and Spain) and among the northwestern latecomers (Finland, Iceland, Ireland). Finally, the beginning of the 21st century is witnessing a similar change in some central-eastern countries (the Czech Republic, Hungary and Slovenia). Cyprus is also now experiencing the change. According to their current experience with the inflow of foreign citizens, the three groups of European countries might be called, respectively, 'mature', 'new' and 'future' immigration countries.

In the short term, migration processes differ significantly across countries (both within each of the three groups and among the three

2 In this text, when we refer to Europe we have in mind the EU member states and those countries that are in some way formally associated with the EU. 
groups) and are sensitive to shocks in the social milieu of an national and international nature and to country-specific policies. The effect of ongoing economic turbulence on migration flows can be used as an illustration. Some countries immediately encountered a deep decline in the inflow of migrants (e.g. Spain, the Czech Republic, Italy and Ireland); in some others, almost no reaction was noted (e.g. the United Kingdom, Germany, France, Sweden and Austria); while in other countries, inflows of migrants strongly increased (e.g. Portugal and Denmark). ${ }^{3}$ Notwithstanding these differences, the population of Europe has already acquired the major properties of a migrant population. Of all those in the world who are foreign-born, 34 per cent live in Europe (2o per cent in the EU). Of all residents of the EU, according to the 2008 Eurostat database, 19 per cent are either not EU citizens or were born abroad or had parents or grandparents born abroad, and an additional 11 per cent are EU citizens who are EU citizens who had emigrated and have returned, or are citizens with a foreign spouse.

In addition to this rather broad description of the present pattern of migration in Europe, six of its distinctive features might help in understanding its essence. First, current migration flows to and from nearly all countries are embedded in the centuries-long common history of Europe, in important events and landmarks such as major wars and famines, revolutions and technological breakthroughs, and, last but not least, overseas expansion. Secondly, a number of clusters of neighbouring countries display particularly strong intraregional interdependencies and, in fact, form migration mini-systems (e.g. Luxembourg and its three surrounding countries, Belgium, France and Germany; the British Isles; the Scandinavian countries; the Balkan countries; and pairs of countries, such as France and Italy or Germany and Poland). These mini-systems are characterised by lasting and intensive flows of people and their rich diversity.

The third feature - the culmination of the recruitment of migrant workers - links much of the present with the 1950s and 196os, when non-communist Europe was sharply divided into migrant-receiving and migrant-sending countries and many current strong immigrant communities and migrant networks were set up. At that time, the international movement of people was unequivocally perceived as beneficial and highly desirable. Many of the migratory directions, channels and routes established in those years continue today, even though the forms of flows might have changed.

3 This illustration draws from the Eurostat database on new immigrant registrations and refers to 2008 data relative to 2007 . In the first group, the change was in the range $-24 \%$ to $-43 \%$, in the second $-5 \%$ to $+5 \%$, and in the third $+54 \%$ and $+42 \%$. 
Fourth, European migration plays a vital and indeed increasingly important role in offsetting the deficit in the natural increase of the population and in decelerating the ageing of the population. For decades now, the demographic sustainability of several countries, most notably Germany, has been upheld by strong immigration, with a highly positive migration balance.

A large majority of European migrants come from relatively well-off countries, and this fact constitutes the next feature. In 2008, around 73 per cent of the total inflow to the EU arrived from countries identified as highly developed' in the United Nations Development Programme's classification based on its Human Development Index (as refined in 2008), countries whose share of the total world population was only 30 per cent. A little more than half of the migrants were citizens of other EU countries or returning citizens, and only 10 per cent originated from 'less developed' countries, whose populations comprise 22 per cent of the total world population.

Finally, typical for Europe is the relatively high propensity of its population to emigrate, usually irrespective of whether the migration balance of a given country is positive or negative. In 2008, approximately 2.3 million residents of EU countries were registered as emigrants, meaning that there were 60 emigrants per 100 migrants. In some new EU member states, such as Poland and Romania, the number of emigrants is sizable and far outnumbers the inflow of people. A high emigration volume (and rate) is also typical of renowned immigration countries such as the United Kingdom.

After the dismantling of the communist system in Europe and particularly after the most recent enlargements of the European Union in 2004 and 2007, sizable flows of labour and also of students, entrepreneurs and family members from Central and Eastern Europe to the 'old' countries of the European Community became a new and overwhelming tendency. Out of the 3.8 million migrants recorded in 2008, more than one million originated from the former European communist countries. Central and Eastern Europe (CEE) member states of the EU-27 accounted for around 60 per cent of intra-EU population movements (2o per cent of all inflows), while the share of non-EU post-communist countries (notably Albania, Ukraine, Russia and Moldova) in immigration to the EU was also significant (6-7 per cent). ${ }^{4}$ In addition, citizens of CEE countries were highly represented among other categories of migrants, such as short-term circular migrants

4 In 2008, the top ten source countries of migrants to or within the EU were Romania, Poland, Morocco, China, India, Bulgaria, Germany, Albania, Ukraine and Italy. 
(seasonal workers in particular) and irregular migrants (usually overstaying 'tourists').

In contrast to the period before 1974, when the inflow of temporary migrants (guest workers) predominated, and the years between 1974 and 1988 , when settlement migration with the purpose of family reunion was prominent, new patterns of migration flows in Europe were characterised by irregular migration patterns involving a diversity of migrant activities and strategies. Two forms of population movement emerged: incomplete migration and liquid migration.

Incomplete migration refers to the trans-border circular mobility of citizens from CEE countries originally as a response to their limited freedom of international movement and, especially, their restricted access to the labour markets of the more developed countries in the West. The major form of international movement available to citizens of CEE countries was tourism (in fact, 'false tourism'), and its main cause was the East-West differences in wage rates and prices of consumer goods. Since wages were much higher in Western countries and prices much lower in CEE countries, it became rational and highly profitable for travellers from the East to earn money in the West and spend as much of it as possible in their home countries. The 'incompleteness' on the one hand involved a lifestyle of commuting for work, but on the other hand embodied a syndrome of transnationality, social ambivalence and a split life (earning money in one country and having a household in another) for migrants.

In view of the above-mentioned restrictions, the intensity of incomplete migration flows is strongly related to the passport policies of individual CEE countries, whereas the duration of stay in receiving countries depended on tourist visa policies. Generally, incomplete migration involves a short stay and various irregular economic activities (e.g. petty trade, informal employment) in the host countries. The citizens of Poland pioneered this form of mobility in the 1980 s when, compared to citizens of other communist countries at the time, they already enjoyed quite a high degree of freedom of movement as tourists. In the 1990s, when CEE population flows increased, incomplete migration came to be the main form of mobility in several countries of the region (e.g. Bulgaria, Poland, Romania, Ukraine). After 2004, this form of immigration ceased to be popular in these countries, especially Poland, since accession to the EU granted them free or more liberal access to the labour markets in the West.

At about the same time a new form of mobility emerged - liquid migration - which had three major causes. One cause was the IT-based revolution in mass communication, coupled with the development of a cheap and 
effective transportation network. Another was the substantially increased mobility of people in CEE as a result of the far-reaching and comprehensive social change ignited by the transition to liberal democracy and the market economy. The last major cause was the high demand for labour in the rich economies of the EU, which instantly or gradually opened their labour markets to citizens of newly incorporated EU member states between 2004 and 2011. Consequently, this form of mobility is most typical of migrants originating from the eight CEE countries that joined the EU in 2004. Liquid migration is characterized by high volatility. It differs from earlier forms of large-scale migration in Europe with respect to six major aspects. First, it is by and large temporary and hence rarely leads to permanent settlement and full integration. Second, the predominant motive of migrants is economic - specifically gainful employment or improvement in their professional career. Third, migrants are as a rule fully documented throughout the migration process or at least possess a work permit. Fourth, migrants do not necessarily follow traditional routes or aim at traditional destinations, choosing new receiving regions and countries and moving between multiple destinations. Fifth, it represents a first-generation pattern of migration in which migrants are usually single and follow individualised strategies. And sixth, liquid migrants' aspirations and behaviour are intentionally unpredictable as they prefer to keep various options open. In general, liquid migration involves a high degree of unpredictability, flexibility, temporariness and circularity. In addition, because of these characteristics, it often fails to meet the basic criteria for migration that are in official use, which makes liquid migration to a large extent invisible.

\section{European migration: An economic perspective}

\section{Immigration to Europe and demography}

After several decades of an almost continuous inflow of migrants, mostly driven by the demand for migrant workers in the 1950s and 196os, the stocks of foreign-born people in Europe reached such high levels by European standards that a new wave of discussion on migration in Western European countries has emerged. In the late 1980 s and 1990s, anti-immigrant rhetoric escalated, driven by a spectacular increase in the proportion of foreign-born in the total population. The response of most Western European governments was to attempt to apply stricter control over the inflow of newcomers, particularly asylum seekers. These phenomena can be easily summarised 
by two concepts that have been continuously present in the public debate on migration since then: 'zero immigration policy' and 'fortress Europe' (Castles \& Miller 1993).

Paradoxically, the 199os brought a new, important issue into the immigration debate. Contrary to previous expectations, such as those represented by the activity of the Club of Rome, the dynamics of demographic change made it clear that the future of European societies would be dramatically shaped by the ageing of their populations. The projected increase in the share of the elderly (who are economically inactive) in the population and a decrease in related labour-market support ratios raised the question of potential political responses to these changes. One of the commonly discussed issues is so-called 'replacement migration', a potentially positive impact of immigration, which is persuasively supported in the UN report on migration's impacts on demographic structures (UN 2001). On the basis of detailed forecasts, the report's authors projected a severe decline in the population of most of the well-developed countries, accompanied by significant changes in the age structure and labour-market support ratios. Replacement migration was then analysed as one of the possible remedies. However, considering recent trends in migration and our knowledge of migrants' behavior including expectations regarding migrants' fertility, immigration does not emerge as a long-term solution to the demographic problems of the developed world. For example, extremely high and constant inflows of migrants would be needed to maintain the ratio of people of working age to those not of working age at a constant level. This is simply not acceptable either from a social or political point of view.

Nonetheless, even if replacement migration remains just a vague concept, an inflow of newcomers may serve as a source of demographic dynamism in the short or medium term, resulting in a serious impact on the labour market. According to OECD data, net migration constituted a significant portion of the total population change in most EU countries, especially in the new immigration magnets such as Italy, Spain, Portugal and Ireland (OECD 2011). Assuming zero net migration, most of the EU member countries, with the exceptions of France, Ireland and the United Kingdom, will experience a severe decline in working-age populations over the coming decades. As Fargues (2011) shows clearly, immigration is not the only solution. While an inflow of migrants will boost labour-market support ratios, in the longer term the ageing of the foreign-born will cause a further rise in the number of elderly. It is, nevertheless, one of the necessary components of the policy mix in addressing demographic change in Europe. 


\section{Foreigners and the EU labour market}

As already pointed out, during the post-war decades, migrants became a structural component of most EU labour markets, accounting in many cases for at least 10-15 per cent of the total labour force. As a result, migrants' participation in the labour market became one of the most important issues in the public debate.

Interestingly, in most cases the role and influence of foreign labour are presented in a highly stereotypical and controversial way. Commonly expressed beliefs include the belief that migrants compete with native workers in the domestic labour market and thereby reduce the number of jobs available for native workers, increase the risk that one will become unemployed, and create downward pressure on wages and workplace standards (so-called social dumping). Consequently, migrants are routinely blamed for any negative swings experienced by the EU economies. This set of beliefs is widespread in the media and is more often used by populist or right-wing parties, particularly since the global economic crisis began in 2008.

However, such a standpoint is clearly incoherent with both economic theory and empirical evidence. Regarding the first point, most economic models describing the situation and the adjustment mechanisms of the labour market question the negative impact of newcomers. In other words, only a very basic model (that assumes perfect elasticity and homogeneity of the labour-market) supply shock in the form of an additional inflow of foreign labour would project a decrease of wages. Based on these assumptions, there would be no unemployment and the total effect of immigration would be absorbed by a decline in the wage level. In more advanced approaches, the net outcome of immigration is strongly conditional on issues such as the structure of the labour market, particularly the existence of the so-called primary and secondary sectors (Piore 1979), market rigidities (e.g. a state intervention in the form of a minimum wage), and complementarity/ substitution between the native and the foreign labour force (Bauer \& Zimmermann 1999). Additionally, such effects as job creation driven by the migrants' consumption or by the emergence of an ethnic economy should be taken into account.

A large number of empirical studies related to the US labour market (Borjas, Freeman \& Katz 1996; Card 2004) show that the impact of migrants on the employment opportunities of native workers is moderate or negligible. The 'Mariel flow', a massive inflow of Cuban migrants to the Miami area recorded in 1989, is presented as one of the best examples. As clearly 
shown by Card (1990), even such a massive supply shock, which amounted to around 7 per cent of the labour force, did not influence the local and the regional labour market in a negative way, apart from the effect on the Cubans who suffered due to increased competition. In most cases, however, clear adverse effects on vulnerable groups of native workers, such as the young or poorly educated, were noted, which makes the whole picture more complex.

European labour markets are usually described as far more rigid and less flexible than labour markets in the United States. Nevertheless, even in this case, most available studies provide similar results to those presented above. Two such studies are summarised here. Bauer and Zimmermann (1999) concluded on the basis of a simulation that, in the case of the German labour market, the inflow of foreign labour brings gains for the whole economy and that the sectoral effects strongly depend on the structure of the newcomers. Interestingly, the net gain for the German economy was positive whether the newcomers were low-skilled or highly skilled, but more positive in the case of low-skilled immigration. The effect is to be explained by the complementarities between relatively better-educated native (German) workers and poorer skilled foreigners entering mostly secondary sectors of the German economy. Boeri and Brücker (2000) proved that the elasticities of wages and (un)employment with respect to immigrant labour are relatively low and that the cumulative effects of the inflow of foreign workers are small and insignificant, with the exception of the already mentioned sectoral effects.

\section{Immigration and the welfare state}

Among the wide range of issues related to immigration and its economic effects, the impact of migrants on welfare systems is probably the most controversial and can, to some extent, be explained by the continuous crisis of European welfare models. Migrants are commonly blamed for relying on public welfare and social services and for being a burden on state budgets. Moreover, this kind of belief is commonly used by policymakers as they develop migration policies. Ireland and the United Kingdom, for example, seriously restrict or delay access to social benefits for the citizens of those countries that joined the EU in 2004, as noted in the next section of this essay.

Unfortunately, the empirical studies that are available provide mixed results for both the United States (UNDP 2009) and European countries, particularly Germany (Bonin 2002, 2006; Riphahn 2004; Castronova, Kayser, Frick \& Wagner 2001). The Scandinavian countries and the United Kingdom 
represent two opposite examples. In the first case, most of the available studies document a relatively larger scale of net welfare consumption by migrants than by natives (Storesletten 2003; Hansen \& Lofstrom 2003, 2009; Nannestad 2004). Available data for the United Kingdom show rather positive and significant contributions of migrants to the treasury and net fiscal gains for the British economy, particularly in the post-accession period (Gott \& Johnston 2002; Pollard, Latorre \& Sriskandarajah 2008; Dustmann, Frattini \& Halls 2010).

The general conclusion, however, is close to those presented in the previous section. According to available empirical evidence, the net fiscal impact of immigration is small or moderate, in most cases oscillating between - 1 to 1 per cent of the receiving country's GDP, and thus can hardly explain the blame being placed on migrants. What is more, a comparison of the fiscal effects of the migration inflow in countries such as the United Kingdom and the Scandinavian countries suggests that the net impact depends on a complex set of factors including the structure of immigration, the efficiency of integration into the labour market and, primarily, aspects of the welfare regime itself, such as the generosity of the system which may lead to welfare dependency. Paradoxically, in most cases, the blame for the problems is put squarely on migrants rather than on market failures or the inefficiency of the welfare system in receiving countries.

\section{EU enlargement as a 'natural experiment'?}

The thoughts presented above suggest that the recent debate on immigration in Europe is hardly based on a solid theoretical background or empirical evidence. On the contrary, most available studies emphasise the potential positive impacts of migration inflow in terms of the labour market, the welfare state and demographic structures.

Against this background, the last two EU enlargement rounds (in 2004 and 2007) may serve as a perfect example of previously expressed ideas and as a kind of 'natural experiment'. Importantly, they were unprecedented for several reasons. Firstly, the differences in income levels and living conditions were perceived as being much larger than was the case for previous accessions, particularly in the 1980 s when Greece, Spain and Portugal joined the EU. Secondly, all the new member countries were still in the process of socioeconomic transition and some of them had faced serious barriers to mobility in the past and had not, therefore, experienced massive emigration prior to EU accession (Kahanec \& Zimmermann 2009). Thirdly, the scale of change matters: the 2004 and 2007 enlargement rounds increased the 
number of EU citizens by around 25 per cent, as compared to the 20 per cent increase in the 1980 .

Prior to 2004, all the above-mentioned factors led to a broad-based scientific and political debate on future migration from the region and, as a consequence, to a situation in which most of the EU-15 countries opted for the introduction of transitional periods (up to seven years as applied by Austria and Germany), which seriously restricted the access of citizens of the new EU member states to EU labour markets. As already mentioned, even in the cases of Ireland, Sweden and the United Kingdom, which opened their labour markets immediately, access to social welfare remained seriously restricted. Similar but much stricter solutions were applied when Bulgaria and Romania joined in 2007, when most EU-25 countries adopted transitional restrictions on the free movement of workers, even though most studies predicted the rather negative impact of transitional measures.

The years immediately following enlargement saw an unprecedented increase in the scale of emigration from the new member states. According to estimates based on European Labour Force Survey data, the number of foreign residents from the EU-8 countries (Czech Republic, Estonia, Latvia, Lithuania, Hungary, Poland, Slovenia and Slovakia) in the EU-15 rose from around 900,000 in 2003 to more than 1.9 million in 2007 (0.5 per cent of the receiving countries' population as compared to 0.2 per cent in 2003). This also means that there was a significant increase in the scale of annual flows (250,000 per year) as compared to the pre-accession period (averaging 62,000 per year from 2000 to 2003). The biggest outflows were from Slovakia, Lithuania, Poland and Romania (Brücker et al. 2009). According to estimates presented by Fic et al. (2011), the proportion of emigrants in a sending population in 2009 was as high as 1.8 per cent in the case of the EU-8 and 6.3 per cent in the case of the EU-2 (Bulgaria and Romania). The highest outflows were from Romania (7.3 per cent), Lithuania (4.2 per cent), Bulgaria (3.4 per cent), Latvia (2.5 per cent), Poland (2.4 per cent) and Estonia (2.3 per cent). In absolute terms, the largest stock of emigrants was from Poland and Romania.

However, the overall increase in migration after 2004, even if significant in absolute terms, remained moderate when compared to the population sizes of both the sending and receiving countries. The only exceptions were Ireland and the United Kingdom (4 per cent and 1.2 per cent of the receiving populations respectively), which absorbed migrants mostly from the EU-8 countries, and Spain and Italy (1.9 per cent and 1.5 per cent respectively), which became immigration magnets for the citizens of Bulgaria and Romania (Fic et al. 2011). Nevertheless, the whole process was exceptionally 
dynamic and, particularly in the Anglophone countries, completely changed their immigration structures. Within only three or four years, migrants from the new member states became the most important immigrant group in the United Kingdom and Ireland. Significant changes were noted in many other countries, including Spain, Italy and the Netherlands. In contrast to the past, new migrant flows from the region tend to be male and strongly work-oriented, with labour migrants the vast majority of the total flow. They are also young and relatively well-educated (Kaczmarczyk \& Okólski 2008).

As noted in the previous section, the recent flows from CEE can be categorised as 'liquid migration' (Black Engbersen, Okólski \& Pantiru 2010), given its transitory, transnational and temporary character. The relatively large scale and particularly unprecedented dynamics of the post-accession flows raised questions about the effects of this phenomenon for both sending and receiving countries. In the context of this chapter, the impact on the receiving country is of particular importance. Most of the available studies document a relatively efficient matching process between temporary workers coming from labour-redundant transition countries and the labour markets in the 'old' EU member states, with their permanent demand for labour, especially for low-skilled migrants. The post-accession migrants staying in Western European countries, tend to have higher labour-market participation rates and lower unemployment rates, compared to the native labour force as well as the labour force in the sending countries. Because of their skill levels, the post-accession migrants are seriously overrepresented in occupations that require low and medium skill levels, filling critical gaps in the labour market (Kahanec \& Zimmermann 2009; Dustmann, Frattini \& Halls 2010).

The macro-level studies available shed new light on the aforementioned debate concerning the developmental impacts of migration. Brücker et al. (2009) analysed the impact of EU-8 migration between 2004 and 2007 and concluded that the receiving countries gained significantly from the massive post-accession flows. However, it seems that the impact has been negative or neutral for sending countries. All in all, the impact on GDP, GDP per capita, unemployment and wages was rather moderate in the short term and negligible in the long term. The more recent study provided by Fic et al. (2011)-which covers the period 2004-2009 and therefore also the initial phase of the recession - shows that Ireland and the United Kingdom, which opened their labour markets to newcomers from Central and Eastern Europe, gained the most from post-accession migration. The gains for the EU-15 economy were moderate but also positive.

The 'natural experiment' of the EU enlargement may serve as evidence that mobile Europe is not just a hazy concept. Hundreds of thousands of 
'new Europeans' departed on their migration journeys looking for better jobs and living conditions. The structure of the process shows that recent intraEuropean migration is mostly demand-driven. Migrants are filling gaps in highly segmented labour markets, and overall the receiving countries benefit more than the sending countries.

\section{How have nation-states and the EU responded to the diversity of migration forms?}

As stressed earlier in this chapter, as a migration space, Europe has faced remarkably diverse forms of migration flows in recent decades. Massive post-war migration constructed a new reality that the nation-states had to confront - one that was connected not only to demographic and social change but also to a fundamental transformation of the understanding of national culture, ethnicity and citizenship.

Immigration brings a variety of challenges - to demography, the labour market, ethnic composition, social structure, national politics. Whereas a population, an economy, a legal system and even politics are able over time to adapt to some extent and deal with immigration, its impact on the social and cultural life of a community is probably its most controversial aspect. It results in serious tensions, especially in the daily interactions between migrants and longer-term citizens of host societies.

Nation-states have responded to cultural pluralism with various strategies to manage diversity. A wide range of policies have been implemented over time, including assimilation and segregation at one end of the spectrum, and integration and multiculturalism at the other, with many other possibilities in between. For decades, a common policy was to exert pressure on minority groups - both settled ones and newcomers - to assimilate and become absorbed into the dominant national culture. Such a policy was justified by the superior interests of national unity and social stability. Post-war immigration, together with other global processes such as decolonisation, brought significant change in the area of ethnic relations. Since the 1970s, changes in the states' approaches towards acceptance of cultural and ethnic diversity have been visible. The pioneering state in Europe was Sweden, where the government began implementing its own multicultural policy in 1975. Other countries needed more time to recognise the facts and officially accept the multicultural diversity of their own societies: the German government, for example, announced that it is a multicultural country in 2000. 
As a policy, multiculturalism is based on the view that the diverse cultural traditions of ethnic and religious communities should not only be recognised but also actively facilitated by the government. The government should provide institutional structures to protect and develop the cultural diversity of migrant communities by supporting education in other languages, fostering awareness of cultural diversity through the media and the school curriculum, or supporting the translation of official documents into the languages of minority groups.

Most European countries developed their own 'philosophies of integration' based on differing traditions, concepts of community, citizenship and nationhood (Brubaker 1989; Favell 2001; Ireland 2004). As a result, a variety of integration policy models directed at migrants emerged. In very general terms, for instance, the French model of integration could be described as a 'republican' one. It sees integration as a process by which the ethnic differences would disappear as migrants are integrated into the community of French citizens via expansive naturalisation. The German model represents a 'social' model of integration where the labour market and welfare-state membership were recognised as the basis of integration. The model implemented in the United Kingdom seems to be the closest to a classic 'multicultural' model. Based on the concept of a 'community of communities' where cultural and ethnic diversity is recognised as a value, the UK's policy stemmed from colonial traditions and the idea of a commonwealth. Understanding the logic of any individual country's integration policy requires looking deeper into the history of particular countries, traditions and ideas of community, nationhood and citizenship and taking into account the unique national context in which immigration emerged.

The contemporary politics of migration and integration in Europe cannot be understood without accounting for the dynamics of both migration and mobility and the role the EU now plays in managing both. Immigration has always been a sensitive issue and some countries were reluctant to cede their authority in the management of human flows to a supranational level due to their strong, traditional approaches based on national sovereignty. Although there is evidence of policy convergence in the EU - shared objectives, common legal instruments and a highly developed decision-making process - this does not mean that there is a single common EU approach to managing migration. The harmonisation process is noticeable, particularly in domains such as external border protection, visa policy, the asylum regime and the response to irregular forms of migration.

Europe is not a consolidated migration space; its rich diversity in terms of the migration profiles of particular countries has to be taken into account. It is 
difficult, even impossible, to compare countries such as the United Kingdom, France and Germany, which have large populations of migrants and a history of immigration over several generations, with Poland and Hungary, where less than one per cent of the population are permanent migrants. Whereas the United Kingdom, France and Germany have long-standing traditions of immigration and engage in intensive debate about how to shape a multicultural community, Poland and Hungary are at the beginning of the transformation into emigration/immigration countries and have small migrant inflows, which means that immigration - let alone integration and multiculturalism - is rarely the subject of public or political debate. Moreover, diversity within a country may also be noticeable. There can be a gap, sometimes large, between policies implemented in one region or city and another, because the nature of the inflows and the social and economic profile of migrants may differ in peripheral regions from those in the capital city. In the more decentralised countries, such as Germany or Spain, local units are able to develop their own approach to implementing an integration policy.

In such a multilevel model of implementing migration policy, and given the territorial dispersal of migrants, the principle of subsidiarity emerges as a solution. This assumes that political decision-making should be as close as possible to the governed to ensure that the decisions are beyond dispute and respond well to their needs. The EU level of government provides the guidelines, a set of basic concepts and general rules to be implemented through their transposition by the member states into national and regional policies in an agreed manner (via the so-called open method of coordination). Below, we outline the main characteristics of EU migration and integration policies:

- The highly developed free-movement framework for EU citizens is the most visible example of what the European Union project has achieved. Free movement, initially introduced for workers, was provided in 1957 by the Treaty of Rome and was strictly related to the economic impetus underpinning European integration. In time, third-country nationals (TCNs) and refugees were included in the free-movement framework. That was the beginning of the development of the EU's migration regime, institutionalised further in the Amsterdam, Nice and Lisbon Treaties.

- The EU's migration and integration policy is firmly embedded in the single-market concept: in order to allow the member states' economies and labour markets to become one single market, EU policy had to be extended to the area of migration and integration. This almost purely 
economic orientation is also reflected in the debate at the EU level, where the cultural component is almost absent.

- The EU prioritises anti-discrimination legislation. The normative fundamentals are created by two directives introduced in 2000 - the Race Equality Directive and the Equal Treatment Directive, both aimed at combating discrimination on the grounds of race and ethnicity in employment, social protection and the provision of services - and the 2003 Directive on the rights of long-term residents, which are extended to legally resident TCNs after five years of legal residence. These documents play a crucial role. They are binding and must be implemented by all member states. Anti-discrimination legislation is well developed at both the EU and national levels. However, its translation into daily practice remains a great challenge.

- The EU formally defines the concept of integration as a dynamic twoway process of mutual accommodation by migrants and residents of the member states (European Commission 2005). Managing integration is thus the shared responsibility of both the migrant newcomers and members of the host society. As agreed by the EU Council in 2004, the Common Basic Principles for Immigrant Integration Policy in the EU introduced a socioeconomic approach to integration and underlined the primary role of education, work, housing and health as the areas of successful integration.

- The EU itself does not deliver integration; it provides a rights-based framework that enables mobility and the portability of rights and entitlements within a single market area. EU legislation does not change the content of national integration policies, but provides an important context in which they are developed. This context is a common general legal and political framework, based on an obligatory acquis and a collection of recommendations and best practices which all EU countries should follow, through the open method of coordination mentioned above. In other words, EU directives provide relatively general pointers to encourage a degree of policy convergence.

Among the main challenges mentioned in EU documents concerning the integration of migrants, the most important include prevailing low employment levels of migrants (especially among migrant women), rising unemployment and high levels of 'over-qualification', increasing risks of social exclusion, gaps in educational achievement, and public concern about the lack of integration of migrants. Given these challenges, the EU has proposed that member states' actions should focus on three main areas: 
1) integration through participation (in the labour market or in education and training); 2) actions focused on the local level (addressed particularly to disadvantaged urban areas and aimed at improving multilevel cooperation between different levels of governance); and 3) the involvement of the countries of origin (to prepare migrants for integration before their departure, to support contacts between diaspora communities and their countries of origin, to promote circular migration, and to enable the migrants' temporary or definitive return process) (European Commission 2011a).

European migration and integration policies seem to develop in a kind of sinusoidal way. In times of economic growth and social stability, governments are more willing to implement liberal legislation and societies are more willing to accept newcomers. This is not the case in times of economic downturn and insecurity, as is currently the case in Europe and the rest of the world, when voices critical of immigration and multiculturalism become more prominent. Within a few months of the end of 2010 and beginning of 2011, leading politicians such as German Chancellor Angela Merkel, French President Nicholas Sarkozy and British Prime Minister David Cameron added fuel to the debate against multiculturalism in Europe by making very forward and strong statements. There are two main themes shaping the debate on immigration and integration in the European media and in political and public spheres. The first is that immigration is a threat to public security, and the second is that multiculturalism is contradictory to social cohesion.

The tone of the debate on the integration of new migrants has changed significantly in the last few years. The belief that multiculturalism brings positive effects to the social integrity of host communities has diminished. The prevalent fear of an external threat or a threat from already present migrants, sustained by the media and some of the political elites, has had a powerful impact on the shift towards anti-immigration and anti-multiculturalism debate. The association between immigration and security has been increasingly highlighted in the public rhetoric.

The debate on the failure of policy to secure the integration of new migrants now tends to be the main public policy concern and, moreover, is focused particularly on Muslim communities. Muslims are accused of self-segregation: they shut themselves in closed neighbourhoods and live in parallel communities in inner cities. Some commentators openly doubt that their integration is possible because the cultural differences are regarded as too pronounced. In the context of the common concerns about the erosion of social capital and the lack of social cohesion in European and other societies, it seems rather ironic that Muslims are accused of having too much 
bonding capital. Strong religious identity, a lower level of integration, the role of the traditional sharia law (as being above state law), a common fear of radicalisation, alienation and violence among Muslims, especially young Muslims, have meant that the debate around immigration and integration has become focused on the security-terrorism-Islam triad.

Recent anti-immigrant sentiment and a backlash against multiculturalism within European societies stem from frustration and concern over demographic change and increasing cultural diversity brought about by migration inflows on the one hand and the economic crisis on the other. They challenge national governments and EU bodies alike to find ways to balance the declining support of host societies for multicultural policies and the growing need to implement more effective policies that facilitate the sociopolitical and cultural integration of migrants.

\section{Conclusion}

In the last few decades, most EU countries have undergone a significant transformation from net sending areas to net receiving areas. This process, described above as the migration cycle, was deeply rooted in a broad socioeconomic context that included such phenomena as demographic transition and modernisation. As shown in the first section of this chapter, the dynamics of these processes have had a serious impact on the migration status of particular European countries and are still, to a large extent, responsible for the diverse migration profiles of EU countries.

As a consequence, Europe became a continent of immigration and the destination for more than one-third of the worldwide population of foreignborn. Nowadays, migrants constitute a significant proportion of most EU countries' total populations and labour forces. In structural terms, most of immigration can now be classified as permanent, in contrast to the migration in the period between the 1950s and the 1970s which was dominated by the short-term movement of people. Nonetheless, due to loopholes in migration policies, developments in the IT sector, new transportation opportunities and changes in the cost/benefit ratios for would-be migrants, new forms of migration appeared. The best example is so-called liquid migration, described above as being temporary, circular and highly flexible.

Because of the increased presence of new migrants in European societies, immigration has become one of the most important topics in the public debate. One of the main aims of this chapter was to juxtapose common beliefs and stereotypical knowledge with the impact of migration based 
on available empirical evidence. The studies that were cited show that an inflow of migrants does not offer an ultimate solution to demographic ageing but may help to overcome short- and medium-term shortages in the labour market. Contrary to commonly expressed and widely shared opinions, immigration to EU countries has not had negative effects on either their labour markets or their state welfare provisions. As an example of this thesis, the 'natural experiment' of the EU enlargement rounds in 2004 and 2007 was presented. This process - massive in terms of population change as well as migration flows - has turned out to be highly beneficial, particularly for those EU countries that implemented immigration-friendly policies.

Nevertheless, as clearly stated in the last section of the chapter, the inflow of new migrants confronts EU societies with a variety of challenges, including ethnic composition, social cohesion and social structures, and national politics. The effects of immigration on the social and cultural daily life of receiving communities continue to be highly controversial. This chapter looked at diverse forms and modes of migrants' incorporation into EU societies and documented in particular the rise and fall of the European version of multiculturalism, if one can be identified as such. One of the theses proposed was that EU immigration and integration policies are strongly related to swings in the European economy and thus seem to develop in a sinusoidal way. Additionally, well-developed EU countries seem to be facing a clear 'liberal paradox' (Hollifield, Hunt \& Tichenor 2008). In order to remain competitive in an increasingly globalised world, they need to open their economies to newcomers, mostly to meet labour-market needs, but at the same time for reasons of security and internal political forces, they are pushed towards stricter control of access. 



\title{
3 Public opinion towards new migration flows in Europe and the increasing role of the $\mathrm{EU}$
}

\author{
Juliet Pietsch
}

\section{Introduction}

As the European Union moves towards a common set of policies on immigration and asylum, increasing attention to public opinion on immigration suggests that public opinion matters (Anderson 1998; Dalton \& Eichenberg 1998; Franklin, Marsh \& McLaren 1994). Governments often find it difficult to reconcile public concerns about immigration with the EU project of internal free movement for EU citizens. In addition, citizens concerned about unemployment and a downturn in the economy have become increasingly vocal in pressing for more restrictive measures on policies concerning family reunification, freedom of movement, work permits and border security. In this chapter, the development of immigration policy and public opinion in Europe will be discussed in three sections. The first section discusses contemporary concerns about temporary and irregular migration in Europe since the 1990s. The second section examines attempts to build a regional response to migration policy through the development of EU legislation. These two sections provide a background to the third and final section on EU migration policy and public attitudes towards new migration flows.

\section{Migration pathways in Europe}

Immigration has been a hot issue in Europe, particularly since the late $1980 \mathrm{~s}$ and early 1990s when immigration rapidly increased in countries in southern Europe. According to Boswell and Geddes, since the early 1990s, we have seen:

- a greater intensity of migration flows to and within the EU;

- more countries affected by immigration;

- a growing role for the EU;

- new manifestations of the immigration problem, for example growing concern about irregular flows, people-smuggling and human trafficking (Boswell \& Geddes 2011: 3). 
In Spain and Italy, for instance, there has been a rapid increase in the number of migrants since the beginning of the 21st century. When Spain received an increase in migrants from neighbouring poor countries in the 1980 s and 1990s, this did not lead to high levels of racial prejudice and anti-immigrant attitudes because at the time immigration was not politicised (Boeri, Hanson \& McCormick 2002). However, by 2010, widespread anti-immigrant sentiment was reported in Spain, as the migrant population had risen from 2 to 12 per cent of the population in the first decade of the 21st century (Boswell \& Geddes 2011: 5). Cyprus, the Czech Republic, Hungary, Malta, Slovakia and Slovenia also experienced an increase in immigration during this decade. By contrast, countries in Eastern Europe including Bulgaria, Estonia, Latvia, Lithuania, Poland and Romania experienced population decline, with more people leaving than entering.

An emerging concern for many countries in Europe is the national and regional issue of irregular migration flows. In some countries in southern Europe, there is a more permissive political culture towards irregular migrants than in other countries. Spain, Greece and Portugal have been under considerable pressure by the EU community to tighten restrictions on irregular migrants. According to Gonzalez-Enriquez, when it comes to managing irregular immigration, southern Europe is viewed as a policy failure because 'irregular immigration since the late eighties has been de facto accepted as a common way of entry' (Gonzalez-Enriquez 2009: 140). For example, almost half of the migrant population arriving in the EU since 2000 registered first in Spain.

Greece also experienced a sharp increase in migrants in the late $1980 \mathrm{~s}$ when increasing numbers of migrants flowed from the Balkan region, particularly Albania. Later, in the 199os, migrants began arriving from wider Central and Eastern Europe. Greece was largely unprepared for the sudden and unexpected migrant flows, as it had few legislative frameworks in place to control and manage immigration (Triandafyllidou 2009). Immigration was considered by many in Greece to be not only a socioeconomic threat but also a serious threat to their cultural and ethnic identity. According to Triandafyllidou, 'Greece seems to have been stuck for a long time with its national interests' concerns and an overarching view that migration is an unwanted burden for the country despite developments in other European countries and at the EU level' (ibid:174). It was as recent as 1997 that Greece introduced a programme to regularise irregular migrants. After 1997, migrants could only be considered legal if they had secure employment. 
As soon as their employment contract was finished, they were no longer allowed to stay in Greece.

In general, migration policy towards irregular migrants and asylum seekers became less friendly from the 1980 s and early 1990s, as greater pressure to tighten borders made it more difficult for irregular migrants and asylum seekers to gain entry into the EU. For instance, in the United Kingdom the 1993 Asylum and Immigration Appeals Act led to a sharp decline in the number of asylum seekers granted refugee status. The Act withdrew numerous welfare benefits previously available to asylum seekers and remained the Labour government's policy throughout the 1990s. From 1997 onwards, the British government made it harder for asylum seekers to be granted special provisions to assist with their settlement. For example, the 1999 Immigration and Asylum Act replaced cash benefits with a voucher system, and special support was provisional on participation in the national dispersal scheme that was implemented to stop the influx of asylum seekers and relieve housing and social pressures in London and southeast England. Despite the gradual scaling back of welfare benefits, the United Kingdom continues to be one of the more favourable destinations for asylum seekers in Europe.

With such vast populations on the move within the EU, the need to build consensus around a common EU migration and asylum policy has increased. Border security and irregular migration are of particular concern for member states. In most EU countries, there is public resistance to increased immigration and an ongoing conflict between the economic and demographic reasons to increase immigration (Boswell \& Geddes 2011: 31). One way governments have tried to appease a restless public is to promote regular migration and emphasise the need for strict control over irregular forms of migration. Another way governments have tried to deflect anti-immigration public sentiment is to focus on migration of a temporary nature that does not offer permanent residency. These concerns have largely been reflected in the EU's attempts to harmonise immigration policy across Europe.

\section{The harmonisation of European immigration policies}

While the overall population of the EU-27 has grown, some countries in Europe are facing population decline. According to population projections, virtually all countries in Europe are expected to decrease in size. While migration may help to improve this situation, migration on its own cannot 
solve the problem facing many countries in Europe. According to the United Nations Population Division:

The levels of migration needed to offset population ageing (i.e. maintain potential support ratios) are extremely large, and in all cases entail vastly more immigration than occurred in the past ... maintaining potential support ratios at current levels through replacement migration alone seems out of reach, because of the extraordinarily large numbers of migrants that would be required (2001).

Since 2002, net immigration into the EU has oscillated between 1.5 and 2 million peryear (European Commission 2007). The process of EU enlargement has resulted in a substantial increase in labour mobility from East to West (Fic et al. 2011). While there are significant concerns for Western Europe, the more detrimental effects of the current pattern of immigration are in Eastern Europe, where population outflows to the EU-15 countries from countries such as Bulgaria, Romania and Lithuania are estimated to result in a population decline in those countries of around five to ten per cent (ibid.). Romania is particularly affected by emigration. Demand for highly skilled migrants in the EU-15 countries suggest a brain drain from Poland, the Czech Republic and Hungary. As populations move increasingly from East to West, there is a growing awareness of the need for European member states to debate and reach consensus on immigration policy. For example, in 2007, the European Commission argued that 'in a single market with free movement of persons, there is a clear need to go beyond 27 immigration policies' (2007:7).

The European Commission is formally responsible for initiating EU immigration policy by proposing new legislation to the EU Council and the European Parliament (EP). Once the Commission lodges a proposal with the EU Council and the EP, the three institutions collaborate to try and reach a consensus (Hix \& Noury 2007). The Lisbon Treaty signed in December 2009 gave the EP legislative powers equal to those of the EU Council of Ministers. In order to gain majorities in the EP, it is necessary for Members of the European Parliament (MEPs) to compromise and negotiate with MEPs from other parties until a consensus is formed. Adding complexity to the EU governance structure is the overriding value of the sovereignty of the state. As immigration policy shifts from the domestic domain to the EU level, it is to be expected that the EP and the transnational political groups will play a greater role in decision-making on immigration. However, in most member states, national party leadership controls the selection of candidates for the EP elections. National parties have often used this power to ensure that 
MEPs have political preferences similar to those of their national party leaders. For example, party leaders often issue instructions to MEPs on how to vote on important issues such as immigration (El-Agraa 2011).

Members of the EP sit according to broad political groups, which cut across nationality (Lahav 2004). The broad political groups are meant to reflect new political cleavages that respond to a shift in value systems evidenced by an increase in voter volatility and the growth in single-issue movements and non-traditional parties (Kreppel 2002; Raunio 1997). However, voting in the EP is by and large influenced by the left-right ideological orientations of the EP political groups (Lahav 2004). Evidence of this leftright divide is particularly noticeable with the recent formation of far-right anti-immigrant party alliances. For example, the growing influence of the European Alliance of National Movements (EANM) grouping is of some concern. While it cannot be formally recognised as a political group until it has the required $25 \mathrm{MEPs}$ from seven EU member states, the grouping has been able to attract EU funding even though some of the member parties are not supportive of European integration (Taylor 2012).

Since the Lisbon Treaty, the EP has gained more legal authority in migration decisions. For example, in June 2008 the EP and the Council reached agreement on the return of 'illegal' migrants (and third-country nationals who are not EU citizens) under the co-decision procedure by 369 votes to 197. The main aim of this agreement, known as the Returns Directive, was to outline EU-wide rules and procedures on the return of illegal migrants. While the EP is considered to be slightly more migrant-friendly than the Council and the Commission (Acosta 2009), expectations that the EP would stand up for migrant rights have not been met. For example, the Returns Directive adopted through co-decision attracted a great deal of criticism by NGOs because of its lack of attention to individual human rights. While migrants who are deported under this directive are afforded some protection, there is a great deal of ambiguity about who exactly are considered 'illegal' migrants. In some cases, regulations and directives allow member states to adopt higher standards, but in other cases they encourage member states to lower their standards.

\section{Negotiating public opinion and EU immigration policy}

The effect of public opinion and the growing influence of the far right impose significant national constraint on various attempts within $\mathrm{EU}$ institutions to improve conditions for migrants through new legislation. 
Increasing support for far-right anti-immigration parties in Europe reflects citizens' concerns about unemployment, lower wages, overcrowding, crime and safety, border security and identity. The radical right has emerged as a growing electoral force in Western Europe (Arzheimer 2009; Bos \& van der Brug 2010; Spanje 2010), most notably in the formation of anti-immigration right-wing parties. In fact, the populist radical right-wing parties form the most successful new European family since the end of the Second World War. They have not only increased their electoral support but have also entered national governments as part of coalitions (Mudde 2013). For example, in the 2009 EP elections, populist radical right-wing parties in Austria and the Netherlands attained a share of the vote that approached 20 per cent, and their share of the vote in six other countries exceeded 10 per cent. Voting for these parties tends to be based on fears about cultural identity and a desire to reduce the level of immigration (Rydgren 2008).

Adding to citizens' concerns about the increasing role of the EU in responding to new immigration flows is the fact that there is a low level of public support for the EU more generally. Historically, there has been little support for EU institutions, many of which have been 'perceived as unresponsive, unaccountable ... [and] ... centralising' - a perception that has led to popular distrust in transferring power from national governments to the EU level (Fella 2000: 71). There have been attempts to bring the EU closer to citizens and make it more accountable. The greater legislative and agenda-setting powers given to the $\mathrm{EP}$ are just a few examples of attempts to further democratise EU institutions. There have also been efforts to engage citizens directly through the new European Citizens' Initiative (European Commission 2011b), which is intended to provide individual citizens with access to channels of influence within the EU. All EU citizens old enough to vote can instigate initiatives and invite the European Commission to propose a law in an area in which it has the power to do so. Before, citizens had to form a citizens' committee composed of at least seven EU citizens living in at least seven different EU countries before they could propose a law.

Despite such attempts to make the EU more accountable, findings from the 2009 European Election Studies show that EU institutions' overall legitimacy continues to be weak. For example, Table 3.1 shows that only $5^{0}$ per cent of citizens believe the EU considers the concerns of citizens and less than $5^{\circ}$ per cent of EU citizens trust EU institutions. Overall, much greater importance is still placed on national institutions. For example, a higher proportion of citizens believe that it is important which party wins at national elections (68 per cent) compared to EP elections ( $5^{8}$ per cent). 
Table 3.1 Public support for EU institutions, 2009

\begin{tabular}{lcc}
\hline & \multicolumn{2}{c}{ 'Strongly agree' or 'agree' } \\
\cline { 2 - 3 } & Percentage & Number \\
\hline EU Parliament considers concerns of citizens & 50.1 & 13,552 \\
Trust in institutions of the EU & 46.8 & 12,667 \\
Important which party wins most seats at EP elections & 57.9 & 15,688 \\
Important which party wins at national elections & 68.3 & 18,483 \\
\hline
\end{tabular}

Source: 2009 European Election Study (EES) Survey $(N=27,069)$

Public support for EU decision-making on migration policy varies considerably between EU member states. Figure 3.1 shows the percentage of respondents in EU member states in 2009 who felt that EU policies on immigration had a negative influence on their country and the percentage of respondents who felt that the EU was responsible for the numbers of immigrants coming into their country. Some countries were more pessimistic than others about the EU's policies on immigration. For example, when asked whether the EU policies on immigration have had a positive or negative impact on their country, up to 46 per cent of respondents in the United Kingdom and 45 per cent of respondents in Greece expressed the belief that $\mathrm{EU}$ policies on immigration had a negative impact on their country. In terms of whether they felt the EU had full responsibility for levels of immigration in their country, 43 per cent of respondents in the United Kingdom believed that the EU had full or near full responsibility for the levels of immigration. A significant proportion of respondents in Greece (52 per cent) felt that the $\mathrm{EU}$, as opposed to their national government, was largely responsible for the levels of immigration in Greece.

By contrast, in Eastern Europe, EU policies on immigration were not seen to have such negative consequences. For example, only 14 per cent of respondents in Bulgaria, 16 per cent in Estonia and 17 per cent in Romania believed that EU policies on immigration had a negative influence on their country. In terms of future demographic impacts, the effects of EU migration policies were considered likely to be far more detrimental for sending countries than for receiving countries. Romania and Bulgaria are the two largest sending countries within the EU region where the effects of emigration were considered likely to have significant demographic consequences.

While the EU supports increasing immigration flows in the EU, in some countries there is an overwhelming consensus on the need to reduce immigration (see Figure 3.2). For example, in 2009 over 85 per cent of the population 
Figure 3.1 Perceptions of respondents in EU countries of the impact of EU migration policies on their countries, 2009

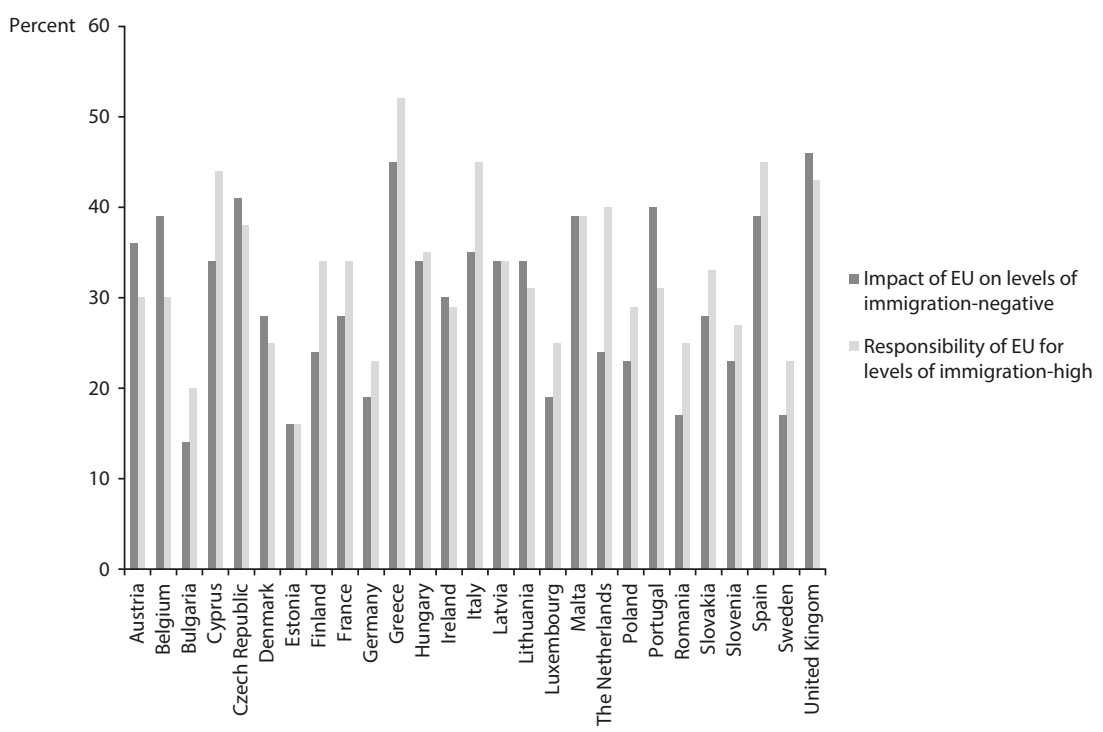

Source: European Election Study, 2009

in Cyprus, Greece and Malta and over 65 per cent of the population in the Czech Republic, Italy, Portugal, Spain and the United Kingdom said that they believed immigration should be decreased significantly. Public debate on immigration in Europe has focused primarily on concerns about employment and competition with native workers and the impact of temporary and irregular migration flows on wages (Hatton \& Williamson 2005). Those who perceive they will be most affected tend to be those in more insecure forms of employment and those who are fearful of losing their job. Lahav (2004), for instance, finds that unemployment in and of itself may not always be a significant predictor of attitudes towards immigration. Rather, what can sometimes matter more is the fear of losing one's job in a declining labour market and ending up in a situation of long-term unemployment.

The other debate on immigration focuses on the perception that migrants rely on welfare. However, this debate is not confined to the EU. Studies around the world have found that local citizens frequently perceive new migrants as a burden on the welfare system (Dustmann \& Preston 2007; Facchini \& Mayda 2006; Scheve \& Slaughter 2006). These perceptions are heightened when lowskilled or welfare-dependent family migrants dominate immigration patterns in developed countries. While the public may have concerns about the impact 
Figure 3.2 Public support for decrease in immigration levels in EU countries, 2009

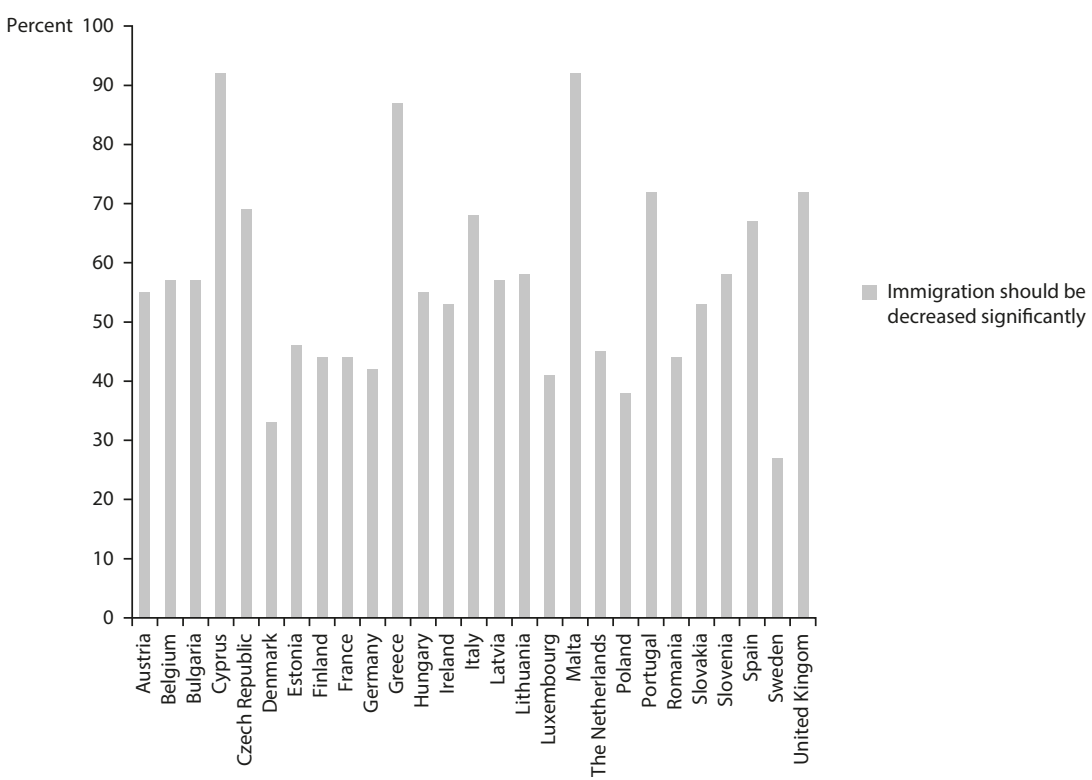

Source: European Election Study, 2009

of new migration patterns on welfare, research by accession monitoring has countered this argument by demonstrating that the fiscal impacts of migration are marginal (Sriskandarajah, Cooley \& Reed 2005). First-generation migrants may sometimes generate fiscal costs. Second-generation migrants, however, are expected to generate a fiscal surplus.

It is possible that the arrival of asylum seekers can also heighten public debate about the need to reduce immigration, but there appears to be no clear link between the arrival of asylum seekers and public opinion towards immigration levels. For example, the main destination countries for asylum seekers in Europe are France, Germany and Belgium, yet it is not in these countries that the strongest opinions towards immigration levels are expressed (Bitoulas 2012). The arrival of asylum seekers could be playing a role in public support for a decrease in immigration levels in Malta, which has had a high number of asylum applicants relative to its population (Bitoulas 2012).

Debate on immigration policies can often fuel unnecessary prejudice and intolerance. New migrants often become the target of public frustration that is more related to increasing globalisation and economic interdependence between countries. The Netherlands is a case in point. Compared with 
the rest of Europe, the Netherlands experienced more harmonious social relations during the economic downturn of the 1980s. Non-citizens gained the right to vote in local elections, and in the 1998 local elections a large number of Turkish and Moroccan candidates won office (Luedtke 2009). In addition, new subsidies and other social protection measures were provided to new migrants (Ireland 2004). However, simmering resentment has since generated increasing anti-immigration sentiment and far-right political parties such as the Party for Freedom (PVV), which is anti-immigrant and anti-Islam. Migrant workers and asylum seekers from Muslim backgrounds have become caught in the middle of the political and public debate about the collision of Western European and Muslim values (Ireland 2004).

The government in the Netherlands has called on the EU to initiate much stricter legislation on immigration. News reports in 2011 highlighted some of the Dutch government's attempts to appeal to a public concerned about EU immigration policies and high unemployment. For example, the former immigration Minister Gerd Leers of the right-of-centre Christian Democratic Appeal (CDA) opposed Bulgaria and Romania joining the Schengen Agreement. Leers expressed fears that Bulgaria and Romania were not doing enough to combat widespread corruption. However, the real issue may have had more to do with domestic concerns about a slow economy and high unemployment rates (Sniderman \& Hagendoorn 2007). Table 3.2 shows the percentage of respondents in the Netherlands mentioning, among other issues, the economy, unemployment and immigration as the most important problems facing the country in 2009. In a list of 49 issues, immigration was ranked the fifth most important issue for the Dutch population behind concerns about the economy, unemployment and the national way of life.

Table 3.2 Public perception of the most important problems facing the Netherlands, 2009

\begin{tabular}{lcc}
\hline & Number & Percentage \\
\hline 1. Economic conditions & 404 & 40.2 \\
2. Unemployment & 77 & 7.7 \\
3. National way of life (reference to patriotism/nationalism) & 74 & 7.4 \\
4. Effects of financial crisis on domestic economy & 45 & 4.5 \\
5. Immigration & 32 & 3.2 \\
Other & 373 & 37.0 \\
Total & 1005 & 100 \\
\hline
\end{tabular}

Source: 2009 European Election Study (EES) Survey 
Up to 45 per cent of the Dutch respondents felt that immigration should be decreased significantly. In response to this sentiment, the Dutch government has been at the forefront of a number of proposals to the EU for a more restrictive immigration policy. In 2012, the Dutch coalition minority government suggested changes to at least five of the EU Directives. The changes included much stricter requirements for family migration and a reduction in the issuance of work permits to people from outside the EU so that governments could focus on addressing the problem of high unemployment (DutchNews 2011a). The more restrictive immigration policy agenda in the Netherlands is seen as an attempt to maintain the support of the right wing political party PVV, which would like to see a $5^{\circ}$ per cent reduction in non-Western immigration.

In a similar pattern to the Netherlands, the United Kingdom has tended to prioritise domestic public opinion in favour of political gains at the European level (DutchNews 2011b). For instance, the UK prefers to participate selectively in EU arrangements so that it can opt in and opt out when it is electorally beneficial to do so (Geddes 2005: 723). This is in part related to the fact that the British public is not very supportive of the UK's adoption of EU immigration policy. As already noted, nearly half of the population (46 per cent) felt in 2009 that $\mathrm{EU}$ policies had a negative influence on immigration levels in the UK, and only 21 per cent believed that EU policies had a positive influence on levels of immigration (26.6 per cent believed the EU had no influence, and 7 per cent either did not know or did not answer the question). Overall, in terms of confidence in delegating important decisions to the EU, only two per cent of the British population felt confident that EU decisions are made in the interests of the UK. The cases of the Netherlands and the UK point to the inherent difficulties in negotiating the concerns expressed in public opinion while participating in the European Union.

\section{Conclusion}

This chapter has shown that immigration is a hotly contested issue in many parts of Europe, where some countries are relatively new immigration destinations. Throughout contemporary Europe, public attitudes towards different types of migration are divided. Some of these attitudes stem from fears about the economy, while others stem from concerns about the impact of new migration flows on national identity. This chapter has shown how institutions within the EU have been working towards a greater harmonisation of 27 immigration policies in response to the transnational 
nature of migration. However, moves towards an increasing role of the EU in immigration policy have been met with significant resistance from populist radical right-wing parties on the one hand, and with calls from NGOs for better human rights standards on the other. But most of all, the EU must contend with broad public opinion that not only fails to demonstrate overwhelming support for EU institutional involvement but also demonstrates little support for an increase in migration flows in general. Raising the standard of cultural, social and political rights for new migrants in what is sometimes a fairly hostile social and political environment will provide multiple challenges for national governments and EU institutions in the years ahead. 


\title{
$4 \quad$ Shifting dilemmas
}

\author{
Multiculturalism and integration policies in Europe
}

\author{
James Jupp
}

\section{Introduction}

The concept of the nation-state based on a common culture developed from the French Revolution and the work of German theorists such as G. W. F. Hegel. It assumes uniformity in language and beliefs, although not necessarily in religion. In Europe and Asia, historical myths sustain the idea that the nation has evolved over many centuries, conquered many enemies and developed unique ways of doing things. These may be as trivial as drinking beer rather than wine or as complex as having a unique language.

The myths, traditions and language that allegedly give form to a nationstate come into conflict with multiculturalism as a method for integrating immigrants or other ethnic minorities, which is consequently resented. Assimilation is often preferred, both officially and by the majority of the public. Those who have immigrated from other nation-states may find this difficult to accept. Multiculturalism has more to offer them. The same is true for indigenous minorities who may have an ethnic homeland within the larger society. These two social groups may have different strategies for dealing with their alienation from the dominant culture. They may seek devolution within a homeland if they are indigenous, or they may prefer to socialise with their compatriots if they are immigrants. Both responses are widely found in Europe and sometimes encouraged by the EU. In the past, however, both social groups have often been rejected and considered divisive and their subjects criticised, isolated or, in extreme cases, driven out altogether. The most extreme form of insistence on a uniform common culture was in Nazi Germany. Much support for European multiculturalism reflects a desire to reject that history. But it is often a reflection of liberal democratic values that hold that individuals must choose their values and lifestyle for themselves. Multiculturalism, as a management technique for integrating immigrants, has had the greatest impact in the Scandinavian states. Assimilation into the nation-state has had more influence in Greece, Austria, Poland and Hungary. Within the EU, the assimilation approach has recently begun to challenge the multicultural consensus. The election of conservative governments has reduced support for multiculturalism in states like Sweden as it has in Canada and Australia earlier. 


\section{Managing cultural diversity}

Most nation-states' are culturally and religiously varied and have become increasing so due to the ease of travel and the size of migration (Hammar 1990). ${ }^{1}$ The self-determination of nations, based on the assumption of ethnic uniformity, does not take into account minorities within the nation or the economic viability of self-determination. Many states have also experienced ethnic conflict and the forced movement of people within its boundaries, giving rise to the United Nations refugee category of internally displaced persons. The poor moving to richer societies and the persecuted to safer havens have unleashed significant changes in countries receiving such people. It was mainly to manage the impact of these changes that policies broadly termed 'multicultural' were introduced in many developed democracies from the 1970 s.

Most nation-states are based on myths of common cultures, beliefs, ideals and inheritances. Interestingly, religion is not always considered an important consolidating factor. However, the reality for most nation-states has recently been a degree of cultural fragmentation following the creation of many new post-colonial states with mixed heritages and the increasing variety in the ethnic composition of populations created by mass migrations. As guardians of the national ideal and preservers of social cohesion, governments have been faced with the task of managing diversity (Dacyl \& Westin 2000; Joppke 1999).

The diversity being managed varies greatly with the laws of the managing authorities (Bauböck, Heller \& Zollberg 1996). In Germany, the United States, Australia, South Africa, Canada or New Zealand, race may have been a central factor in determining civil rights, but this was not the case in the United Kingdom or in France. No language but French has official status in France, while in South Africa, whose population size is comparable to that of France, eleven languages have official status. The only common factor in language policies in democracies is that 'indigenous' languages (Welsh, Irish, Frisian, Basque) have official standing but 'migrant' languages (Punjabi, Bengali, Tamil, Gujerati, Chinese) do not, despite often being spoken by more people (Kraus 2008). Migrants may be tested in the official language before being granted citizenship. Religious tests are not normally a basis for citizenship and are constitutionally banned in the United States, France and Australia.

1 For a much earlier secular theorising of diversity within the multicultural Austro-Hungarian empire, see Bottomore (1978). 
Apart from race and language, other factors likely to be managed in multicultural democracies in Europe and elsewhere include external loyalties, customs and practices, and legal principles. Diversity is often managed through citizenship policies, which are varied in the degree to which citizens can maintain their cultural heritage. Dual citizenship was only made available to United States and Australian citizens in the early $21^{\text {st }}$ century, having always been available to the British. Based on legislation dating from 1911, German nationality was based on German ancestry and only recently became readily available to others.

\section{Multiculturalism, integration and assimilation}

The essential feature of multiculturalism that distinguishes it from other methods for ethnic management is its recognition of the continuing influence of ethnic variety and catering for it in the delivery of services and the protection of rights, usually in consultation with those affected (Parekh 2006). This approach rejects the concept of immigrant assimilation into the majority culture within one lifetime. It sits comfortably with the notion of racial equality but not of cultural relativism, as it is essentially liberal. This goes beyond classical liberalism in maintaining minority languages, religions and cultures, provided these are deemed by the state as consistent with social cohesion and harmony. An extreme version of multiculturalism is devolution or federalism on a cultural basis, as in India. An original model was designed in the Soviet Union and Yugoslavia and collapsed with the end of the communist systems. A religious basis for such devolution is rare. One example still survives in Northern Ireland, which was designed in 1921 to protect the Protestant minority from control by Catholic Ireland.

Opponents of multiculturalism frequently use the spectre of ethnic federalism or secession as a threat to the cohesion of existing nation-states. But ethnic federalism or secession usually needs a viable geographical basis, whereas immigrants are scattered between different cities. Québec separatism in Canada and Swiss federalism depend on the principle of 'first arrivals', not recent immigration.

The democracies adopting multiculturalism since the 1970s have been overwhelmingly Christian, if only nominally. Ethnicity was normally defined in secular, and especially linguistic, terms. Even this could be politically disruptive, as in Belgium, but was often resolved by bilingualism (as in Canada, Spain, Wales, New Zealand, Finland and Switzerland). Prior to the 1970s, no Western democracy had a substantial non-Christian population 
with a geographical base. Minority issues in countries such as the United States, Britain, France and the Netherlands were defined in racial terms. This changed quickly and sometimes dramatically in the period between 1970 and 2000 (Kucera, Uçarer \& Puchala 2000).

\section{Immigration, refugees and religion}

While the largest number of migrants is found in the largest states (the US, Germany, France, Spain and Britain), the largest proportions are found in quite small states such as Austria, Denmark, the Netherlands, Switzerland and Sweden, and in the four 'settler' societies of the US, Australia, New Zealand and Canada. Most states do not keep census figures on religion, which are prohibited altogether in the US in order to maintain the separation of church and state. Australia, Canada and New Zealand all keep census data on birthplace, language and religion. The UK started to do so in 2001 to identify its large South Asian population. The only languages recorded in the UK are Welsh and Scottish Gaelic. Australia and Canada record not only about 100 overseas languages but also a wide range of Aboriginal languages, many spoken by very small and declining numbers (Jupp \& Clyne 2011). Many multicultural democracies with multicultural policies have an inadequate statistical base to judge whether such policies have any impact. Controversially, much of the census data gathered in the UK and the US are based on racial identity (e.g. Black British, Hispanic), while neither Germany nor France have census data on their large Muslim populations.

Table 4.1 Foreign born and Muslim population of 21 selected democracies

\begin{tabular}{lccc}
\hline State & Population & Foreign Born & Muslim \\
\cline { 2 - 4 } & (million) & $(\%)$ & $(\%)$ \\
\hline Austria & 8.3 & 14.9 & 4.2 \\
Australia & 22.3 & 26.9 & 2.2 \\
Belgium & 6.9 & 5.9 \\
Canada & 10.7 & 20.1 & 1.9 \\
Denmark & 33.3 & 9.5 & 3.7 \\
Finland & 5.5 & 3.8 & 0.1 \\
France & 5.3 & 10.2 & 6.3 \\
Germany & 63.1 & 12.3 & 4.0 \\
Greece & 82.1 & 8.7 & 0.9 \\
Hungary & 11.2 & 3.1 & 0.2
\end{tabular}




\begin{tabular}{lccc}
\hline State & Population & Foreign Born & Muslim \\
\cline { 2 - 4 } & (million) & $(\%)$ & $(\%)$ \\
\hline Ireland & 4.5 & 13.8 & 0.7 \\
Italy & 59.8 & 5.6 & 1.0 \\
Netherlands & 16.4 & 10.1 & 3.5 \\
New Zealand & 4.3 & 23.0 & 0.9 \\
Norway & 4.8 & 7.4 & 2.0 \\
Portugal & 10.6 & 7.2 & 0.1 \\
Spain & 45.6 & 10.8 & 2.0 \\
Sweden & 9.2 & 12.3 & 3.6 \\
Switzerland & 7.6 & 22.9 & 4.3 \\
United Kingdom & 61.4 & 10.2 & 4.7 \\
United States & 304 & 12.8 & 0.5 \\
\hline
\end{tabular}

Note: Muslim populations are mainly estimates; other totals are census-based. Definitions of overseas/foreign born birth vary. These figures should not be used for exact calculations.

Sources: 2011 Pew Forum on Religion; UN World Population Policies

\section{Multiculturalism in action}

A common criticism against multiculturalism is that it has never been defined. It would be more correct to say that it has been defined in action as a set of policies that varies from state to state. A further criticism is that it regards all cultures as equally valid and thus privileges practices that may be incompatible with liberal democracy. This is quite untrue but is particularly relevant to the accommodation of religious variety (Levey 2008). Social situations, political traditions and ethnic and linguistic variety differ between one democratic nation-state and another. Consequently, there are few uniform features of multiculturalism or of the challenges to it. Nonetheless, we can identify several features:

(a) Some states have never officially adopted multiculturalism: the United States, Germany, France, Greece, Denmark, Austria, Portugal, Finland and Ireland (Brubaker 1992). Italy, Finland, Germany and Ireland have official bilingualism for small indigenous minorities, but not for immigrants. The United States has official bilingualism in some Hispanic and Chinese areas, but English Only policies elsewhere (Higley, Nieuwenhuysen \& Neerup 2009). These states may have local government based services of a multicultural nature for immigrants, as in Copenhagen, Berlin, Los Angeles, New York, Vienna and Bologna.

(b) States that have devolution on a cultural or linguistic basis: Spain, Switzerland, and Belgium. These are responding to local political 
imperatives and do not make similar concessions to immigrants. Spain and Belgium have had serious problems of ethnic separatism based on language, which were resolved by devolution to French and Flemish in Belgium and to Catalan and Basque in Spain.

(c) States that have a degree of multiculturalism nationally and locally but not as a stated national policy: United Kingdom. British multiculturalism has political and cultural devolution for Scotland, Wales and Northern Ireland, but not for migrants.

(d) States which have a fully developed national policy for immigrants, settled groups and indigenous people on a secular basis; Canada, Australia, New Zealand, Sweden, Norway. All have critics within the political system.

(e) States that have adopted and then rejected multiculturalism: Netherlands.

Special services for immigrants are maintained in major cities such as Amsterdam and Rotterdam. All Dutch political parties now oppose further immigration

\section{Defining multiculturalism in practice}

The levels and origins of immigration are varied and change over time. Discrimination based on race may be modified or abandoned, as in Australia, New Zealand, the United States and Canada. People not previously sought may be permitted or even encouraged to enter. An important aspect has been limitations on those unable to speak the majority language, even though they had previously been attracted as factory workers (e.g. in Australia and Germany). The political situation, such as changes of government, also influences the adoption of multicultural policies. In general, the liberal or social democratic side of politics has tended to be more favourable to multiculturalism, while conservatives see themselves as defenders of the nation-state and of Christian and national values. The picture is more nuanced when we include trade unions, which traditionally belong on the left side of the political spectrum but object to immigrant labour, and the business world, which tends to be conservative but supports immigration when it can fill gaps in the labour force and create growth in the domestic market.

Each multicultural programme is developed at the level of the nationstate, although local government may have a role and the EU works towards 
uniform regulations and the protection of minority languages, however slowly (Kraus 2008). States like Germany and France deny that they implement multicultural policies, but cities within them may well provide services similar to those provided by governments pursuing multiculturalism such as in Sweden or Australia. Much public policy in the United States is implemented at the state or local level, or by judicial decisions.

Constructing a single model of multiculturalism from these varied situations is much easier for those opposed to the whole enterprise than for those in favour of it. In 2010-2011, the national leaders of Germany, France and Britain all declared their scepticism, while the Netherlands and Denmark had already cut back on a number of services for immigrants and became more vocal in their defence of the national 'way of life'. A change in government in both Australia and Canada had led to a move away from multiculturalism (Jupp 2007), but with Australia changing its government again, it reverted to the previous model. In the same short period of time, a single Norwegian massacred 77 people at a camp of social-democratic youth in a self-declared war against multiculturalism and the Muslim drive to world domination (Berwick 2011). All these events, including the London riots of 2011, were thrown into a mixture of arguments that had little to do with the modest and helpful social programmes that characterised multiculturalism in those democracies that endorsed them.

\section{Islam and the backlash}

In most societies, the arrival of migrants from different religious and cultural backgrounds is controversial. A popular argument that has gained acceptance in recent years is set out in Bowling Alone, a book by Robert Putnam (2000). In his view, modern society has spawned a greater degree of suspicion as people of different cultures live and work in close proximity to each other. This is the case in many American cities. This additional weapon in the armoury of opponents of multiculturalism is more sophisticated than the previous claims that America was becoming flooded with foreigners because it had lost control over its borders (Brimelow 1995). Even more influential for public policy was Samuel Huntington's prediction that civilisations - and not nation-states - will clash, and that a conflict was imminent between the Islamic and the Western democratic civilisations (1996). This prediction preceded the major involvement of the United States in Muslim countries such as Iraq, Somalia and Afghanistan and its eventual support for the 'Arab Spring' of 2011. 
These intellectual propositions were most influential in the US, where they originated, but were politically more relevant in Europe, to which an increasing number of Muslims had been emigrating from the $1960 \mathrm{~s}$ (McGarry \& Keating 2006). Britain, France and Germany had all encouraged immigrants from Pakistan, North Africa and Turkey respectively (many of whom were Muslims) as a source of industrial labour (Castles 1984; Castles \& Miller 1998; Kucera et al 2000). Several other states had resistance to Muslims engrained in their national cultures, most notably Greece, Spain and Serbia. Roma, many of them Muslims, started moving into Western Europe from the Balkans and central Europe as the European Union expanded and lowered its international borders (Hellyer 2009). Initially, these arrivals were resented for relying too much on state welfare, but they were not considered a threat to the indigenous culture (Banting \& Kymlicka 2006). This changed over the years as Muslims began to settle permanently, raise families, build mosques and enter local politics. Such fears were realised with the wave of terrorism from 2000, which included major bombings in Europe and Britain as well as 9/11. Huntington's clas of civilisations was already starting. It cut right through disintegrating Yugoslavia and swept into Iraq and Afghanistan.

Multiculturalism had originally been a programme for settling similar but not identical people. It was strained in Britain when migrants began to wear South Asian clothing and immigrants from Africa and the Caribbean stood out due to the colour of their skin. Australia and New Zealand had few highly visible non-European immigrants until the 1970s. Race riots and tensions began in England as early as 1958, and race has remained a political issue up to the present. In Australia, the Immigration Restriction Act prohibiting non-white people from settling was dismantled just six years before a multicultural policy was adopted in 1978 .

Canada also had very little non-European immigration originally, although it invented an official classification of 'visible minorities'. These were to receive assistance and protection. While these changes opened up the whole world's access to the richer societies, migrants remained overwhelmingly poor, uneducated and therefore at the lower levels of the labour market and society in general (Schierup, Hansen \& Castles 2006). In Britain, however, the great majority of immigrants were British subjects and their access to political life was easier than elsewhere.

Race remained at the heart of the multicultural problem until the end of the century, especially in Britain. Consequently, the possibility that religion was a different social category and the cause of social problems tended to be either overlooked or focused on anti-Semitism. Race-relations agencies were 
set up with the best of intentions, only to become involved in definitional problems such as whether Jews and Sikhs were a 'race' or whether religions should be protected from defamation and blasphemy (as they had been in past centuries and were in some Muslim states). But the greatest problems arose from the spread of Islamist terrorism and its alleged basis in Islamic values.

Armed with Huntington's thesis, many subscribed to the idea that Islam was at war with the West in general and with Christianity and democracy in particular. This view was sustained in the light of well-publicised statements by a handful of imams and ayatollahs who said precisely that. Throughout Europe, the popular media was hungry for anti-Islam stories, from the Middle East and Central Asia. One event that had the effect of turning the Netherlands away from its once liberal policies was the murder in 2004 of film producer Theo van Gogh by a Muslim of North African descent. The murder of politician Pym Fortuyn, an opponent of Muslim immigration, also played a part in the growing disillusionment with multiculturalism, even though his assassin was Dutch.

\section{Clashes with the majority culture}

That some religious practices and attitudes clash with established liberal traditions and laws is undeniable in all secular democracies, as in many others. Religions tend to be conservative, especially those claiming authority from sacred texts interpreted over long periods of time by clerics and theologians. The widespread belief among Muslims that electoral politics are haram (forbidden) is an important example. Established democracies, in contrast, have mostly undergone dramatic changes in laws relating to gender, race, electoral systems and the public role of religion since 1945. The approved multicultural method of coping with clashes between majority religions and minority practices and laws is negotiation (Banton 1985). This assumes an authoritative religious leadership with whom negotiation is possible. It becomes more difficult when there is no generally agreed leadership, or when fundamentalist groups within a religion do not accept compromise over what they regard as God's demands.

Islam, Buddhism and Sikhism all lack unchallenged centres of authority, but the problem lies not only with non-Christian religions. With one billion Christians and a similar number of Muslims in the world, multicultural variety within religions is as likely as between them. There is no real reason why the secular state should worry about the hijab any more than it now 
does in Britain about the Sikh turban or even the ritual knife, the kirpan. That the full burqa may upset people when worn in public places might be a piece of advice given by Islamic imams to their flock. Compromise works in two directions. The clue to its success is that neither the secular state nor the religious minority refuses to compromise. Muslim representatives in several democracies have asked for 'legal relativism' or the limited application of shariah law, as in some Asian states. This applies only in limited areas, but as soon as these claims become politicised, conflict escalates, despite the fact that Jewish communities have successfully negotiated similar minor concessions over many years and that Jehovah's Witnesses have contracted out of many civic obligations.

Multicultural approaches favour ecumenical collaboration and enhance the likelihood of mutual understanding and compromise (Modood 2006; Norris \& Inglehart 2012). Confrontation and prohibitions have the opposite effect. Banning the hijab, opposing the building or use of mosques and temples, or even the wearing of distinctive and religiously sanctioned clothing have all occurred in otherwise liberal democracies. Many controversial issues have been resolved in recent years, including the exemption of some minorities from military service or voting; the burial or cremation practices of Muslims, Jews and Hindus; ritual slaughtering for Muslims and Jews; interest-free banking and finance; religious holidays; marriage and divorce; school and sporting uniforms; and food choices in public institutions. The great majority of these can be, and have been, negotiated in liberal, multicultural societies. Shariah law, however, is so extensive in its implications that only selected elements have been accommodated.

At the core of many difficulties of adaptation and compromise is the role and social position of women (Hassan 2008). Most developed democracies have radically advanced their legislation for gender equality since the $1960 \mathrm{os}$. These reforms go well beyond the beliefs of newcomers and, indeed, of many religious institutions, including Christian ones. As many supporters of multiculturalism also support gender equality, this creates a strain within the ranks of reformers, which is often extended to attitudes towards homosexuality. Media excitement about issues such as female circumcision or honour killings keeps the debate heated. Both are illegal in multicultural democracies and are not confined to Muslims or even at all common.

The most serious problem in gaining acceptance for multiculturalism in recent years has been the rise of Islamic terrorism, as evidenced by the 9/11 attacks in the US and related attacks in Britain, France, Spain and the Netherlands. The three most committed multicultural societies - Canada, Sweden and Australia - have not had this experience, but have detected 
and frustrated potential plots. When multiculturalism was first developed in the 1970s, violence was associated with nationalism rather than religion, but since 2000, Islamic terrorism has been one of the central concerns in managing diversity. It has destroyed multicultural programmes in countries like the Netherlands and Denmark and justified assimilative and repressive policies throughout the democratic world.

\section{The impact on public policy}

While much attention has been focused on specifically anti-immigration and extreme 'right' parties, most public policy continues to be made by longstanding ruling parties responding to their electorates. As most European governments are coalitions or dependent on minority support, anti-immigration parties may exert considerably more direct influence than they do in the one- or two-party governments of Britain, Australia, Ireland, Sweden and New Zealand. They may even, as in the Netherlands, give power over immigration to a minister from a minority party. But a more normal reaction in all systems has been for the major conservative party to pre-empt nationalist and even xenophobic policies and thus hope to undermine the vote for opponents. In Canada, the initially influential Reform Party, which specifically opposed multiculturalism, merged into the Conservative Party in 2003. It had secured 19.4 per cent of the national vote in 1997.

Anti-immigration sentiment has also exerted influence on the major party of the left. British Labour, like many of its European counterparts, began to stress the need for national unity and social solidarity from 2001. Australian Labor endorsed many of the policies of the Liberal government in 2001 in response to the $9 / 11$ attacks. Other social democratic parties were less willing to shift, but some suffered electorally as a result. Not all conservatives succeed (see Table Two). In Austria, the Freiheitliche Partei Österreichs (FPÖ) lost half its vote in 2002, but this went over to the mainstream Österreichische Volkspartei (ÖVP). In Switzerland, the Schweizerische Volkspartei (SVP) supported a referendum, opposed by all other parties, that would have made it almost impossible for asylum seekers to enter by land. This was narrowly defeated by referendum in November 2002. The French Front National saw its vote rise and fall and then rise again with a change in leadership.

Policy shifts in the last decade in a rightward direction may be summarised as:

- Reasserting national culture, assimilation and loyalty;

- Tightening control over asylum seekers and immigrants; 
- Seeking international co-operation in controlling movement;

- Reducing commitments to multiculturalism and humanitarianism;

- Attempting to institute more 'rational' immigration systems;

- Increasing resources and powers for security organisations.

These shifts have not destroyed the work of previous decades in protecting human rights and racial equality, nor have there been blanket prohibitions on manifestations of religious variety or the expression of unpopular views, but progress towards more effective multiculturalism has stalled. The equation of Islam with terrorism has made life difficult for many Muslims, and some Muslim activists have not made the lives of their coreligionists any easier by expressing extreme conservative views consistent with their own religious beliefs but alien to the liberal humanist reforms that underlie multiculturalism. Some Christian revivalists and Pentecostalists have willingly joined in the battle.

\section{The enemy within}

Many critics of multiculturalism and of 'alien' immigration fear the possibility of an 'enemy within' either subverting the national culture or threatening law and order. The enemy within has shifted over the years from the Irish to the Mafia and now to the Islamic fundamentalists. This fear has less to do with race but more to do with culture. It is fed by American Internet attacks on 'Eurabia' by prolific writers such as Bat Ye'or (see Berwick 2011; Bat Ye'or 2005). However, the 'enemy within' - the ones subverting liberal democracies - might well be the militant opponents of multiculturalism (Gibson 2002; Mudde 2007; Ignazi 2006; Vertovec \& Wessendorf 2010). The extreme examples are, of course, the one-man assassin Anders Breivik in Norway in 2011, and his predecessor, Timothy McVeigh, in Oklahoma in 1995. Between them, they killed over 300 innocent people, more than most Islamic terrorists in liberal democracies have done apart from 9/11. Both saw themselves as supreme patriots. Breivik quotes Robert Spencer and Bat Ye'or at great length in his massive manifesto (Berwick 2011). Robert Spencer, an American Catholic, is the director of Jihad Watch, author, journalist and broadcaster.

These extreme individuals are exceptional. They are much less influential than political parties, the media and organisations that oppose multiculturalism and internationalism and defend the nation-state and its unique culture, often combining this with open or qualified racism (Bauböck et al 1996; Brubaker 1992). While Muslim and other active terrorists may be 
outlawed and hunted down, these respectable critics can often use the machinery of electoral politics and freedom of expression and publication. They may even have close relationships with long-established major parties or have infiltrated their organisations. Their overt aims of defending the nation against outsiders often have a considerable basis in public opinion. Their natural constituency is amongst conservatives and the religious, but this is not universal. Nor is their social basis only in the 'lumpen proletariat'. Most of their leaders are middle class. Their organisational heritage can often be traced to anti-Semitism or fascism, but this has been abandoned in favour of their prime target, Islam. Indeed, extremists as varied as Breivik in Norway and Geert Wilders, a right-wing politician in the Netherlands, have regarded Jews in general and Israel in particular as valuable allies against the Muslim threat (Vossen 2011). The Greek Golden Dawn is fairly unique in favouring openly fascist symbols and arguments, though these are important in some states of the former Soviet Union, including Russia.

In post-war Britain, the remnants of Mosley's pre-war British Union of Fascists formed and reformed in the League of Empire Loyalists, the National Front and the British National Party (BNP), which is currently outflanked by the English Defence League, whose main concern is with Muslims. Organised racism has had little electoral success in any of the English-speaking democracies. A galaxy of fearsome American Internet warriors, such as the Aryan Nation or Storm Front, has a wide-ranging audience. However, most of the influential criticism of multiculturalism and Islamism comes from willing journalists and broadcasters in the mass media and conservative politicians. For example, Wilders, the Dutch leader of the PVV party, has been officially invited to conferences of the British Conservatives and the Australian Liberals in recent years.

In much of Europe, the rise of right-wing, anti-immigration and antiMuslim parties can be spectacular, aided by proportional representation systems that allowed them to gain parliamentary seats even with small electoral followings. Openly racist, fascist or Nazi parties are outlawed in Germany, and the vote for extreme nationalist parties is very small. Elsewhere, such parties have been doing very well, with the exception of the French Front National of Jean Marie Le Pen, which was temporarily affected by splits (Berezin 2006), and the Dutch PVV, which lost one-third of its support in the 2012 elections. This has not affected the open hostility to Muslims shown in some recent French legislation, but France and Germany were never officially multicultural (Brubaker 1992).

Anti-immigration and anti-Muslim parties have scored well and are increasingly present in the smaller EU states. Their voters feel that their 
distinctive culture is under threat, even when, as in Finland, there is almost no Muslim population. Hostility to the EU characterises almost all of the far-right parties, including those in Britain like the BNP and the UK Independence Party (UKIP). Ironically, the proportional representation electoral system allows small parties like UKIP or the BNP to be elected to the European parliament, even when they cannot get elected to their own national parliament. Such parties have informally allied with the French FN and Hungarian Jobbik to form an EU parliamentary party, the European Alliance of National Movements (EANM).

Table 4.2 Support for anti-immigration parties in Europe and Australasia

\begin{tabular}{|c|c|c|c|c|}
\hline State & Party & $\begin{array}{c}\text { Recent Vote } \\
\text { (\%) }\end{array}$ & $\begin{array}{l}\text { Election } \\
\text { Year }\end{array}$ & $\begin{array}{r}\text { Government/ } \\
\text { Opposition }\end{array}$ \\
\hline \multirow[t]{2}{*}{ Austria } & FPÖ & 18.0 & 2011 & Government \\
\hline & Alliance (BZÖ) & 10.7 & 2011 & Government \\
\hline Belgium & VB & 7.8 & 2010 & Opposition \\
\hline Denmark & Danish PP (DF) & 12.3 & 2011 & Opposition \\
\hline Finland & PS-True Finns & 19.1 & 2011 & Opposition \\
\hline France & Front National & 13.6 & 2012 & Opposition \\
\hline Germany & NPD/REP/DVU & 1.8 & 2009 & Not applicable \\
\hline Greece & Golden Dawn & 7.0 & 2012 & Opposition \\
\hline Hungary & Jobbik & 16.7 & 2010 & Opposition \\
\hline Ireland & Imm. Control P. & n.a. & 2011 & Not applicable \\
\hline \multirow[t]{2}{*}{ Italy } & Lega Nord & 8.3 & 2008 & Government \\
\hline & La Destra & 2.4 & 2008 & Not applicable \\
\hline Netherlands & PVV & 10.1 & 2012 & Opposition \\
\hline Norway & Progress Party & 22.9 & 2009 & Opposition \\
\hline Poland & Polish National Party & 0.29 & 2005 & Not applicable \\
\hline Portugal & Popular Party & 11.7 & 2011 & Government \\
\hline Spain & MSR/Esp.2000 & 0.03 & 2011 & Not applicable \\
\hline Sweden & Swedish Democrats & 5.7 & 2010 & Opposition \\
\hline Switzerland & Swiss PP (SVP) & 25.9 & 2011 & Government \\
\hline \multirow[t]{2}{*}{ United Kingdom } & BNP & 1.9 & 2010 & Not applicable \\
\hline & UKIP & 3.1 & 2010 & Not applicable \\
\hline Australia & One Nation & 0.2 & 2010 & Not Applicable \\
\hline New Zealand & NZ First & 6.6 & 2011 & Opposition \\
\hline
\end{tabular}

Note: 'Government' means either that the party is in government or that the government depends on the party in parliament. 'Opposition' means that the party is represented in parliament but that it does not support the government. 'Not applicable' means that the party is not represented in parliament. 'Recent vote' is for the latest lower house election.

Source: European Election Data Base 
Multicultural policies have been hit by the decline of social democracy, the reassertion of the nation-state and its official culture, the EU economic crisis and the willingness of secular authorities to defend Christian values against Islam. This is a formidable challenge. The result, so far, has been a decline in support for multiculturalism and its abandonment by many liberal democracies. Yet the 'enemy within' - the Muslims - are still there and still need to be brought within the political fold as their locally born and citizen numbers increase. Most liberal democracies are multilingual, multi-religious and multinational, in varying degrees and from different sources. Simply discriminating against one group alienates members of that group and identifies it as a problem. Most European and English-speaking democracies, other than the United States, are not predominantly 'religious' and aim to equalise the rights and duties of all their citizens, even those who are not Christians. But such an aim becomes less likely to be reached as support for multiculturalism recedes and draconian security, immigration and refugee policies are adopted.

\section{The challenges to multiculturalism in liberal democracies}

Several common features emerge from this apparent confusion. One is the continuing adoption of multicultural and multilingual services and organisations in cities of immigrant concentration. This is pragmatic and not directly aimed at social cohesion, integration, or nation-building. Such services are most common with social democratic/reformist city councils, but not confined to them. Another common feature is that language diversity is not institutionalised for immigrants, but only for long resident minorities (Kraus 2008). Emphasis is put on learning the majority language, usually as a precondition for citizenship. Otherwise, language policies are mainly directed towards conveying official and useful information. In practice, most European education systems aim at proficiency in up to four languages, which is not the case for English-speaking societies. These are not usually the languages of recent immigrants. Another common feature, as outlined already, is that discriminatory policies are advocated against Muslims but only accidentally affect other religions.

Significantly for the above discussion, Muslims are not normally seen as the core of a particular problem in those societies where they form one per cent or less - namely Finland, Greece, Italy, New Zealand and Portugal. The newly emergent Greek Golden Dawn is hostile to all non-Greeks, specifically mentioning Albanians, but not for religious reasons. Where the percent- 
age of Muslims rises from as low as 2.2 per cent (Australia) up towards six per cent (France), there is hostility, fear and anxiety. Immigration, multiculturalism and Islam become major overlapping issues advanced by minority parties, by elements within the conservative majority, and by social democratic parties responding to working class voters. The obsession of many democracies with the threat from their Muslim minorities has become a significant distraction from a variety of social problems. It leads to the redirection of growing resources and powers that could be used more fruitfully.

Islam presents a threat that liberal policymakers in democratic nationstates believe they have to cope with (Klausen 2005; Poynting \& Mason 2008; Michaelsen 2012). Arguably, Islam is the only or most important issue not only in the smaller EU states but in the EU as a whole. However, even EU critics of conservative origin such as the UKIP mention Islamic fundamentalism as one of their targets. Traditional racism based on physical appearance has become discredited, except for such marginal street gangs as the English Defence League or German neo-Nazis. Anti-Semitism has withered. Defending the European Christian heritage against Islam has taken its place. The 'war against terror' has become the 'war against Islam' in many eyes, including those of Muslims.

Multiculturalism in Western democracies now faces three intertwined dilemmas: a reassertion of loyalties to the nation-state; a fear of being overrun by outsiders; and a specific objection to Muslims. These may have an underlying element of economic fear and resentment, but their impact is often greatest in the richer nations of Europe, as suggested by the vote for hostile parties in Switzerland, Norway and Austria. All but six member states of the European Union have smaller populations than Australia. They also have distinct languages and historical traditions. The fear of being swamped by another culture has considerable force. As long as there are wars, dictatorships or social breakdown in Africa, Asia and Latin America, there will be refugees in numbers large enough to sustain these fears and undermine support for multiculturalism. The political opponents of multiculturalism will be identified with national, regional and international policies designed to limit immigration. They will also discourage the maintenance of minority beliefs and practices by those already within the state borders through previous migrations or - increasingly, by birth. The nation-state then becomes an agency for imposing values, frequently of religious origin - on its own citizens, many of whom may not share them.

There is already escalating resentment and hostility towards these trends among some ethnic minorities, often compounded by high levels of youth 
unemployment. The London riots, the Occupy movement on Wall Street and the Greek demonstrations against the budget cuts demanded by the EU leaders suggest that spontaneous youth rebellions may be the next challenge to social cohesion. These are likely to be 'multicultural', but not in the benign sense used until recently. Post-rioting research by the London School of Economics suggests that half the London rioters were students, half were Black British and the majority were unemployed. Resentment against the police was widespread, as was the case 30 years before during the Brixton riots of 1981. In the most recent riots, religion is irrelevant, but youth and ethnic disadvantage are not. Where religion is relevant is in the regular rioting over 'insults to the Prophet', from the fatwah on Salman Rushdie to the international events of 2012. Even then, the common factor is the clash between youths and the police, with community leaders expressing their disapproval.

Equally threatening are armed gangs in the drug trade, where similar influences are at work. Criminal gangs often have an ethnic dimension, but multiculturalism has little to offer by way of solutions. Yet organised crime may be a greater threat to social cohesion than the often individual acts of jihadist terrorists. Major resentments no longer focus on the fear of labour competition, as in the past, but often on the threat to welfare states from the arrival of poor immigrants demanding government support. The common factor remains the idea that a nation-state must rest on a grouping bound together by common interests and a common culture. Erosion of this principle is believed to undermine the whole of society. Thus even well-educated and highly skilled immigrants may present a threat to national unity. This is particularly challenging when economic policies do not deliver obvious benefits, as currently is the case in much of Europe. Multicultural policies have rested on societies that usually provide prosperity and security. This is no longer self-evident. 



\section{$5 \quad$ Malaysia}

Labour migration, irregular movements and regional policies

Amarjit Kaur

\section{Introduction}

Malaysia is an important destination for economic migrants and has been open to migrant labour and foreign investment since the late nineteenth century. Whereas Chinese and Indian workers dominated the earlier colonial migration flows, currently Southeast Asian and other Asian migrants represent about 25 per cent of Malaysia's workforce. Unlike other traditional migration countries, the temporary migration route dominates migration to the country. The combination of greater regional integration and rapid socioeconomic development in the region has also transformed the causes and contexts of labour mobility, which have shaped present policies on temporary migration. Four fundamentals have framed the phenomenon of migration in Malaysia in terms of the spatial component of migration systems. First, colonial labour migration linked European colonial territories in Asia with Europe and was an important feature of the proletarian mass migration movements to Malaysia. Contemporary migration in the Asian region takes the form of both intra-regional proletarian migration and gendered migration. Second, the composition of labour migrants has also changed from essentially low-skilled migrants to include a greater diversity of migrants made up of professionals, highly skilled migrants and less-skilled workers. Third, policy intervention by countries such as Malaysia has resulted in the adoption of specific circular migration policies and the growth of a particular type of migration mobility that is regulated by both labour-sending and labour-receiving countries. Fourth, forced displacements in the postcolonial period and growing economic disparities have also led to increasing irregular migration and forced migration. There are regional arrangements regarding human trafficking and related transnational crimes in Asia-Pacific, and Malaysia has generally cooperated in combating human trafficking through regional initiatives such as the Bangkok Declaration on Irregular Migration and the ASEAN Joint Declaration against Trafficking in Persons. Nevertheless, most Southeast Asian 
governments, including Malaysia, have not ratified the 1951 UN Convention on the Status of Refugees.

The Malaysian government's relatively open approach to labour migration and the shortcomings in terms of its labour migration policy have also increased public cynicism about the state's ability to control irregular migration. This is largely because Malaysia has not successfully integrated its foreign labour policy into the broader socioeconomic frameworks and because business has become dependent on migrant workers to maximise profits. Shifting political agendas have also led to periodic crackdowns on undocumented workers by the state, followed by amnesties and the legalisation of irregular migrants, but a durable adjustment will take time because of the failure to implement long-overdue policy reforms. Crucially, irregular migration will remain a phenomenon in Malaysia, owing to policy gaps and the persistence of guest-worker programmes for hiring low-skilled migrant workers in specific economic sectors.

This chapter first presents an overview of the relationship between broader geopolitical change and international labour migration (ILM) in Southeast Asia during the colonial period. It then examines transnational mobility in the region since the 198 os against the backdrop of geographical alliances and porous borders, shared colonial legacies and the development of migration pathways associated with greater regional integration. Regional migration trends and patterns are also explored from the perspective of migration as an interdependent dynamic system (Kritz \& Zlotnik 1992), with its own web of interconnecting sub-systems for migrant sending and receiving countries. The chapter addresses Malaysia's changing immigration policies, the temporary guest-worker programme and the contexts and issues of irregular migration. Finally, Malaysia's guest-worker policy is evaluated from the perspective of the non-integration of human rights into domestic legal and political orders and the lack of any formal government commitment to protect refugees and combat forced migration.

\section{Empire, commodities of empire and Asian labour migration}

European political and economic expansion in Southeast Asia in the second half of the nineteenth century and the early twentieth century coincided with the region's greater integration into the new globalised system of production, trade and investment. The Europeans divided Southeast Asian states among themselves and became land powers, linking their colonies to their imperial economies. The new organisational structures in South- 
east Asia comprised six major realms: British Burma, British Malaya, the Netherlands East Indies (Indonesia), French Indochina, the Philippines, and Siam (Thailand). The Philippines, previously under Spain, were annexed by the United States Although Siam remained nominally independent, it had a British financial advisor and a quasi-subordinate relationship with Britain. Colonial exploitation of mineral and agricultural commodities also transformed the existing geography of production, shaping colonial labour policies and facilitating migration across national and international boundaries. The colonial powers concentrated on the production of raw materials and foodstuffs in a way that advanced specialisation, encouraged the commodification of labour and promoted labour mobility. The political developments also foreshadowed the creation of new migration pathways from India and China in the form of indentured contract labour arrangements. This new type of labour engagement is usually considered to mark the start of the modern system of (wage) contract labour in Southeast Asia (Kaur 2004a).

Asian labour mobility during this period was a defining feature of Asian globalisation and mirrored European transatlantic migration. The Asian migrants comprised mainly Chinese and Indian men who moved in response to labour-market signals, the introduction of indentured or contract labour systems that both financed and sponsored their migration and the liberal colonial policy environment in Southeast Asia. The migrants' temporary movement was thus consistent with expanding capitalist markets and the emergence of new production units of plantations, mining enterprises and markets. The movement was, moreover, sustained by the new technologies of transport. The number of migrant workers moving into Southeast Asia was large compared to European migration movements across the Atlantic to the United States. Huff and Caggiano (2007) have estimated that, between 1911 and 1929, gross migration into Burma, British Malaya (the Malay Peninsula and Singapore) and Thailand was over twice as high as gross migration into the United States. Moreover, although a high proportion of migrants returned to their countries, net inward migration amounted to around 1.55 million over these years.

There were two types of labour movements: regulated and voluntary migration. The Chinese travelled as voluntary migrants, whilst Indians, who moved mainly within British territories, went under regulated migration schemes. Chinese migration until the late nineteenth century was based on two main networks: the kinship-based migration network, and the credit-ticket system network. The kinship-based migration network involved recruiter-couriers who recruited migrants in their own villages/ 
regions, and relatives or friends in the migrants' hometown often guaranteed the passage money and travel expenses. The credit-ticket (steerage) system, which the bulk of the migrants relied upon, involved the passage money and travel expenses being met by labour brokers, captains of junks or labour agencies. The migrants were hired as indentured workers on three-year contracts; they were either single men or had to leave their wives and children behind in China. Hardly any women migrated of their own accord or as associational migrants. Apart from Malaya, Chinese migrants also went to Thailand and the Philippines to work in agricultural or mining enterprises and to engage in commerce.

Indian migrants moved mainly between two colonial establishments, namely India and Malaya, under the general jurisdiction of the Colonial Office in London. Indian migration was principally organised using open, regulated recruitment arrangements. Two migration methods were used, namely the indenture system and the kangani system. The indenture method allowed employers to utilise enforceable, usually written, labour contracts. The workers were contracted, or rather bonded, to individual employers for between one and three years, and planters used these contracts to handle their labour costs and supply. Breaches of written contracts were regarded as criminal rather than civil offences. Since most workers were impoverished, they were re-indentured for further periods. Some planters relied on an intermediary or kangani, to recruit Indian labour. The kangani method was a personal recruitment system and it became more popular when indentured labour was abolished in 1910. The Indian government (India Office) was also involved in some operational aspects, intervening in specific cases, such as ensuring a specified gender ratio. The location and work processes on plantations also necessitated and promoted women's economic participation in the sector. Women's migration was considered essential for family formation and the reproduction of labour. Importantly, the plantation structure incorporated a number of tasks that could be remunerated at lower rates, utilising "cheaper" women and child workers.

Liberal labour policies and non-restrictive immigration policies effectively led to the Chinese and Indians making the transition from sojourning to settlement by the 1930s. In the 1930s, however, the Malayan Administration introduced restrictions on Chinese male immigration by implementing a quota system on new arrivals. This move coincided with depressed economic conditions globally and falling demand for rubber and tin. Unlike Indian plantation workers who could be, and were, repatriated to India, the British had no legal means at their disposal to repatriate the 'alien' Chinese migrants to China. Nevertheless, these restrictions never 
attained the importance they did until after Malaya achieved independence. Malaya had become an immigrant nation by the 1940s. According to Furnivall (1948: 304-5), 'plural societies' had emerged in Southeast Asia. The various ethnic groups mixed but did not combine. Economic plurality had resulted in differentiated economic roles and created residential segregation and different experiences. It was clearly evident that a national consciousness based on ethnic consciousness had taken shape in Southeast Asia. Subsequently, after Southeast Asia fell to the Japanese in 1941-2, there were further transformations in the region. Japanese rule exacerbated ethnic sensitivities but at the same time emphasised unitary national identities.

When the colonial powers returned, they found a completely changed environment in the region. The growth of nationalism and independence movements foreshadowed decolonisation and the emergence of independent nation-states. These independent states, which inherited their boundaries from imperial structures, were constructed around an ethnic majority group, leaving many smaller ethnic groups as enclave communities and presaging sectarian violence (Cribb \& Narangoa 2004). Asian labour migration also came to an end with the dismantling of empires. The emergence of ethnic Malay nationalism, which intensified during the Japanese occupation (Booth 2008), was soon followed by the implementation of strict border controls, and racial/ethnic logics became more pronounced in the region. Citizens were categorised on the basis of their nationality and 'marketable' skills, and the new national governments in Malaya, Burma and Thailand effectively closed access to their labour markets (Kaur 2004b).

The above discussion presents a short background to the expansion of regional labour migration and irregular migration in the past three decades. Malaysia has become a magnet for large numbers of migrant workers from poorer neighbouring countries, particularly Indonesia. Malaysia's comparative prosperity and stability, middle-income status, and the expansion of agricultural, manufacturing and service sectors have provided new job opportunities in the region. The residential and work circumstances of migrant workers today mirror the former system of migrants' segregation and exclusion from the general population. While the Indians and Chinese under colonial rule were allowed to form associations, the present groups of migrant workers are denied most human rights and their mobility restricted. Border enforcement and the increase of state surveillance systems using the latest technology, including biometrics, are also emphasised in the government's evolving legislative structures to monitor the movement of legitimate migrant workers and irregular migrants (including refugees and trafficked persons). 
Different migrant categories (professional and highly-skilled, and temporary/low-skilled) may experience inequality in different ways (see, for example, Black, Natali \& Skinner 2005). This chapter focuses on temporary low-skilled migrant workers and irregular migrants and refugees. The latter have less clout in the migration process since they are normally constrained by factors such as the costs of migration, geographical and cultural proximity, and a greater reliance on social capital and networks.

\section{Regional labour markets in post-independent Southeast Asia}

In the period after the Second World War, the major economies of Southeast Asia experienced an important transformation from agricultural to industrial production that corresponded with the globalisation of production and shifting trade and investment patterns. Of the then ten Southeast Asian states, five states - Singapore, Thailand, Malaysia, the Philippines and Indonesia - maintained open economies under various regimes. These states also promoted industrial policies and benefitted from the relocation of labour-intensive manufacturing operations from industrialised countries to the region. Singapore and Malaysia, two of the richer states in the region, subsequently faced labour shortages after the 1970s and 1980s, and the widening wage gap in the region facilitated labour migration from Thailand (mainly to Singapore), and from Indonesia and the Philippines to Malaysia and Singapore. Malaysian nationals of Chinese and Indian origin also went to Singapore, particularly after Malaysia introduced affirmative action policies for Malays. Consequently, labour migration became a structural feature of Southeast Asian economies, persisting beyond cyclical fluctuations in the supply of labour (Athukorala \& Manning 1999). Similar to Australia and the European states, Southeast Asian states depend on temporary migration routes to meet labour shortages and have benefited from the recruitment of low-cost workers from neighbouring countries. Their immigration policies often provide incentives for skilled workers, boost circular migration flows among low-skilled workers and depend on stringent border-control regimes to exclude unauthorised migrants. The guest-worker programmes are reliant on networks, intermediaries and brokerage firms and, as discussed below, are regarded as exploitative, but migrants from the poorer countries have few options open to them.

There is a distinctively informal, or unofficial, system of transnational mobility in Southeast Asia. In this system, we can identify two groups of states based on their specific migrant characteristics: the first group, 
which includes the Philippines, Cambodia, Burma, Laos, Vietnam and Indonesia, are mainly emigration countries while the second group - Singapore, Brunei, Malaysia and Thailand - are mainly immigration countries. Furthermore, there are two primary migration corridors - specifically the archipelagic Association of Southeast Asian Nations (ASEAN) corridor and the Mekong sub-regional corridor. Malaysia, Singapore and Brunei are the major destination countries in the first corridor, recruiting workers predominantly from Indonesia, the Philippines and Thailand. Thailand is the main destination for migrants in the second corridor, who originate from countries with which it shares land borders, mainly Burma, Cambodia and Laos. Nevertheless, all the ASEAN states support the link between policy reform and economic growth and look for opportunities through economic alliances.

From the perspective of neo-liberal globalisation and the shifting national and supranational boundaries of capital, the richer states depend on poorer states in the region to augment their labour supply and keep wages down. Accordingly, the fragmentation of production, work specialisation, and new production structures and occupational categories depend heavily on migrant labour. This is principally because uneven economic growth in the region has provided conditions for the appropriation of segments of the working class from poorer states by wealthier states. Moreover, since the mainly working-class migrants have temporary status, destination states deny them citizenship rights to differentiate between foreign and local (national) workers. Crucially, migration became an important labour diversification strategy for the Philippines and Indonesia, and afterward also for Cambodia, Burma, Laos and Vietnam. The latter countries also depend on migrant workers' remittances to improve household economic resources, fund development projects and carry out poverty alleviation programmes.

The considerable increase in ILM should also be understood in the broader context of the demographic and economic circumstances in both sending and destination states, and the complementarities between them. This is crucial, since 'South-to-South' migration in Southeast Asia is more important than 'South-to-North' migration. In 2000, for example, the population of the early industrialising states, whose incorporation into the global economy corresponded with branch-plant industrial production in export-processing zones, was as follows: Singapore, 4 million; Malaysia, 22.9 million; Thailand, 61.4 million; Indonesia, 209.2 million and the Philippines 51.5 million. The first three countries' labour markets experienced a greater degree of transformation and segmentation, and these states were 
confronted with the challenges of promoting skills development and providing decent work opportunities for their citizens. To remain competitive, all three countries espoused a developmental role and instigated policies for the recruitment of cheap foreign workers from within the region in order to fill their labour force needs.

Table 5.1 presents a review of the current economic indicators in Southeast Asia affecting migration to Singapore, Malaysia and Thailand, with Indonesia and the Philippines as migrant-sending states.

Table 5.1 Singapore, Malaysia, Thailand, Indonesia and the Philippines: main economic indicators 2010

\begin{tabular}{|c|c|c|c|c|c|}
\hline Key Indicator & Singapore & Malaysia & Thailand & Indonesia & Philippines \\
\hline Population (millions) & 5.1 & 28.8 & 65.5 & 237.6 & 92.3 \\
\hline $\begin{array}{l}\text { Percentage } \\
\text { unemployed ( } 2010 \\
\text { estimate) }\end{array}$ & 2.2 & 3.4 & 1 & 7.1 & 7.3 \\
\hline $\begin{array}{l}\text { GDP per capita ( } 2010 \\
\text { estimate in USD) }\end{array}$ & 62,100 & 14,700 & 8,700 & 4,200 & 3,500 \\
\hline $\begin{array}{l}\text { Human Poverty } \\
\text { Index rank (2007/8) }\end{array}$ & 7 & 16 & 24 & 47 & 37 \\
\hline $\begin{array}{l}\text { Foreign direct } \\
\text { investment per } \\
\text { capita (USD) }\end{array}$ & 339.26 & 12.06 & 58.00 & $(-15.69)$ & 14.58 \\
\hline $\begin{array}{l}\text { Percentage of } \\
\text { population below } \\
\text { poverty line }\end{array}$ & $\ldots$ & 7.5 & 9.8 & 18.2 & 34 \\
\hline
\end{tabular}

Source: Derived from Central Intelligence Agency (2011); UNDP (2009); IOM (2010b); One World Nations Online (2011)

By 2010, Indonesia had become the fourth most populous country in the world, while the Philippines is the twelfth most populous. Apart from demographic and income disparities, the direction of major ILM flows in Southeast Asia in recent decades has largely corresponded with earlier colonial links, geographical proximity and the growth of regionalism.

\section{Malaysia's immigration quandary: Guest workers and irregular migrants}

Malaysia's guest-worker policy after the 1950s and the government's attitude towards irregular migrants and refugees are best observed by examining the 
country's labour policies and evolving immigration structures during two fairly distinct periods: 1957-1994 and 1995-2012. These periods correspond with clear economic transformations and changes in policies governing foreign labour recruitment. In both periods, the government instigated strategies to regulate ILM and manage the movement of irregular migrants. The state also used the regularisation of irregular migrants as a policy tool for labour force growth. The discussion is confined to Peninsular Malaysia, since immigration is a state matter, and economic and political factors underlying the influx of migrants in Sabah and Sarawak are different from those of Peninsular Malaysia.

\section{7-1994: Malaysia's initial foreign labour policy}

During this initial period, the independent national government instigated its first immigration-related legislation, the Immigration Act of 1959, which was intended to regulate the movement of non-citizens in the country and restricted the immigration of low-skilled workers. Next, following the creation of Malaysia, the state passed the Employment Restriction Act of 1968 which made admission to the labour market for 'non-citizens' conditional on the possession of work permits. Crucially, this meant that a large number of Chinese and Indians, many of whom had been in the country for decades, had no right of employment, despite their earlier connections and residence in the country (Kaur 2009). Thousands of Chinese and Indian Malaysians were also denied citizenship and were either expelled or repatriated later on.

After the May 1969 race riots in Malaysia and a leadership change, the government espoused state-led economic growth and launched its New Economic Policy (NEP) promoting economic growth and competitiveness. The state embarked on an export-oriented industrialisation strategy modeled on the one that Japan had pursued in its rise as an economic powerhouse and based on the new international division of labour. Simultaneously, poverty and income redistribution programmes based on affirmative action policies favouring ethnic Malays were also inaugurated. State strategy further involved the implementation of large-scale infrastructure development projects, public sector expansion and agricultural growth. Agricultural development centred on the resettlement of Malays who owned either small blocks of land or were landless. The government approved the development of large blocks of land with the support of public agencies, the most important of which was the Federal Land Development Authority (FELDA).

In the 1980s, as employment in the manufacturing sector expanded, the gap between real wages in this sector and those in the agricultural sector 
widened from one to two in 1967 to one in three in 1981 (Migration News April 1994). According to a World Bank Report (1995: 58), 14 million new jobs were created during the 1987-93 period, while the annual labour market growth rate was 3.9 per cent. The annual domestic labour force growth rate during this period was 3.1 per cent. Job creation in the public sector as a result of the expansion of government projects also drew large numbers of rural Malays to the towns and cities. At the same time, the expulsion of Indians and Chinese led to severe labour shortages in the plantation sector (oil palm and rubber) and also in the construction and services sectors. FELDA afterward became a major employer of migrant labour and hired foreign workers to cut down trees in the forests and prepare the land for commercial crop cultivation by Malay settlers. Western plantation companies also experienced similar labour shortages on their plantations. In this initial period, the government espoused a market-based approach to labour recruitment, and employers and government agencies turned to Indonesia and Thailand to recruit workers for their enterprises. They employed the services of private labour brokers or contractors, using their social networks and illegal labour syndicates to recruit workers both locally and from overseas for plantation, construction and domestic work (Kassim 1987: 267-8).

The state thus turned a blind eye to, and had few qualms about, the employment of irregular Indonesian migrants. Indonesian workers were recruited chiefly because they were from the same racial stock (bangsa serumpun) as the Malays and could easily integrate into the Malay community (see Chapter 6 in this volume). There was a sizeable Indonesian community in the country residing in squatter settlements in Selangor and, in the context of an ethnic-based, political power-sharing arrangement in Malaysia, Indonesians could contribute to the numerical strength and electoral power base of the Malays (Liow 2003; Kaur 2005). Significantly, the lack of a legal immigration policy and channels for the admission of low-skilled workers resulted in the clandestine entry of large numbers of irregular Indonesian migrants to fill labour market gaps. According to Jones (2000: 15), who cites Indonesian Ministry of Manpower records, estimates of irregular Indonesian migrant workers in Malaysia ranged from 200,000 to 700,000 in the early 1980 s. However, similar to the Malaysian workers, Indonesians preferred less arduous jobs and moved to the towns where they took up petty trading and other jobs, in competition with Malaysians.

The growing problem of irregular migration hence necessitated the development of an organised contract labour scheme based on a work-permit 
system to provide workers for specific labour-intensive sectors. In 1982, Malaysia established a Committee for the Recruitment of Foreign Workers to allocate work permits for guest workers. The government subsequently signed labour accords with labour-sending countries to establish limited channels for admitting workers within numerical limits. Previously, the state had passed a Private Employment Agencies Act to assist Malaysians seeking employment abroad. This act was used to recruit low-skilled foreign workers for Malaysian companies and state organisations, and private labour brokers and agencies were employed to recruit the workers (Kanapathy 2008). After the employers took on the workers, the labour broker's task was completed, and the workers became employees of the enterprise.

This initial government intervention in the labour market included the signing of labour accords with labour-sending countries to systematise recruitment procedures and channels. In 1984, Malaysia and Indonesia signed the Medan Agreement for the supply of Indonesian workers for the agri-plantation and domestic work sectors. The following year, Malaysia reached a labour accord with the Philippines for the recruitment of domestic workers. Labour accords were subsequently signed with Bangladesh and Thailand for the recruitment of workers for the plantation and construction sectors. The labour accords essentially approved the admission of foreign workers in low-wage jobs and were intended to be used to document and formalise their stay in Malaysia. The employment of foreign labour was overseen by the Employment (Restriction) Act of 1968 and the Immigration Act of 1957. Rema Devi (1996: 5-6) asserts that the labour accords were a 'contract labour agreement for the supply of cheap Indonesian labour on two year contracts, to meet an ostensible labour shortage in the plantation and construction sectors' and the domestic work sector.

Briefly, Malaysia's guest-worker recruitment system admitted foreign contract workers on the basis of 'individual' or 'group work' permits. This policy, which involved off-shore recruitment procedures, established the following conditions: assisted passage for workers; repayment of travel and recruitment advances by workers through salary deductions; employment with a specific employer; fixed-term employment; and the obligatory return to the country of origin upon completion of the contract (Kaur 2006: 23-51). These low-skilled foreign workers were recruited for the manufacturing, construction, plantation, services and domestic worker sectors. A key stipulation was that the workers' remuneration had to be below RM 2,500 a month ( the minimum earnings for a skilled worker) and they were hired on a Visit Pass for Temporary Employment. Migrants were employed on 
one-year work permits that were renewable for a period of up to five years (subsequently the employment periods were extended). There were age restrictions associated with these permits, and workers were prohibited from taking their dependents with them. Employers were required to obtain the work permits and were also responsible for renewing their workers' permits. However, some employers shifted the transaction costs to the foreign workers, resulting in a continuation of irregular migration flows from Indonesia and other countries. This initial guest-worker policy underscored a migration administration paradox: highly restrictive rules diluted or accompanied by the continuity of de facto reliance on undocumented economic migrants and acceptance of migrants' unofficial residence.

Against the backdrop of worsening economic conditions in Malaysia in the mid-1980s, the Malaysian Trades Union Congress (MTUC) expressed its concerns about the increasing numbers of foreign workers and rising unemployment among local Malaysians. Employers nevertheless continued to hire the 'cheaper' migrant workers and were neither required to provide accommodation nor to contribute to their employees' superannuation fund. The opposition Democratic Action Party (DAP) leaders were opposed to irregular migration from Indonesia and, in 1985, proposed a system to reward informants for information on undocumented Indonesian immigrants in the country. Demands by community groups subsequently resulted in the state deploying a special unit, Task Force VII (originally set up in the 1970 s to prevent illegal landings by Vietnamese boatpeople) to patrol Malaysian waters and stop unauthorised Indonesian boat landings. In 1986, overseas foreign labour recruitment was suspended but only briefly. Although the deployment of the Task Force was seen as a move in the right direction, there was scepticism in the country about the government's commitment to the measures, and there was division in government circles and among the public over this policy proposal.

These policy changes augmented the state's legalisation agenda for the mostly undocumented Indonesian migrant workers (see below). As noted previously, the state had surreptitiously tolerated the admission of undocumented Indonesian immigrants for temporary entry mainly for political gain. Under the 'formal' legalisation programme, the state took specific actions, the first of which was the regularisation of undocumented Indonesian migrant workers to avert any disruption to the labour supply. According to Kassim (1995: 15), Indonesians accounted for 83 per cent of the 442,276 workers who presented themselves for registration during this period. Additionally, new labour hires were suspended until the legalisation procedure was completed. The state also gained financially from this 
programme, as it was able to recoup "unpaid" work-permit fees owed by workers. Some groups in Malaysia saw the economic benefits of legalising the irregular workers and considered the policy as cost-effective; others opposed it and demanded that the government use measures introduced in the 1970 and 1980 s to stop Indochinese refugees arriving on the east coast of Malaysia. In response to increasing antagonism towards undocumented migrants, the government diverted the services of Task Force VII to assist with managing irregular immigrants (Nayagam 1991: 16).

Renewed debate on the question of the possible unhindered movement of low-skilled migrant workers also led to policy changes in foreign worker recruitment and greater interdepartmental coordination. Thus, in 1991, the government's Cabinet Committee on Foreign Workers instigated a Comprehensive Policy on the Recruitment of Foreign Workers to regulate foreign labour recruitment processes, consistent with its economic goals. This policy elucidated the following issues in the legal migration of low-skill foreign workers: recruitment procedures, stipulations and conditions of employment, and the repatriation of foreign workers. Employers requiring foreign migrant workers had to advertise vacancies in local newspapers and liaise with local employment agencies to recruit workers. If local workers were unavailable, employers could then apply for approval from the Ministry of Human Resources to hire foreigners for the positions. Labour brokers continued to be used, but Malaysian labour brokers' counterparts in the labour-sending countries had to provide detailed information about potential workers selected for work in Malaysia. Next, in October 1991, the state made it mandatory for employers to pay a levy for each migrant worker hired by them. The levy differed from one sector and skill category to another and was intended to discourage dependence on foreign workers (Kaur 2010: 385-397). From 1994, employers were also required to provide 'satisfactory' housing for workers to stop the surge in squatter settlements in the country.

The initial suspension of labour recruitment corresponded with improved border enforcement operations and the adoption of surveillance operations involving the redeployment of Police Field Force personnel along the main coastal areas of the Malay Peninsula (Kaur 2006). The 1991 surveillance programmes, called Ops Nyah I (Operation Expunge) and Ops Nyah II, were directed at halting irregular migration and conducting regularisation programmes to legalise the admission and employment of undocumented workers through an amnesty and registration programme. This became standard government strategy. Malaysia also recognised that a unilateral approach was not conducive to improved relations with labour-sending 
states and therefore restored its earlier policy of bilateral labour accords to ensure additional transparency in recruitment processes and to include labour protection measures. The policy shift enabled the government to extend its foreign labour catchment area in the wider Asian region (Kaur 2005).

\section{5-2012: A policy of managed migration}

Malaysia's development strategy and its job creation schemes since 1995 arguably pose new questions regarding the state's changes to its immigration policy for foreign migrant workers. In 1995, the government offered incentives to promote industries such as electronics, automated manufacturing, biotechnology and information technology consistent with Malaysia's 'Vision 2020' goal of becoming a developed country by 2020. This goal required continuing dependence on foreign workers and state action to control, direct and regulate labour migration. Concurrently, Malaysia experienced an out-migration of skilled workers in construction and other sectors to Singapore and other East Asian industrialising countries, which offered higher wages. The government subsequently crafted immigration reforms and schemes for admission of high-skilled and low-skilled foreign workers. The immigration schemes for high-skilled workers need not detain us here since there were fewer restrictions on the legal channels for highskilled employment-based immigration and skilled foreign workers (Kaur 2010: 385-397; Kaur 2013: 65-92).

A Special Task Force on Foreign Labour was established as the sole agency responsible for the recruitment of low-skilled foreign workers (excluding domestic workers and shop assistants). Because the Task Force was the sole institution for recruiting and organising the admission of foreign labour, the new policy may be considered a policy of managed migration. The Task Force took over from the Immigration Department the job of processing foreign labour applications, apart from those of domestic workers, who were not considered "formal" sector workers and whose applications continued to be organised and processed by private labour agencies before they were submitted to the Immigration Department. The increasing role of foreign labour in the major economic sectors is detailed in Table 5.2 below. As these figures show, manufacturing soon overtook agriculture as the major employer of foreign labour, although all sectors recorded increases in absolute terms. 
Table 5.2 Proportion of migrant workers in Malaysia's main economic sectors

\begin{tabular}{lccccc}
\hline Sector & $\begin{array}{c}\mathbf{1 9 8 5} \\
\mathbf{( \% )}\end{array}$ & $\begin{array}{c}\mathbf{1 9 9 0} \\
\mathbf{( \% )}\end{array}$ & $\begin{array}{c}\mathbf{2 0 0 0} \\
\mathbf{( \% )}\end{array}$ & $\begin{array}{c}\mathbf{2 0 0 5} \\
\mathbf{( \% )}\end{array}$ & $\begin{array}{c}\mathbf{2 0 0 9} \\
\text { (\%) }\end{array}$ \\
\hline Agriculture* & 50.1 & 37.7 & 24.8 & 26 & 26.1 \\
Manufacturing & 6.9 & 8.8 & 38.1 & 32.1 & 34.6 \\
Construction & 15 & 34.4 & 8.5 & 15.5 & 15.6 \\
Services (non-domestic) & $20.3^{* *}$ & 19.1 & 6.7 & 8.8 & 10.6 \\
Domestic services & & & 22 & 17.6 & 13.1 \\
Total (\%) & 95.3 & 99.5 & 100 & 100 & 100 \\
Total (number) & 212,000 & 441,000 & 807,000 & $1,815,000$ & $1,918,000$ \\
\hline
\end{tabular}

* Includes forestry, fishing and mining

** Includes domestic service

Source: Devadason \& Chan (2010)

The Immigration Department's role was expanded to include the regulation of foreign labour recruitment and the identification of "appropriate" laboursource countries, and to screen the eligibility of sectors and businesses wanting foreign workers. Individual employers and firms wanting foreign workers had to meet conditions that included minimum capital investment and an explicit ratio of local to foreign labour in the workforce (Barden 2006). The government's preferred source countries for recruitment of migrant workers in selected economic sectors are listed in Table 5.3.

Table 5.3 Countries of origin of foreign workers approved for recruitment to Malaysia, 2008

\begin{tabular}{ll}
\hline SECTOR & COUNTRIES \\
\hline Construction & $\begin{array}{l}\text { Philippines (men), Indonesia, Cambodia, Kazakhstan, Laos, } \\
\text { Burma, Nepal, Thailand, Turkmenistan, Uzbekistan, Vietnam, } \\
\text { Bangladesh } \\
\text { Philippines (men), Indonesia (women), Cambodia, Kazakhstan, } \\
\text { Laos, Burma, Nepal, Thailand, Turkmenistan, Uzbekistan, } \\
\text { Vietnam, Bangladesh }\end{array}$ \\
Plantation/ & $\begin{array}{l}\text { Philippines (men), Indonesia, India, Cambodia, Kazakhstan, Laos, } \\
\text { Burma, Nepal, Thailand, Turkmenistan, Uzbekistan, Vietnam, }\end{array}$ \\
Agriculture & Bangladesh \\
Service & All source countries for general worker posts (except India - \\
- Restaurant & cooks only). Restaurants in major towns in Peninsular Malaysia \\
- Laundry & All source countries except India \\
- Cleaning/Sanitation & All source countries except India \\
- Caddy & All source countries except India
\end{tabular}




\begin{tabular}{ll}
\hline SECTOR & COUNTRIES \\
\hline - Resort islands & All source countries except India \\
- Welfare homes & All source countries except India \\
- Cargo & All source countries except India \\
- High tension cable & India only \\
Domestic workers & $\begin{array}{l}\text { Sri Lanka, Indonesia, Thailand, Philippines, Cambodia } \\
\text { India*, Nepal*, Vietnam*, Laos* }\end{array}$ \\
Foreign nurses & Albania, India, Bangladesh, Philippines, Pakistan, Indonesia, \\
& Burma \\
\hline
\end{tabular}

* Included since 2008

Sources: Kanapathy 2006, Kanapathy 2008

The Asian financial and economic crisis of 1997-1998 led to further changes in Malaysia's evolving immigration policy. The crisis triggered a deep recession in the country, which led to a revitalised focus on security issues and overdue reforms in the guest-worker scheme. Data collection on migrant workers to ascertain their legal status was enhanced. The state banned the recruitment of foreign labour in most sectors other than the manufacturing, services and hospitality sectors. It also granted amnesty to Indonesian guest workers and commenced another legalisation programme directed at irregular workers from Indonesia, Thailand, the Philippines, Bangladesh and Pakistan. Because of the large numbers of irregular migrants, additional detention centres were established to 'judicially' detain undocumented migrants. The Task Force was disbanded in March 1997, and foreign labour recruitment was transferred to the Foreign Workers Division of the Immigration Department. The government also tightened immigration regulations and introduced penalties for both employers and workers who breached immigration regulations.

As expected, the 'stop-go' foreign labour employment policy cycle resumed shortly before the end of 1998 when the economy recovered. Foreign workers were again welcomed in Malaysia, and the government also required additional foreign workers to build the state capital at Putrajaya. However, the maximum period for the temporary work permit was reduced from five to three years in 2001 but was predictably restored to the previous five-year maximum period in 2002. This ruling did not include the domestic service sector (Devadason and Chan 2010, p. 5; Table 2, Note). After the fifth year, the foreign workers had to return to their country of origin for a minimum one-year period before seeking reemployment in Malaysia. This stipulation then became an enduring feature of the temporary worker policy. Figure 5.1 show the size and origins of the migrant worker popula- 
Figure 5.1 Malaysia: Foreign workers by country of origin (per cent), 1999-2008

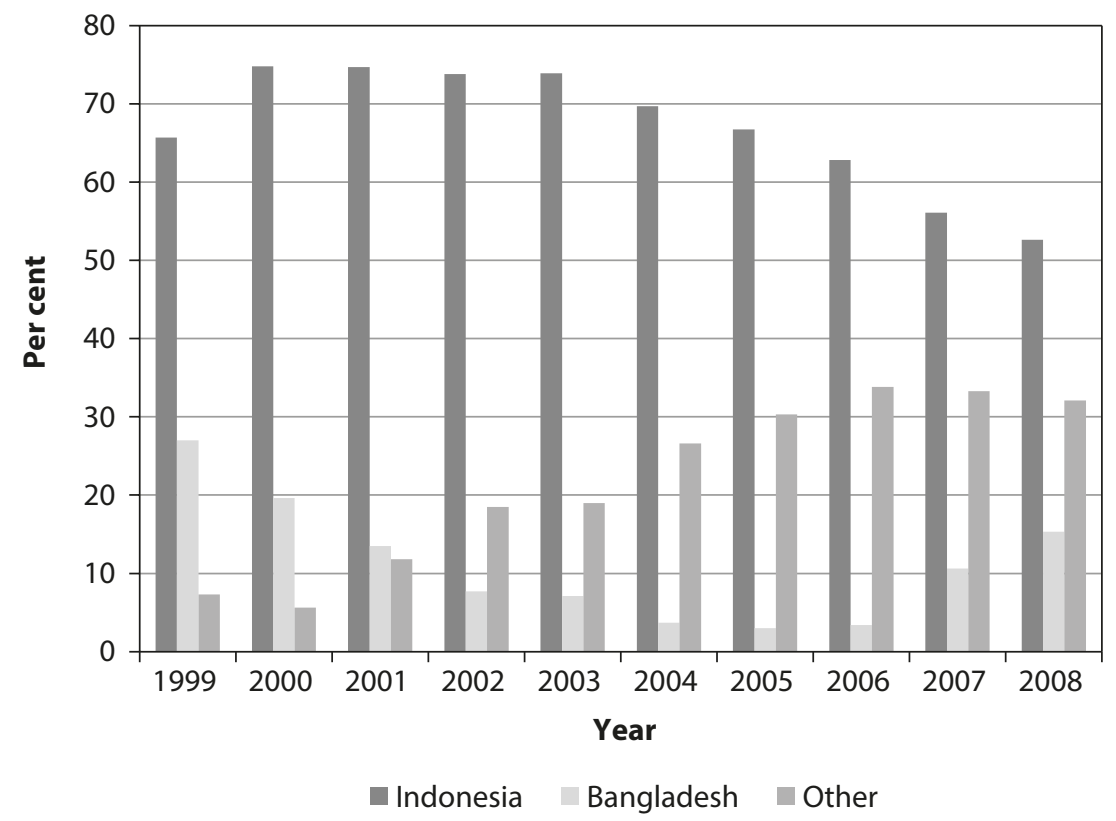

Source: Derived from Ministry of Home Affairs, Economic Planning Unit, Economic Report 2010/11

tion in Malaysia from 1999-2008. It demonstrates the predominance of Indonesian and Bangladeshi migrant workers in the country.

The gendering of labour migration

In 1999, Indonesia established the Directorate for Placement of Indonesian Migrant Workers Overseas to deregulate Indonesian transnational labour recruitment. The directorate was authorised to regulate the placement of Indonesian workers overseas as well as to supervise the licensing of labour recruitment companies (known as Perusahaan Jasa Tenaga Kerja Indonesia or PJTKI). Potential migrants had the option of either directly contacting a PJTKI (located in the cities) or seek out the services of informal labour brokers in their villages. The informal brokers hence played a very important role in recruiting migrants for work abroad. Generally, migrants were recruited from country areas and had to navigate local village, district and provincial intermediaries, who paid their transport costs and provided financial and other support. The intermediaries then delivered migrants to the licensed recruitment agencies (Lindquist 2010: 115-132). The latter 
often worked in collaboration with Malaysian labour contractors to obtain workers for Malaysia. Consequently, the recruitment system was not only time-consuming and exploitative, it also created inequities in migration processes and led to irregular migration to Malaysia.

In 2002, Malaysia arranged for an estimated 600,000 undocumented migrants - the actual figure was believed to be between 600,000 and 1.5 million - to leave without penalty under the amended Immigration Act. The deportation programme caused a humanitarian crisis at one of the departure points at Nunukan, an Indonesian island off the shores of Sabah, where 80 Indonesian migrants died (Ford 2006). Crucially, this event led to greater advocacy and action by Indonesian and international non-governmental organisations (NGOs) on behalf of Indonesian migrant workers, many of whom were trafficked by labour recruitment companies. The Indonesian government subsequently passed new legislation in 2004 (the Overseas Placement and Protection for Indonesian Workers Law) establishing a National Agency for Placement and Protection of Indonesian Overseas Workers (BNP2TKI). This agency was intended to improve the coordination and effectiveness of government ministries and agencies and address human trafficking. Additionally, the Indonesian government also imposed a ban on the recruitment of women migrants for Malaysia. Indonesia and Malaysia also signed a Memorandum of Understanding (MOU) making it obligatory for Malaysian employers to use licensed Indonesian labour-recruiting agencies to recruit (male) Indonesian workers. Other issues included revised age eligibility requirements for migrant workers and the obligation of pre-departure training and better wages (Tirtosudarmo 2011).

Indonesian women workers' circumstances in Malaysia was reported by Human Rights Watch in its 2004 report highlighting the Indonesian and Malaysian government's lack of concern for this category of migrants (Help Wanted: Abuses Against Female Migrant Domestic Workers in Indonesia and Malaysia). The inherent unequal gender hierarchies in both countries meant that domestic workers had no avenue for redress and were susceptible to abuse by employers. The Indonesian state also ruled that only Indonesian labour-recruitment companies were allowed to recruit Indonesian domestic workers for overseas employment (IOM 2010:12). The domestic workers' recruitment was thus linked to a "personal" and "sponsored-immigration" procedure. A Malaysian employer who sought to employ a domestic worker had to seek the services of a certified Malaysian domestic worker recruitment agency. The agency then initiated a 'search' order with a counterpart Indonesian recruitment agency which offered a selection of applicants to the client. After selection, the prospective employer was required to 
pay all training, visa and travel costs up front. Thus both the Indonesian and Malaysian governments allowed Indonesian brokers and Malaysian domestic worker agencies to handle all aspects of domestic workers' immigration. Following a series of well-publicised abuse cases, Malaysia and Indonesia signed an MOU in May 2006 that specified a standard contract for Indonesian domestic workers in Malaysia. Although the pay scale was revised upwards, the withholding of salary continued, and employers would retain the domestic workers' passports to prevent them from escaping. The issue of a minimum wage was not resolved, and employers refused to grant a weekly day off to domestic workers (Kaur 2007).

At the same time, additional punitive measures were approved to thwart irregular migration. Two particular articles of the Immigration Act, Articles 6 and 51, are used to detain and charge irregular migrants. Article 6 of the Act states the grounds for legal entry, and any person not meeting these grounds will be severely punished. Article 15 defines illegal entry as 'unlawful entry or presence in the country' or overstaying in the country. Errant employers employing more than five undocumented workers were subject to fines, imprisonment and physical punishment (Sreenevasan 2006). The government amended the Immigration Act in 1997 and 2002 to remove ambiguities and tighten regulations and further increased the penalties for both employers and workers in breach of immigration regulations. The amended legislation made it a criminal offence for foreign workers to work without a work permit or visa and introduced punitive judicial measures, including the caning of workers. The Immigration Act allows the indefinite detention of illegal migrants pending their deportation. Thus undocumented persons in Malaysia, whether they are alleged illegal migrant workers or asylum seekers, can face a jail sentence of up to five years, a fine of RM 10,000 (USD 2,60o) and six strokes of the cane (Kaur 2006).

Malaysia continued with its periodic expulsions, announcing in July 2004 that it planned to send away more than one million undocumented workers by the end of 2005 (Amnesty International 2010). In 2005, the government enlisted the services of a non-government agency, the Ikatan Relawan Rakyat Malaysia (Rela) or Peoples' Voluntary Corps, to assist its operation against irregular migrants (including refugees and asylum seekers). Rela was formed in 1972 to assist, maintain and safeguard peace and security in the country and to undertake community projects. Volunteers were trained and were 'expected to act against virtually all types of anti-government activity' and promote government objectives (Funston 1980: 270). The state had utilised Rela's services to restrain the Vietnamese boatpeople in the 
1970 and 1980s, and the agency's new duties included instructions to 'stop, search and demand documents, arrest without a warrant, and enter houses or premises believed to house irregular migrants' (Suaram 2006: 120-1).

Unsurprisingly, the 2005 regularisation exercise also resulted in labour shortages and necessitated further reforms in foreign labour recruitment. The government then established a One-Stop Centre for the recruitment of migrant workers in 2005 in the Immigration Department (in the Ministry of Home Affairs) to provide oversight of and to centralise foreign labour recruitment. The earlier policy of employers independently liaising with recruitment agencies in the source country (Indonesia) was discontinued. Henceforth employers wanting to recruit temporary guest workers had to apply for approval from the Ministry of Home Affairs and the One-Stop Centre. Concurrently, the Malaysian government announced that foreign workers would be treated "in accordance with the provisions of International Labour Organization (ILO) conventions".

Most economists agree that the government's policy of maintaining the country's export competitiveness based on cheap foreign labour has resulted in Malaysia being caught in the middle-income trap. Concurrently, Malaysia's weak governance structures have resulted in the marginalisation and vulnerability of low-skilled migrant workers, whose legal status is insecure and whose freedom to move around the country is restricted. A major flaw is the large number of ministries and government agencies involved in the recruitment process. The labyrinth of jurisdictions and the poor coordination between ministries and departments make it almost impossible for workers to seek redress and justice. Consequently, migrant workers who have to remain in the country following unlawful termination of their employment become undocumented and face incarceration and physical punishment. Employers retain their passports, making them vulnerable to being caught by Rela and placed in detention camps. As Ramachelvam (2008) notes, foreigners comprise 33 per cent of the prison population, despite the fact that they commit only two per cent of the crimes. The vast majority of them are there on immigration-related offences. Since immigration violations are considered civil matters, these workers may be imprisoned without any rights and no guarantee of a speedy trial. The government has also introduced a biometric identification system (I-Kad) to ensure that foreign workers who have broken the law do not reenter Malaysia under a different identity.

The latest objectionable aspect of Malaysia's foreign labour employment policy is the labour outsourcing system, which has reduced the meagre benefits provided to migrant workers. Outsourcing has been accepted, 
despite mounting criticism from advocacy groups. Most Chinese entrepreneurs have chosen to operate small and medium-sized enterprises in order to evade the Industrial Coordination Act's employment quota, which requires that Malays make up at least 30 per cent of the workforce in businesses above a particular size threshold (Hill 2012). Additionally, Malaysia's share of Southeast Asian foreign direct investment flows has dropped from 35 per cent in 1980 to only 13 per cent in 2008 (Migration News January 2010). The government, in its efforts to encourage further private sector initiatives and increased investment, endorsed a 'new' model of labour brokerage or outsourcing arrangements after 2005 for firms employing fewer than 50 workers. The new labour model has coincided with the push by multinational companies, such as Nike, to invest in small manufacturing firms producing clothes and sports shoes that carry their brand names. Specialised farms utilising the same labour model have also mushroomed in the country. The state has promoted the recruitment model because workers hired by labour-hire companies are not included in the quotas assigned to the different sectors, thus giving more leeway to the state and employers.

Essentially, workers hired under this system have to 'pay' for the privilege of employment. The Malaysian government has argued that the outsourcing system is superior to recruitment via agencies, as the intermediaries, who charged 'exorbitant' fees, no longer have a role in the recruitment process. The outsourcing system is effectively a new variant of contract labour. Workers are brought into the country on calling visas issued on behalf of outsourcing companies (through arrangements with labour brokers in the sending countries). Although legally obliged to provide specific jobs for the workers they bring in, the labour-hire firms function as speculative labour contractors, moving workers around to get the best deal for the firms. Effectively, the right to a guaranteed employment relationship between workers and employers until retirement has been replaced with short-term or limited duration contracts (Hector 2012a). The labour-hire firm also functions as the de facto employer. It has been alleged that the outsourcing system has transformed migrant workers into bonded labour (Ramachelvam 2008), and horror stories of their exploitation have been reported in the media (Tenaganita 2007; interview with Irene Fernandez July 2011).

Despite the government's efforts to control the numbers of irregular migrants, the outsourcing system resulted in an expansion of unauthorised migrant workers. The MTUC reported in 2007 that the activities of the labour-hire firms 'has worsened the problem of human trafficking' in Malaysia since they had brought in as many as '500 workers each' who were then 'sold' or outsourced' (Humantrafficking.org 2007). Undoubtedly, 
the government-sponsored outsourcing recruitment policy has resulted both in the exploitation of workers and in them becoming 'irregular'. It is also generally known that workers' irregularity occurs in conjunction with flexible labour markets and in an environment where companies unable to remain in business without the low-cost flexibility resort to sacking workers en masse.

The government's policy of roundups and amnesty, followed by the regularisation of irregular migrants, has now become a recurrent cycle. The 2011-2012 programme is the largest comprehensive policy in the ongoing cycle. It has been branded the ' 6 P Bersepadu legalisation programme' and comprises six essentials: pendaftaran (registration), pemutihan (legalisation), pengusiran (deportation), pemantauan (monitoring), penguatkuasaan (enforcement) and pengampunan (amnesty). The government's 'exercise' is intended to provide accurate statistics on migrant workers in the country (estimated at about two million) and to register and regularise undocumented workers (believed to be a further two million). Irregular migrants are required to return to their own countries and go through official recruitment procedures before they are allowed to return to Malaysia. Following registration procedures, workers' particulars are entered into the government's biometric system to enable 'better control over foreign labour' (The Star 2011a, 2011b). In implementing this strategy of offering irregular migrants amnesty and the opportunity to become regularised in a more systematic manner (that is, without being held in overcrowded detention centres), Malaysia appears to be emulating some aspects of policies in the United States and the European Union. Significantly, despite initially criminalising irregular entry and imposing harsh sentences on the convicted migrants, the regularisation policy has created a larger legal labour pool for the state, which has consequences for both domestic and international investment in the country.

Unauthorised migrants are required to pay a fine and a special visa fee to receive a biometric ID. After registration, the migrants may leave Malaysia without penalty, or obtain work permits. As the home ministry secretary-general stated, in May 2012 the government collected nearly RM 1.5 billion in levies, while the programme delivered 1,136,598 new 'regularised' foreign workers (The Star 2012). According to a 2013 report citing the deputy home minister, there are "some 2.6 million" registered foreign workers in Malaysia who possess a valid employment permit issued by the Immigration Department. He affirmed that "over 1.3 million illegal immigrants were registered" but emphasised that the "actual number of illegal immigrants could not be ascertained" since "most of them had registered under the $6 P$ 
Bersapadu legalisation programme." A further 9,630 illegal immigrants were also deported. Crucially, the new I-Kad will not only be colour coded to identify the specific 'permitted' occupation of the holder, it will also assist the state 'in locating workers' (The Star 2013).

Malaysia is a party to 28 International Labour Organization (ILO) conventions, including the Migration of Employment Convention (Revised) 1949 (C97) pertaining to the equal treatment of migrant workers. Malaysia's ratification of this convention means it should 'apply treatment no less favourable than that which applies to their own nationals in respect to a number of matters, including conditions of employment, freedom of association and social security', as stated in the convention. Restricting the freedom of movement and association of foreign workers is an outright violation, and Malaysia's management of its urban spaces for irregular migrants, whether they are refugees or trafficked individuals, is judged to be the worst in the region. Malaysia remains a destination, a source and transit country for men, women and children who are subjected to conditions of forced labour (US Department of State 2012).

\section{Refugees and others: Neither needed nor tolerated}

In its 2007 Trafficking in Persons Report, the US State Department placed Malaysia in Tier 3, assessing it as failing to make efforts to comply with minimum standards for the elimination of human trafficking. Following publication of this report, the US Senate Committee on Foreign Relations carried out its own investigations into allegations of trafficking and extortion of Burmese irregular migrants in Malaysia and along the Malaysia-Thai border. Predictably, the Committee's report not only confirmed the trafficking and human rights abuses, it also alleged that Malaysian immigration officials, police and Rela personnel were involved in the trafficking trade (US Senate Committee on Foreign Relations 2009; see also Tenaganita 2008). Although Malaysia introduced new measures to combat human trafficking, including taking action against errant police and immigration officials and instigating a new Anti-Trafficking in Persons Act in 2007, it was placed in Tier 3 once again in 2009. According to a leading human rights advocate, 'the [Malaysian] government seems to have lost its way and abandoned its duties and obligations to improve the rights and welfare of persons, workers and their families ...' (Hector 2012b).

In 2005, the Malaysian Attorney-General ordered the Malaysian government to cease prosecuting refugees with UNHCR recognition or documents 
(Suaram 2008), but the 2009 World Refugee Survey (USCRI 2009) listed Malaysia, together with South Africa and Gaza, as one of the ten 'worst places for refugees'. Amnesty International's 2009 State of the World's Human Rights report also mentioned beatings endured by refugees and deplorable conditions at Malaysia's immigration detention centres. Then, in 2011, Malaysia undertook a joint exercise with the UNHCR to register refugees and asylum seekers in the country in a much-publicised attempt to provide better protection for them. This programme involved about 94,80o refugees and asylum seekers whose status had been confirmed by the UNHCR. It was initiated to reassure the international community that the 'refugee and asylum seeker category' of undocumented migrants would be dealt with independent of the $6 \mathrm{P}$ programme. According to a media report, this issue surfaced after the Malaysia-Australia refugee swap deal was shelved (The Star 2011c) (see Chapters 8 and 9 in this volume). It was perhaps due to this action that Malaysia rose slightly to the Tier 2 Watch List in the US State Department's 2012 Trafficking in Persons Report. But in a recent speech, the home ministry secretary-general remarked that Malaysia's ranking could possibly fall to Tier 3 in the 2013 Report and "will reflect negatively on ... [Malaysia] and give a bad image to ... the country" (Malaysia Today, 23 October 2013). 


\title{
6 Labour migration flows and regional integration in Southeast Asia
}

\author{
Marshall Clark
}

\section{Introduction}

This chapter will explore recent tensions in the Indonesia-Malaysia bilateral relationship and the issue of migrant workers, particularly Indonesian migrant labour in Malaysia. The first part of this chapter examines the contours of regional integration in Southeast Asia. The second part examines why, in the receiving country of Malaysia, Indonesian migrant workers are regarded as a national security threat. The third part will extend this discussion by examining the way in which the issue of Indonesian labour migration can be more accurately categorised as a human security issue, rather than, in the case of Malaysia, a national security issue. The difference in categorisation arises because Indonesia appears more determined than Malaysia to seek a regional solution to the migrant labour issue. The differing emphasis, it will be argued, is to some extent a reflection of Indonesia's successful transition to democracy. The final section of the chapter will address the argument that the transformation in Indonesia's regional behavioural norms has not necessarily triggered a deepening of regional integration with better social outcomes for migrant workers.

The issue of labour migration flows between Indonesia and Malaysia can be approached in a regional integration theoretical framework that examines the diffusion of democratic norms throughout the region. Many scholars have examined the impact of regional organisations on democratic transition and the consolidation of new democracies (see, for example, Pevehouse 2005; Schimmelfennig \& Sedelmeier 2005; Featherstone \& Radaelli 2003). Less research has been conducted on the influence of democratisation on regional integration and the development of regional understandings that can strengthen human rights protections for the most vulnerable in society, such as migrant workers. It is widely assumed that a pluralistic and democratic political order provides the best conditions for non-government groups to thrive and influence government decisions on regional decision-making. However, democratisation does not necessarily translate into greater regional integration and the strengthening of migrant worker protections. For Southeast Asia, a key lesson from Europe is that, on 
the one hand, democracies are more likely to take part in regional integration projects than autocracies, but, on the other hand, democracies may also be averse to the deepening of regional integration (see Rüland 2009).

An alternative explanation, with similar conclusions, can be derived from Snyder's 'nationalist elite persuasion' hypothesis (Snyder 2000). According to Snyder, new democracies are particularly susceptible to nationalist appeals, which can hamstring efforts to develop deeper regional integration. Two factors can account for this phenomenon: the historical legacy of the colonial experience and the mode of democratic transition. Rüland (2009) explores Snyder's approach in the context of Indonesia and the problematic relationship between its democratic consolidation and its regional behaviour. According to Rüland, the Indonesian case is particularly illuminating, as both the colonial experience and the mode of democratic transition have ensured that Indonesia's democracy is susceptible to a strong nationalist rhetoric. In relation to the impact of colonialism, many observers have commented on the strength of Indonesian nationalism, which first emerged after several centuries of often-harsh Dutch colonial rule (see, for instance, Anderson 1991). The fight for independence was bloody and deeply traumatic, with a great deal of human and material loss. As a consequence, nationalist ideology tends to be deeply entrenched in the collective memory. Indonesia's strong nationalist orientation has also meant that in the postcolonial era, all political parties or non-government groups have tended to espouse a nationalist rhetoric, even parties representing political Islam (Rüland 2009). In the post-authoritarian era, Indonesia's foreign policy is also squarely framed by a strong nationalist rhetoric (Clark 2011). Subsequently, Indonesia's bilateral relations with its immediate neighbours, such as Malaysia, are often subject to populist appeals and fear-mongering amongst competing political elites (Usman \& Din 2009; Efantino \& Arifin 2009; Susilo 2009).

\section{Regional integration and Indonesia-Malaysia relations}

Moves towards developing regional integration or, rather, more formalised intra-regional co-operation on cross-national issues such as labour migration are often limited by the need to reconcile differences in history, culture, religion and politics (see Fawn 2009). As a result, understanding domestic cultural and political factors in regionalism, while necessary, is complicated by both elements being both a major driving force and an obstacle to regionalism. Democratisation - or the lack thereof - is one such factor. 
For example, while the Association of Southeast Asian Nations (ASEAN) has been relatively successful in the fields of security and economics, in terms of democratisation, Southeast Asia has long held a reputation of being the 'most recalcitrant region' according to Emmerson (1995: 227), steeply resisting both democratising processes and their comparative analysis (Case 2009). Although Emmerson (2008) now looks on democracy's advance in Southeast Asia with greater optimism, there is very little agreement within the region on cultural and political issues, which underpin processes of democratisation and governance (Jetschke \& Rüland 2009; Dösch 2008a). Some of these issues include the environment, human rights and labour migration, all of which are important human security concerns (Katsumata 2009; Dösch 2008a; Arifianto 2009). Issues such as trans-border haze pollution and population movements within Southeast Asia, which can also be regarded as regional problems, also have an impact on regional integration (Caballero-Anthony 2008; Tay 2008).

Understanding the link between democratisation and the differing political attitudes of member countries of ASEAN, such as Indonesia and Malaysia, is also crucial for understanding the degree of regional integration in the region. Yet domestic politics, and for that matter, domestic political attitudes, are often neglected as a key element of understanding Southeast Asian regional dynamics (Dosch 2008b). In regards to labour migration, the contrasting attitudes of Indonesia and Malaysia can to some extent be explained by the varied levels of diffusion of democratic values at the domestic level, which then flows through to the regional level of decision-making. In practice, more democratic countries such as Indonesia have been more active in introducing liberal agendas to ASEAN diplomacy, including calls for 'political reform' and greater involvement of more non-governmental actors in regional decision-making (Katsumata 2009; Sukma 2008, 2009). For Indonesia, the challenge lies in developing regional policies to address the key human security issues such as the provision of migrants' rights in the sending and receiving countries in the region.

At the height of Indonesia's democratic transition period, say between 1998 and 2004, its ASEAN neighbours were becoming increasingly circumspect. Besides regional annoyances, such as the perennial smoke rising from Indonesian forest fires spreading to neighbouring countries (Tay 2008), Indonesia's self-styled role as a 'normative power' was regarded by fellow ASEAN members as a dual threat: 'it nurtures apprehension about Indonesian hegemony in ASEAN and, especially in non-democratic ASEAN member states, fears of an erosion of domestic political stability' (Rüland 2009: 379). Yet in recent times, almost all nations in the region have ben- 
efited from Indonesia's transition to democracy, this democracy being to some extent has been 'projected' onto the region (Sukma 2008, 2009). On the one hand, Indonesia has been relatively frank and robust in its criticisms of ASEAN, urging its members to seriously consider the benefits of 'political reform', widely regarded as a euphemism for democratisation. On the other hand, Indonesia has rediscovered a strong international orientation above and beyond the immediate Southeast Asian region. In 2010 in an Independence Day speech, the President of Indonesia, Susilo Bambang Yudhoyono (SBY), declared that Indonesia is now ready to embrace an 'all directions' foreign policy where Indonesia can achieve its aim of 'a million friends, zero enemies' (sejuta kawan, tanpa musuh) (Yudhoyono 2010). Paving the way for these statements was the country's success in its role as Southeast Asia's sole representative on the influential G20 and its hosting of the 2009 United Nations Climate Change Conference. Indonesia has earned itself great kudos for establishing the annual Bali Democracy Forum, with its goal of nurturing the practice of democracy and good governance among the countries of the Asia-Pacific region. Indonesia has also given much greater consideration to its self-perceived 'global obligations', such as the adoption of international human rights standards, and has been increasing its contributions to global efforts to mitigate climate change and support more sustainable paths to development. Indonesia also pressed ahead with its ongoing involvement in the global war on terrorism.

Proving the Indonesian saying that 'one can whistle while one walks' (bersiul sambil berjalan), Indonesia's more global foreign policy orientation has not come at the cost of its commitment to the immediate region. Indonesia's support for ASEAN has remained steadfast and, if anything, has strengthened. This was particularly manifested during Indonesia's successful chairing of ASEAN in 2011, when Indonesia enjoyed a number of notable successes, namely as a mediator in the escalating border tensions between Thailand and Cambodia and, after several years of mentorship, overseeing Burma's initial steps towards democratic reform. Relations between the leaders of Indonesia and Burma are now quite close, and the Indonesian media proudly claims that Burma's recent steps towards democratic progress came about almost exclusively as a result of the influence of ASEAN, which was sparked into action by Indonesia's guiding hand (see, for instance, Riady 2012).

Considering Indonesia's preeminent role in ASEAN, examining Indonesia's testy relationship with Malaysia is useful for a number of reasons. It has often been argued by scholars studying the international politics of Southeast Asia that Indonesia and Malaysia are cornerstone members 
of ASEAN and are thus at the very heart of questions of regional security (Liow 2006). Furthermore, it has often been acknowledged along the corridors of power in ASEAN that, together with Singapore, Indonesia and Malaysia form the 'security core' of Southeast Asia. The Indonesia-Malaysia bilateral relationship also reveals a great deal about the domestic politics of each nation. In relation to this, it is worth pointing out that the IndonesiaMalaysia bilateral relationship has seldom been harmonious, with tensions sometimes breaking out into open conflict (Weiss 2010). This should come as no surprise. Indonesia is the largest Muslim country in the world with a population of over 240 million, whereas Malaysia is a small country and has a population of about 30 million. Indonesia is courted by the United States and Australia and, as mentioned earlier, is a member of the prestigious G2o. Although according to the Freedom House, Indonesia is more democratic than the soft-authoritarian Malaysia, it is also much poorer than the latter. This has caused many Indonesians, particularly those who have worked in Malaysia, to feel envious of Malaysia's economic success (Bayuni 2010). Yet Malaysia's economic success is highly dependent on migrant labour, and Indonesians constitute approximately 65 per cent of all low-wage migrants in Malaysia (Chin 2008: 290). In this regard, Malaysia has a record of mistreating Indonesian migrant workers, and many Indonesians resent Malaysia's policies towards Indonesian workers (Arifianto 2009; Weiss 2010; see also chapter 5 of this volume).

In recent years, growing anti-Malaysia resentment amongst the Indonesian population has led to a widespread public outcry against Malaysia as well as calls to temporarily halt the flow of migrant workers from Indonesia to Malaysia (Lazuardi 2009; Efantino \& Arifin 2009; Usman \& Din 2009). Adding more fuel to the fire, in 2008 and 2009 the Indonesian media claimed, incorrectly, that Malaysia had lodged intangible cultural heritage claims with UNESCO for shared Indo-Malay cultural forms including textiles, songs, dances, cuisine and traditional musical instruments (Suditomo, Pudjiarti \& Dimyathi 2009). In a classic tit-for-tat, rumours emerged that the melody of the Malaysian national anthem was based on the tune of an old Indonesian song (Rizal \& Rafiq 2009). There was also the charge that a recent Malaysian tourism campaign was based on footage of Indonesian cultural forms. It could be argued that the recent testiness of bilateral relations between Indonesia and Malaysia is overblown. For many, the deeper historical roots to the Indonesia-Malaysia enmity lie in the events of 19631966 when Indonesia launched its anti-Malaysia policy of Confrontation (Konfrontasi), involving a series of confrontational policies and actions in response to the formation of the Malaysian nation-state (Mackie 1974; Jones 
2002). Others have highlighted the ongoing border dispute over Ambalat, the oil-rich area off the coast of Malaysia's Sabah State and Indonesia's East Kalimantan, as a major source of conflict (Liow 2006; Efantino \& Arifin 2009). Indeed, Rüland claims that the Ambalat territorial dispute is currently the most vexing problem in Indonesia-Malaysia relations (Rüland 2009: 392). But the Ambalat controversy and the cultural heritage spats are most probably mere symptoms, albeit serious issues in their own right, of an underlying issue: the treatment of Indonesian migrants as a security threat to Malaysian society. This issue, more than any other, has negatively affected the relationship between migrants, citizens and governments of Indonesia and Malaysia. It also reveals a great deal about both the domestic politics and regional orientation of the two countries, with important implications for the relationship between democracy and regional integration. As we shall see, Eurocentric regional integration theory, which tends to highlight the causal links between democracy and regional integration and vice versa, is not easily transferable to the Southeast Asian context.

\section{The world's second biggest transnational migration centre: Southeast Asia}

Within the last few decades, transnational labour migration has become a contentious political issue in many countries across the globe, none more so than in the United States, where the border with Mexico is the busiest transnational migration centre of the world. The second biggest is Southeast Asia, with Malaysia as the epicentre. Migrant workers now constitute a fifth of the total workforce in Malaysia. Moreover, Malaysia is one of the world's top receiving countries for undocumented migrants, second only to the United States (Arifianto 2009). Estimates of the population of undocumented migrants range from two to four million people (see chapter 5 in this volume). As Chin (2008: 286) observes, if added to the number of documented workers, the transnational migrant population in Malaysia may well constitute nearly half of the total labour force in the country.

Existing studies on transnational migration in Southeast Asia have tended to view it primarily from the perspectives of labour, human rights or gender. In recent years, there is a small yet growing body of work on labour migration as a security problem between Indonesia and Malaysia, with an emphasis on how Malaysian politicians have shifted their treatment of Indonesian migrants from a policy of tolerance to one that considers them a security threat against Malaysian society (Chin 2008; Arifianto 2009; Liow 
2003). This chapter takes these few studies analysing labour migration from a security perspective one step further by suggesting that, coupled with differing levels of democracy in the region, the labour migration issue in Southeast Asia has important implications for regional integration.

The recent securitisation of Indonesian migrant workers in Malaysia has emerged as a bitter surprise to many Indonesians, low-wage workers and politicians alike, as for much of the early twentieth century Indonesian workers were welcomed in Malaysia, mainly because they shared the racial, linguistic and religious background of the Malays (see, for example, Raharto 2007; Ford 2006; Arifianto 2009; chapter 5 in this volume). After independence, the Malaysian government continued to encourage the migration of Indonesian workers to Malaysia. Because Indonesians were perceived as being able to assimilate easily into Malaysian society, many thought that the Malays' electoral strength could be strengthened over that of other Malaysian ethnic groups (see chapter 5 in this volume). By the late 1990s, there were approximately two million Indonesian migrants working in Malaysia, over half of whom were undocumented.

From the early 1970s, economic factors went hand in hand with the political motivation behind Indonesian migration to Malaysia. As manufacturing grew, Malaysia experienced a wave of urbanisation, which gave rise to labour shortages in the agricultural sector. Overseas workers, mainly from Indonesia, helped fill the labour shortages, first in the agricultural sector and then in the manufacturing sector in the late 1970 s and 1980 s. Since the Asian economic crisis, Malaysia has experienced an immense construction boom, especially in and around Kuala Lumpur. As Kaur has discussed in chapter 5 , Indonesians and other migrant workers were essential in providing the labour to keep up with this demand. However, with the increase in the number of Indonesians entering Malaysia over the years, particularly in the years immediately after the Asian economic crisis, fears grew that these Indonesian migrants would significantly disturb or even rupture the fabric of Malaysian society. The Malaysian government and media increasingly highlighted the fact that the influx of Indonesian labour into Malaysia had coincided with an increase in crime rates, particularly in the late 1990s. Unfortunately, Malaysia's increasing intolerance of the criminal activities of 'illegals' has led to much social prejudice against legal Indonesian workers as well.

In the last decade, the Malaysian media and government in particular have become more vitriolic in their attacks on Indonesian migrant 'troublemakers' (see, for example, Raharto 2007; Ford 2006; Arifianto 2009). Consequently there has been a sharp turnaround in policy since 2001, with 
a marked anti-Indonesia stance. In 2001, the Malaysian government enacted a new Immigration Act, and the mass deportation of undocumented foreign workers began, with almost 400,000 Indonesian workers being forcibly repatriated. The 'Hire Indonesian Last Policy' was also introduced. Following the 9/11 terrorist attacks and the Bali bombings of 2002, there were growing fears that the illegal Indonesian migrant worker network could provide yet another channel of Islamist terrorism. By 2002, Indonesian workers in Malaysia had become demonised as regular perpetrators of crimes and potential perpetrators of terrorist activities, all of which, according to Malaysian media and political discourse, threatened Malaysian national security (Arifianto 2009). In numerous interviews with Indonesian migrants and migrant workers in June and July 2010, it became clear that Indonesians were being treated as second-class citizens in Malaysia. To this day, they continue to be seen by Malaysians as the so-called Indonesia security threat.

\section{Indonesia's desecuritisation of the migrant labour issue}

Malaysia's securitisation of the Indonesian labour migrant issue has been greeted with dismay in Indonesia. Numerous protests have been held outside the Malaysian Embassy in Jakarta, criticising Malaysia for its degrading treatment of Indonesian workers. Malaysian flags have been burned and Jakarta newspaper headlines have reminded Kuala Lumpur of the dangers of a new Konfrontasi, referring to the armed conflict between Indonesia and Malaysia over North Borneo from 1963-66. In 2009 a large group of preman (pseudo-militia) in Jakarta declared an invasion on Malaysia, accompanied by sweepings against Malaysian citizens in the city. Indignant Malaysians responded to Indonesia's aggressive stance by referring to Indonesians with the pejorative and derogatory term 'Indons', which is perceived by many Indonesians as the equivalent of referring to African Americans as 'negroes'. As Arifianto (2009) observes, this term sets Indonesians apart as a separate and inferior ethnic group compared with the Malays. Even worse, Malaysians have coined terms such as Indonesial or Indonesialan (where the Malay word sial or sialan - damn or damned - added to Indonesia means 'damned Indonesian(s)'). In Indonesia, the term Malingsia (a pun combining two words, maling and Malaysia, which can be glossed as 'Mal-Thief-sia') has also stormed into the popular consciousness. It is in this context that three books promptly emerged on the shelves of Indonesian bookstores in 2009: Ancaman Negeri Jiran: dari “GANYANG MALAYSIA” Sampai Konflik 
Ambalat (The Threat of a Neighbouring Country: From 'Crush Malaysia' to the Ambalat Conflict); Ganyang Malaysia: Hubungan Indonesia-Malaysia Sejak Konfrontasi Sampai Konflik Ambalat (Crush Malaysia: IndonesiaMalaysia Relations Since the Konfrontasi to the Ambalat Conflict), and Maumu Apa Malaysia? Konflik Indo-Malay dari Kacamata Seorang WNI di Malaysia (What do you Want, Malaysia? The Indo-Malay Conflict from the Perspective of an Indonesian Migrant Worker in Malaysia) (Lazuardi 2009; Efantino \& Arifin 2009; Usman \& Din 2009).

More recent yet no less inflammatory are Taufik Adi Susilo's Indonesia vs Malaysia: Membandingkan Peta Kekuatan Indonesia \& Malaysia (Indonesia vs Malaysia: Comparing the Strengths of Indonesia and Malaysia) and Wawan H. Purwanto's Panas Dingin: Hubungan Indonesia-Malaysia (Hot and Cold: Indonesia-Malaysia Relations), both published in 2010. A rare Malaysian perspective is documented in Karim Raslan's 2010 book Ceritalah Indonesia (Telling the Indonesian Story).

The popular jingoistic imagining of Malaysia as racist and ungrateful, as described in the books above, has not resulted in Malaysia emerging as a threat to Indonesia's national security. Of course, in response to the latest Ambalat cross-border incursion, some politicians reportedly joined the gerakan ganyang Malaysia (movement to 'crush' Malaysia). Others such as Chozin Chumaidy (PPP), Jeffrey Massie (PDS), Permadi (PDI-P), Yusron Ihza Mahendra (PBB) and Soeripto (PKS) recommended the use of force should diplomatic means not lead to solutions acceptable to Indonesia. Others demanded that the Malaysian ambassador be recalled. President Susilo Bambang Yudhoyono pointedly stated: 'We will not sacrifice our sovereignty, our rights and our territory' (Rüland 2009: 393). Yet at the same time he urged restraint, despite the heated public debate. Both sides subsequently expressed their firm intention to resolve the Ambalat dispute peacefully and in line with established ASEAN norms of conflict resolution. The Indonesian navy took steps to de-escalate the tensions in the area, and the foreign ministry stepped up efforts to enter into negotiations with the Malaysians. Apparently, even fourteen rounds of government negotiations could not defuse the conflict (Rüland 2009: 393). Nevertheless, Indonesia's overblown reaction to Malaysia's provocations is probably little more than an expression of hurt pride, albeit combined with a strong dose of nationalist sentiment.

Indonesians are keenly aware of their role in Malaysia's development and industrial success, and Malaysia's treatment of migrant workers has not been appreciated in Indonesian circles, particularly because Indonesians expect some measure of sympathy from their Malay counterparts who 
are widely regarded as bangsa serumpun (of the one tree or racial stock) (see chapter 5 in this volume). As a result, the harmonious gotong royong (mutual help) spirit that defined relations between the two countries in the early years after Konfrontasi seems to have disappeared (Liow 2006). For many Indonesians, the persaudaraan (familial or sibling) relationship often mentioned by politicians from both countries and the awareness that both are fellow members of ASEAN seem not to have ensured any extra effort from Malaysia (Arifianto 2009). Considering that the two 'kin states' have long been regarded as 'blood brothers', Indonesia expects Malaysia to show much greater sensitivity and even deference to its much larger neighbour (Liow 2006). Although this is patently not forthcoming, it would be wrong to suggest that Indonesia has 'securitised' Malaysia. Instead, if anything, Jakarta has tended to 'desecuritise' the situation by pulling back from foreign-policy brinkmanship and focusing on what many politicians regard as the real issue - the human security of Indonesian workers in Malaysia. It is for this reason that the heated cultural contestations between the two countries, as well as the ongoing border incursions, have been quite easy for the Indonesian government to ignore.

Instead, the Indonesian government has focused on government-togovernment negotiations, developing bilateral agreements and the possibility of enlisting regional intervention. In terms of the former solution, a great deal of tension over the migrant worker issue dissipated after the breakthrough bilateral agreement of 2004, which imposes a minimum wage for Indonesian migrant workers (Arifianto 2009). It also provides procedures to recruit Indonesian migrant workers and requires employers of migrant workers and the brokers who brought them to Malaysia to pay for their transportation costs to and from Malaysia. Agreements of this type have been criticised by NGOs and activists, who argue that there are many shortcomings and many unaddressed issues. According to Alex Ong, the Malaysia country director of Migrant Care (an NGO fighting for the rights of Indonesian migrant workers in Malaysia), these agreements are mere token gestures, and Indonesian migrant workers remain as disempowered as ever (Ong 2010). Yet when Indonesian citizens experience problems in the Middle East, references are often made to the fact that little can be done for them via official channels (Bangun 2010). Effectively, the government's consistent argument is that a form of bilateral memorandum of understanding (MOU) is needed. Indonesia's MoU with Malaysia, modest as it is, is considered best practice.

Critics have pointed out that these forms of agreements, accords and MOU are not perfect, as many workers, particularly undocumented work- 
ers, continue to be mistreated, beaten, threatened, exploited and deported on a daily basis (Bangun 2010). Moreover, the Indonesian government has proven that it is prepared to forego considerable remittance earnings from migrant workers, estimated to be USD 7.1 billion in 2010, by enforcing moratoria on the sending of migrant workers until their rights and conditions are significantly improved in the receiving country (Hamzirwan 2010). Demonstrating its willingness to take a stand, the Indonesian government enforced a moratorium on Indonesian migrants travelling to work in Malaysia between June 2009 and April 2010. This was used as an opportunity for Jakarta to lobby Kuala Lumpur to ensure more humane treatment of Indonesian workers, particularly in the informal sector, such as domestic maids and helpers. Subsequently, before the moratorium was lifted, a bilateral accord aimed at improving the conditions of Indonesian migrant workers was signed (Balanta Budi Prima 2010). This agreement formalised the right of Indonesian domestic workers to one day off work per week as well as the right to retain their passports rather than hand them over to their employer. Legal rights for Indonesian workers and their Malaysian employers were also agreed upon. During the same period, plans were reportedly afoot to develop the so-called 'Indonesian Social Security Programme', which would formalise discussions on ensuring that Indonesian workers are met at the airport by their employer, have automatic access to legal assistance, are registered on an online system, have access to counselling and a 24-hour call centre, and have automatic insurance (Bangun 2010).

Of equal importance is ASEAN's step toward the enactment of a regional agreement, through the Cebu Declaration on the Protection and Promotion of the Rights of Migrant Workers, adopted in January 2007. It called for ASEAN members to develop a common standard or charter on migrant workers' rights that would apply to all ASEAN members. The goal was to promote the welfare of migrant workers and to improve their access to avenues of justice (Arifianto 2009). However, the Cebu Declaration contains a number of limitations. Typical of statements issued by ASEAN, the declaration was short on specifics and contained some escape clauses that gave room for member countries to interpret it in their own way (Arifianto 2009: 626). Furthermore, it is phrased in terms of the sending-country's obligations (as well as ASEAN commitments) rather than in terms of the individual rights of migrant workers. These obligations are, moreover, subject to the prevailing laws, regulations and policies of the respective sending and receiving states. Nevertheless, the commitment of ASEAN to develop a legally binding charter on the protection and promotion of the 
rights of migrant workers as well as the adoption of the Cebu Declaration are themselves significant developments (Cholewinski 2010: 288). It was, after all, the first time ASEAN had developed a common framework for the promotion of migrant workers throughout Southeast Asia. Of course, there is a long road ahead before ASEAN members can fully agree to the terms of such an agreement, and tensions between labour-sending countries, such as Indonesia, and labour-receiving countries, such as Malaysia, will no doubt persist.

Ultimately, Indonesia's transition to democracy, accompanied by an increasingly international outlook, appears to be resulting in a more concerted effort to deal with regional human security issues such as the treatment of migrant labour. The deepening of democracy in Indonesia has also ensured that the Indonesian government is more prepared to incorporate Track II and Track III input from NGOs into its regional decision-making. This is a significant development, as some grassroots migrant-labour NGOs have worked hard to become bodies that can speak directly for migrant workers. As described by Ford and Susilo:

NGO workers have begun to use the legal system to put pressure on the government to better meet the needs of the country's migrant workers. For example, in 2002 they organised a class action lawsuit against the Indonesian government following the deportation of almost 140,000 undocumented migrant workers from the Malaysian state of Sabah. Up to 70 deported migrant workers died in the border town of Nunukan and thousands more suffered from serious illnesses, including dysentery and malaria because of the simple fact that the Indonesian government was unprepared for their arrival. The court recognised the government's negligence in the first instance before the decision was overturned on appeal. Even though it failed, this initiative set an important precedent for Indonesian public law, with civilians beginning to use the legal system to sue the state for deliberate failures to provide essential public services. (2010)

Subsequently, the Indonesian government has actively incorporated the opinions and input of NGOs and other non-governmental actors in the regional decision-making process (Oratmangun 2009). Indeed, committed as it is to the key principles of democracy, the government has little choice. Moreover, as part of a newly democratic nation, Indonesian citizens are becoming increasingly well-informed about Indonesia's regional engagement. Indonesian citizens and NGOs, frustrated by being continuously locked out 
of the elite 'talk-fests' of ASEAN's summit diplomacy, are also increasingly articulating their desire to participate in intra-regional political diplomacy (Suryodiningrat 2004; Sukma 2008).

In addition to Indonesia's apparent commitment to democratic public deliberation processes, in signing the Cebu Declaration the Indonesian government sent an emphatic signal of its readiness to 'regionalise' the labour migration issue. Academics and NGO lobbyists have consistently warned the government that the transnational migrant labour issue is now a regional issue, as it is unnecessarily straining diplomatic relations between labour-sending and labour-receiving nations in the region, as we have seen in the last decade between Indonesia and Malaysia (Arifianto 2009). The best way to avoid potential conflict between labour-sending and labour-receiving countries, they propose, is to regionalise the issue, so that a common standard can be applied to the recruitment of migrant workers and the protection of their rights from abusive employers and premature deportation. It is also intrinsically important that Indonesia's labour-migration problems with Malaysia are generally regarded as a regional human security issue rather than a national security issue, as in Malaysia, because a human security framework has the potential to raise the issue above and beyond the domestic sphere and the neo-nationalistic vagaries of competing political voices. As with the recent transformation of Indonesia's foreign policy orientation, however, this change in focus does not necessarily contribute to an enhancement of regional integration. Despite the previously discussed benefits of Indonesia's more outwardlooking foreign policy orientation, other countries in the region continue to raise their eyebrows. On the one hand, nearby countries such as Singapore and Malaysia remain stoically bemused by Indonesia's at-times-painful political transformation, even though the hard truth is that Indonesia is now Southeast Asia's only truly democratic nation. On the other hand, Indonesia's neighbours are fearful of an ASEAN without Indonesia's full participation or engagement, as they have much to lose from a devalued ASEAN.

Regional circumspection notwithstanding, in the post-New Order period, Indonesia has concentrically expanded its foreign policy outlook beyond its immediate region and has kept a close eye on maintaining the approval of the United States. Therefore, efforts to develop a regional solution to the migrant labour issue through democratic public deliberation, in both the domestic and the regional context, cannot be examined without full consideration of the transformation of Indonesia's domestic political situation, which clearly has regional reverberations. 


\section{Conclusion}

In Southeast Asia, the links between democracy and regional integration, and vice versa, are not immediately discernible. Democratisation in the founding countries of ASEAN, such as Indonesia, the Philippines, Thailand and, less markedly, Malaysia and Singapore, has not triggered a deepening of regional integration. Political diversity in the Southeast Asian region, especially differences in the degree of democratisation, is a key reason why this has not occurred. As a consequence, important regional issues, such as very large intra-regional migrant-labour flows, epitomised by the large numbers of Indonesian migrant workers in Malaysia, have failed to find a regional solution. Yet Indonesia's successful transition to democracy has led to stronger efforts to seek a regional solution to the complex issues of human security in the region. The human rights of Indonesian migrant workers are now an issue that the Indonesian government is more determined to deal with both domestically and regionally as it becomes more democratic and broadens its regional foreign policy orientation.

Democratic Indonesia's enlightened approach to human rights has been stymied by its neighbours' intransigence. Malaysia, the principal receiving country of Indonesian migrant workers, continues to regard the migrant worker issue as a national security issue rather than a regional human security issue, which is more likely be solved through regional decision-making. Moreover, Malaysia and other key ASEAN members, such as Singapore, regard Indonesia's calls for political reform in ASEAN and other examples of regional muscle-flexing with apprehension, as changes to the regional status quo could quite easily have a negative impact on the integrity of ASEAN as a whole and the domestic stability of each ASEAN member.

Indonesia's push for political reform in the region, coupled with its increasingly pro-active foreign policy orientation, has not triggered greater regional integration in Southeast Asia. In relation to this, there is an old joke that meetings are held to ensure that nothing changes. True to that adage, Indonesia's key regional partners, including Malaysia and Singapore, are becoming increasingly determined to ensure that any change in the region - if it occurs at all - follows the so-called 'ASEAN way' and all it stands for, including consensus decision-making and non-interference in the domestic politics of member countries. Consequently, Acharya's prediction that regional cooperation in Southeast Asia will not necessarily be strengthened by the emergence of democracy in the region (2003) fits in nicely with the arguments made in this chapter. Such strengthening of regional cooperation will be hindered, first of all, by the differing degrees 
of democratisation in Southeast Asia and, secondly, by Indonesia's desire to overcome ASEAN's many limitations through a rather unsubtle process of democratic projection, which arises, no doubt, from its own domestic political change. While Indonesia's vibrant democratic progress has encouraged the government to push the envelope in the region, the soft-authoritarian democracies of Malaysia and Singapore, not to mention the democratic backsliders of Thailand and the Philippines, have ensured that democracy has not yet become the golden key that opens all locks. As Missbach argues in the next chapter of this volume, even in Indonesia, democracy does not guarantee the human rights of transit migrants, who are, on the whole, treated with disdain. 



\title{
$7 \quad$ Transiting asylum seekers in Indonesia
}

\author{
Between human rights protection and criminalisation
}

Antje Missbach

\section{Introduction: Death in detention}

Taqi Nekoyee, a young man from Afghanistan, died on 28 February 2012 in the Pontianak immigration detention centre (UNHCR 2012f). The autopsy on his body revealed massive wounds resulting from severe beatings, cigarette burns and torture, which he had suffered during the previous night. Taqi had arrived in Indonesia in mid-2011 and applied to the United Nations High Commissioner for Refugees (UNHCR) for refugee status, hoping to be resettled in a safe third country. He had been in custody in the Pontianak immigration detention centre since early November 2011 for breaching travel restrictions imposed on asylum seekers (Amnesty International 2012). Two days before his death, Taqi escaped from the detention centre together with five Afghani friends. The following day, the police re-captured three of them, including Taqi (Warga Afganistan tewas 2012). The initial report filed upon their return to the immigration detention centre stated that the re-arrested men were in good health. In the night following the arrest, Taqi was beaten to death by a group of ten guards in the detention centre (Haryanto 2012; Komnas HAM Kalbar kunjungi imigran korban penganiayaan 2012).

Immediately after Taqi's death became known, the local authorities started their investigations. Ten guards who were on shift that night were taken into police custody. The charges laid by the prosecutors carried a sentence of imprisonment for only one year, although under the Indonesian Criminal Code paragraph 351, prison sentences of between five and seven years are appropriate for maltreatment resulting in death. Due to the media attention the incident received, representatives from the national directorate-general of immigration and other ministries paid visits to Pontianak. An Indonesian government official commented:

What we wish to convey is that for the government of Indonesia, it is not relevant whether the victims are asylum seekers or are from Afghanistan - that does not matter, because in the eyes of the Indonesian law a crime 
has been committed. The victim happened to be a foreigner, but all the perpetrators will be sentenced by law. ${ }^{1}$

Although Taqi's death was the first fatality, or at least the first that became known to the public, Amnesty International claims in a recent report that the 'use of torture and other ill-treatment by law enforcement officials in detention is still widespread in Indonesia' (2012). In my interviews of former detainees, they have accused their guards and Indonesian police personnel of discrimination, mistreatment, violence, extortion and theft. Conversely, police officers and detention guards also complained about violence exercised by transit migrants against them, especially during interceptions and attempted breakouts. ${ }^{2}$

Besides the UNHCR and Amnesty International, a number of local institutions, first and foremost the National Human Rights Commission KOMNAS HAM, also expressed their concern over the treatment of detained asylum seekers and over the death of Taqi Nekoyee in particular (Haryanto 2012). Two weeks before the incident in Pontianak, KOMNAS HAM Chairman Ifdhal Kasim issued a press statement saying that the government is considered not to have a comprehensive national policy on the handling of refugees and asylum seekers. Policies and the handling are still unintegrated, sporadic and insufficient from a human rights perspective' (Santoso \& Suprihadi 2012). Of particular concern to KOMNAS HAM is that the cooperation between the institutions involved in handling transit migrants, such as the police, the army, the department of foreign affairs, the directorate-general of immigration and the UNHCR, is not well-defined. Kasim also criticised conditions in Rudenim as 'prison-like' (Santoso \& Suprihadi 2012), causing many detainees to experience psychological stress, consider suicide or attempt to escape.

In general, the relevant Indonesian authorities reject reports about the alleged inappropriate behaviour of guards at the local immigration detention centres. When asked about the violent treatment of detainees, the standard reply is that the general conditions in the detention centres are very humane and much better compared to Indonesian prisons. Responsible authorities portray guards and police officers who have used physical violence against transit migrants as individual exceptions (oknum), not the rule. Rather

1 Interview with Masni Eriza, deputy director of humanitarian affairs, ministry of foreign affairs, 4 April 2012, Jakarta.

2 Interview with intelligence officers Osep Guneriadi and Sumarioto, 6 February 2012, Pelabuhan Ratu. 
than coming to the defence of the perpetrators or showing understanding of why respective guards might have misbehaved, Indonesian officials instead point out the training received by police and immigration officers in recent years aimed at sensitising them to human rights. Only in very few cases did I encounter a complete lack of sympathy for asylum seekers among immigration officials or police officers. Given that Indonesia is still a developing country and has only very recently embarked on a transition to a democracy, all efforts - or any lack thereof - need to be put into perspective. Even though this chapter argues that the predominant concern of the Indonesian government and its governing bodies is the criminalisation of transit migrants as 'illegals' rather than the protection of their human rights, it would be wrong to ignore all the positive developments made so far with regard to safeguarding the human rights of non-citizens.

This chapter aims to provide insights into the realities of the daily lives of transit migrants, including both those who are detained in immigration detention centres and those who are allowed to live within local Indonesian communities. Acknowledging the Indonesian state's increasing concern about upholding the human rights of non-citizens residing in its territory, this chapter not only shows recent attempts at improvement but also points out remaining gaps. Whereas the media and activists often depict irregular migrants as victims because they lack rights, a scholarly perspective should apportion greater agency to migrants. By depicting transit migrants as not solely 'victims' but rather as active agents who make their own decisions and negotiate their way through difficult political, social and legal terrain, I hope to portray transit migrants as rationally acting human beings who, although they face many problems, make choices to counter these. For this chapter, I rely on open sources as well as on input from both transit migrants and state authorities. ${ }^{3}$ Perspectives forwarded by transit migrants and local authorities were often contradictory; in most cases, the truth may be situated somewhere in between.

After providing some background information about transit migration in and out of Indonesia, I will discuss the role of the Indonesian state as well as a number of legal ambiguities that are responsible for the inconsistencies in the handling of transit migrants in Indonesia. As the Indonesian state is not

3 My scholarly interest in transit migration in Indonesia dates back to late 2009. At first, I followed the developments from afar; then, in March and June 2010 and in November 2011, I had personal encounters with transit migrants in Indonesia. For ten months in 2012, I conducted fieldwork in Indonesia. Although I care about accuracy of reference, I feel a heavy obligation to protect some of the people who were my sources and do not, therefore, always give the full names of informants or the dates and places of interviews. 
capable of handling the recent increase of transit migrants alone, the roles of the international key players in the field of irregular migration - the UNHCR and the International Organization for Migration (IOM) - require special attention. I then give some insights into the daily lives of transit migrants. The chapter ends with a preliminary evaluation of the Indonesian balancing act between the criminalisation of transit migrants and the protection of their human rights, which is largely in response to the Australian government's securitised efforts to fend off unwanted immigrants.

\section{Transit migration in and out of Indonesia}

Over the last decade, Indonesia has become an important transit country for asylum seekers, recognised refugees and stateless people, as well as for those who do not qualify for any of these categories and can therefore be referred to simply as migrants. I prefer to use the generic term 'transit migrant' even though the term is controversial. Whereas categories of migration are generally labelled according to the circumstances of departure (voluntary or forced), the motivations for departure (economic or rescue), or the outcome of the migration process (resettled refugee, temporary migrant worker), transit migration does not denote a type of migration but rather certain phases in the whole migration process. In fact, transit migration can involve 'various motivations, legal statuses and living and employment conditions' (Collyer 2010: 275) and different durations of stay and places to live. Transit migrants are caught between types of migration as their status may change continually, especially if they live in transit over a longer period of time or in different places.

Generally speaking, transit migrants in Indonesia do not intend to stay for the long term. Rather, they are looking for opportunities to resettle in safe, third countries, first and foremost Australia. Resettlement ideally takes place through the UNHCR and the IOM; however, some transit migrants impatient with the slow procedures may opt for 'self-organised' resettlement with the help of people smugglers (Missbach \& Sinanu 2011). The latter option is highly dangerous and not necessarily a fast track, as many transit migrants who arrive in Australia are still subject to mandatory detention, at least during the health and security checks.

Since 2008, there has been a distinct rise in the number of new transit migrants in Indonesia. The numbers of people of concern to the UNHCR have increased from 385 in 2008 to 3,230 in $2009,3,905$ in $2010,4,293$ in 2011 and 7,945 in late 2012 (UNHCR 2011b, 2013a). The absolute majority 
of registered asylum seekers and refugees originate from Afghanistan, followed by Pakistan, Iran, Iraq, Myanmar, Somalia and Sri Lanka. Smaller numbers hail from Sudan and South Sudan, Palestine, China and Syria. In March 2013, the UNHCR in Jakarta administered 9,656 cases, which consisted of 7,720 asylum seekers and 1,936 recognised refugees $(8,071$ male and 1,585 female). Most are aged between 18 and 60 years, but the number of unaccompanied minors has been consistently on the rise over the last few years.

What needs to be kept in mind when considering these still relatively low official numbers of transit migrants is that only a certain fraction of transit migrants register with the relevant institutions such as the UNHCR. The real number of transit migrants in Indonesia is most likely to be much higher for a number of reasons. Some transit migrants do not wish to register as asylum seekers with the UNHCR as they do not see much benefit in doing so or they do not know how. Others, such as those who are arrested soon after their arrival, might not have had a chance to register yet. There are also inconsistencies in data shared between the UNHCR and other involved bodies, such as the IOM and the Indonesian secretariat-general of immigration. Every institution has its own collection of statistics. Numbers are deemed incomplete as, for example, the Indonesian secretariat-general of immigration, whose statistics date back only to 2010, only counts transit migrants who are detained. It is probably safe to estimate that the real numbers are at least twice as high as the various official statistics claim. The newly introduced biometric data management system might provide more reliable figures in the future.

Migrants choose Australia as the desired resettlement country and Indonesia as the transit country over other potential routes and destination countries, such as Turkey and Greece (the main eastern gateways into EU territory), for a number of pragmatic reasons. Smuggling fares, for example from Pakistan via Indonesia to Australia, are generally cheaper than those for the journey to Germany, for example, via Iran, Turkey and Greece. Reaching Indonesia is believed to be less dangerous than travelling through transit countries such as Turkey. Some of my informants favoured Indonesia, as they had heard stories of cruelty from people who had been to Turkey and/or failed to enter the EU. Whether entirely true or not, the narratives were about armed robbers who either kidnapped transit migrants and held them to ransom in the mountains until their families back in their homeland sent money or tortured their victims. ${ }^{4}$ To a lesser degree, even 
the current economic recession in Europe served as an explanation for not trying to reach Europe.

With Australia as its close neighbour, Indonesia appears to many migrants to be a practical choice as a transit country. In the last ten years, Indonesia has enjoyed relative political stability. Indonesia's lengthy maritime borders are porous, making the country rather easily accessible. Given the low living costs and the toleration hitherto of irregular migrants by Indonesian authorities, Indonesia seems a good starting point for transit migrants. The various services provided by the UNHCR and the IOM, as will be explained later, also help to cushion migrants against some of the hardships of transit. Last but not least, since the majority of transit migrants hail from Muslim countries, Indonesia, which has the world's largest population of Muslims, holds some attraction.

I observed that there was little sense of Muslim solidarity with the transiting migrants, and that what little there was had little influence when it came to renting houses and using services, as local Indonesians would generally demand inflated prices for both (see also Krismantari 2010). Nevertheless, non-Muslim transit migrants from Vietnam or Sri Lanka faced even greater problems when it came to finding accommodation and transportation. ${ }^{5}$

There are a number of ways in which transit migrants come to Indonesia. Generally, transit migrants who are unable to acquire proper travel documents in their homeland, either because there is no bureaucratic infrastructure or because it is very slow one, use fake passports and visas provided to them by people smugglers. Quetta (Pakistan), for example, has earned a reputation as a provider of such services. While border control in Indonesia has been rather lenient over the last decade, new and more sophisticated passport controls are now being installed to detect fake documents. A small percentage of people (e.g. Iranian and Sudanese) arrive directly in Indonesia by plane with valid documents, such as short-term visitor visas or tourist visas issued on their arrival. Their entry is regular, and it is only when they decide to overstay or leave Indonesia outside an official port of embarkation that their presence becomes irregular. In the meantime, they can register as asylum seekers and/or try to organise the next leg of their trip to Australia. Visas are only available on arrival in Indonesia to people from certain countries, not including Afghanistan and Iraq. Most transit migrants from Afghanistan and Iraq go first to Malaysia or Thailand before entering

5 Interview with Arya Perdana, Anti-People Smuggling Task Force, Criminal Investigation Bureau of the Police, 10 February 2012, Jakarta. 
Indonesia. Unlike Indonesia, Malaysia offers visas on arrival to more than 60 countries. Transit migrants cross from Malaysia to Indonesia by boat or by plane. One heavily frequented route is from Quetta straight to Kuala Lumpur or with a short stopover in Bangkok, then from Johor in Malaysia by boat to the Indonesian island of Batam and subsequently by plane to Jakarta. Short-term shelter in Malaysia and the passage from Malaysia to Indonesia costs between USD 500 and USD 1,00o. In some cases, transit migrants take the same boats as returning Indonesian overseas workers without valid documents. Before taking a boat to Indonesia, transit migrants normally get rid of their real or fake identity documents, so that they cannot be immediately deported if they are intercepted. Although the Johor-Batam route is one of the shortest, there are plenty of irregular harbours on Malaysia's west coast and Sumatra's east coast that serve as entry points. Those who do not want to risk being caught at an airport, where police and immigration officials are likely to conduct stricter surveillance, might also travel to Jakarta from Sumatra overland by bus (and ferry). Because the UNHCR headquarters are in Jakarta, at least a short stopover is required for those who intend to register as asylum seekers.

Even though asylum seekers can register with the UNHCR in Kuala Lumpur, many prefer to apply in Jakarta, as the UNHCR in Malaysia has an overload of cases. At the end of August 2013, it was handling some 108,336 refugees and asylum seekers and an estimated 49,00o unregistered asylum seekers (UNHCR 2013b). Some people who cross over to Indonesia clandestinely already hold refugee status from the UNHCR in Malaysia, but they have become tired of waiting for resettlement in Malaysia and so move on to Indonesia. The secondary movement does not accelerate their resettlement process at all, as the UNHCR in Indonesia has to verify their status. If possible, transit migrants avoid staying in Malaysia for the long term, not only because of the higher living costs, but more importantly because, unlike Indonesia, Malaysia is less tolerant towards 'illegal' migrants (pendatang haram). Offences against immigration laws in Malaysia carry severe punishments, including physical punishments such as caning. Also, Malaysia has in the past deported asylum seekers who were registered with the UNHCR (Human Rights Watch 2009).

While a number of transit migrants are caught when entering Indonesia, the majority tend to be intercepted when trying to leave Indonesia. ${ }^{6}$ While in the early 2000s, West Timor and other islands in Eastern Indonesia were 
the most frequented sites for departure due to their proximity to Australia's Ashmore Reef, stricter border controls were put in place, which meant that people smugglers had to open additional routes. In 2011 and 2012, most interceptions took place in West Java and Banten, as these sites are closer to Christmas Island, one of the main entry points into Australian territory. Given that these southern Indonesian coastlines are currently under stricter surveillance than before, harbours located further north, such as Baubau and Makassar, and harbours along Java's north coast, have become alternative departure points.

\section{The Indonesian state and the (lack of) protection of asylum seekers and refugees}

For a long time Indonesia has paid little attention to irregular migration into and within its national territory, making it a relatively easily accessible transit country in the region. Nonetheless, Indonesia is not very keen to receive asylum seekers and refugees. It is not a signatory to the 1951 United Nations Convention Relating to the Status of Refugees and the 1967 Protocol (hereafter referred to as the Refugee Convention) and does not, therefore, offer refuge to asylum seekers, but it tolerates the presence of asylum seekers and refugees as long as they remain under the care of the UNHCR. Indonesia has indicated its intention to sign the Refugee Convention, even listing it in its 2005-2009 National Legislation Program (Prolegnas), but nothing has happened so far. Even if Indonesia were to ratify the Refugee Convention eventually, it would not be immediately equipped with a domestic framework to process asylum seekers effectively and fairly (Lindsey 2002).

Government officials usually give as the main reason for abstaining from signing the Refugee Convention the financial responsibilities that are attached to becoming a signatory. In spite of this, the Indonesian state should guarantee asylum seekers and refugees a minimum level of protection because Indonesia is party to other relevant international conventions, such as the Convention against Torture and Other Cruel, Inhuman or Degrading Treatment or Punishment (CAT) and the International Convention on Civil and Political Rights (ICCPR). As a signatory to the Convention on the Rights of the Child, Indonesia carries special responsibility for the protection of under-aged asylum seekers and refugees.

7 Interview with Dyah Kusumawardani, directorate of human rights and humanitarian affairs, ministry of foreign affairs, 26 January 2011, Jakarta. 
Because Indonesia lacks the domestic mechanisms for processing the applications of asylum seekers, it relies solely on the UNHCR to determine who is a genuine refugee and who is not (Department of Justice and Human Rights 2002). Nevertheless, there are at least four domestic laws with provisions relating to asylum in and non-extradition from Indonesia. First, the second amendment to the 1945 National Constitution stipulates that '... everyone has the right for political asylum in other countries'. Second, Law 1/1979 on Extradition (Chapter 2, paragraph 14) states:

Requests for extradition will be rejected if the relevant authorities have well-founded suspicions that the person who is requested for extradition will be prosecuted, convicted or become subject to other punitive actions because of this person's religion, political beliefs, nationality, ethnic or minority status.

Third, Law 39/1999 on Human Rights stipulates in Article 28(1) that 'Everyone has the right to seek and receive political asylum from another country'; Article 7(1) and (2) of the Human Rights Act provides for the due process of law to be accorded to all those in Indonesia who have suffered from human rights abuses and reiterate that international law instruments ratified by Indonesia are legally binding (Government of Indonesia 1999b). Article 7 effectively enforces the legal obligation against refoulement, ${ }^{8}$ as set out in Article 3(1) of the Convention Against Torture and Other Cruel, Inhuman or Degrading Treatment or Punishment, to which Indonesia is a party. Fourth, and maybe most significantly, Law 37/1999 on Foreign Relations contains three paragraphs that refer to the right to apply for asylum in Indonesia, such as Chapter VI (paragraphs 25-27) entitled On granting asylum and the issue of refugees. Paragraphs 25(1-2) and 26 of this law state that:

Authority to grant asylum to foreigners in the hands of the President with regard to the opinion of the Minister. This authority referred to in paragraph (1) will be regulated by a Presidential Decree. Asylum to aliens is granted in accordance with national legislation and with due regard to the laws, customs, and international practice. (Government of Indonesia 1999a)

8 Refoulement means the forced return of asylum seekers to countries in which their lives may be threatened or their freedom limited as a result of persecution. Non-refoulement is considered customary law even for countries that are not signatories to the Refugee Convention. 
However, these provisions have not been properly implemented, and there is simply no legislation that specifies asylum procedures. The Presidential Decree mentioned in Law 37/1999 has never been issued. All there is so far is the Regulation of the Director-General IMI-1489.UM.08.05 on the Handling of Illegal Immigrants from 2010, which states that irregular migrants are subject to Indonesian immigration laws but that they will be tolerated for the time being as long as they register with the UNHCR. Indonesia's concern for asylum seekers and refugee protection is, therefore, limited to nonrefoulement. Even though the status of asylum seekers and refugees might remain unclear from the legal perspective, Indonesian government bodies are concerned about 'the problem of refugees and asylum seekers first and foremost in regard to the protection of victims of people smuggling'. ${ }^{9}$ Currently several ministries are involved in drafting a standard procedure for the handling of asylum seekers in Indonesia.

In lieu of a legal framework for asylum seekers, Indonesia relies primarily on its laws regulating immigration, especially the Law on Immigration (Government of Indonesia 2011). This means that when transit migrants enter Indonesia irregularly, even though they might be looking for asylum or have been acknowledged as refugees elsewhere, they will be subject to the law on immigration, as the state sees them primarily as 'illegal immigrants'. ${ }^{10}$ Although many human rights organisations argue that the detention of irregular immigrants is arbitrary, Indonesian state authorities object to the comparison of immigration detention centres with prisons. From the Indonesian government's perspective, the temporary placement of transit migrants in immigration detention centres is not punishment but rather as a 'means of protection'. In the words of Masni Eriza, deputy director of humanitarian affairs at the ministry of foreign affairs: ${ }^{11}$

In principle and from the government point of view, putting them into a detention centre is a form of protection. Only there can we make sure that they are safe and sound. By giving access to the international organisations whose job is to take care of them, it is also ensured that they have access to health care and to some extent also have access to education for their children. Outside of detention centres, we cannot guarantee that.

9 Interview with Dyah Kusumawardani, directorate of human rights and humanitarian affairs, ministry of foreign affairs, 26 January 2011, Jakarta.

10 Interview with Masni Eriza, deputy director of humanitarian affairs at the ministry of foreign affairs, 4 April 2012, Jakarta.

11 Interview, 4 April 2012, Jakarta. 
Although the placement in detention centres is supposed to be temporary, according to the Immigration Law (6/2011) irregular migrants can be detained for a maximum period of ten years. Victims of people smuggling are, according to the Law, exempted from detention. But in reality, they too end up in detention. In the course of implementing the National Action Plan for Human Rights in Indonesia (Rencana Aksi Nasional Hak Asasi Manusia Indonesia, RANHAM), Indonesia has become more aware of its obligation to uphold the human rights of the inmates of immigration detention centres. ${ }^{12}$ Unfortunately, as the following section on the realities of daily life for detained transit migrants will show, more needs to be done. Legal integration into Indonesia and naturalisation are not options because the Law on Indonesian Citizenship (Government of Indonesia 2006) does not permit refugees to apply for citizenship (Taylor \& Rafferty-Brown 2010a). ${ }^{13}$ Recognised refugees can apply for resettlement to a safe, third country, but they can wait many years, as it requires a number of interviews, security and health checks. Many may never be resettled, as the UNHCR does not guarantee the right of resettlement to genuine refugees. Whether somebody is resettled depends on his or her specific case and even, maybe to a greater extent, on the annual resettlement quotas of the countries receiving refugees. Some recognised refugees have been in Indonesia for ten years or more.

Asylum seekers whose claims have been rejected twice are supposed to leave Indonesia. They can do so by accepting the repatriation package provided by the IOM and returning to their country of origin. To accept this option, they need valid travel documents, which many transit migrants no longer possess. Indonesia does deport rejected asylum seekers but, because of their high cost, only 20-30 deportations are carried out each year. ${ }^{14} \mathrm{Be}-$ tween January 2010 and December 2012, 867 refugees from Indonesia have been resettled in third countries, whereas 1,181 asylum seekers agreed to be voluntarily repatriated (IOM 2012 and 2013). While voluntary repatriation is

12 For example, in 2011, the ministry of justice and human rights published a small guidebook on human rights for officers and guards in immigration detention centres (Ministry of Justice and Human Rights 2011).

13 As some transit migrants have lived in local communities for many years, some have married local women and established families. These marriages (kawin sirih) are performed according to Islamic law but are not registered at a civil registry, so transit migrants cannot legalise their residency status through marriage to an Indonesian. The children of such couples mostly take the citizenship of their mother, that is, Indonesian. Legally, these children are in a difficult position, as they cannot, for example, inherit their fathers' wealth. If the father is resettled, the family has to prove its de facto status for the entire family to be resettled.

14 Interview with Hongky Juanda, head of section on irregular migrants and the protection of victims of transnational crime, directorate general of immigration, 5 March 2012, Jakarta. 
the most desirable solution in the eyes of the Indonesian government, it is out of the question for those whose homelands face ongoing war, and many transit migrants linger on in Indonesia. In theory, there is no limit on the length of temporary stay for long-term stayers in Indonesia if, for example, rejected asylum seekers refuse to return to their countries of origin and if countries of origin will not accept the return of former citizens by issuing new travel documents. Some transit migrants, if they still have access to money from family and friends, chose to risk their lives on dangerous boat trips to Australia. For those who do not qualify as refugees and have sold all their assets, life is most difficult, as they are literally trapped in transit.

Meanwhile a number of Indonesian state officials have started viewing transit migrants as a potential threat to national security and political, economic and social stability. In addition, they worry about public health and Indonesia's international reputation, especially in regard to its human rights record. From such a perspective, Asep Kurnia (2011, vii), a graduate of the National Resilience Institute (LEMHANAS), speaks probably on behalf of many when writing that:

The issue of illegal immigrants is a very sensitive and multidimensional issue that can easily be politicised. Within Indonesia, the presence of illegal immigrants has started to upset the local society, especially those people in the vicinity of the shelters and immigration detention centres. The issue of illegal immigrants also brought negative impacts for the relations between Indonesia and other countries as well as for the image of Indonesia in the international world.

Despite such fears expressed by individual observers and law enforcers, most political decision-makers in Indonesia do not consider transiting asylum seekers and refugees as a political priority yet. Thus issues such as human rights protection for those who are travelling through Indonesia on their way to Australia are considered insignificant politically. Given that asylum seekers are to a certain extent cushioned against hardship by international migration and refugee organisations such as the UNHCR and the IOM, the decision-makers do not see much need for action or a change in the status quo.

\section{The roles of UNHCR and IOM in Indonesia}

As already stated, Indonesia tolerates asylum seekers and refugees as long as they are under the care of either the UNHCR or the IOM. The two 
organisations play very important roles in handling transit migrants, as the Indonesian state passes its responsibilities on to them. Both organisations started operating in Indonesia in 1979, when Indonesia became a place of temporary refuge to Vietnamese asylum seekers. The UNHCR is mainly concerned with protecting asylum seekers (meaning preventing refoulement) and determining their status. The refugee status determination procedure requires each asylum seeker to be interviewed by a UNHCR official in the presence of a trusted interpreter. The claim for protection is assessed and, once a decision is reached, the asylum seeker is provided with a reasoned decision on whether refugee status is granted or not. If rejected, each asylum seeker can appeal once against the negative decision. Together with its partner organisations, the UNHCR also takes care of the psychological and social needs of persons of concern, be it through counselling, home visits or facilitating self-help group activities, such as sewing or handicrafts.

In 2011, the UNHCR in Indonesia operated on a budget of USD 7,677,369 (UNHCRa). As the staff of the UNHCR in Indonesia is rather limited in number, the status determination process can take many months. There is a shortage of translators and interpreters, especially of Persian interpreters, who often have to be flown in from Australia. Although applying for protection under the UNHCR is very time-consuming, it is worthwhile because a letter from the UNHCR stating that the person is an asylum seeker or a recognised refugee awaiting resettlement guarantees at least the minimal protection of non-refoulement. Attestation letters for asylum seekers have to be renewed every two months for monitoring and statistics-gathering purposes, whereas attestation letters for recognised refugees are renewed only once a year. People without legal documents and without UNHCR letters who are caught by the police or migration authorities are arrested and placed in immigration detention centres. Usually the police then do an initial investigation and report their cases to the IOM.

Despite the fact that Indonesia is not yet a member of the IOM, the organisation is involved in regulating transit migrants in Indonesia in many ways. It assists the Indonesian and Australian governments in controlling the movements of irregular migrants across the archipelago. Under the tripartite Regional Cooperation Model agreement, signed in 2001, the IOM arranges the logistics of the resettlement to third countries. Should asylum seekers opt for repatriation to their home countries, the IOM takes care of the necessary procedures. Although voluntary repatriation might not always be particularly 'voluntary', especially for those who have been rejected for refugee status, those who accept it are 'rewarded' with a lump sum upon arrival in their home country, provided by the IOM. 
Since 2007, the IOM has been implementing a project entitled Reinforcing Management of Irregular Migration. This project includes the detection and monitoring of patterns of irregular migration flows in Indonesia (IOM 2010c). In particular, the project aims to raise awareness about irregular migration and the pitfalls of people smuggling for Indonesians involved in the trade, especially among local fishing communities (Alford 2012). Moreover, the IOM has also been training Indonesian counterparts at the national and the local level. Over the last years, it has trained the staff of immigration detention centres and local police in how to uphold the human rights of arrested and detained transit migrants (IOM 2011b). For example, the IOM has worked with the ministry of justice and human rights to produce a handbook for detention centre staff on the rights of detained irregular migrants which gives guidance on the appropriate handling of detainees in everyday and emergency situations. The IOM has also financed and contributed to a number of reports about irregular migration and people smuggling in Indonesia.

Besides capacity-building, IOM carries the lion's share of housing the detained transit migrants. The IOM has not only paid for the renovation of existing detention centres and the construction of new ones, for example in Tanjung Pinang (Bintan Island) and Kalideres (Jakarta), but it has also covered all costs for food, clothing and personal needs provided to the detainees. Whereas the Indonesian state budget covers the costs of running the centres and their staff, ${ }^{15}$ the IOM pays for health care and language classes for the detainees and any costs relating to their relocation to other detention centres or into local communities (IOM 2010a). Because of overcrowding in immigration detention centres, a number of refugees and asylum seekers, especially those with families, have been accommodated in community housing schemes within local communities, which may be local hotels rented for the long term or newly-built housing complexes. In addition to this, the IOM provides every person under its auspices with a monthly allowance.

Compared with other similar missions worldwide, the IOM in Indonesia is well funded. A significant proportion of its funding is from Australian partners, notably the Australian department of immigration and citizenship and the Australian federal police, with other funds for managing irregular immigration in Indonesia coming from other sources, including the European Commission and through the Dutch and Japanese embassies.

15 The Indonesian ministry for justice and human rights spends about Rp 46 billion (AUD 5 million) per year on data collection relating to detainees and on their supervision in the detention centres, and another Rp 30 billion (AUD 3 million) for overheads (Kurnia 2011). 
According to its 2009 annual report, the IOM received USD 21,407,194 from the Australian department of immigration and citizenship, USD 668,869 from the Australian customs and border protection service and USD 183,887 from the Australian federal police (IOM 2010a, 104). In 2010, the Australian government contributed USD 11,270,888 towards the care and voluntary return of irregular migrants from Indonesia and an additional USD 3,059,441 for the immigration quarantine support project. Altogether, the IOM's total expenditure for 2010 was USD 26,634,503 (IOM 2011c). The IOM's strong financial position has allowed the organisation to become a very influential player in controlling irregular migration in Indonesia.

\section{Everyday realities of transit migrants in Indonesia}

Once they have been intercepted, transit migrants are either housed in immigration detention centres or live in local communities, where they either benefit from the services of the IOM or the UNHCR and its local partner organisations, or they survive entirely on their own. The following paragraphs shed some light on their living conditions while in transit in Indonesia.

In Indonesia, there are 13 immigration detention centres (in Tanjung Pinang, Surabaya, Semarang, Pontianak, Pekanbaru, Medan, Manado, Makassar, Kupang, Jayapura, Jakarta, Denpasar and Balikpapan). From media reports, activists and scholars who have visited such centres, it is known that the conditions are generally poor (Taylor 2009). Most are overcrowded. For example, the Kupang detention centre was built to hold 60 people but had to shelter up to 240 people at times in $2010 .{ }^{16}$ According to former detainees, hygiene standards are poor, and food and nutrition are often substandard. Detention centres allocate Rp 15,000 (USD 1.50) per person per day for food. As this amount is often insufficient, especially in the outer islands where food is generally more expensive, the IOM provides another Rp 45,00o per day per person for food. The total of these two amounts is more than five times what inmates in Indonesian prisons receive. Nevertheless, because of embezzlement and other forms of corruption, not all the money allocated for detainees is spent on them. In reaction, there are hunger strikes in protest at the low quality of food, such as that in Kupang in February 2012. ${ }^{17}$

16 Interview with Budi Prayitno, chief of the registration and reporting section, Kupang detention centre, 16 November 2011, Kupang.

17 Interviews with two detainees in Kupang, April 2012. The hunger strike was confirmed by the heads of the detention centre in Kupang. 
Medical care and clean water are often said to be insufficient. Many detainees suffer from gastroenteritis, dermatitis and depression (Meliala et al. 2011). Some former detainees have stated that they suffered physical and mental abuse from prison guards and fellow detainees during their time in detention. Given that most centres are understaffed, there have been several breakouts from detention centres (Abdurrahman 2010; Bambang 2010). When rearrested, detainees are often beaten by prison guards and occasionally by civilians involved in catching the escapees. Once recaptured, they usually face one to two weeks of solitary detention. Although the inmates of detention centres are officially not allowed to leave the premises, those who can afford to pay a small fee to the guards and are unlikely to run off can leave for an afternoon on their own. ${ }^{18}$ From interviews with former detainees, it became obvious that many guards expect tips, so those transit migrants who cannot afford the bribes to improve their supplies and level of comfort find life very difficult indeed.

According to the guidebook on human rights for the inmates of detention centres as issued by the board for research and development of human rights within the ministry of justice and human rights (2011: 41-51), while in detention, transit migrants are entitled to receive health care and proper food. They are allowed to contact their national consulates or embassies and their families to inform them about their detention. They are also allowed to receive or reject assistance from the national consulates. Furthermore, they have the right to receive visits from family members, sponsors, legal councils, spiritual leaders, doctors and state representatives. They have the right to practise their individual religions and beliefs. Finally, they are allowed to forward complaints to the guards. So far, however, there is no mechanism to check whether detention centre staff adhere to these regulations. Fear of the disciplinary consequences of human rights violations encourages authorities to press for the speedy release of detained transit migrants into local communities.

While more than half of the recorded transit migrants live in detention centres, the other half is allowed to live in local communities and interact more with local society (IOM 2011d). Families and unaccompanied minors are not supposed to stay in detention centres. As more and more under-aged asylum seekers arrive in Indonesia, special shelters have been set up for them. Until they turn 18 , unaccompanied minors can live there and receive a weekly allowance of Rp 120,000 (USD 12) to cover their expenses. Living in

18 Interviews with former and current detainees in Cipayung, Makassar and Kupang, June 2010 and November 2011. 
the local communities allows the transit migrants more mobility within a certain radius. Asylum seekers and refugees in local communities are supposed to register with the neighbourhood council and local police. Transit migrants found outside their assigned residential area can be returned to detention (Missbach \& Sinanu 2011).

While they wait for their status to be determined, asylum seekers have to live on their own savings or family remittances from overseas, either from their home country or other host countries. Therefore, it is no surprise to find many Western Union offices in the locations where transit migrants reside. Principally, as asylum seekers they are not entitled to financial support from the UNHCR unless they are highly vulnerable people, such as pregnant single mothers, in which case they will receive cash assistance, although this rarely exceeds Rp 1 million (USD 10o) per month. Once applicants have been recognised as genuine refugees, they are entitled to financial support. The UNHCR and its partner organisation generally provide Rp 1.2 million (USD 120) per family per month. In contrast, refugees and asylum seekers under the auspices of the IOM receive monthly allowances of between Rp 1 and 1.3 million (USD 100-130) per person, ${ }^{19}$ which is slightly more than the local minimum wage. Because of the variation in the payments and services people receive from the UNHCR, the IOM and other NGOs, social jealousy and resentment arises.

As asylum seekers and refugees have no right of residence, their presence is only tolerated. They also have no lawful access to the labour market and are officially not able to earn money (Matas 2012). Forbidden to work, transit migrants lose valuable skills, which is of particular concern to highly qualified people. Despite not having the right to paid work, some transit migrants do earn some money on the side, for example by baking and selling bread. One of the UNHCR's local counterparts established a community garden in Puncak where asylum seekers could farm vegetables for their own consumption and for sale (UNHCR 2007b). One man who regularly works there said that he earns between Rp 600,000 and 800,000 (USD 60-80) a month from growing water spinach. ${ }^{20}$ In a few cases, transit migrants who have lived in Indonesia for a long time have opened small grocery stores, although this requires the cooperation of Indonesian middlemen.

While waiting for the outcome of the asylum applications and resettlement, transit migrants face debilitating boredom and occasionally social marginalisation. Generally, public perception of transit migrants is char- 
acterised by a lack of sympathy. Transit migrants face racist stereotyping, and social tension between them and local residents has been reported on a number of occasions, especially arising from extramarital affairs. Media and state officials blame transit migrants for being involved in the drug trade (UNHCR harus waspadai warga Iran 2012). Moreover, some transit migrants who have stayed in Indonesia for a prolonged period of time have been suspected of involvement in facilitating people-smuggling operations (Munro 2011). Given their extensive local knowledge and networks, it is highly likely that people-smuggling in Indonesia is organised by certain transit migrants along ethnic affiliations (Missbach \& Sinanu 2011).

Access to formal education while living in transit still remains a challenge, even though, in response to requests from the UNHCR, local education authorities have agreed to allow children of recognised refugees to attend primary schools. Unlike the children of recognised refugees, children of asylum seekers are officially not allowed to go to school. However, some parents manage to get their children registered. the UNHCR implementation partner in Puncak provides very welcome weekly computer and language training (English and Indonesian) for adult asylum seekers and refugees and their children, but these classes cannot be a substitute for more formal education. Under-aged asylum seekers are also allowed to attend English classes at private language institutes, but the UNHCR only covers their fees until they turn 18 . Theoretically, to use their time in waiting wisely, asylum seekers and refugees can enrol in university if they are able to cover the fees or receive a scholarship. In regard to resettlement options, destination countries prefer highly-educated refugees and value those who have taken proactive steps to gain more education. However, those who are currently enrolled in university programmes are not eligible for immediate resettlement, so in this regard transit migrants are caught in a catch-22 situation. ${ }^{21}$ All in all, transit migrants living in the local communities are better off than those in detention centres.

\section{Criminalisation and/or human rights protection?}

Transit migrants in Indonesia are stuck between a rock and a hard place, as they can neither move forward to where they wish to go nor easily return to where they came from. To make matters worse, even staying in Indonesia is 
problematic. The findings of this chapter are consistent with the conclusions of a survey by the Jesuit Refugee Service which notes:

Protection space for asylum seekers and refugees in South-East Asia is limited and consistently changing. It is in this dynamic environment that asylum seekers and refugees must negotiate complex, protracted and non-transparent processes. (Jesuit Refugee Service Asia Pacific 2012: 63)

The Australian government has been putting pressure on Indonesia to minimise and prevent the passage of unwanted asylum seekers to Australian territory, thus discouraging Indonesia from simply allowing transit migrants to travel through the archipelago unhindered. Australian immigration officers are based at all Indonesian international airports to help identify fraudulent documentation of travellers planning to come to Australia (Australian DIMIA 2002). Australia has equipped its Indonesian counterparts with intelligence technologies to survey the movements of transit migrants more closely. Moreover, in late 2011, as part of a new policy initiative to enhance regional law-enforcement capacity, the Australian federal police donated three new high-speed patrol boats worth AUSD 7.1 million to the Indonesian maritime police (New Indonesian patrol boats 2011). In the first half of 2011, Indonesian maritime police vessels, which are small and not normally ocean-going, intercepted more than fifty migrant-smuggling boats in Indonesian waters (IOM 2011a). There have been considerably more interceptions on land. With more transit migrants coming to Indonesia and more arrests, Indonesia's detention centres, which only have the capacity for 1,300 detainees altogether, have long reached their limits.

However, the more Indonesia complies with Australia's desire to deter the movement of transit migrants, the greater the dilemma that Indonesia faces. This chapter has revealed the extent to which Indonesian authorities are overwhelmed with the increasing inflow of transit migrants. Unwilling to become a dumping ground (tempat penampungan) for unwanted asylum seekers, Indonesia is unable to house all those who have been intercepted without proper documents, as its detention centres are already overcrowded. Critics of the detention of asylum seekers, such as the UNHCR, favour temporary settlement in local communities but, as discussed, this creates another set of problems. Tired of waiting for the completion of the slow status-determination procedure or resettlement, transit migrants continue to opt for the risks of 'self-organised' onward migration by boat. Many fail. Between 2001 and 2012, more than 1,000 people drowned attempting to reach Australia irregularly (Hutton 2012). Many more are intercepted and put back 
into detention; some have experienced this 'cat-and-mouse-game' with the police several times. Each attempt costs transit migrants more money, causing them to pile up huge debts to be repaid one day. As there is no legislative provision in Indonesia for anything other than the indefinite detention of undocumented people, transit migrants will continue to set sail for Australian territory as soon as they find the slimmest chance of getting there arises.

Indonesia cannot vacillate on this issue much longer, as transit migration involves more and more Indonesian actors. More than 500 Indonesian fishermen, a fifth of them under-aged, have been detained and convicted for people smuggling in Australia (Abbas 2011; Gordon 2012). The number of convicted people smugglers in Indonesia is also on the rise since the enactment of the Law on Immigration 6/2011 which contains special sections for penalising people smuggling (Crouch \& Missbach 2013). Indonesian officials many see their own colleagues falling victim to the transit migration industry, as poorly paid officials within immigration services, the military and the police become involved in people smuggling (Police officers probed 2012). Even people who do not try to benefit from people smuggling may still face negative consequences. For example, detention guards and security personnel are subject to disciplinary measures and career setbacks each time a detainee escapes. The motivation to arrest undocumented transit migrants is, therefore, decreasing. Yet, at the same time, the lenient sentences for those guards who violate the rights of asylum seekers and refugees reflect a certain disinterest in the overall issue of refugee protection. In the case of Taqi Nekoyee, whose case was described at the beginning of this chapter, the guards found responsible for his violent death only received ten months' imprisonment (Missbach \& Sinanu 2013).

So far, the issue of transit migrants is not seen as a high priority in Indonesian politics. Although Indonesian ministries are currently drafting a manual of standard procedures for handling undocumented asylum seekers with more attention to the protection of their human rights, officials involved keep stressing that the Indonesian government faces many more serious challenges, thus affording low priority to the issue of asylum seekers. In the words of Masni Eriza, deputy director of humanitarian affairs at the ministry of foreign affairs: ${ }^{22}$

I think it is quite understandable that, since the number of refugees from overseas is still moderate, we and the officials from other relevant ministries do not see this issue as pressing priority. Even if the real numbers 
of people of concern are five or six times higher than 3,000, that is still nothing compared to the 100,000 in Malaysia.

Despite this indifference, immigration officers at the operational level keep urging the government to prevent, first of all, transit migrants coming into Indonesia directly or via Malaysia by limiting the issuing of visas to potential transit migrants (from places such as Iran) on their arrival and by controlling airports and harbours more strictly. Controlling the Indonesian coastline for undocumented arrivals, however, is not just expensive but almost impossible, given that it is more than 80,000 kilometres long. Immigration authorities are asking the relevant government agencies to launch more awareness campaigns among coastal Indonesian communities so that the people most susceptible for people smugglers' offers do not become the henchmen of international syndicates. Efforts such as these are very costly, and Indonesia therefore expects Australia to contribute. However, it is doubtful that such measures serve the well-being of present and future transit migrants in Indonesia, many of whom are not only asylum seekers but also refugees. Preventing transit migrants from entering and leaving Indonesia will not ensure the protection of their rights, especially if they are held in Indonesian detention centres for the long term. If Indonesia and Australia are interested in providing protection to people in need, they have to rethink entirely the way that transit migrants are currently treated.

My sincere thanks to Marshall Clark, Annett Fleischer, Dave McRae, Frieda Sinanu and Anne Looker for their critical comments. I also would like to acknowledge the financial support of the Fritz Thyssen Stiftung and the Melbourne Law School that enabled me to conduct fieldwork in Indonesia. Needless to say, all remaining mistakes are my own responsibility. 



\section{Abrogating human rights responsibilities}

Australia's asylum-seeker policy at home and abroad

Linda Briskman \& Victoria Mason

\section{Introduction}

Australia's approach to asylum seekers is a contested area of public policy and has been subjected to ongoing critique by human rights bodies, nongovernmental organisations (NGOs) and refugee advocates both at home and abroad. In 2012, after two decades of mandatory immigration detention, Australia remained far from addressing criticism and presenting alternative policy formulations that adhere to its obligations as a signatory to the Refugee Convention of 1951 and other international instruments. Developing a regional approach is a concept that is gaining traction among academics, NGOs and other actors. Despite some incremental advancement, the Regional Cooperation Framework (RCF) is currently a work-in-progress, as will be outlined later in this chapter. Furthermore, the continuation of harsh domestic policies towards asylum seekers, the reconstruction of offshore processing through bilateral arrangements and the ideologies that allow such measures to be in place need resolution if the RCF is to be a credible policy initiative.

To set the context for the discussion in this chapter, we first examine the restrictive asylum policies in Australia - particularly mandatory detention - and argue that the policies have been maintained and extended through the construction of a 'politics of fear' based on racism. We then explore the political questions of how border security is prioritised over human security, including the 'stop the boats' discourse and the 'war' on people smugglers. We also engage in some discussion of how 'pull' factors are emphasised in populist representations with little emphasis on 'push' factors, that is, the factors that precipitate people movements. Finally, we present an outline of the RCF, contextualised by a discussion on how it is one of Australia's emerging policy initiatives and one that will require a move away from what has been a preference for bilateral arrangements. 


\section{Asylum-seeker policy framework: The entrenchment of mandatory detention}

A raft of measures enshrines Australia's approach to asylum seekers, with mandatory detention at its centre. Yet not only does mandatory detention deny the most basic of human rights - liberty - for people who exercise their lawful right to seek asylum, but long-term detention, abusive practices within detention facilities and mental health outcomes - including suicides and acts of self-harm - also substantiate the malevolence of this policy. Despite the evidence before it, successive governments have been unwilling to repeal the mandatory detention provision.

Australia is not the only country to incarcerate asylum seekers; many countries detain them, with the practice appearing in different guises around the globe. Australia, in its quest for orderly migration, is particularly harsh, especially given that the numbers fleeing to its shores are relatively low. The practices of detention express unfettered sovereign power, and Australia makes the claim of absolute sovereignty over its borders through its mandatory detention policies and the location of detention centres in remote and hostile sites (Weber \& Pickering 2011).

As it is in many Western nations that are signatory to the $195^{1}$ Refugee Convention, asylum seeking is a contested political issue in Australia, triggering strong opinions both in support of and against asylum-seeker entry. In Australia, the mandatory detention policy has bipartisan support, which means there is little leverage at the formal political level. Over the past 20 years, successive Australian governments have taken increasingly regressive steps in an effort to deter asylum seekers. Following a sharp increase in arrivals from an average of 312 people per year between 1989 and 1998 to 3,721 in 1999 (Phillips \& Spinks 2012), the Coalition government introduced Temporary Protection Visas (TPVs) in September 1999. TPVs limited the rights of asylum seekers, most significantly by prohibiting family reunion. This effectively ensured that families had no opportunity for lawful reunion and resulted in a significant increase in the numbers of women and children making the dangerous journey by boat in order to reunite with husbands and fathers who had come earlier. The SIEV X tragedy (SIEV = Suspected Illegal Entry Vessel) of 2001 in which 353 people (142 of them women and 146 children) drowned while attempting to reach Australia brought the human cost of the TPV into sharp focus.

The mandatory detention regime that could cope with a few hundred boat arrivals was unable to manage increased numbers. In 2000, when there were 2,937 boat arrivals, both sides of the political spectrum presented 
this as a national emergency and media coverage surged dramatically (Marr \&Wilkinson 2004: 56). The growth in detention numbers did not halt the inflow of boats. With both detention and TPVs failing to operate as deterrents, and with increasing pressure on immigration facilities, where there are frequent acts of self-harm, attempted suicides, hunger strikes and protests, the government desperately needed another deterrent. The opportunity to introduce more aggressive policy measures arose with the Tampa event in 2001, which is covered below, as Tampa proved to be pivotal in bringing about a trajectory of policy processes that came to characterise the Australian approach towards the deterrence of asylum seekers.

\section{A turning point: Tampa}

On 26 August 2001, the Norwegian freighter MV Tampa rescued 438 mainly Afghan asylum seekers from a sinking boat, the Palapa, between Indonesia and Christmas Island, an Australian territory in the Indian Ocean. Notwithstanding the desperate situation of the human cargo on board and despite Tampa's captain Arne Rinnan's pleas to be allowed to land, the Australian government not only refused his request but deployed military measures to keep the vessel from docking. The incident raised major concerns in relation to Australia's international obligations not just to asylum seekers but to international norms relating to rescue at sea. What happened next was critical in reshaping and hardening Australia's policies.

In a reactive tactic that caught many unaware, the prime minister at the time, John Howard, struck a deal with the government of Nauru which meant that, apart from 150 accepted by New Zealand, the rest of the asylum seekers aboard the Tampa were transported to a detention site on Nauru, a practice that was heavily criticised by NGOs and human rights bodies (see, for example, Bem et al. 2007; Amnesty International 2007). Nauru was the start of the Pacific Solution and was joined soon after by Papua New Guinea, which opened a detention facility on Manus Island. In the same year, legislation was formulated that officially removed some Australian islands from Australia's migration zone to prevent people arriving at those islands from applying for visas unless permitted by the immigration minister. In 2005, thousands more islands were excluded from the migration zone.

The way the government handled the Tampa incident was supported by many Australians who were duped into believing that Tampa illustrated that Australia's borders were in need of protection. The incident helped Prime Minister Howard to reverse his flagging popularity to win an elec- 
tion in November 2001, sometimes referred to as the 'Tampa election'. The 9/11 attacks in the United States one month following Tampa galvanised increased support for border protection. The Tampa event clearly illustrates the country's attempts to define itself as a sovereign nation that unilaterally determines who can enter. It also marked the beginning of offshore bilateral arrangements that diminished Australia's responsibility for providing safe haven and ran counter to the idea of regional cooperation.

An extensive asylum-seeker 'industry' has taken hold in Australia, with a network of detention facilities operating throughout the country. One only had to set foot on Christmas Island during the peak of asylum seeker detention on that island in 2010 and 2011 to be confronted by the presence of immigration officials, corporatised detention services, fly-in/fly-out operatives and military and police personnel. The largest vested interest is the security company that runs immigration detention centres in Australia, Serco, which took over from two previous private detention providers. Given the profit motive and the drive to expand nationally and internationally, it is in the interests of multinational security entities that the policies are perpetuated and not challenged. The presence of the companies serves the interest of governments to demonstrate to voters that they are enforcing tough immigration laws (Bernstein 2011). Despite the well-documented harms arising from detention (Briskman, Latham \& Goddard 2008) and despite the evidence of poor practices within detention facilities, their operation by private companies continues unabated.

How did Australia reach a state of affairs in which its policies and practices have been antithetical to human rights? Questions of race and fear offer an explanation.

\section{Interrogating race and fear}

The fear of 'The Boat' that has taken hold in Australia conjures up societal anxiety about Islam, terror and the undermining of the dominant way of life (Briskman 2012). The government and an insatiable media have driven this fear. In 2001, former Defence Minister Peter Reith spoke on commercial radio soon after $9 / 11$ advocating the need to control people who come into the country. 'Otherwise', he argued, 'it can be a pipeline for terrorists to come in and use your country as a staging post for terrorist activities

... if you can't control who comes into your country then it is a security issue' (Reith 2001). Such statements reinforce community apprehension so that governments can manipulate the fear of terrorism for political aims 
(Aly 2011), in this case justifying stringent border security measures and immigration detention.

Underlying the complexities is, arguably, the issue of racism. Would Australia treat Western nation-states and nationals from Western countries in the way it deals with those designated as the racialised 'Other'? Racialised approaches are not surprising given the building of the nation and national identity on the destruction of Aboriginal society and through the White Australia Policy. ${ }^{1}$ Nation-building on a singular notion of identity has led to a belief that cultural norms are at risk from immigrants. It has particularly played itself out with Muslim asylum seekers who have been homogenised, demonised and labelled as fundamentalists and would-be terrorists (Poynting \& Mason 2006, 2007, 2008). The ideological racial underpinnings of the nation shift over time but the undercurrents remain substantially the same, formulated around an entrenched belief in the incapacity of those assigned to the Other to be absorbed into Western societies, as their value base is seen to be at odds with the value systems in these countries (Kundnani 2007).

Australia has been enacting its own brand of border protection since the British colonial presence, which had been premised on racialised exclusions (Tascon 2010). Two factors are influential in Australia's positioning: its location among largely Asian nations and its own epistemological origins, which are in a direct line from the European Enlightenment (Tascon 2010; Poynting \& Mason 2007). A problem in Australia throughout the history of White Australia that is relevant to the current issue of asylum seekers is, according to Anthony Burke, that the 'imagined community' is one that is 'bounded by a power which seeks to enforce sameness, repress diversity and diminish the rights ... of those who are thrust outside its protective embrace' (2001: xxiv).

Grewcock (2009) speaks of a manufactured crisis that has made border protection a defining concept invoking fears of a foreign invasion, with an emphasis on how 'illegal' refugee entry threatens both the integrity of the state's refugee programme and national security. A 'politics of fear' has taken hold, which morphs into what Burke describes as 'invasion anxiety' (2001). It is in 'anxious times' that sovereignty is jealously guarded by the wielding of an iron fist against those who cross borders uninvited (Zagor 2007). The distortion of the events of $9 / 11$ by Australia is puzzling, given that it has not directly experienced terrorist attacks. The hostility and threat

1 One of the first Acts of Parliament passed after the Federation of Australia was the Immigration Restriction Act (1901), better known as the White Australia Policy, which allowed only Europeans to enter Australia. 
scenario generated in Australia following 9/11 was an imagined threat, and the intense reaction became linked with the anxiety that had already taken hold, namely unauthorised asylum seekers arriving by boat (Tascon 2010).

A convenient connection was made by the Australian government between asylum seekers and terrorists in public discourse, with Muslim asylum seekers portrayed as a group to be feared and not deserving of assistance from Australia (Babacan \& Gopalkrishnan 2008; Poynting \& Mason 2006). Globally, immigrant groups have been targeted in times of national security crisis. The $9 / 11$ attacks, the 2004 Madrid bombings and the 2005 London transit attacks inflamed the view of Islam as the 'enemy', with the 9/11 attacks in particular demonstrating the tensions between security, immigration and the rights of minorities (Monshipouri 2010; Poynting \& Mason 2006). Ghassan Hage argues that $9 / 11$ 'sealed the position of the Muslim as the unquestionable Other in Australia today' (2003: 67). The 'Middle Eastern Muslim Asylum Seeker' has entered the Australian lexicon as derogatory terminology.

In its denunciation of Islam, Australia is somewhat polarised between two competing ideologies: the importance of maintaining the dominant Christian identity, and a vision of a secular society. Almost half of the world's sixteen million refugees come from Muslim countries, and some are now resident in Australia. Yet, even though Muslims are less than two percent of the Australian population and come from diverse countries and cultural backgrounds, as Poynting \& Noble (2004) point out, being Muslim is seen as a singular category by the mainstream.

Although Australia does not have the same right-wing political movements as other Western countries, particularly in Europe, this status was seriously challenged in 1997 when Pauline Hanson launched her One Nation Party and conducted strident and ill-informed attacks on Aboriginal peoples, Asian migration and multicultural policy (Stratton 1998: 9). Although Hanson and her party are no longer influential, there is little doubt that key elements of her platform have been seized by mainstream politics and incorporated into racially constructed policies that present a disjuncture with an espoused commitment to multiculturalism. As Marr (2011: 441) observes, 'panic forbids retreat', adding that 'If there had been a political contest about the boats, measures that were merely punitive and doing nothing to stem the flow might have been done away with'. Given the above factors, it is not surprising that border security has become a national priority in Australia. 


\section{State border security versus human security}

Although some commentators have forecast the dawning of a borderless world, the borders of nation-states are very much alive (Weber \& Pickering 2011). Australia's strident emphasis on border security as opposed to human security in its refugee and asylum-seeker policy is part of a broader problematic paradigm reinforcing 'the assumption that state sovereignty as we know it ... is part of a natural or necessary order of things' and that displacement is 'an anomaly in the life of an otherwise "whole," stable, sedentary society' (Malkki 1992: 33). In this state-centred approach, refugees - and particularly asylum seekers who utilise irregular migration - are seen as a 'threat' to the 'natural' order (Malkki 1995: 508). The blame for, and threat posed by, their displacement is then internalised within the refugee (Malkki 1992; Arendt 1973). As Malkki suggests, rather than focusing on the 'processes that produce massive territorial displacements of people', the threat is framed as being 'within the bodies and minds (and even souls) of people categorized as refugees'. As a result, the refugee becomes pathologised and criminalised, and refugees are regarded as 'no longer trustworthy as "honest citizens"'. They are regarded as 'carriers of conflict', 'suspected of political irresponsibility that endangers national security', deemed to be prone to 'sink into the underworld of terrorism and political crime'; and 'basically amoral ... dangerous characters' (Malkki 1992: 32; Peteet 2007; Mason 2011). Once asylum seekers are pathologised and criminalised in this way, this then 'naturalizes and renders reasonable the sealing of borders against applications for asylum' (Malkki 1995: 508).

A key part of this demonisation and marginalisation of asylum seekers has been the utilisation of the discourse of 'hospitality' to justify the rejection of irregular migrants in need of sanctuary (Mason 2011). Scholars such as Gibson have explored the link between hospitality and nationalism, whereby 'the metaphors of generosity or hospitality enable the reassertion of the sovereignty of the nation-state' (Gibson 2007:163). In such metaphors, the refugee or immigrant is 'imagined as "the guest" and 'the "host nation" maintains its historical position of power and privilege in determining who is or is not welcome to enter the country, but also under what conditions of entry' (Germann Molz \& Gibson 2007: 8-9). Thus, while the 'host' state often 'imagines itself narcissistically as being hospitable', the reality is that 'hospitality' becomes a means of controlling and excluding (Germann Molz \& Gibson 2007; Mason 2011).

In this vein, Australia presents itself as being 'hospitable' to migrants and refugees who go through formal migration channels and frames the 
asylum seeker as the 'uninvited' intruder who is seeking to take advantage of Australia's 'generosity'. This approach fails to critique the deeply flawed notion that an orderly global 'queue' exists through which refugees can seek sanctuary and enables Australia to present itself as the victim of the dangerous and 'parasitical' asylum seeker who arrives through irregular means (Laachir 2007; Germann Molz \& Gibson 2007; Mason 2011).

This political discourse has resulted in asylum-seeker policies and practices in Australia focusing on militarisation and deterrence rather than on humanitarian considerations. This was particularly evident from late 2001 until 2006 when Operation Relex was introduced and implemented by the Coalition government. Relex was a strategy involving a range of government authorities to actively prevent boat arrivals from reaching Australia (Chambers 2010). Boat arrivals diminished during this period, but the number of boats that were intercepted and turned back under this interdiction policy is not known. Furthermore, 1,6oo asylum seekers who attempted to come were diverted to Manus Island or Nauru during this period; they were attempting to come to Australia (Rintoul 2011). The decline in the number of asylum seekers that did occur can be explained by 'push' factors, as globally the number of Afghan asylum seekers declined from 2001. Australia's stringent measures defies the geographic locality of the nation, for, in reality:

no country in the world has greater control over its borders than Australia ... While most countries share at least one border with another country and usually many more, Australia is an island continent with vast surrounding seas and these natural barriers make irregular migration extremely difficult. (ASRC 2011)

The investment of funds in border protection agencies and in remote immigration detention facilities illustrates the priority that Australia places on protecting its borders from those seeking safe haven. The conflation of asylum-seeking with terrorism opens the way for the development of zones of exclusion and the differential treatment of those assigned the label of 'non-citizen'. Border Protection Command, entrusted with the security of Australia's offshore maritime areas, specifies that Australia's national interests are threatened by any unauthorised arrival of people (BPC undated).

The costs of implementing border control appear to be of scant concern. In its 2010-2011 Budget on Border Protection and Detention, the government announced that, in addition to its previous allocation of AUD 654 million to 
border security and the prevention of people smuggling, a further AUD 1.2 billion was to be allocated 'to bolster Australia's border security'. In so doing, the federal government stated that it had 'been under increasing pressure to further address people smuggling issues due to a significant rise in the number of unauthorized boat arrivals' (Phillips \& Karlsen 2010). Similarly, money appears to be of no concern in maintaining the network of detention facilities in Australia. Bernard Keane (2011) suggests that 'Australia's fixation with asylum seekers arriving by boat has cost taxpayers nearly $\$ 2.4$ billion since 2000', not including the cost of Nauru or the border security measures themselves. The cost of constructing and upgrading the Christmas Island facility was more than AUD 300 million (Keane 2011). Furthermore, the remoteness of the Christmas Island detention facility means that it relies on a fly-in/fly-out workforce, resulting in high expenses for flights, accommodation and food. Other remote centres such as the Curtin facility in the far north of Western Australia also require substantial expenditure in the quest to keep asylum seekers away from populated mainland cities.

Alongside government strategies affecting asylum seekers are policies against people smuggling that illustrate the lengths the government will go to operationalise the 'stop the boats' refrain that has taken hold (see chapter 10 in this volume). The emphasis on stopping people-smuggling ventures has been cast in binary terms - by government as an evil trade that exploits vulnerable people and by some advocates as a necessary industry that provides opportunities for the pursuit of a life free from persecution.

Unlike people smugglers who rescued people at risk of death during the Nazi Holocaust, smugglers assisting asylum seekers in their journey to Australia are given pejorative descriptions (see chapter 7 in this volume). Although the demonisation of the smuggler has been consistently present in government discourse, it became starker after the Labor Party took over government in 2007 when the language towards asylum seekers softened and the criminalisation of their agents became more apparent. The gettough approach is codified in the punishment regime of Australian law, not just for journey organisers but also for the boat crew (see chapter 10 in this volume). The mandatory five-year prison sentences result in the incarceration of Indonesian nationals in Australian prisons. Most of the crew are unaware of the nature of their undertaking and are lured by small amounts of money. They are usually recruited from impoverished Indonesian fishing villages and are paid little by the organisers (Smit 2011).

The prioritising of border security minimises the paradigm of human security. Lester (2010) advocates the people-centred approach of human security, which locates the human being, rather than the state, at the 
centre of its concern. She states that the traditional debate on national or international security fails to take into account the threats to the protection and security of the individual human being. The lack of emphasis in the public domain on factors that create people movements generates the false belief that it is Australia that is the lure for such movements, resulting in a tension between factors of 'push' and 'pull'.

\section{Push and pull}

The movements of people seeking asylum are often referred to in terms of 'push' and 'pull' factors. According to Flitton (2012), the so-called 'push factors' that drive people to make the harrowing choice to abandon their home are generally swamped by allegations about the 'pull factors' - of Australia as a holiday-like destination, with smugglers as malevolent travel agents. In the contemporary political discourse, the emphasis is almost solely on 'pull' factors, particularly with conservative Coalition parties arguing that the Labor government's 'soft' approaches encouraged the arrival of boats in Australian waters. The reality is that the deterrence measures that have infused Australia's approach have failed to achieve their objectives, as desperate people will continue to seek ways of securing a safe life for themselves and their families.

A cursory examination of Iraqis and Afghans, whose applications for asylum in Australia in the last decade have been prominent in media reports of irregular migration, demonstrates the importance of 'push' rather than 'pull' factors in the rationale of people deciding to make the perilous journey by sea to seek refuge in Australia.

As a result of the intense violence of the 2003 US-led occupation of Iraq and the subsequent insurgency and humanitarian crisis, around 4.7 million Iraqis have been displaced. Around 2.7 million have been internally displaced within Iraq, of whom an estimated one million remain displaced. Another two million have fled to neighbouring Arab states to seek refuge; it is estimated that since 2003, Syria has hosted around 450,000 to 1.4 million Iraqi refugees; Jordan 500,000 to 700,000; Egypt 30,000 to 70,000; and Lebanon 20,000 to 40,000 (UNHCR 2012e, 2010; Amnesty International 2008; Human Rights Watch 2006).

The situation for Iraqis within Iraq remains highly problematic. While violence has decreased from previous peaks in recent years, Iraqis still endure high levels of violence, including daily bomb attacks and the targeting of particular groups such as minorities and professionals (BBC News 
26 April 2012; Tripp 2012; Jakes 2012). A lack of basic services, the widespread destruction of infrastructure and high unemployment have also made everyday life very difficult for many Iraqis (UNHCR 2012e; Al Tikriti 2010). According to the United Nations High Commissioner for Refugees, of the one million Iraqis who remain internally displaced, 'hundreds of thousands live in dire conditions. Most are unable to return to their areas of origin because of the volatile security situation, the destruction of their homes, or lack of access to services' (UNHCR 2012e). Thus, although Western media coverage of the situation in Iraq may have subsided, Iraq is not yet stable or safe.

The Iraqis who fled and sought sanctuary outside Iraq also continue to face precarious situations. Most of the neighbouring states that have hosted displaced Iraqis are not signatories to the Refugee Convention; the exception is Egypt, which is a signatory but with significant reservations. As a result, most Iraqi refugees have entered these neighbouring states as temporary 'visitors', which means their legal status is precarious and their security, long-term protection and access to services are severely limited (Mason 2011). Although many of these Iraqis have now been in these host states for a number of years, they are not able to legally work and have used up any savings they may have had. Their only option is to work illegally in the informal economy, leaving them open to exploitation and possible deportation. Iraqi refugees have also encountered struggles accessing core amenities and services, including schooling for children and healthcare (Mason 2011). Living in such a tenuous situation has exacerbated the intense psychosocial problems experienced by many Iraqi refugees, as described in a report by the International Organization of Migration (IOM):

For those who had experienced direct violent attacks - 21 percent of the refugee sample in Jordan and 34 percent in Lebanon - including witnessing assassinations of relatives and friends, torture, rape or kidnappings, psychological distress was overwhelming. The insecurity of their refugee life, a lack of employment and the de-professionalization of Iraqis whose qualifications are unrecognized, poor living conditions and access to health and social services, including education, have further aggravated the situation, particularly among Iraqis who have been displaced for two years or longer. (2008a)

In the wake of the global financial crisis, Iraqi refugees have become scapegoats for spiraling economic (and thus social and political) problems in the states that have hosted them, and there has been increasing pressure for them to return to Iraq. Iraqis have, moreover, been affected by the recent 
violence in Syria, with a number of Iraqis fleeing the situation there, and more seeking refuge in Jordan, even though Jordan has enforced tough visa procedures since 2006 (UNHCR 2012e; Mason 2011).

While the Iraqi government has attempted to encourage refugees to return to their homeland at various stages, large-scale repatriation has yet to occur because of the continuing instability and violence. Furthermore, many refugees have lost most, if not all, of what they owned in Iraq, which, in combination with the lack of basic services and the widespread destruction of infrastructure in Iraq, means they have very little to return to (UNHCR 2012e; Amnesty International 2008; International Crisis Group 2008). Indeed, as the UNHCR notes, the conditions in Iraq 'have not only restricted the level of voluntary returns, but have triggered continued outflows to neighbouring States' (2012e). Consequently, Iraqi refugees in neighbouring states have been left in an abyss of sorts, where their future is extremely uncertain. As they cannot remain in their host countries for the long term and cannot return to Iraq, many see third-country resettlement as their only option. Yet, there have been few opportunities for third-country resettlement through formal channels, including in those countries which arguably have a moral imperative to assist displaced Iraqis because of their role in the invasion of Iraq - the United States, the United Kingdom and Australia (Human Rights Watch 2006; Amnesty International 2008). The desperate situation this has placed many Iraqis in is a key reason why so many have been forced to resort to irregular means of getting their families to safety.

Afghans have also been prominently reported on in media coverage of asylum seekers in Australia, particularly in the last ten years. Afghanistan has suffered from decades of conflict, particularly as a result of the 1979 Soviet occupation, Taliban rule and the 2001 US-led war and subsequent occupation. Millions of Afghans have been displaced, meaning that Afghanistan continues to be a major source country for refugees (UNHCR 2012b).The situation in Afghanistan today remains highly volatile. While the Taliban were formally ousted from power in 2001, the Afghan government has achieved only variable levels of control outside the major urban centres, and according to the International Crisis Group the Taliban and a range of warlords have been steadily reasserting their influence (2012):

The insurgency in Afghanistan has expanded far beyond its stronghold in the south east. Transcending its traditional Pashtun base, the Taliban is bolstering its influence in the central-eastern provinces by installing shadow governments and tapping into the vulnerabilities of a central government crippled by corruption and deeply dependent on a corrosive 
war economy. Collusion between insurgents and corrupt government officials in Kabul and the nearby provinces has increased, leading to a profusion of criminal networks in the Afghan heartland. Despite efforts to combat the insurgency in the south, stability in the centre has steadily eroded ... A little more than a year after the transfer of additional U.S. troops was completed, violence increased across the country, hitting new peaks in May 2011 as the Taliban launched their spring offensive, which resulted in the highest recorded number of civilian casualties incurred in a single month since the U.S. engagement in Afghanistan began in 2001. It is unlikely that this trend will be reversed anytime soon. (2011)

This reality, plus the ongoing foreign occupation, has resulted in continuing high levels of violence, insecurity, and political, social and economic turmoil, including high levels of poverty and unemployment (Refugees International 2012). This has resulted in the ongoing displacement of Afghans, with 2011 alone seeing 'a rapid increase in conflict-induced internal displacement in Afghanistan, creating nearly 100,000 new IDPs [internally displaced persons]' (UNHCR 2012a). Overall, the UNHCR estimated that in 2012 around 1.3 million Afghans within the country were asylum seekers, refugees, returning refugees and internally displaced persons (UNHCR 2012a).

Despite the ongoing violence, it is estimated that approximately $5.7 \mathrm{mil}$ lion refugees have returned to their homeland since 2002. Those returning have often experienced very difficult conditions. Studies of refugees who repatriated to Afghanistan (Saito \& Kantor 2010: Kamal 2010) have found that many have been deeply affected by the ongoing violence and instability in Afghanistan and have faced serious socioeconomic challenges. Moreover, they often experience discrimination by Afghans who remained in the homeland. The refugees are deeply concerned by the more religiously fundamentalist environment in Afghanistan The UNHCR notes that 'more than 40 percent of returnees have not reintegrated into their home communities ... Specific areas needing improvement include land tenure and housing, livelihood opportunities, and access to public services and water' (2012a). Saito and Kantor also describe the immense adversities specifically facing women returnees, highlighting issues such as:

an unfavourable environment with decreased mobility because of security issues (for example harassment and kidnapping), more restrictive social norms, and unavailability of facilities (for example, lack of secure public transportation). For economically vulnerable female returnees ... 
few acceptable work options existed ... A few female respondents reported experiencing brutal domestic violence ... this led them to perceive deficiencies in the Afghan legal system compared to Pakistan or Iran. (2010: 138; see also Kamal 2010)

As a result of the tenuous situation in Afghanistan, repatriations have slowed since 2007, and many Afghans have once again fled the violence and instability of their homeland. Some 2.7 million Afghan refugees remain displaced in the region, with 1.7 million in Pakistan and one million in Iran (UNHCR 2012a). Although both Pakistan and Iran have a history of hosting Afghan refugees that goes back over thirty years, during which they have had very little international support, Afghans live in both countries with varying and often precarious degrees of legal status and rights (Saito \& Kantor 2010; Kamal 2010).

Pakistan is not a signatory to the Refugee Convention and, while Afghan refugees have been able to access strong Afghan support networks in areas of Pakistan such as Quetta in Baluchistan, refugees in general 'have difficulty in accessing basic facilities and essential services including education, health care and work' (UNHCR 2012c; Monsutti 2010: 57 ). Since the fall of the Taliban, Pakistan has undertaken a range of measures that prepare the way for the large-scale repatriation of Afghan refugees.

Although Iran has also hosted a substantial refugee population for decades, the Islamic Republic signed an agreement with the Afghan government and the UNHCR in 2003 to facilitate the voluntary repatriation of Afghans. At the same time, Iran passed legislation that 'outlawed employment, administrative services, banking, participation in civil society, and accommodation for Afghans without valid residence permits' in order to 'encourage' repatriation (Kamal 2010: 150). Thus Afghans in Pakistan and Iran face a situation that is similar to that of Iraqis hosted by neighbouring Arab states: they cannot remain in their host states for the long term and it is not safe for them to return to their homeland. The fact that opportunities for third-country resettlement of Afghans have contracted considerably following the 2001 war further limits their options.

Understanding the 'push' factors, particularly in terms of the levels of violence and insecurity in their home and host countries, is thus essential in the consideration of why Afghans and Iraqis feel they have no other option but to undertake the treacherous journey to seek asylum in Australia. As Table 8.1 indicates, the peaks and troughs in the number of Iraqis and Afghans seeking asylum in Australia strongly correlate with shifts in their respective security situations. 
Table 8.1 Asylum applications in Australia from Iraqis and Afghans

\begin{tabular}{lccccccccc}
\hline & $\mathbf{2 0 0 3}$ & $\mathbf{2 0 0 4}$ & $\mathbf{2 0 0 5}$ & $\mathbf{2 0 0 6}$ & $\mathbf{2 0 0 7}$ & $\mathbf{2 0 0 8}$ & $\mathbf{2 0 0 9}$ & $\mathbf{2 0 1 0}$ & $\mathbf{2 0 1 1}$ \\
\hline Iraq & 1,433 & 231 & 221 & 380 & 216 & 193 & 303 & 379 & 491 \\
Afghanistan & 2,359 & 757 & 928 & 699 & 20 & 52 & 936 & 1,262 & 1,721 \\
\hline
\end{tabular}

Source: UNHCR (2005a, 2006, 2007a, 2008, 2009, 2011a, 2012b)

Research conducted on asylum seekers' destination preferences (Richardson 2008; Gradstein 2006) has revealed that asylum seekers have not chosen Australia specifically and that most had little knowledge of Australia's policies before arrival. People smugglers were found to be the most influential factor in the selection of destination. Taylor makes a salient point about the search for safe haven based on research she conducted with Sandra Gifford between 2007 and 2009:

We discovered that asylum seekers and refugees don't necessarily want to make Australia their home. They just want to have a home - a place where they can live in safety, support themselves with dignity, give their children a future through education, and belong. The knowledge that they had a realistic prospect of being resettled in a country that could fulfil these needs would have been enough to enable them to bear shortterm insecurity. In fact, if these basic human needs could be fulfilled in Indonesia, they would have been happy to settle there. Unfortunately, neither a home in its true meaning nor the hope of one in the future can be found in Indonesia, or in most other countries in our region. Australia is one of the few exceptions to that rule. (2011b)

Similarly, Amnesty International reported that in Malaysia, a key transit country for people arriving in Australia through irregular means:

[refugees have] no formal legal status or right to work ... They face the daily prospect of being arrested, detained in squalid conditions, and tortured and otherwise ill-treated, including by caning. They face the constant fear of being forced to return to a country where they may be stripped of their rights or even killed. (Amnesty International 2010: 3; see also chapter 9 in this volume)

These conditions also give people little option but to continue on to Australia to seek asylum. 
It is clear that the majority of such people who seek asylum in Australia are found to be legitimate refugees. According to 2011 figures collected by the Australian department of immigration and citizenship, for example, 'during the Rudd Government approximately 9o-95 percent of assessments completed on Christmas Island resulted in protection visas being granted' (Phillips 2011: 8). Thus a focus on such 'push' factors in the political and media discourse could go some way towards providing government leaders with the courage to initiate policy developments that adhere to international human rights obligations. As noted by Edwards and Ferstman (2010), a focus on security language labels the subjects of the security discourse as threats to security rather than victims of insecurity. Such a securitised approach prevents the broader Australian public from identifying with the plight of asylum seekers. The impact of public identification and sympathy with the humanity of particular refugees is illustrated starkly by the popular public campaign in 1999 that resulted in Australia offering temporary safe haven to 4,000 Kosovars displaced in the break-up of the former Yugoslavia.

\section{New directions}

Up until the middle of 2012, there were signs of new directions being set, both preceding and coinciding with the increased focus on a RCF, and particularly following the new Labor government taking office in November 2007. In 2008, TPVs were abolished, the Pacific Solution abandoned, and the new Labor government introduced its Key Immigration Detention Values. The changes were not enshrined in legislation, however, resulting in accusations that Labor was not adhering to its own values as it continued to detain children, for example. Moreover, in the first plank of the 'values', mandatory detention is embedded as a fundamental component of border control, reinforcing the bipartisan approach to this provision.

Because boat arrival numbers remained low as they did in the final years of the previous Coalition government, the Labor government appeared to have modified its stance. When numbers of arrivals in Australian waters began to increase, the political hyperbole resulted in the opening of the Christmas Island maximum-security detention centre in 2008, which had been built by the Coalition government; the new Labor government, therefore, reneged on its promise in opposition that it would not allow the detention centre to be opened. The expansion of detention on Christmas Island was followed by a succession of new or re-opened detention centres in other parts of Australia. 
From late 2011, when it became clear that the detention facilities on Christmas Island were becoming overcrowded, that mental health issues and protests were increasing in severity, and that Christmas Islanders were becoming increasingly vocal in their opposition to the detention industry on their island, particularly following fires and escapes, the federal government looked for new measures. One positive measure that emerged was the release of people from detention in a timely manner so that they could live in the community, either in community detention or on bridging visas, until the outcome of their claims was finalised. Not only is this more humane, it is also financially more viable. However, the manner of implementation has been slow and somewhat chaotic, with an array of sub-contracting arrangements with the non-governmental sector for housing, services and income support, and difficulties in attracting staff to deal with vulnerable people. Alongside changes to domestic policy and practice, a broader policy paradigm is working, albeit slowly, towards regional cooperation. However, its progress was set back in August 2012 when legislation was introduced to allow newly arriving asylum seekers to be sent to Nauru and to Manus Island in Papua New Guinea (see chapter 9 in this volume). Before discussing the prospects for a regional framework, we discuss Australia's preference for bilateral approaches, past and present, which will need to be rethought if regional cooperation is to take effect.

\section{Bilateral offshore negotiations}

Wealthy Western nations that are signatories to the Refugee Convention extend immigration detention beyond their borders in order to restrict entry by asylum seekers into their own territories (Nethery, Rafferty-Brown \& Taylor 2013), and this has been a focal point of Australian policies intended to deter asylum seekers. The Pacific Solution of the recent past, which involved detention in Papua New Guinea and Nauru, was not an equal partnership with those two countries. Rather, it repositioned Australia in a neo-colonial relationship in which it exercised power through a distortion of foreign aid agendas over Pacific nations considered ripe for exploitation. In creating the Pacific Solution and excising so many islands from its territory, Australia engaged in a process described by Alison Mountz as pushing further away and nearly erasing borders (2010). When these processes are combined with detention in remote parts of the sovereign territory, a powerful geography of exclusion is created. The colonial project, in many and varying guises, represents a range of means for the exploitation of less 
powerful and more vulnerable nations and the economic, governance and imposition of Western worldviews. The location of detention facilities in economically poorer countries is further evidence of colonial entrenchment in dictating 'development': Australia was offering economic rewards in exchange for the location of detention facilities in countries bankrupted through colonialism and its aftermath (Fiske \& Briskman 2009).

Although the Australian Labor government committed itself to ending offshore detention when it came to power in late 2007, once the boats started arriving again, hasty moves were made to revert to offshore options, with the government and the opposition vying to devise offshore alternatives. In response to a rash of alarmist headlines concerning the increase in numbers of boats arriving and the political capital the opposition Coalition parties made of the headlines, Australia tried unsuccessfully in 2011 to convince other countries, such as East Timor and Papua New Guinea, to establish regional assessment centres. Either of these would have served Australia's political objective of finding places outside Australia to send people arriving by sea (Taylor 2011a). Later, the 'remedies' proposed by both major parties centred on shifting asylum seekers away from Australia: the Labor government proposed a people swap with Malaysia, and the Coalition opposition proposed a processing centre on Nauru. In August 2012, bipartisan agreement resulted in Nauru and Papua New Guinea as the chosen locations for processing centres.

Australia still has an agreement with Indonesia to fund immigration detention centres in that country (see chapter 7 in this volume). Policies that essentially exported domestic policy were formulated with Indonesia, which resulted in the detention of asylum seekers in Indonesia from 2000, the introduction of detention policy in 2007 and tougher Indonesian laws in 2011 (Nethery et al. 2013). In the interests of maintaining a good bilateral relationship, Indonesia has assisted Australia in its policy objective of preventing asylum seekers coming to its shores (Nethery et al. 2013). Australian-funded detention centres in Indonesia have been subject to substantial criticism because of their sub-standard conditions.

The Malaysia 'Solution' was controversially formulated in 2011, when the Australian government proposed to send 800 people who arrived in Australia by boat to Malaysia in exchange for taking 4,00o UNHCR refugees from that country. The people removed from Australia would not be permitted to lodge asylum claims in Australia but would be permitted to apply to the UNHCR from Malaysia, which is not a signatory to the Refugee Convention and has been heavily criticised for its treatment of refugees. The Australian prime minister declared that the 800 people 
sent back to Malaysia would 'go to the back of the queue' to apply to enter Australia. The High Court of Australia ruled that the immigration minister could not make a valid declaration in relation to Malaysia as it was not a signatory to the Refugee Convention and that the arrangement between the two governments was not binding (Brennan 2012). Although the Malaysian arrangement was portrayed as a practical implementation of the RCF, the plan disregarded the protection principles of the Framework and therefore did not offer any hope that it would lead to improved refugee protection in the region (Taylor 2011b). Father Frank Brennan, lawyer and academic, pointed out the folly of the policy, which was likely to include children:

If you send a child to the end of a queue which is 100,00o long in Malaysia, the solution is immoral. If you leave the child in Australia, you send a signal to people smugglers that children are exempt from the Malaysian solution and thus you set up a magnet inviting other unaccompanied children to risk the dangerous voyage from Indonesia. The Malaysia Solution then becomes unworkable. (Brennan 2012)

The immigration minister claimed the Malaysia Solution would have prevented deaths at sea. When up to $5^{0}$ arriving asylum seekers drowned at Christmas Island in December 2010, opportunistic politicians purported that it was necessary to get tougher to avoid such tragedies. Their assertive opportunism increased following the deaths of at least seven people in Indonesian waters on their way to Australia. Minister Bowen stated that 'the type of arrangement we negotiated with Malaysia is an effective deterrent' which could prevent 'tragic deaths at sea' (Plea to Liberals 2011). The arrangement failed to acknowledge, however, what would happen to people unable to flee situations of persecution and, once again, put the importance of 'pull' factors rather than 'push' factors at the forefront. A more humane approach to stopping the boats would have been to take more asylum seekers from Indonesia and Malaysia, many who have been in a state of limbo for years (see chapter 7 in this volume). This would be a more effective way of saving lives, as there would be incentives not to attempt the dangerous boat journey to Australia.

On 13 August 2012, the ground again shifted when the prime minister's Expert Panel on Asylum Seekers released its report, having held community consultations over six weeks to provide the federal government with policy options to prevent asylum seekers 'risking their lives on dangerous boat journeys to Australia' (2012: 9). Although the panel 
made 22 recommendations, some of which were intended to advance a regional framework, the government seized upon two recommendations for offshore processing on Nauru and Papua New Guinea, described as a 'circuit breaker'. A controversial 'no advantage' principle was applied whereby asylum seekers would gain no benefit from seeking protection other than through established mechanisms. The Refugee Council of Australia added its voice to the criticisms, arguing that offshore processing could have a damaging impact on prospects for enhanced regional cooperation on refugee protection (2012).

\section{The quest for regional cooperation}

Menadue, Keski-Nummiand and Gauthier present compelling arguments for the establishment of a regional framework (2011: 21). In looking at the region closest to Australia, they point out that in Malaysia there are 212,856 people of concern to the UNHCR, including an estimated 81,516 refugees and people in refugee-like situations; in Thailand, there are 649,430 people of concern to the UNHCR, including 147,019 Burmese in camps along the Thai Burma border; and in Bangladesh, there are 229,253 people of concern to the UNHCR, including some 29,00o Burmese Rohingya registered with the UNHCR and a further 200,000 unregistered people living in the country. In presenting these figures, they argue that no single country can be reasonably expected to manage population movements. They point out that a cooperative approach is not new, referring to the 1989 Comprehensive Plan of Action which addressed the question of Indo-Chinese refugees. Now, however, it is countries such as Malaysia, Thailand and Indonesia who are hosting the bulk of new asylum populations.

Through the RCF, Australia is now looking more outwardly to the region to see how the perceived problem of asylum-seeker flows can be managed holistically. Previously, as we have seen, Australia has put considerably more effort into border control cooperation than refugee protection cooperation (Taylor 2008). In 2002, the Bali Process was established which, although initially mainly concerned with people smuggling and trafficking, has begun to recognise the humanitarian aspects of the movement of people. In March 2011, at the fourth Regional Ministerial Conference on People Smuggling, Trafficking in Persons and Related Transnational Crime, it was agreed that 'an inclusive but non-binding Regional Cooperation Framework (RCF) would provide a more effective way for interested parties to cooper- 
ate to reduce irregular movement through the region'. The following core principles underpin the RCF:

1 Irregular movement facilitated by people smuggling syndicates should be eliminated, and states should promote and support opportunities for orderly migration;

2 Where appropriate and possible, asylum seekers should have access to consistent assessment processes and assessment arrangements, which might include a centre or centres, taking into account any existing sub-regional arrangements;

3 Persons found to be refugees under those assessment processes should be provided with a durable solution, including voluntary repatriation, settlement within and outside the region and, where appropriate, possible 'in-country solutions';

4 Persons found not to be in need of protection should be returned, preferably on a voluntary basis, to their countries of origin, in safety and dignity. Returns should be sustainable, and states should look to maximise opportunities for greater cooperation; and

5 People smuggling enterprises should be targeted through border security arrangements, law enforcement activities and disincentives for human trafficking and smuggling. (Bali Process 2011)

In advocating an RCF, the Australian immigration minister used similar arguments about deaths at sea that were used for promoting the Malaysian plan:

Australia, like many other countries, continues to receive large numbers of irregular arrivals. Many of these people are risking their lives and those of their families by using the services of people smugglers. The dangerous nature of maritime people smuggling ventures was again tragically apparent last December when, in heavy seas, a boat was lost against the rocks at Christmas Island resulting in at least 30 people losing their lives. (Bowen 2011)

Like national attempts at stemming asylum-seeker flows, the Bali process is precarious unless it is a truly regional process with protection at its heart rather than the focus on the smuggling trade. Menadue et al. insist that regional approaches to protection must be backed up by concrete action, particularly by Australia, 'which is often viewed as a fair-weather friend; quick to ask but slow to give' (2011: 22). Taylor sees a positive move forward in the creation of a Regional Support Office to develop the RCF, together with 
the recommendation for a working group (2011b). Although initial project proposals from Australia have had little to do with refugee protection, if the UNHCR can 'nudge the Regional Support Office towards projects designed to put the refugee protection elements of the RCF into operation, then the region may yet start moving in the right direction' (Taylor 2011b).

Although the Expert Panel's recommendations on a regional framework have not yet been acted on by the government, it did suggest a suite of measures to enhance its formation, including: consolidation of the RCF agreed to through the Bali Process; engagement with governments, NGOs and civil society groups on capacity building; increased funding for the UNHCR for the management and processing of asylum seekers across the region; and the introduction of effective mechanisms for oversight and monitoring of regional processes (Expert Panel on Asylum Seekers 2012). Among concerns raised in response to the Panel's report are the lack of progress on the implementation of the RCF, the lack of detail on regional processing arrangements and inadequate consideration of international obligations (Refugee Council of Australia 2012).

\section{Conclusion}

Australia, despite being a signatory to the Refugee Convention and a wellresourced Western nation, clearly abrogates its human rights obligations. Its obsession with its borders is puzzling, given that the flow of asylum-seeking boat people to Australia is, comparatively speaking, minimal. The fallout is that Australia's reputation as a nation that respects human rights and as a good neighbor is nullified because it places its own national interests above a moral imperative to create a just approach towards asylum seekers and an equitable relationship with nations in the region. Given Australia's wealth, space and commitment to refugee protection through UN instruments, it has the potential to become a role model for countries that do not at this stage integrate refugees into their own populations. Although Nauru and Papua New Guinea have signed up to new bilateral agreements, there is evidence of wariness, with both countries insisting that asylum seekers remain on the islands for as short a time as possible before they are resettled or repatriated (Callick 2012).

If Australia was to assume a leadership role in taking on the responsibility of protecting asylum seekers, it could sustain the RCF project, which is likely to take a number of years to become operational, if it is not set back by the recent offshore developments. In reality, no matter how tough Australia 
is about its borders and how many nations Australia persuades to take on a responsibility that it should own, asylum seekers will continue to take risks in their quest for safety and protection. As we complete our chapter in September 2013, a conservative Coalition government has just taken power and has signaled even tougher approaches to asylum seeker boat arrivals than the previous Labor government. The Coalition's stance on an RCF has not yet been announced. 



\title{
$9 \quad$ Courting disaster?
}

Regional agreements for 'protection elsewhere' and the courts

\author{
Penelope Mathew
}

\section{Introduction}

Unauthorised migration (migration that does not comply with national immigration laws) occurs for a variety of reasons, some of which are recognised and protected by international law, while others are not. Some migrants may arrive with a lawful status (a visa or entry permit, for example) but lose it subsequently. This commonly occurs in Australia, as visitors overstay their visas. Others will be unable to secure entry under domestic law for their desired purposes. Impoverished Mexicans desperate for employment in the United States may decide to enter the United States clandestinely, for example.

The focus of this chapter is refugees and people seeking protection as refugees ('asylum seekers'). Refugees are people who must be granted protection from human rights violations at home; they too, however, will find it difficult to migrate in conformity with national immigration laws, because a person is only a refugee once they have crossed an international border and because many countries deliberately shield themselves from refugee flows. Consequently, people seeking legal status as refugees frequently have to resort to people smugglers in order to get the protection they need. They are then unfairly labelled as illegal or criminal in public discourse, along with the people smugglers.

This chapter examines some regional and bilateral agreements that attempt to ensure that refugees and asylum seekers stay in the country to which they first flee or are returned to that country. One of the problems with these regional agreements is that refugee rights are neither universally accepted nor universally implemented and, as a consequence, these agreements pose risks for refugee rights that invite litigation. The important role of the courts in protecting refugee rights from the potentially corrosive effects of these agreements will be explored.

The chapter develops as follows. First, the phenomenon of regionalism in refugee protection is briefly examined. Then the agreements subjected to judicial scrutiny in a number of specific court cases are discussed. The 
chapter turns next to look at two court decisions that examine the extent to which participation in relevant treaties has been accepted as a sufficient guarantee of refugee rights, particularly the cardinal prohibition on torture and related ill treatment. The chapter then examines two further decisions that considered whether rights beyond the prohibition on torture and return to a place of persecution must be guaranteed for refugees. Some observations about the role of the courts and their impact on the politics of regionalism conclude the chapter.

\section{Regionalism in refugee protection}

The first 'universal' refugee treaty - the $195^{1}$ Convention Relating to the Status of Refugees (Refugee Convention) ${ }^{2}$ - began life as a response to a regional refugee problem. Its definition of a refugee was designed to protect those displaced as a result of World War II and its aftermath. A person was only a refugee because of events occurring before 1 January 1951, and states that were party to the convention had the option of further limiting their obligations to refugees displaced as a result of events in Europe. The definition - which encompassed people who were outside their countries of origin owing to a well-founded fear of being persecuted for reasons of race, religion, nationality, membership of a particular social group or political opinion - was backward-looking. As a result, regional agreements with broader definitions of a refugee have been adopted in Africa and the Americas in order to respond to the experiences of refugees in those regions. ${ }^{3}$

The Refugee Convention did not, however, seek to limit the parties responsible for sheltering refugees to European countries - quite the contrary. The movement of refugees is one aspect of migration that requires a global response. Individuals flee for their lives from many regions of the world, effectively asserting their right to seek asylum under Article 14 of the Universal Declaration of Human Rights. ${ }^{4}$ In 1967 , the Protocol relating to the

2 Convention relating to the Status of Refugees, opened for signature 28 July 1951, 189 UNTS 150 (entered into force 22 April 1954).

3 Organization of African Unity Convention Governing the Specific Aspects of Refugee Problems in Africa, opened for signature 10 September 1969, 1001 UNTS 45 (entered into force 20 June 1974) (African Union Refugee Convention); Cartagena Declaration on Refugees (adopted by the Colloquium on the International Protection of Refugees in Central America, Mexico and Panama, 22 November 1984) in 'Annual Report of the Inter-American Commission on Human Rights' (1984-85) OAS Doc OEA. /Ser.L/V/II.66/doc.10, rev 1, 190-3.

4 GA Res 217A (III), UN GAOR, 3rd sess, 183rd plen mtg, UN Doc A/810 (10 December 1948). 
Status of Refugees (Refugee Protocol) ${ }^{5}$ lifted the temporal and geographic restrictions on the definition, ensuring that the definition in the Convention applied to refugees from anywhere and into the future. If refugees are to be fairly treated the world over, it is important to have a universal definition of refugee-hood that is implemented uniformly and for refugees' rights to be observed everywhere. However, while the Refugee Convention now protects refugees from every country, the Convention and Protocol have not yet attracted universal support from countries. Many Asian countries and Middle Eastern countries are not party to the Convention.

The coverage of the Refugee Convention might be described as incomplete in other ways, too. Nowhere does it say that any particular country is bound to guarantee entry to its territory, nor does the Convention contain any legally binding obligation to share responsibility for refugees. Many countries have adopted mechanisms, such as carrier sanctions (penalties on airlines, for example) and visa requirements for persons from refugeegenerating countries, to prevent the arrival of asylum seekers in their territories in the hope of avoiding all responsibility for them. Some countries have also adopted regional or bilateral agreements where the government in one country will return refugees to another country.

These agreements might be justified as long as refugees are protected somewhere; then there would be no problem with returning or sending refugees to another country. This is sometimes described as 'protection elsewhere' (Foster 2007: 230-237). 'Protection elsewhere' does not have a firm textual footing in the Refugee Convention, which says very little about sending refugees and asylum seekers elsewhere. The cardinal obligation imposed by the treaty is the obligation of non-refoulement - namely the obligation not to return a refugee to a place of persecution (Article 33). The only references to a requirement that refugees or asylum seekers go to safe third countries are in Articles 31 and 32 . Article 32 prohibits the expulsion of a 'lawfully present' refugee except on grounds of national security or public order, while Article 31 is a safeguard against unnecessary restrictions on the movement of unauthorised asylum seekers, allowing restrictions to be imposed only until his/her status is regularised or the person gains admission to another country. In each case, the individual concerned is to be given 'a reasonable period' to obtain admission to another country.

More importantly, it is evident that refugees are not always protected in the places to which they are sent under these agreements. In addition,

5 Protocol relating to the Status of Refugees, opened for signature 31 January 1967, 606 UNTS 267 (entered into force 4 October 1967). 
these agreements often reflect power imbalances in which richer states return refugees to poorer states, which may be less capable of providing for refugees, thereby operating as a containment device. Matthew Gibney describes this phenomenon as 'engineered regionalism' (2007:58) because the states of the Global North intervene to prevent the globalisation of asylum.

\section{Engineered regionalism in Europe and the Asia-Pacific}

One example of a regional agreement is the Dublin Regulation. ${ }^{6}$ Pursuant to this agreement, the member states of the European Union (EU) agreed that responsibility generally rests with the first European state to which an unauthorised migrant from a non-EU country - that is, one who arrives without a visa or other document as required by national immigration law - gains physical access. ${ }^{7}$ The Dublin Regulation reflects an internal division between heartland and periphery, haves and have-nots, providers and the deprived. After the collapse of the Berlin Wall, Germany, along with other similarly situated countries, pushed for arrangements to minimise the potential pull factor of strong economies, which were perceived to result in abuse of the asylum process by economic migrants (Gibney 2004: 101-102). The intra-European arrangements do not share responsibility on the basis of capacity, but rather leave the 'burden'8 ${ }^{\text {' }}$ where it lies. ${ }^{9}$

It is assumed that it is safe for EU member states to rely on each other in this manner, because the EU has supposedly effectively harmonised the treatment of refugees and asylum seekers throughout the region and is thought to be a safe place for third-country nationals. In addition to the Dublin Regulation, there are three key EU instruments governing the

6 The version of the regulation relevant to the discussion of the case law in this chapter is the 'Dublin II Regulation': Council Regulation (EC) No. 343/2003 of 18 February 2003 establishing the criteria and mechanisms for determining the member state responsible for examining an asylum application lodged in one of the member states by a third-country national [2003] OJ L 50/1 (Dublin II Regulation).

7 Dublin II Regulation, article 10.

8 It has long been recognised that it is derogatory to speak of refugees as a burden, and that the term responsibility is preferable and also more descriptive of the ways in which all states can contribute to solutions for refugees, as responsibility-sharing can occur through financial support as well as the physical accommodation of people.

9 On the question of why capacity should be the criterion, see Kritzman-Amir (2009). 
treatment of refugees and asylum seekers - the 'Qualification Directive', ${ }^{10}$ the "Reception Directive" ${ }^{11}$ and the "Procedures Directive"12 - that seek to harmonise the application of the Refugee Convention in EU states. However, Greece, which forms part of the southern gateway to Europe, has not protected refugees, resulting in an important decision from the European Court of Human Rights - M.S.S. v Belgium and Greece ${ }^{13}$ - as well as one from the Court of Justice of the European Union: N.S. $v$ Secretary of State for the Home Department and M.E. and others v Refugee Applications Commissioner, Minister for Justice, Equality and Law Reform. ${ }^{14}$

The Dublin Regulation also permits EU states to send asylum seekers to countries outside the EU. Not surprisingly, states at the gateway to Europe have sought to deflect refugees by sending them to countries outside the region. Italy negotiated an agreement with Libya whereby migrants and asylum seekers embarking on sea journeys to Italy were intercepted and returned to Libya. ${ }^{15}$ Libya does not have a domestic asylum procedure. Irregular migrants in Libya faced appalling conditions of detention as well as precarious living conditions within the Libyan community. There was also the ever-present possibility of being returned to their countries of origin (such as Eritrea, Somalia and Nigeria). The European Court of Human Rights delivered another strong decision concerning this agreement in Hirsi

10 Directive 2011/95/EU of the European Parliament and of the Council of 13 December 2011 on standards for the qualification of third-country nationals or stateless persons as beneficiaries of international protection, for a uniform status for refugees or for persons eligible for subsidiary protection, and for the content of the protection granted [2011] OJ L 337/9 (Recast Qualification Directive).

11 Directive 2013/33/EU of the European Parliament and of the Council of 26 June 2013 laying down standards for the reception of applicants for international protection [2013] OJ L 180/96 (Recast Reception Directive).

12 Directive 2013/32/EU of the European Parliament and of the Council of $26 \mathrm{June} 2013$ on common procedures for granting and withdrawing international protection [2013] OJ L 180/6o (Recast Procedures Directive).

13 European Court of Human Rights, Grand Chamber, Application No 30696/o9, 21 January 2011.

14 Court of Justice of the European Union, C-411/10 and C-493/10, 21 December 2011 (N.S. and M.E.).

15 See the description of the bilateral cooperation agreement signed in Tripoli on 29 December 2007 in Hirsi Jamaa and Others $v$ Italy (ECtHR, Grand Chamber, Application No 27765/o9, 23 February 2012)[5] (Hirsiv Italy). 
vItaly. ${ }^{16}$ A new version of the Dublin Regulation (the Dublin III Regulation) reflects some of the lessons learned from this case law. ${ }^{17}$

Drawing in part on the European practice, Australia has adopted its own version of 'protection elsewhere'. Operating in the Asia-Pacific region in which most states are not party to the Refugee Convention and/or Protocol, unlike the EU, Australia has had to offer incentives to other countries in the region in order to send or return asylum seekers to them. For example, during the years of the Liberal-National Howard government, Australia contracted Nauru and Papua New Guinea to house, or rather detain, asylum seekers while their claims to refugee status were heard. In addition to paying for the detention centres, development aid was offered as an incentive (see Fry 2002). These arrangements, known as the 'Pacific Solution', concluded in 2008 when the Labor prime minister closed the overseas detention centres. Following an increase in boat arrivals, however, the opposition insisted that Labor government policies were to blame and suggested reviving the Pacific Solution. Eventually, the government (led by Julia Gillard) capitulated, and asylum seekers are again being detained in Nauru and Papua New Guinea. However, it is questionable whether the new version of the Pacific Solution will have the impact it was perceived to have in the first iteration, when there was a marked drop in boat arrivals (see chapter 8 this volume). ${ }^{18}$ Many of the refugees sent to Nauru and Papua New Guinea had to be resettled in Australia, and the arrangements were very costly, both financially and in terms of the mental health of the refugees and asylum seekers concerned (Bem et al. 2007).

Prior to its decision to return to the Pacific Solution, the Labor government proposed as an alternative that 800 asylum seekers be sent to Malaysia in exchange for resettling in Australia 4,000 refugees recognised by the United Nations High Commissioner for Refugees in Malaysia. ${ }^{19}$ This resulted in a challenge before the Australian High Court in the cases of Plaintiff M7o/2011 v Minister for Immigration and Citizenship; Plaintiff Mio6 of 2011

16 Hirsiv Italy (ECtHR, Grand Chamber, Application No 27765/09, 23 February 2012).

17 Regulation (EU) No 604/2103 of the European Parliament and of the Council of 26 June 2013 establishing the criteria and mechanisms for determining the Member State responsible for examining an application for international protection lodged in one of the Member States by a third-country national or a stateless person [2013] OJ L 180/31 (Dublin III Regulation).

18 For the statistics on boat arrivals, see Phillips \& Spinks (2012).

19 Australian minister for immigration and citizenship, 'Arrangement between the Government of Australia and the Government of Malaysia on Transfer and Resettlement', signed 25July 2011, www.minister.immi.gov.au/media/media-releases/_pdf/20110725-arrangement-malaysiaaust.pdf, 3-4 (Australia-Malaysia Agreement). 
$v$ Minister for Immigration and Citizenship $\left({ }^{\prime} M 70^{\prime}\right) .{ }^{20}$ The decision in these cases, which required that any country in which offshore processing was undertaken have legal protections in place for refugees and asylum seekers as a matter of international or domestic law, ${ }^{21}$ was circumvented with the passage of the Migration Legislation Amendment (Regional Processing and Other Measures) Act 2012 (Commonwealth of Australia). This legislation implements one recommendation by an expert panel convened by the government following protracted, acrimonious debate over unauthorized boat arrivals, to

provide advice and recommendations to the Government on policy options available, and in its considered opinion, the efficacy of such options, to prevent asylum-seekers risking their lives on dangerous boat journeys to Australia. (Expert Panel on Asylum Seekers 2012: 9)

Although $M 70$ was overturned, the decision has some important things to say about the way in which international refugee law is to be applied. Its overturn through legislation also raises serious questions about the role of law in refugee protection.

\section{See no evil: Does participation in international treaties justify an assumption of compliance?}

One difference between the EU arrangements and the Australian bilateral agreements is that EU countries seek to rely on the international legal commitments of other states in order to comply with their own obligations, while Australia has often sought to rely on countries that have not accepted similar international legal obligations. Indeed, the Migration Act 1958 (Commonwealth of Australia) has almost been stripped of any references to human rights protection in response to the High Court's decision that law is a sina qua non of refugee protection. There are problems with each strategy. Treaty participation is a necessary but not sufficient requirement for refugee protection.

20 Plaintiff M70/2011 v Minister for Immigration and Citizenship; PlaintiffMro6 of 2011 vinister for Immigration and Citizenship (2011) 244 CLR 144 (M70).

$21 M 70$ (2011) 244 CLR 144 [61]-[65] (French CJ); [117]-[120] (Gummow, Hayne, Crennan and Bell JJ); [240]-[244] (Kiefel J). 
The question of whether the participation of supposedly safe third countries in relevant international and regional treaties is sufficient for EU states to acquit their own obligations was tested in M.S.S. $v$ Belgium and Greece. ${ }^{22}$ In this case, the Grand Chamber of the European Court of Human Rights examined the situation of asylum seekers returned from Belgium to Greece under the Dublin Regulation. The Court undertook a detailed examination of material from non-governmental organisations concerning the situation in Greece and held that Belgium knew or ought to have known that Greece was not meeting its international commitments. ${ }^{23}$ The Court held, inter alia, that both Greece and Belgium were liable for violations of Article 3 of the European Convention on Human Rights (ECHR), ${ }^{24}$ which prohibits torture or inhuman or degrading treatment or punishment, as a result of the substandard refugee status determination procedure and conditions of detention in which many asylum seekers were held in Greece and the destitution they were subjected to when living in the Greek community. The case is significant because it confirms that in certain circumstances, economic deprivation may amount to a violation of Article 3 and that EU states cannot blindly rely on the presumption of safety that underpins the EU instruments governing asylum. This offers a significant safety net for the protection of refugees and asylum seekers' rights.

In Hirsi v Italy, ${ }^{25}$ the Court was forced to venture further afield and consider whether Italy could return asylum seekers to Libya under a bilateral agreement that permitted the interception of asylum seekers at sea. Italy's justification of its action included two major points. ${ }^{26}$ First, Libya could be assumed to live up to its obligations ${ }^{27}$ - in this case, not the Refuge Convention as Libya is not a party, but the African Union Refugee Convention, ${ }^{28}$ the International Covenant on Civil and Political Rights ${ }^{29}$ and the Convention

22 M.S.S. v Belgium and Greece (ECtHR, Grand Chamber, App No 30696/o9, 21 January 2011).

23 M.S.S. v Belgium and Greece (ECtHR, Grand Chamber, App No 30696/og, 21 January 2011) [348].

24 European Convention on Human Rights, ETS 5.

25 Hirsiv Italy (ECtHR, Grand Chamber, Application No 27765/o9, 23 February 2012).

26 There were also a number of smaller arguments, such as whether the applicants had asked for protection and whether the lawyers had proper power of attorney to act for the applicants. 27 Hirsiv Italy (ECtHR, Grand Chamber, Application No 27765/o9, 23 February 2012) [97]-[98].

28 Organization of African Unity Convention Governing the Specific Aspects of Refugee Problems in Africa, opened for signature 10 September 1969, 1001 UNTS 45 (entered into force 20 June 1974). 29 International Covenant on Civil and Political Rights, opened for signature 16 December 1966, 999 UNTS 171 (entered into force 23 March 1976). 
against Torture and other Cruel, Inhuman or Degrading Treatment or Punishment ${ }^{30}$ - despite all the evidence to the contrary.

Second, Italy argued it was not exercising 'jurisdiction' over the asylum seekers during the interception operations but merely a 'rescue'. ${ }^{31}$ Consequently, Italy took the view that its own human rights obligations, including those under the ECHR, did not accompany its border personnel onto the High Seas. Ironically, therefore, Italy sought to use its law enforcement personnel to avoid the law.

As in M.S.S. $v$ Belgium and Greece, the Grand Chamber found that Italy must have known or should have known that the interception programme would result in the violation of its obligations. ${ }^{32}$ The Court also emphatically rejected the characterisation of the High Seas as

an area outside the law where individuals are covered by no legal system capable of affording them enjoyment of the rights and guarantees protected by the Convention which the States have undertaken to secure to everyone within their jurisdiction..$^{33}$

The Court found, unanimously, that Italy was enforcing its law by exercising its jurisdiction over the migrants and asylum seekers and controlling its border. Consequently, Italy had violated the prohibition on collective expulsion contained in the fourth protocol to the ECHR, along with Article 3 of the ECHR. ${ }^{34}$

This is a new development. It was quite possible that the Court might have distinguished between non-refoulement and expulsion. With the exception of the ruling to the contrary by the US Supreme Court in Sale $v$ Haitian Centers Council, ${ }^{35}$ it has long been accepted that non-refoulement is a broad term encompassing repulsion from territory and extra-territorial in scope (Goodwin-Gill \& McAdam 2007: 246-250; Hathaway 2005: 163, 336-337). By contrast, expulsion connotes pushing out of territory and therefore implies entry to it. The Court's case law had previously only considered expulsions from within state territory.

30 Convention against Torture and Other Cruel, Inhuman or Degrading Treatment or Punishment, opened for signature 10 December 1984, 1465 UNTS 85 (entered into force 26 June 1987).

31 Hirsiv Italy (ECtHR, Grand Chamber, Application No 27765/o9, 23 February 2012) [65].

32 Hirsiv Italy [131] \& [156].

33 Hirsiv Italy [178].

34 Hirsi $v$ Italy [182] and dispositif, points 6, 7, 8 \& 9 .

35 Salev Haitian Centers Council 509 US 155 (1993). 
In both M.S.S. $v$ Belgium and Greece and Hirsi v Italy, the Court did not permit countries to operate on the basis of mutual confidence by a cursory look at whether the supposedly safe third country concerned participates in relevant international or regional treaties. Nor did it permit European countries to avoid their obligations by acting extraterritorially. Instead, the Court looked at the practice on the ground in the purported safe third countries. Consequently, neither Greece nor Libya's treatment of migrants and asylum seekers was seen to conform to relevant obligations, while Italy's obligations followed it out onto the High Seas.

\section{Beyond the prohibitions on torture and refoulement to persecution}

The Court's focus in M.S.S. v Belgium and Greece and Hirsiv Italy was on the prohibition of refoulement to a place of torture or related ill treatment. It is well established that the prohibition on torture and related ill treatment includes a non-refoulement norm. Importantly, though, notwithstanding the Court's evident willingness to include certain forms of economic deprivation within that prohibition, there is a threshold of severity that must be satisfied which may not encompass all human rights violations. It may be questionable whether denial of any and every right, even on the discriminatory basis that the persons concerned are refugees or asylum seekers, meets the threshold of severity. Denial of the empowerment right to an education, particularly primary and secondary education, may well be regarded as degrading treatment even if it is not as immediately severe as the destitution suffered in M.S.S. v Belgium and Greece, but how would courts respond if governments denied refugees the right to join trade unions? Frequently, the denial of refugee rights is cumulative, but it is possible to think of hypotheticals in which only particular rights are targeted, which, on their own, might not cross the threshold of inhuman or degrading treatment or punishment.

There is also controversy as to the list of rights to which a non-refoulement obligation attaches. Non-refoulement is essentially a device to avoid complicity in harm ${ }^{36}$ by preventing return while a person remains within state

$3^{6}$ As the framers of the Refugee Convention put it, " $\mathrm{t}$ ] he turning back of a refugee to the frontiers of a country where his life or freedom would be threatened on account of his race, religion, nationality or political opinion would be tantamount to delivering him into the hands of his persecutors.' Report of the Ad Hoc Committee on Statelessness and Related Problems, Lake 
jurisdiction. However, only certain rights - those apparently causing irreparable harm or, in the case of many ECHR rights, 'flagrant denials' of the right - are accepted as carrying non-refoulement obligations. ${ }^{37}$

With respect to other rights, the situation is generally different. Although it has been argued that the obligation of non-refoulement may extend to many human rights on the basis of a 'complicity principle' whereby any state that sends a person back to a place where their rights would be violated is also held responsible for the violations (Legomsky 2003), the extension of clear obligations of non-refoulement has in fact happened incrementally. Explicit treaty norms have been adopted one by one (the Refugee Convention was followed by Article 3 of the Convention against Torture, for example) and judicial precedents implying non-refoulement norms into human rights provisions (such as the European Court of Human Right's decision in Soering $v$ United Kingdom $)^{38}$ have accumulated slowly.

The argument that every human right carries a non-refoulement obligation would have a significant impact on state sovereignty over immigration and cannot, unfortunately, be readily accepted (Battjes 2009). Generally, the sending state does not incur responsibility through the mere act of sending someone away. Absent some more active participation - for example, a continued exercise of jurisdiction in the sense of effective control over the person, ${ }^{39}$ or an act of aiding and abetting a human rights violation ${ }^{40}-$ it is the responsibility of the receiving state to comply with human rights. Therefore, a different explanation as to why international law requires respect for refugee rights beyond the fundamental protection from return to a place of persecution, as a prerequisite for the treatment of a country as a safe third country, needs to be supplied. Without such justification, governments may take an extreme and troubling approach to the protection of refugees, which could leave refugees without any rights protection other

Success, New York, UN ESCOR, UN Doc E/1618; UN Doc E/AC.35/5 (16 January-16 February 1950) annex II ('Comments on the draft convention') 61.

37 For criticism of the thresholds, see Battjes (2009).

38 Soering v United Kingdom (1989) 161 Eur Court HR (ser A).

39 Human Rights Committee, General Comment No 31: The Nature of the General Legal Obligation Imposed on States Parties to the Covenant, 8othsess, UN Doc CCPR/C/21/Rev.1/Add. 13 (29 March 2004) [10].

40 See Article 16 of the International Law Commission's Draft Articles on Responsibility of States for Internationally Wrongful Acts, in Report of the International Law Commission on the Work of Its Fifty-third Session, UN GAOR, 56 th sess, Supp. No 10, UN Doc A/56/10 (2001). 
than the most basic protection from active refoulement, which is exactly the position adopted by the Australian Government Solicitor in $M_{70 .}{ }^{41}$

Over the years, the UNHCR and experts have adopted a reading of the Refugee Convention that seeks to shore up rather than diminish refugee protection. The executive committee of the UNHCR programme has recognised in several conclusions ('executive committee conclusions' or 'ExCom conclusions') that any country to which a refugee is sent must 'treat the asylum-seeker (asylum-seekers) in accordance with accepted international standards, ... ensure effective protection against refoulement, and ... provide the asylum-seeker (asylum-seekers) with the possibility to seek and enjoy asylum'. ${ }^{42}$ An expert roundtable convened in Lisbon by the UNHCR came to a similar position. ${ }^{43}$ More recently, the Michigan Guidelines on Protection Elsewhere (adopted by a group of experts and senior Michigan Law School students) stated that refugees should be entitled to all the rights guaranteed in Articles 2-34 of the Refugee Convention in any place to which they are sent (Hathaway 2007: 215). In this section of the chapter, two cases in which courts have grappled with this issue are examined: the Australian High Court's decision in $M_{70^{44}}$ and the decision by the Court of Justice of the European Union (CJEU) in N.S. and M.E. ${ }^{45}$

\section{Swapping unauthorised asylum seekers for recognised refugees and the High Court's decision on 'protection elsewhere'}

The Australian government's agreement with Malaysia reflected Australia's consternation over unauthorised asylum seekers arriving by boat as opposed to refugees screened in and resettled from countries of first asylum. Under this arrangement, Australia agreed that it would resettle 4,000 persons from Malaysia recognised by UNHCR as refugees in exchange for Malaysia accepting 800 asylum seekers who had arrived in Australia by

\footnotetext{
41 See the exchange between the Solicitor-General and Justice Gummow concerning Professor Hathaway's position: Transcript of Proceedings, Plaintiff M7o/2011 v Minister for Immigration and Citizenship; PlaintiffMro6 of $2011 v$ Minister for Immigration and Citizenship [2011] HCATrans 224 (23 August 2011).

42 This formulation in particular is found in UNHCR Executive Committee, Conclusion No 85 (XLIX), 'International Protection' (1998)[aa].

43 UNHCR, "Summary Conclusions on the Concept of "Effective Protection" in the Context of Secondary Movements of Refugees and Asylum-Seekers' (Lisbon Expert Roundtable, 9-10 December 2002)' (2003) [15.b].

44 M7o (2011) 244 CLR 144.

45 N.S. and M.E. (CJEU, C-411/10 and C-493/10, 21 December 2011).
} 
boat without visas. $M 70^{46}$ involved two conjoined cases concerning asylum seekers due to be returned under the so-called Malaysia swap - one adult and one unaccompanied minor.

Malaysia is not a party to the Refugee Convention, the Convention against Torture and Other Cruel, Inhuman or Degrading Treatment or Punishment, or the International Covenant on Civil and Political Rights, although it is a party to the Convention on the Rights of the Child. ${ }^{47}$ Malaysia may be bound by a non-refoulement norm preventing return to a place of persecution as a matter of customary international law, and it is certainly bound by the customary and peremptory or non-derogable prohibition on refoulement to a place of torture ${ }^{48}$ In practice, however, Malaysia treats asylum seekers as illegal immigrants and does not have a domestic procedure for recognition of refugee status.

If it is impermissible to rely on another country's mere membership of a treaty in order to acquit a country's own obligation of non-refoulement, it seems foolhardy to rely on a customary legal rule in circumstances where there is no domestic legal framework implementing the customary rule and/or the practice of the state does not comply with it (Wood \& McAdam 2012: 295). Unfortunately, many countries do not implement their international obligations in the domestic legal arena. The Lisbon Roundtable took the view that a non-party state could only be viewed as safe if it had adopted procedures 'akin' to those which are party to the convention. ${ }^{49}$

The High Court was required to consider whether the Australian minister had validly declared Malaysia to be a safe third country to which the asylum seekers could be sent, under s198A of the Migration Act. At the time of the Court's decision, section $198 \mathrm{~A}(1)$ of the Migration Act permitted the

$46 \quad M 70$ (2011) 244 CLR 144.

47 Convention on the Rights of the Child, opened for signature 20 November 1989, 1577 UNTS 3 (entered into force 2 September 1990).

48 The states parties to the Refugee Convention and Protocol have declared that non-refoulement is customary international law: UNHCR, 'Declaration of States Parties to the 1951 Convention and or Its ${ }_{1967}$ Protocol relating to the Status of Refugees (as adopted at the Ministerial Meeting of States Parties in Geneva Switzerland on 13 December 2001), UN Doc HCR/MMSP/2001/o9' (2002)[4]. Malaysia and some other countries in the Southeast Asian region pushed back boats during the Vietnamese refugee outflow, and they might conceivably argue they are 'persistent objectors' to any norm of customary international law and not bound by it. (This argument is not available in the case of the norm preventing return to a place of torture given its status as jus cogens).

49 UNHCR, 'Summary Conclusions ...' (2003), [15.e.]. 
transfer of asylum seekers to another country where the minister had made a declaration under $\operatorname{sig} 8 \mathrm{~A}(3)$ that the country

i. provides access, for persons seeking asylum, to effective procedures for assessing their need for protection; and

ii. provides protection for persons seeking asylum, pending determination of their refugee status; and

iii. provides protection to persons who are given refugee status, pending their voluntary repatriation to their country of origin or resettlement in another country; and

iv. meets relevant human rights standards in providing that protection ...

Although this provision was used to transfer asylum seekers to Nauru and Papua New Guinea as part of the Howard government's version of the Pacific Solution, and Nauru was not then a party to the Refugee Convention, $M 70^{50}$ was the first time the High Court considered a ministerial declaration of a country as safe under s198A. Consequently, one of the unknowns was the extent to which the declaration was judicially reviewable. The government argued that to comply with the section, the minister must have made an evaluative judgment, in good faith, concerning the criteria in s198A. Further, the government argued that the criteria required the minister to focus on the 'practical reality' or factual situation, which was supposedly evidenced by a Memorandum of Understanding (MOU) between Australia and Malaysia, an MOU that was specifically said to be non-binding. ${ }^{51}$

None of the six majority judges accepted that the minister could rely on what he hoped might occur on the basis of the MOU, which the minister's affidavit revealed as the true basis of his decision. ${ }^{52}$ The minister had made his declaration on the inadequate assessment that Malaysia had made a 'significant conceptual shift in its thinking about how it wanted to treat refugees and asylum-seekers' and had 'begun the process of improving protection offered to such persons'.53 The majority judges agreed that the criteria in s198A subparagraphs (i) to (iii) referred to 'protection', a legal

$50 \quad$ M70 (2011) 244 CLR 144.

$5^{1}$ Australian minister for immigration and citizenship, 'Arrangement ...' signed 25 July 2011, Clause 16.

$5^{2} \quad$ M7o (2011) 244 CLR 144 [58]-[59] (French CJ).

53 Minister for immigration and citizenship and commonwealth of Australia, 'Submissions of the Defendants', Submission in Plaintiff M70/2011 v Minister for Immigration and Citizenship; Plaintiff Mıo6 of $2011 v$ Minister for Immigration and Citizenship, Case No M70/2011; M106/2011, 18 August 2011 [84.3]. 
term of art (i.e. encompassing the scheme of recognised refugee rights in the Convention and the means to protect them), and therefore required the minister to have regard to the legal situation..$^{54}$ The question to be answered was whether Malaysia was bound by international law or its own domestic law to do all the things set out in the section.

This is a relatively easy question for a court to answer. While the content of customary international law presents some difficulties and Australian courts have been wary of it, it is easy for an Australian court to establish whether another country is party to a treaty, and foreign law may be proved as a fact before Australian courts. The majority found that the minister's declaration of Malaysia as a safe country for the purposes of s198A was invalid because Malaysia was not party to the Refugee Convention and had no domestic asylum procedure..$^{55}$ Four majority judges wrote a joint judgment in which they said that the criteria in s198A were meant to be a 'reflex' of Australia's international legal obligations and that any country to which asylum seekers were transferred would offer the same legal protection as Australia. ${ }^{56}$

The Court did not clearly indicate whether it would go beyond the criteria of treaty ratification or proof of domestic legal obligations and review whether or not a declared country implemented these laws in practice. To go beyond the legal situation and examine the facts on the ground is a slightly more difficult task for a domestic court to undertake, but certainly not impossible. It would have required the High Court to undertake the kind of scrutiny exercised by the European Court of Human Rights in M.S.S. $v$ Belgium and Greece, where reports by non-governmental organisations and submissions from the UNHCR were accepted as showing that the human rights situation was substandard in Greece (the UNHCR was not party to the Malaysia agreement, but the regional office in Canberra had accepted the agreement as 'workable', ${ }^{57}$ so it might have been interesting to see what evidence the organisation would have presented). Two judges, Chief Justice French and Justice Kiefel, indicated that $\mathrm{sig} 8 \mathrm{~A}(3)$ required the minister to look at the facts on the ground as well as whether the legal protections were

54 M7o (2011) 244 CLR 144 [61]-[65] (French CJ); [117]-[120] (Gummow, Hayne, Crennan and Bell JJ); [240]-[244] (Kiefel J).

55 M7o (2011) 244 CLR 144 [66] (French CJ); [135]-[136] (Gummow, Hayne, Crennan and Bell JJ); [249]-[254] (Kiefel J).

56 M7o (2011) 244 CLR 144 [118] (Gummow, Hayne, Crennan and Bell JJ).

$57 \quad M 70$ (2011) 244 CLR 144 [25] (French CJ). 
in place.$^{8}$ The majority simply noted that it was not necessary to decide this issue for the purposes of this case. ${ }^{59}$

Another unknown in $M 70$ was exactly what 'human rights' would need to be observed in a third country before the minister could declare it to be safe. The joint majority judgment dealt with this question by saying that,

when s $198 \mathrm{~A}(3)(\mathrm{a})(\mathrm{iii})$ speaks of a country that "provides protection to persons who are given refugee status, pending their voluntary repatriation to their country of origin or resettlement in another country", it refers to provision of protections of all of the kinds which parties to the Refugees Convention ... are bound to provide to such persons. ${ }^{60}$

Protection, in the view of the High Court, means the full scheme of rights protection contained in the Refugee Convention, not just the obligation of non-refoulement.

This scheme of protection is qualified, however. The Refugee Convention makes some rights conditional on refugees securing lawful presence' or 'lawful stay', for example (see Hathaway 2005; Mathew 2012). Very important rights, like the right to work, are conditioned in this way. The joint judgment avoided the controversy as to what rights must be met if the asylum seeker is transferred before they have had their status determined and been granted 'lawful presence' under Australian law, noting that it was unnecessary to decide the issue. ${ }^{61}$ What mattered was that the Refugee Convention contained a scheme of rights beyond non-refoulement and that Australia's legislation required any declared country to act as a reflex of those obligations.

Although the High Court was construing Australian legislation, not the Refugee Convention directly, the legislation was consistent with executive committee conclusions, and the judgment sheds light on what the international legal approach to refugee protection should be. If another country agrees to take the asylum seekers, then it should be required to take full responsibility and to allow the person to acquire the rights due to refugees lawfully present or lawfully staying in that country. Of course, this should

$5^{8}$ M7o (2011) 244 CLR 144 [67] (French CJ); [245] (Kiefel J) suggesting that the minister might consider that the criteria were not met where, despite the law on the books, the human rights of asylum seekers were not protected in practice.

$59 M 70$ (2011) 244 CLR 144 [113]-[114], [124] (Gummow, Hayne, Crennan and Bell JJ).

$60 \quad M 70$ (2011) 244 CLR 144 [119] (Gummow, Hayne, Crennan and Bell JJ).

$61 \quad M 70$ (2011) 244 CLR 144 [117] (Gummow, Hayne, Crennan and Bell JJ). 
mean recognition in domestic law that the persons concerned are lawfully present or staying.

This approach is logical if we are not to empty the Convention of nearly all content, whittling down the bill of rights for refugees to one obligation: the prohibition on physical return to a place of persecution. The absence of a right to enter any state party should not result in the divorce between the obligation of non-refoulement and the rest of the bill of rights. Although the framers were concerned to protect state sovereignty, it is highly unlikely that they could have foretold the Pacific Solution, where one country paid others to house refugees and asylum seekers, resulting in the violation of refugee rights through indefinite detention. Indeed, it is most unlikely that the framers could have envisaged that refugees could be sent to non-party states given the relative newness of the norm of non-refoulement and the fact that non-party states could not be expected to observe it. Hathaway cites a statement by the French representative at the Conference of Plenipotentiaries, which adopted the Refugee Convention, showing that in fact the framers expected that refugees would only be sent to other states parties and that refugee rights would be observed (Hathaway 2005: 328).

Unlike other foreigners, refugees are a partial exception to the sovereign prerogative over entry, in that they cannot be returned. It is therefore important, as Hathaway (2005: 331-333) has argued, to take a good faith approach to non-refoulement whereby at least those rights acquired at the time of arrival in a potential country of asylum are respected in any place to which the refugee is later sent. The Michigan Guidelines on Protection Elsewhere have gone a step further, stating that

any refugee transferred must benefit in the receiving state from all Convention rights to which he or she is entitled at the time of transfer. He or she must also acquire in the receiving state such additional rights as are mandated by the requirements of the Convention. (Hathaway 2007: 215)

As the High Court has helpfully framed the issue, any safe third country should operate as a 'legal reflex' of the sending country.

It is not a 'good faith' reading of the Convention to actively prevent refugees from acquiring lawful presence or stay, upon which so many rights in the Refugee Convention are predicated. Nor should a country be able to wash its hands of refugees and asylum seekers by placing them under the control of another country if it will not respect those rights (Foster 2007: 269-270). Many of the rights in the Refugee Convention, which are conditioned on factors such as lawful presence or stay, are just as vital to 
refugee survival as physical non-refoulement. One example is the right to work. As the United States delegate on the ad hoc committee responsible for drafting much of the Convention said, 'without the right to work, all other rights were meaningless. ${ }^{62}$ Survival cannot be guaranteed solely by the refusal to return refugees. Indeed, failure to accord refugee rights such as the right to work may amount to a constructive violation of the obligation of non-refoulement, ${ }^{63}$ because it may cause a person to return home (Mathew 2012: 97-99).

It is therefore troubling that the Australian parliament's response to the High Court's decision has been to amend the Migration Act so as to delete most references to human rights. Under the Migration Act as amended, the minister simply designates a country as safe through a legislative instrument, because the minister thinks it is in the national interest to do so. Under $\operatorname{sig} 8 \mathrm{AB}(3)(a)$, the minister must have regard to whether or not the country has given Australia any assurances to the effect that:

(i) the country will not expel or return a person taken to the country under section 198AD to another country where his or her life or freedom would be threatened on account of his or her race, religion, nationality, membership of a particular social group or political opinion; and

(ii) the country will make an assessment, or permit an assessment to be made, of whether or not a person taken to the country under that section is covered by the definition of refugee in Article 1A of the Refugees Convention as amended by the Refugees Protocol.

The assurances do not have to be binding (sig8AB(4)).

Either House of Parliament may choose not to approve the instrument on the basis that it disagrees with the decision to send refugees to the particular country concerned. However, it is clear that the legislators have tried to keep the courts' role in scrutinising the legislative instrument to a minimum by reducing references to objective standards against which the minister's decision may be assessed. It is also notable that the possibilities

62 Statement of Mr Henkin of the United States: UN Ad Hoc Committee on Refugees and Stateless Persons, Ad Hoc Committee on Refugees and Stateless Persons, Second Session:Summary Record of the Thirty-Seventh Meeting Held at the Palais des Nations, Geneva, on Wednesday, 16 August 1950, at 3.oo p.m., UN Doc E/AC.32/SR.37 (26 September 1950).

63 For a recent decision in which the terminology 'constructive refoulement' is used, see $M A$ and others $v$. Director of Immigration, HCAL 10/2010 and HCAL 73/2010 and HCAL 75/2010 and HCAL 81/2010 and HCAL 83/2010, Hong Kong: High Court, 6 January 2011, [82], www.unhcr.org/ refworld/docid/4fi44c282.html. 
for considering human rights during the legislative process were limited because of the haste in which the government wished to pass the new legislation ${ }^{64}$ It is concerning that people claiming refugee status - a surrogate for citizenship that enables protection by another country because their own country has failed to protect them - are treated in such an overtly politicised manner.

\section{The Court of Justice of the European Union and refugee rights under EU law}

The Court of Justice of the European Union (CJEU) has also considered the question of what rights are owed to refugees beyond non-refoulement in a case involving the construction of the Dublin Regulation, N.S. and M.E. ${ }^{65}$ In this case, the Court's point of departure was the norm of non-refoulement attached to the prohibition on torture and related ill-treatment contained in Article 4 of the Charter of Fundamental Human Rights of the European Union. ${ }^{66}$

The case concerned one Afghan applicant for asylum in the United Kingdom (N.S.) and five applicants in Ireland who were from Afghanistan, Iran and Algeria. As in M.S.S. $v$ Belgium and Greece, the purported safe country was Greece. The CJEU came to the same conclusion as the European Court of Human Rights and decided that the applicants could not be returned to Greece, owing to the established risk of inhuman or degrading treatment. However, the CJEU stated that not every violation of a refugee or asylum seeker's human rights would render a country 'unsafe'. The Court stated that in general, it 'must be assumed that the treatment of asylum seekers in all Member States complies with the requirements of the [Charter of Fundamental Human Rights of the European Union], the [Refugee] Convention and the ECHR'.67

64 At the federal level, there is a relatively new process of legislative scrutiny for compatibility with human rights: Human Rights (Parliamentary Scrutiny) Act 2011 (Commonwealth). The Refugee Convention is not one of the instruments against which scrutiny occurs, but other human rights instruments are clearly implicated by the move to offshore processing. However, scrutiny of the Migration Legislation Amendment (Regional Processing and Other Measures) Act 2012 (Commonwealth) did not occur initially because the originating bill was introduced in parliament before the human rights scrutiny arrangements came into force. An inquiry was eventually held after the passage of the legislation.

65 N.S. and M.E. (CJEU, C-411/10 and C-493/10, 21 December 2011).

66 Charter of Fundamental Rights of the European Union [2010] OJ C 83/389.

67 N.S. and M.E. (CJEU, C-411/10 and C-493/10, 21 December 2011) [8o]. 
The Court draws attention here to the fact that, unlike the Australian High Court, the CJEU has the luxury of operating in a context where all the EU states are (on paper at least) 'reflexes' of each other, to use the Australian High Court's terms. They are legally all on the same plane because they are all party to the relevant treaties, and there are two regional judicial bodies, the European Court of Human Rights and the CJEU, to hold states to account. Moreover, under Dublin, an EU member state takes full responsibility for the refugees, in the sense of determining status and granting a visa.

The assumption that all EU member states comply with those legal obligations could be described as regional parochialism or wishful thinking. The Court admitted that:

[i]t is not inconceivable that the system may, in practice, experience major operational problems in a given member State, meaning that there is a substantial risk that asylum seekers may, when transferred to that Member State, be treated in a manner incompatible with their fundamental rights. ${ }^{68}$

Therefore, the Dublin Regulation did not establish a conclusive presumption of compliance with fundamental rights. ${ }^{69}$ The Court noted that 'mere ratification of conventions by a Member State cannot result in the application of a conclusive presumption that that State observes those conventions' and further that ' $\mathrm{t}$ ] he same principle is applicable to both Member States and third countries. ${ }^{70}$

The Court was not prepared to rule that 'any infringement of a fundamental right ... will affect the obligations of the other Member States to comply with [the Dublin Regulation]. ${ }^{71}$ To do so would add criteria for determining the state responsible for hearing an asylum claim beyond those outlined in the Dublin Regulation. ${ }^{7^{2}}$ The Court was prepared to rule that transfers must not go ahead where Member States

... cannot be unaware that systemic deficiencies in the asylum procedure and in the reception conditions of asylum seekers in that Member State amount to substantial grounds for believing that the asylum seeker would

68 N.S. and M.E. (CJEU, C-411/10 and C-493/10, 21 December 2011) [81].

69 N.S. and M.E. (CJEU, C-411/10 and C-493/10, 21 December 2011) [99]-[101].

70 N.S. and M.E. (CJEU, C-411/10 and C-493/10, 21 December 2011) [103].

71 N.S. and M.E. (CJEU, C-411/10 and C-493/10, 21 December 2011) [84].

72 N.S. and M.E. (CJEU, C-411/10 and C-493/10, 21 December 2011) [85]. 
face a real risk of being subjected to inhuman or degrading treatment within the meaning of Article 4 of the Charter. ${ }^{73}$

There is thus a question as to whether and on what basis the Court might find a refugee not returnable with respect to other rights (Lieven 2012: 236). The opinion of the Advocate General at the Court, which preceded the Court's judgment, suggested a threshold of 'serious risk of violation of an asylum seeker's fundamental rights as enshrined in the Charter of Fundamental Rights. ${ }^{74}$

Regarding the evidence required to show whether there is a risk of a violation of Article 4 of the Charter, the Court ruled that member states should look at the same sources of evidence examined by the European Court of Human Rights in M.S.S. $v$ Belgium and Greece..$^{75}$ This evidence included

... the regular and unanimous reports of international non-governmental organisations bearing witness to the practical difficulties in the implementation of the Common European Asylum System in Greece, the correspondence sent by the United Nations High Commissioner for Refugees ... to the Belgian minister responsible, and also the Commission reports on the evaluation of the Dublin system and the proposals for recasting Regulation No 343/2003 in order to improve the efficiency of the system and the effective protection of fundamental human rights. (M.S.S. $v$ Belgium and Greece, $\S 347-350)^{76}$

The Court noted that member states were aware of the concerns about the Dublin system given the Commission reports on it. ${ }^{77}$ The Court found that the returns to Greece should not proceed, and if necessary, the so-called 'sovereignty clause' in the Dublin Regulation should be invoked and the countries concerned (in these cases, the United Kingdom and Ireland) should accept responsibility for determining refugee status themselves..$^{78}$

The persuasive value of the judgment (that is, the influence it may have on courts elsewhere) may be limited because it rests on an interpretation

73 N.S. and M.E. (CJEU, C-411/10 and C-493/10, 21 December 2011) [94] and dispositif.

74 See Opinion of Advocate General Trstenjak, Case C-411/10 (N.S. $v$ Secretary of State for the Home Department) (22 September 2011) [127].

75 N.S. and M.E. (CJEU, C-411/10 and C-493/10, 21 December 2011) [91].

76 N.S. and M.E. (CJEU, C-411/10 and C-493/10, 21 December 2011) [9o].

77 N.S. and M.E. (CJEU, C-411/10 and C-493/10, 21 December 2011) [92].

78 N.S. and M.E. (CJEU, C-411/10 and C-493/10, 21 December 2011) dispositif. 
of the relevant EU legislation and the objects of this legislation - namely to assure allocation of responsibility and efficient handling of asylum claims. ${ }^{79}$ The Court accepted that the state responsible for determining an asylum claim under Dublin may be the sole state responsible for some violations of human rights, limiting itself to ruling on the question of violation of the prohibition on torture and related ill-treatment, which, of course, carries a non-refoulement obligation and necessarily implicates both sending and receiving countries.

This contrasts with the legislation being interpreted by the High Court in $M 70$, which, reflecting the idea that a safe third country should operate as a 'reflex' ${ }^{80}$ of Australia's own obligations, required a safe third country to respect all the refugee rights guaranteed by the Refugee Convention as a prerequisite for transfers. On the other hand, the High Court's decision also has some limitations, as the majority of the High Court did not reach the issue of when legal guarantees would be insufficient and the practical situation on the ground should be examined, which is what the CJEU was asked to consider.

As mentioned earlier, the Australian parliament has now amended the legislation so as to make it clearly incompatible with the reading of international law advocated in this chapter, and the Court is not empowered to strike the new legislation down on the basis of incompatibility with international law. This leads to some important questions about the role of the law in securing refugee protection.

\section{Conclusion}

The decisions examined in this chapter highlight the differences, especially in a legal context, between the regions within which the agreements considered by the courts were adopted. The Asia-Pacific region is significantly different from the European region in terms of acceptance of human rights instruments. For example, while there is generally a good rate of ratification of the Convention on the Elimination of all Forms of Discrimination against Women ${ }^{81}$ and the Convention on the Rights of the Child, participation by Asian states in other universal human rights treaties is limited. There is also

79 N.S. and M.E. (CJEU, C-411/10 and C-493/10, 21 December 2011) [84].

$80 \quad M 70$ (2011) 244 CLR 144 [118] (Gummow, Hayne, Crennan and Bell JJ).

81 Convention on the Elimination of All Forms of Discrimination against Women, opened for signature 18 December 1979, 1249 UNTS 13 (entered into force 3 September 1981). 
no generally applicable regional human rights instrument, although the ASEAN Intergovernmental Commission for Human Rights was established in October $2009^{82}$ and it adopted the ASEAN Declaration of Human Rights in 2012. There is also a Commission for the Promotion and Protection of the Rights of Women and Children, which uses the relevant international treaties as a basis for its mandate. ${ }^{{ }^{3}}$ Unlike the European or the African and American regions, there are also no regional instruments specifically governing the treatment of refugees, let alone multilateral agreements that deal with the allocation of responsibility for asylum claims or the sharing of responsibilities through resettlement. ${ }^{84}$ Despite the different contexts in which the courts are operating, however, the decisions examined in this chapter demonstrate a common reaction by the judiciary to countries' attempts to avoid obligations they owe to refugees and asylum seekers. The European courts have rejected blanket assumptions of safety based on treaty obligations, while the Australian High Court rejected pious hopes of human rights protection based on a non-binding MOU.

In the immediate aftermath of the $M 70^{85}$ decision, some commentators in Australia questioned the significance of a treaty safeguard as opposed to an MOU (Menadue 2012; Kelly 2011). Each represents 'the word' of the relevant governments. In most cases, MOUs are not governed by the maxim 'pacta sunt servanda' (promises are binding, treaties must be obeyed), but human rights treaties are often dishonoured in practice. However, that treaties are often violated with few consequences should be no reason for us to place our faith in a document that is expressly non-binding, particularly when the rights of vulnerable asylum seekers are at stake. Rather, it is an argument to also consider whether treaties are implemented through domestic law and what the practice is like on the ground. This is particularly true when one of the most controversial aspects of the Malaysia swap, as far as the Australian public was concerned, was the revelation that unauthorised migrants and

82 Association of Southeast Asian Nations (ASEAN), Terms of Reference of ASEANIntergovernmental Commission on Human Rights (July 2009).

83 Association of Southeast Asian Nations (ASEAN), Terms of Reference of the ASEAN Commission for the Promotion and Protection of the Rights of Women and Children (ACWC) (February 2010).

84 This may be contrasted with the Mexico Declaration and Plan of Action to Strengthen International Protection of Refugees in Latin America, 16 November 2004, under which 'solidarity resettlement' has been initiated. In June 2006, the Organization of American States endorsed the Mexico Declaration and Plan of Action: see OAS General Assembly Resolution 2232: Protection of Asylum Seekers, Refugees, and Returnees in the Americas (June 6 2006) 4th sess, OAS Doc AG/ RES 2232 (XXXVI-O/o6).

85 M7o (2011) 244 CLR 144. 
asylum seekers are sometimes judicially caned for immigration offences. ${ }^{86}$ Reliance on governmental or diplomatic assurances like an MOU has been controversial in the context of allegations of torture or inhuman/degrading treatment or punishment, precisely because diplomatic assurances are sought when it is acknowledged that there is a risk of torture. In such cases, it is difficult to see why governmental assurances would make a difference (see Mole \& Meredith 2010). ${ }^{87}$

It might be argued that Asian governments may not put the same emphasis on international law and adjudication, for a variety of reasons, which perhaps should be understood and worked with rather than condemned. However, it cannot realistically be argued that law and legal status are simply not important in Asian countries, given the active denial of legal status to irregular migrants, the growing acceptance of international adjudication in areas other than human rights (Saul, Mowbray \& Baghoomians 2011:121) and the moves within ASEAN to create a regional human rights framework. If there is a commitment to human rights that can be relied upon by others, why should we not expect the form of the commitment to adhere to the norm of a treaty commitment that recognises these as rights inherent to the individual as opposed to a 'gentleman's agreement'?

The court decisions examined in this chapter have demonstrated that trying to discourage people from undertaking dangerous journeys must not operate as an excuse to violate international law. While the courts can rule on the consistency of regional arrangements with human rights provisions (whether contained in a treaty or reflected in national legislation), they are usually only able to react to events that have already unfolded. As countries in Europe and the Asia-Pacific grapple with the problem of life-threatening journeys made by asylum seekers, particularly those made in the Mediterranean Sea and the Indian Ocean, calls are being made for proactive arrangements (Expert Panel on Asylum Seekers 2012).

86 In a poll published in the tabloid newspaper The Daily Telegraph, over 66 per cent of participants said they wanted the Australian government to back away from the Malaysia agreement (Jones 2011).

87 Report of the UNSpecial Rapporteur of the Commission of Human Rights on torture and other cruel, inhuman or degrading treatment or punishment to the UN General Assembly, UN GAOR, 6oth sess, Provisional agenda item 73(a), UN Doc A/6o/316 (30 August 2005) [31]-[32]. See also the 2011 UN General Assembly Resolution on torture and other cruel, inhuman or degrading treatment or punishment: General Assembly Resolution on torture and other cruel, inhuman or degrading treatment or punishment, GA Res 65/205, UN GAOR, 3rd Comm, 65th sess, 71st mtg, Agenda Item 68(a), UN Doc A/RES/65/205 (28 March 2011) [16]. But see, Othman (Abu Qatada) $v$ United Kingdom (European Court of Human Rights, Fourth Section, Application No 8139/og, 17 January 2012). 
Often, however, the measures are simply meant to act as deterrents and do not deal with the reasons for refugee movement. In most cases, unauthorised boat arrivals have good cause to enter Australia because they are unable to secure protection in the vast majority of countries in the Middle East and the Southeast Asian region.

Respect for the law is a wise policy choice. Attempts at containment of refugees in regions that are not necessarily well equipped to protect them may well encourage dangerous journeys (see Taylor \& Rafferty-Brown 201ob; Human Rights Watch 2002). This courts disaster at sea as well as in the courts. Refugees and asylum seekers pose an important question for Asian countries - one that needs to be addressed. The real issue to be discussed between Australia and its neighbours is whether it is possible to develop a responsibility-sharing arrangement in which more countries in the region are encouraged to ratify the Convention and Protocol and implement them in the long term. Australia will have to do rather more than offer 4,00o resettlement places over four years in exchange for some returns if its goal is to secure more participation in international refugee law.

A political reconception of the role of regional agreements by governments is needed if they are to serve the interests of irregular migrants and governments everywhere in a fair manner. This is a matter for political leadership, in which an independent judiciary plays only a supporting role.

This research was supported by the Australian Research Council's Discovery Projects funding scheme (project number 120102224). The author thanks Tristan Harley for his assistance in the research and for his comments on earlier drafts of the chapter. 



\title{
10 Maritime pathways
}

Temporary migration flows from Indonesia to Australia

\author{
Marshall Clark \& Dedi Supriadi Adhuri
}

\section{Introduction}

Temporary migration creates opportunities for individuals, households and states (Oke 2012). In recognition of this, in Australia increasing numbers of migrant workers from Southeast Asia are being granted temporary visas to undertake short-term or seasonal work, particularly in health care, construction and the mineral resources sector (Kukoc 2012). This chapter focuses specifically on the nature of temporary migration flows in Australia and some of the political hurdles that underpin Australia's temporary migration programmes. We focus on temporary migration in one industry in particular, namely the Australian commercial fishing industry. In comparison with other industries that employ large numbers of migrant workers in Australia, the Australian fishing industry does not attract a significant number of overseas workers. This is partly related to the fact that issues involving temporary migration and fishing such as people smuggling and the boarding of asylum seekers on Indonesian fishing boats have become heavily politicised in Australia. Media references to a 'crisis' in Australia's northern border protection - which includes the deterrence of illegal, unreported and unregulated (IUU) fishing, people smuggling, and other criminal or even potentially terrorist activities - are now commonplace.

This chapter will examine temporary migration flows of skilled labour in Australia and New Zealand. In drawing on the New Zealand experience, this chapter explores whether a temporary migrant labour programme involving Indonesian labour in the Australian fishing industry could be revitalised through building on the established historical connections between Indonesians and Indigenous communities in northern Australia. In doing so, we provide a broader perspective on the common narrative of irregular migrants travelling by boat from Indonesia to Australia that is negatively focused on 'illegal fishing' and 'people smuggling'. On both sides of the political spectrum, Australia's long-term response to irregular migration from Indonesia has been reduced to a technical matter of finding ways to 'stop the boats' (see chapter 8 in this volume). By exploring Australia's 
history of temporary migration flows, it can be shown that temporary migrants working in Australian waters have not always been viewed with such suspicion.

The use of temporary migrant labour in Australian fisheries is not a new phenomenon; from the early 1700 s onwards, large fleets of trepang (bêche-de-mer or sea cucumber) fishers from the eastern Indonesian port town of Makassar on the island of Sulawesi, known as 'Macassans', regularly interacted with the indigenous communities of northern Australia. According to some, the Macassan trepang industry was Australia's first-ever export industry, and Campbell Macknight refers to it as 'Australia's first modern industry' (1976:1). For two centuries or more, hundreds, if not thousands, of Indonesian trepangers worked Australia's northern waters, continuing to do so until 1907 when the South Australian government effectively closed down the fishery through the decision not to issue licences (Macknight 1976).

In the contemporary era, there are suggestions that some modern Australian fisheries are operating under capacity, in part due to labour shortages. This has occurred in the broader context of one of the most heavily regulated fishing industries in the world (see, for example, Lloyd 2012). In the last decade, Australia's fishing fleet has been dramatically reduced in size, coinciding with quota reductions and a shortage of manpower. This has opened the door to the introduction of the Fishing Industry Template Labour Agreement, which is a policy and framework for Australian fishing operators to sponsor and employ temporary migrant workers. The template was introduced in 2011 after extensive consultation with fishing operators seeking fishing and deck hands, and with various government and industry bodies. The agreement is meeting the needs of a number of Australian fishing operators who are sourcing their migrant workers almost exclusively from Indonesia. Importantly, the agreement also provides considerable protections for the temporary migrant workers. As of July 2012, seven such agreements have been negotiated involving 71 Indonesian fishing and deck hands.

We begin this chapter with an examination of the question of temporary migration, particularly in the context of migration pathways between the Pacific region and Australia. The positives and negatives of temporary labour migration schemes - such as Australia's Pacific Seasonal Worker Pilot Scheme (PSWPS) which allows Pacific Islanders to fill seasonal shortages in the horticulture industry - will be examined. We then explore the potential problems of expanding or adapting such schemes in the Australian context. As mentioned earlier, we have chosen to focus on the fishing industry, which has significant historical connections with Indonesia. Our discus- 
sion concludes with a few modest reflections on the potential impact of temporary labour migration flows to Australia, involving Indonesian fishing crew and deck hands in particular, on Australia's maritime border issues.

\section{Temporary labour migration: Australia and the Pacific Islands}

The World Bank (2006) has recommended seasonal migration programmes involving unskilled, low-skilled or semi-skilled labour as one of the most promising ways to enhance the development benefits of migration. Despite some scepticism about the capacity of temporary migration to act as a development strategy (see, for instance, Phillips 2009), the World Bank perspective is largely supported by academics (see, for instance, Amin \& Mattoo 2005; Koettl 2006; Pritchett 2006; Rodrik 2007; Winters et al. 2005) and, more recently, by governments (see Gibson \& McKenzie 2010). Indeed, temporary labour migration schemes are widely used in the developed world and are increasingly seen as offering a potential 'triple-win' (Gibson \& Mackenzie 2010) - that is, receiving countries benefit from the injection of low-skill labour; migrant workers frequently benefit from the much higher wages that they receive; and, through the remittances they send home, their country of origin also benefits. Seasonal migration programmes are especially important for the Pacific Island countries, many of which are facing population pressures and few alternative economic opportunities. Globally, the development impact of remittances is enormous. In 2011, India and China received USD 64 and USD 62 billion respectively in migrant remittances (Ratha \& Silwal 2012:2). In Tonga, 27 per cent of its gross domestic product (GDP) comes from money sent home by temporary migrant workers; Samoa has a similar figure (Brown, Leeves \& Prayaga 2012: 5). According to a World Bank report (Ratha \& Silwal 2012:1), remittance flows to developing countries are estimated to have reached USD 372 billion in 2011, an increase of 12.1 per cent from the previous year. Remittance flows to developing countries are expected to grow at 7-8 per cent annually to reach USD 467 billion by 2014. These are official records of hard-earned dollars sent home and, since a lot of money moves informally, the true figure may be much higher, perhaps by as much as 50 per cent or more (World Bank 2006: 85).

Despite increasing evidence of the benefits of unskilled migration from developing countries to developed countries, there are concerns that temporary labour migration has negative social effects. One negative impact is the long-term separation of a parent from a spouse and children (Maclellan 2008). In general, however, temporary migration improves household income 
and improves the ability of the family to make compensating adjustments to mitigate the hardship of the family member's absence. Improvements in the health and schooling of children left behind, financed by remittances, coupled with strong involvement of the extended family, tend to mitigate the social costs of a parent's migration (World Bank 2006).

In receiving countries, there are concerns that temporary migration undermines wages and conditions and encourages exploitation, that it threatens the job prospects of unemployed or underemployed citizens of the receiving country, that it increases crime, that it leads to visa overstaying, and that it fosters dependency in source nations (Mares 2007). Yet a preliminary study of New Zealand's Recognised Seasonal Employer (RSE) programme shows little displacement of New Zealand workers, very low overstay rates (one per cent or less) and only a few isolated cases in which concerns about worker exploitation have arisen (Howes 2010; New Zealand Department of Labour 2010). ${ }^{1}$ Nevertheless, Oke (2012) argues that in the Australian experience, temporary migration does create certain vulnerabilities, mainly for those workers undertaking low-skilled work. With the exponential increase in temporary migration in recent years, cases of mistreatment, underpaying or underemployment of foreign labourers have increased. Research has indicated, however, that most temporary migrants on the 457 skilled work visas are largely positive about working in Australia, mainly because of the higher wages they receive than in their home countries (Khoo, McDonald \& Hugo 2005; 2006).

Historically, temporary work visas have been used only minimally in Australia, but they now comprise a significant component of the nation's migrant intake. As Oke (2012) observes, at its peak between 2007 and 2008, more temporary skilled work visas were issued than permanent skilled settlement visas. Over the past decade, two seasonal migration schemes have been introduced in New Zealand and Australia - the RSE (New Zealand's Recognised Seasonal Employer scheme) and the PSWPS (Australia's Pacific Seasonal Worker Pilot scheme). Both schemes have been aimed at allowing Pacific Islanders to fill seasonal labour shortages in the horticulture industry. The New Zealand scheme was introduced in 2007 with a view to solving the longstanding labour shortage in New Zealand's horticulture industry while also boosting the economic growth and productivity of this particular sector. Another key aim of the New Zealand government was

1 Foreign charter vessels operating in New Zealand waters, however, have been accused and charged of a raft of shortcomings, including underpaying foreign crew, human rights abuses and fishing offences (Stringer, Simmons \& Coulston 2012). 
to allow this scheme to assist in its broad development objectives in the Pacific region. With over 8,ooo Pacific Islanders employed annually, the policy addressed seasonal labour shortages (New Zealand Department of Labour 2010). In comparison, the Australian PSWPS, launched in 2008, had attracted only 1,100 workers in total by 2012, so its positive development impact was limited (Howes 2010; Hay \& Howes 2012).

There are several reasons why the RSE has been regarded as an overwhelming success and the PSWPS as a relative failure. First of all, New Zealand fruit growers are primarily geared to the export market, which in practical terms translates to an emphasis on quality. The fruit needs to be picked selectively and handled carefully. This is possible with Pacific Islander pickers, many of whom have what is referred to in the industry as 'soft hands'. Growing up in the Pacific Islands, they are generally familiar with handling fruit (Maclellan 2008). At least half of the Pacific Islander workers are experienced 'return pickers', returning to the same farms to work on the same crops in subsequent seasons and thus ensuring they retain their skills and local knowledge (New Zealand Department of Labour 2010). Consequently, the Pacific Islanders have quickly developed a reputation for being good workers. According to growers, they tend to be reliable and work long shifts, in both hot and cold weather conditions, with little absenteeism (Bedford 2012). Secondly, besides local labour, the primary alternative cohort of pickers, European backpackers, tend to be inexperienced, unreliable, poorly motivated and rarely become 'return pickers', as they are not interested in circular migration. For the backpackers themselves, the lack of a 'visa sweetener' - the promise of a visa extension based on an exemplary period of work in the horticulture industry - encourages irregular participation. ${ }^{2}$ Third, New Zealand has a Pacific-friendly culture. With many citizens of Pacific ethnicity already living in New Zealand, including large expatriate communities of Samoans and Tongans, church groups in particular have embraced the Pacific workers (New Zealand

2 This aspect of the backpacker experience has been improved, with New Zealand's Department of Labour initiating the Working Holidaymaker Extension Visa in November 2010. The rules are as follows: 'If you are in New Zealand on a working holiday visa and you are able to show you have undertaken three months or more of seasonal work in the horticulture and viticulture industries during your working holiday, you may apply for the Working Holidaymaker Extension Visa. Successful applicants will be granted a work visa for an additional three months from the expiry date of their working holiday visa. The visa will have the same conditions as the original working holiday work visa, including travel conditions' (New Zealand Department of Labour 2012). Further evaluation is needed to ascertain whether this initiative has led to an increase in the number of backpackers working on farms in New Zealand. 
Department of Labour 2010). Although the term 'pastoral care' has not been used in government literature on the scheme, church communities have enthusiastically adopted this role, promoting a positive temporary migration experience and thus engendering a pattern of circular migration (Bedford 2012). Growers have also taken on a pastoral or management responsibility, some more enthusiastically than others, encouraging temporary migrant workers to take up accommodation onsite and adopt a 'no drinking' policy (Roorda 2012). Fourth, because workers tend to be employed from the same Islander community, they have a strong sense of familiarity and loyalty to each other which encourages exemplary behaviour. Workers have also been encouraged to uphold their home country's reputation, which has also had a positive behavioural effect (Roorda 2012).

Although the take-up of Australia's PSWPS has been increasing, it is still very low. There are several theories for its relative failure, namely the prolonged drought, the surge in backpacker numbers, the costs of excessive bureaucracy and the presence of 'illegal' or undocumented workers. Let us first consider the questions of the prolonged drought and the backpacker boom. Almost five years after the scheme's establishment, preliminary analysis suggests that fruit growers in Australia were satisfied with their labour supply (Hay \& Howes 2012). This is in stark contrast to the findings of an earlier survey conducted before the scheme commenced, which suggested that there was a serious shortage of available workers to meet peak seasonal demand for labour, particularly in the horticulture industry along the Murray River between Swan Hill and Mildura (Mares 2006). This shift may have been caused partly by the prolonged and severe drought affecting many parts of Victoria and New South Wales over much of the second half of the last decade, with subsequent shortfalls in production. Growers operating in the context of drought - and, in recent years since the drought broke, in the context of unseasonal rainfalls and widespread floods - have found the steady supply of backpacker labour satisfactory. The backpacker Working Holiday Visas (Subclass 417) were introduced at the same time as the PSWPS was initiated and have proven to be a success, with large numbers of backpackers working in rural Australia. A 'visa sweetener' arrangement has also proven to be influential; backpackers who work in a regional area for three months in agriculture, horticulture, construction, mining and fishing are entitled to stay on for an extra year. In 2011, the number of backpackers working on Australian farms increased from 13,000 in 2001-2002 to 37,000 in 2007-2008, 22,000 of whom applied for a second year's visa on the basis of successful completion of their first year of seasonal work (Hay \& Howes 2012). 
The relative unpopularity of the PSWPS has also been blamed on the costs associated with it, including the burden of red tape engendered by bureaucratic requirements, which has not been an issue for the Working Holiday Visa scheme. PSWPS-approved employers were obliged to contribute 5 o per cent of the cost of the international return trip for Pacific seasonal workers. Although the costs have now been reduced, there is still red tape involved, as growers must pay the full cost of the workers' airfares to and from Australia up front and recoup a percentage of that cost from the worker. The Working Holiday Visa scheme, however, does not require growers to pay a share of the costs, such as airfares, as backpackers pay their own airfares to and from Australia and they make their own way to fruit-growing regions. Growers employing backpackers are not required to provide onsite accommodation or pastoral care, which are obligations under the much more heavily-regulated PSWPS. In general, PSWPS-approved employers have been reluctant to shoulder the administrative and organisational costs of the scheme (Hay \& Howes 2012). Another reason for Australian horticulture operators' reluctance may be to avoid close liaison with government departments, as some continue to use the undocumented labour of illegal migrants to fill labour shortfalls. In the lead-up to the implementation of the RSE, the New Zealand government increased crackdowns on undocumented labour and rogue labour brokers, which in turn increased the demand for legal workers (Bedford 2012; Roorda 2012). There was no such crackdown on undocumented workers in Australia. Ultimately, besides the effect of the prolonged drought, issues such as costs, excessive bureaucracy, illegal or undocumented workers and the relative ease of obtaining backpacker workers have outweighed the potential benefits of the PSWPS.

Despite its teething problems, the Australian government has been determined from the outset to continue and expand the PSWPS beyond the initial four Pacific countries chosen for the scheme's pilot phase - Vanuatu, Kiribati, Tonga and Papua New Guinea (Maclellan 2008). Aware of the possibility of the scheme's expansion, the East Timorese government lobbied successfully for Timorese workers to be involved in the scheme. A cohort of several hundred East Timorese workers arrived in late 2011 in the Broome region of Western Australia. In the five years since the pilot scheme was established, calls have been made to broaden the scheme's somewhat narrow focus on horticulture to other industries, such as aged care, mining and fishing. The Australian government has demonstrated a measure of flexibility in this regard, flagged by a renaming of the scheme - from 1 July 2012 it became known as the Seasonal Worker Program (SWP). The Program is open to employers in the horticultural industry and seasonal workers 
from East Timor, Kiribati, Nauru, Papua New Guinea, Samoa, Solomon Islands, Tonga, Tuvalu and Vanuatu (Australian Department of Education, Employment and Workplace Relations 2012). In relation to the new scheme, a small-scale, three-year trial of seasonal labour mobility arrangements with cotton and cane growers, aquaculture ventures and accommodation providers in the tourism industry will be undertaken. The East Timorese cohort of workers mentioned above is an early manifestation of this change in focus. After a large tourism industry employer in Broome demonstrated that it could not source local labour, the Timorese workers were placed as hotel maids in the tourism sector (Roddam 2012), a move that may be replicated elsewhere. The Australian Tourism Export Council has reported thousands of job vacancies in the tourism sector, and changes to the visa system, such as the SWP and the extension of backpackers' Working Holiday Visas, could help to fill them: 'There are 36, ooo tourism vacancies right across this country at this very moment and by 2015 that is projected to go up to 56,000 vacancies' (McDonald 2012). Western Australia, in particular, is facing labour and skills shortages in many industries. According to a spokesman of the Western Australia Chamber of Commerce and Industry, 'If we don't boost the current growth in the workforce, WA will fall 210,000 workers short by the end of the decade. In certain industries, there are simply not enough workers locally to meet demand' (Perpitch 2012).

A key component of the PSWPS - pastoral care - has remained a primary focus of the SWP, with approved employers expected to arrange accommodation of a suitable standard, health insurance and transport to and from work. Employers are also obliged to assist workers with initial living expenses on their arrival if required and with access to personal banking, gaining a tax file number, preparing a tax return and applying for superannuation entitlements. In the case of the East Timorese cohort in Broome, a caseworker employed by the East Timorese government has been assigned to monitor the pastoral needs of the workers. Given that language is likely to be a potential barrier for workers from East Timor, the availability of an East Timorese caseworker is entirely appropriate. Writing about calls for an expansion of 457 visas in the mineral resources sector, Barry (2012a; 2012b) argues that workers from different cultural contexts, with non-English speaking backgrounds, might face greater challenges at the workplace. Indeed, workplace health and safety concerns were raised in the Australian government's explanation of a move in 2012 to expand the numbers of migrant workers from the United States, who are more likely to be fluent English speakers (Barry 2012b). Most of these employees will be placed in the construction sector, where much of the unmet demand 
for labour is in the development of large-scale mining projects (ABCNews, 2 April 2012).

Labour shortages in Australia's resources sector have also been much debated in recent times, especially as there is now a concerted push to open up employment to larger numbers of skilled migrant workers (see, for instance, Thomson 2012). Mining companies are now allowed to bring in large numbers of temporary foreign workers under Enterprise Migration Agreements (EMAs), which were first earmarked in 2011. Designed to address current labour shortages in the resources sector, EMAs are an industry-specific temporary worker programme. The existing temporary skilled work visas, the 457 visas, have also been increasingly used in the mining industry. Unlike labour schemes such as the RSE and PSWPS/ SWP, however, foreign workers are generally recruited directly by mining companies, with little emphasis on the pastoral welfare of the workers and their families. Truth be told, very little is known about the day-to-day experience of migrant workers in the mining industry. There are various possible reasons for this, including the secretive nature of the initial employment contract, the geographical isolation of the work placement, and workers' reluctance to speak out against their employers.

The welfare concerns of Australian short-term mining industry workers - known as 'fly-in, fly-out' (FIFO) workers because they often commute between major capitals and remote mining towns in the outback - are also given short shrift. The adverse social effects associated with FIFO workers are only now coming to light in the Australian media (see, for example, Laurie 2012), but there is little scholarly evaluation of the true impact. Besides fatigue and isolation from friends and family, the main problem is the FIFO workforce's demanding rosters, the most common of which is two weeks on (at work), one week off (at home). The influx of temporary workers is also unsettling for remote mining communities, whose residents are largely unable to gain employment in the mining industry (West Australian, 28 March 2012). But in the future, according to one newspaper report, with AUD 200 billion worth of new iron ore and gas projects in the pipeline until 2015, the temporary workforce is destined to get 'much, much bigger' (Laurie 2012: 13). The Western Australian Chamber of Minerals and Energy claims that 38,000 more workers are needed in the state by early 2013; they will join 92,500 already employed in the resource industry, $5^{2}$ per cent of whom are FIFO workers (Laurie 2012). Notwithstanding the human problems associated with FIFO workforces, unions are concerned about the long-term capacity of foreign labour, if it is to be greatly expanded, to undercut local employment conditions. Although Australian wages cannot be undermined, 
the presence of foreign labour can certainly suppress upwards pressure on wages. The onus is on employers, therefore, to demonstrate their need for foreign workers by proving that they cannot source local labour. The following section will focus on another sector of the Australian economy, the fishing industry, which is somewhat belatedly recognising the need to systematically employ larger numbers of temporary migrant workers.

\section{Indonesian temporary migrant workers in the Australian fishing industry}

As of July 2012, there were 71 foreign crew working in Australia's commercial fishing industry, all of them Indonesian. ${ }^{3}$ Many more are needed, but, owing to the bureaucratic obstacles in negotiating a semi-skilled labour agreement, supply is failing to meet demand. The supply of experienced local labour is declining for many reasons. In terms of the local labour shortfall, according to Trixi Madon, 'there are already many labour challenges facing the fishing industry: the workforce is ageing, there are fewer younger people attracted to the industry, other competing industries are having a significant impact on workers available' (Commonwealth Fisheries Association 2012). This summation has been echoed by several fishing entrepreneurs and industry representatives interviewed in the course of writing this chapter, who uniformly complain of the shortage of experienced Australian fishing and deck hands. In response to this problem, over the last decade there has been strong interest in initiating a temporary visa programme for unskilled migrant workers to work on Australian vessels. Efforts to achieve this have been subsumed by the growth in the 457 temporary skilled work visas, which have allowed modest numbers of foreign deck and fishing hands to work on Australian vessels. As mentioned earlier, the Fishing Industry Template Labour Agreement was introduced in 2011 after extensive consultation with fishing operators and government and industry bodies, dating back to at least 2010 (Cleary 2010).

The 2011 agreement is meeting the needs of a small number of Australian fishing operators who now source their workers almost exclusively from Indonesia. By all accounts, Indonesian fishing and deck hands make good crews. Recruited by Australia-based labour brokers, they usually serve under an Australian captain and are praised for being strong, experienced

3 Our thanks to Brooke Thomas, director of the Labour Agreements Section, Australian Department of Immigration and Citizenship, for this information. 
and dependable fishermen, with exemplary behaviour. These days, few eyebrows are raised in the Australian commercial fishing industry about reports of vessels manned by foreign crew, which sheds doubt on claims that Australians are not yet ready for an influx of foreign labour (Mares 2006). Foreign workers on Australian vessels are, in general, accepted, as they are in Australia's fruit-growing regions, construction sites, mines and aged care facilities. Indeed, some commentators have argued that temporary labour migration, although controversial, makes good policy sense (see, for example, Sloan 2012). Private fishing operators, many of whom are operating under capacity because of a shortage of experienced crew, concur. As in key labour receiving countries such as the United States and Malaysia, Australia's economy is dependent on migrant labour, both temporary and permanent. Moreover, in some sectors of the economy, such as the commercial fishing industry, demand is much greater than supply.

For some, allowing Indonesians in particular to work in the contemporary Australian commercial fishing industry could be regarded as a nostalgic gesture, if not a security risk. On the one hand, the Macassan trepangers were an important element of Australia's early history. However, the days of the Macassan trepang industry have long since passed; the Indigenous communities of northern Australia are now Australian citizens subject to Australian federal, state and territory laws, and the trepang fishers of Sulawesi and elsewhere are now Indonesian citizens and, therefore, subject to strictly enforced laws relating to fishing in Australia's northern waters. If, perchance, fishermen from Sulawesi, or any other part of eastern Indonesia for that matter, were to seek to reclaim their centuries-old tradition of trepang fishing in Australian waters, they would be, and quite often are, apprehended, imprisoned and sentenced as 'illegal fishermen' or 'poachers' (Fox \& Sen 2002; Francis 2006; Ganter 2006). ${ }^{4}$ Australian maritime authorities, in their endeavours to strictly enforce the 1991 Australian Fisheries Management Act, treat poaching seriously. Besides experiencing detention and, ultimately, deportation, their vessels, fishing gear and catch, are also systematically forfeited to the Australian authorities and destroyed (Fox \& Sen 2002; Stacey 2007).

After the election of the Labor government in 2007 and the systematic dismantling of the former conservative government's so-called Pacific

4 An exception to this is the provision for 'traditional' Indonesian fishermen to fish using 'traditional' vessels and fishing techniques in the Australian Fishing Zone (also known as the MoU Box, because it was established after an MoU was signed between the Australian and Indonesian governments in 1974). 
Solution (the offshore detention of asylum seekers in Pacific island states), the resurgence in the number of Indonesian vessels transporting asylum seekers and refugees to Australian shores has added to the sensitivity of this issue. This was exacerbated by the failure of the Labor government's Malaysia Solution (see chapter 9 in this volume). The transition towards a new Pacific-oriented solution with the second Rudd government and the new Coalition government of 2013 has barely improved the situation (see chapter 8 this volume). Subsequently, the problem of smuggling irregular migrants on Indonesian fishing vessels has become a serious political problem for both the Labor and Coalition governments. For many, the fine line between 'illegal fishermen' and 'people smugglers' has been blurred. ${ }^{5}$

The relative abundance of certain types of marine products such as trepang and trochus still attracts stray Indonesian fishing vessels to the Australian Fishing Zone, despite the great costs incurred if these IUU vessels are detected and apprehended. Illegal trepang fishing has a long history in the waters of Australia's northern shores. After the Macassan fishing fleets made their last annual journey to Arnhem Land in 1907, Indonesian trepangers continued to fish illegally in Australian waters, especially in the Timor Sea, for decades afterwards. They ceased altogether during the Japanese occupation of East Asia from 1942 to 1945 (Fox \& Sen 2002). But trepang gathering began again in the offshore islands and reefs in the Timor Sea, particularly at Scott Reef, Seringapatam and Browse Island, where traditional fishers are permitted to operate according to the rules and regulations of the so-called 'MoU Box', an area of Australian water in the Timor Sea, using traditional fishing methods only (see Figure 10.1). Thus in one sense Indonesian fishing of trepang has continued legally, even though Australian governments have been determined to clamp down on any forms of illegal fishing as well as the catching of sharks for their fins (Francis 2006; Gibson \& Razak 2011; Howlett 2011). Shark-fin fishing regularly occurs in Australia's waters, as Indonesian fishers in search of shark are routinely slipping out of the MoU Box into Australian waters.

In relative terms, it can be argued that, for the time being, Indonesian fishers are not returning to Australian waters in large numbers. Nevertheless, as we have argued, IUU fishing still occasionally occurs and Indonesian fishers continue to be caught. Why? If we consider the so-called 'push' factors, in Indonesia - not to mention Southeast Asia and the South Pacific in general - the combination of elevated export prices and strong demand 
Figure 10.1 The MoU Box

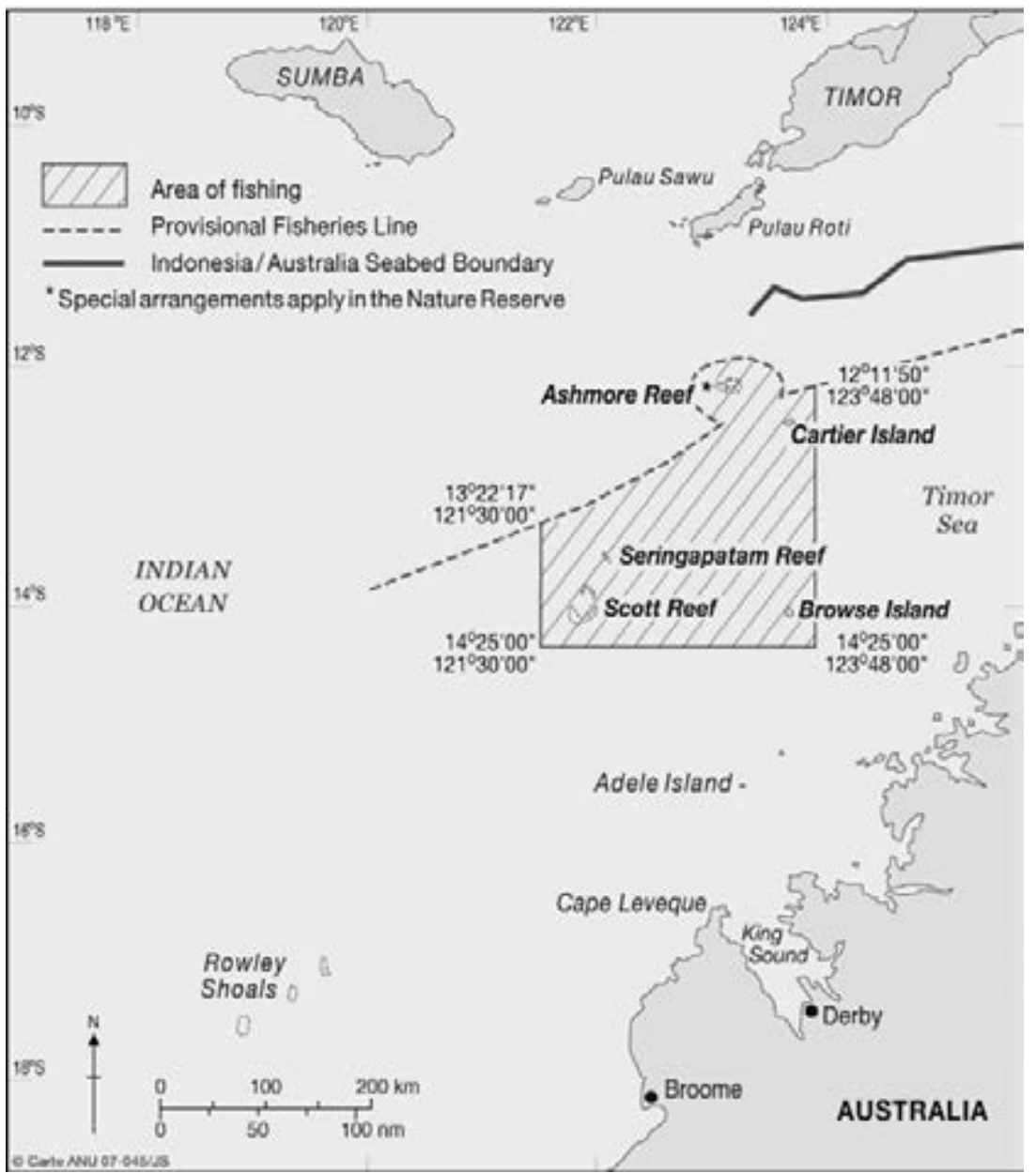

from Chinese markets for products such as trepang and shark fin has led to serious overfishing in Indonesian waters. While Indonesia is ranked fourth in the world in terms of fish production, most of its fisheries are either overexploited or fully exploited (Williams, 2007, p. xi). Local fishers can only be partly blamed for this. The real culprits are the foreign trawlers originating from China, Taiwan and the Philippines, many of whom use extremely destructive fishing methods. According to one report, each year foreign vessels take more than 1.5 million tonnes of fish illegally from Indonesian waters and, with no coastguard to speak of and a chronically under-resourced naval force, there is not much Indonesian authorities 
can do about it (Lindsay \& Pulungan 2013). Economic pressures, if not outright poverty, are forcing Indonesian fishermen to roam further afield in ever-increasing concentric circles. As their gaze, if not their operational range, roams further over the horizon, it is not surprising that the maritime territory of Australia, including the MoU Box, has become an attractive proposition, despite the severe opportunity costs. While the MoU Box and its marine ecosystem is not free from the threat of exploitative fishing pressure (Adhuri 2013), in comparison to Indonesian waters, this area and the Australian waters around it are relatively under-utilised.

The elephant in the room is the close association between Indonesian fishers and people smuggling (see chapter 8 this volume). Given factors such as global refugee flows and widespread poverty in eastern Indonesia, this issue will not disappear in the short term (see chapter 7 in this volume). We argue that one way to encourage poverty-stricken Indonesian fishermen to turn their back on people smuggling is to provide them with increased income and security. Enhancing the employment of Indonesian fishing crew on Australian fishing vessels could achieve this. As well as receiving income to send back home, with appropriate training and debriefing, Indonesian migrant workers could also develop new skills and techniques in fisheries management, processing and marketing, all of which would be of potential use on their return to Indonesia. Admittedly, this does little to disrupt people-smuggling operations in Indonesia or Malaysia or relieve the bottleneck of asylum seekers ensconced in both countries. Nevertheless, at the very least it could potentially decrease the number of vessels making the dangerous voyage to Australian territory, which in recent years has led to the tragedy of many hundreds of lives lost at sea. The fact that Australian authorities apprehend and destroy all IUU vessels has ensured that the vessels themselves are, at best, in poor condition and, at worst, unseaworthy. Crewing such a vessel, therefore, is an act of great desperation, with many Indonesian fishermen sentenced to a mandatory five years in an Australian prison for facilitation and profiteering from people smuggling.

\section{Conclusion}

This chapter has highlighted the common knowledge that, before the full impact of European settlement in Australia was felt, Indonesian trepangers and the Indigenous inhabitants of northern Australia had cooperated closely and traded for nearly two centuries. In more recent times, temporary migration flows to Australia from Indonesia have been overshadowed by the close 
association between Indonesian fishers and the people-smuggling trade, which involves the transportation of irregular migrants to Australian territory. We have argued, however, that one way to encourage fishers to turn their back on people smuggling is to provide them with increased income and security, which could provide a measure of what is known as 'reliable prosperity'. Evaluations of New Zealand's Pacific Islander seasonal workers scheme have demonstrated that it is having a positive development impact in the Pacific. Although the number of migrant workers participating in an Australian equivalent would be much lower than the RSE, it could be argued that a similar temporary foreign labour programme in the Australian fishing industry, which hitherto appears to be favouring Indonesian fishers, might manifest some modest development benefits. Besides the direct benefits of employment, skills training and remittances, in terms of Australia's maritime border issues, it seems reasonable to assume that fishing and deck hands with experience working in Australian waters would become familiar with Australian maritime enforcement arrangements. On their return, they could spread reliable information about the dangers of people smuggling and the benefits of better money earned legally.

It is ironic that immediately north of Australia lie many large fleets of Indonesian fishing vessels, manned by fishers facing a seemingly neverending struggle over marine resources that are diminishing as a result of unsustainable fishing. In Indonesia, these fishers are known to be among the poorest of the poor, spurring them to commit extremely desperate acts such as ferrying irregular migrants to Australia. Increasing the numbers of Indonesian fishing crews working in Australian waters could make a modest contribution in addressing this situation. We reiterate that the development benefits of employing relatively small numbers of Indonesian deck and fishing hands in Australia would be modest at best. Nonetheless, considering the ongoing nature of what has been widely referred to as Australia's 'asylum-seeker crisis', it would be a step in the right direction. Travelling on unseaworthy fishing boats is a dangerous situation both for Indonesian fishing crews and asylum seekers, the latter of which are often already traumatised and in dire need of protection and safety. The key lesson of this chapter, however, is much broader in nature. That is, both Australia and Indonesia need to recognise that the best way to overcome ongoing issues such as asylum seeker flows, people smuggling, overfishing, labour shortages and so on, is through a regional framework. In terms of better managing legal and illegal migration in Southeast Asia and the Asia-Pacific region in general, the best way to make progress is through closer cooperation and collaboration between the key countries in the neighborhood. New 
Zealand, for example, has drawn on its close ties with its Pacific neighbours to encourage a culture of circular migration. Likewise, this chapter suggests that the shared history between Indonesia and Australia could be used as a launching pad for more constructive migration flows from Indonesia to Australia - that is, a history in which Indonesia's boats in search of the humble sea cucumber once drew the people of these two countries and the rest of the world together rather than pushing them apart.

Finally, while this chapter and the other chapters of this book have highlighted the importance of tackling regular and irregular migration on a regional basis, we also need to be vigilant in recognising the close association between migration and other salient themes, such as the capacity of migration in general and labour migration in particular to act as a development strategy for the sending countries. We also need to be much more up front about the many benefits of migration for the receiving countries, including the injection of both low and high-skilled labour. Ultimately we need to normalise migration, which would go some way towards lessening the general angst that is associated with migration, especially when it is discussed in the international or transnational context.

The authors would like to thank Jim Prescott and Campbell Macknight for their insightful comments and criticisms of an earlier draft of this chapter. Thanks also to Colin Barlow, Dale Druhan, Trixi Madon, Jean-Luc Maurer, Antje Missbach and various government officials, as well as fishing industry representatives, entrepreneurs, operators and their employees in both Australia and Indonesia who gave us their time and views and shared important information with us. This preliminary study is exploratory in nature and the authors are solely responsible for any shortcomings or errors. 


\section{Bibliography}

Abbas, H. (2011), 'Cycle of victimization: RI children in prisons', Jakarta Post, 5 December. www. thejakartapost.com/news/2011/12/05/cycle-victimization-ri-children-prisons.html.

$A B C$ News, 'Australia to fast-track visas for US tradies', 2 April 2012. www.abc.net.au/news/201204-02/new-visa-deal-between-us-and-australia/3927776.

Abdurrahman, M. N. (2010), '30 imigran gelap asal Afghanistan kabur dari Rudenim Sulsel', DetikNews, 10 February. news.detik.com/read/2010/02/10/130629/1296661/ 10/30-imigrangelap-asal-afghanistan-kabur-dari-rudenim-sulsel.

Acharya, A. (2003), 'Democratisation and the prospects for participatory regionalism in Southeast Asia', Third World Quarterly 24 (2): 375-90.

Acharya, A. (2008), Singapore's foreign policy: The search for regional order. New Jersey: World Scientific.

Acosta, D. (2009), 'The good, the bad and the ugly in EU migration law: Is the European Parliament becoming bad or ugly?', European Journal of Migration and Law 11: 19-39.

Adhuri, D.S. (2013), 'Traditional and 'modern' trepang fisheries on the border of the Indonesian and Australian fishing zones' in M. Clark \& S.K. May (eds.) Macassan history and heritage: Journeys, encounters and influences, 183-203. Canberra: ANU E Press.

Al Tikriti, N. (2010), 'There go the neighbourhoods: Policy effects vis-a-vis Iraqi forced migration,' in D. Chatty \& B. Finlayson (eds.), Dispossession and displacement: Forced migration in the Middle East and North Africa, 249-272. Oxford: Oxford University Press.

Alford, P. (2012), 'Mission in Java stopped boats before Canberra quit', The Australian, 17 March.

Allen, P. (2011), 'Javanese cultural traditions in Suriname', Review of Indonesian and Malaysian Affairs 45 (1 \& 2): 199-223.

Aly, A. (2011), Terrorism and globalsecurity: Historical and contemporary perspectives. Melbourne: Palgrave Macmillan.

Amin, M. \& A. Mattoo. (2005), Does temporary migration have to be permanent?, Washington DC: World Bank.

Amnesty International (2007), 'Human rights situation deteriorating on Nauru', 4 September. www.amnesty.org.au/news/comments/2733/.

Amnesty International (2008), Iraq: Rhetoric and Reality: The Iraqi Refugee Crisis, MDE 14/011/2008. London.

Amnesty International (2009), State of the world's human rights. report2009.amnesty.org/

Amnesty International (2010), 'Abused and abandoned: Refugees denied rights in Malaysia,' ASA 28/010/2010. www.amnesty.org/en/library/asset/ASA28/010/2010/en/2791c659-7e4d4922-87e0-940faf54b92c/asa280102010en.pdf.

Amnesty International (2012), Indonesia: Asylum-seeker tortured to death in detention, index number: ASA 21/008/2012. www.amnesty.org/en/library/info/ASA21/008/2012/en.

Andaya, L. (2008), Leaves of the same tree: Trade and ethnicity in the Straits of Melaka. Honolulu: University of Hawaii Press.

Anderson, B. (1991), Imagined communities: Reflections on the origin and spread of nationalism. London and New York: Verso.

Anderson, C. (1998), 'When in doubt, use proxies: Attitudes toward domestic politics and support for European integration', Comparative Political Studies 31: 569-601.

Arendt, H. (1973), The origins of totalitarianism. New York, NY: Harcourt Brace Jovanovich.

Arifianto, A. (2009), 'The securitization of transnational labor migration: The case of Malaysia and Indonesia', Asian Politics \& Policy 4 (1): 613-630. 
Arzheimer, K. (2009), 'Contextual factors and the extreme right vote in Western Europe, 19802002', American Journal of Political Science 53 (2): 259-275.

ASRC (Asylum Seeker Resource Centre) (2011), Asylum seekers and refugee: Myths, facts and solutions. www.asrc.org.au/pdf/myths-facts-solutions-info_.pdf

Athukorala, P. \& C. Manning (1999), Structural change and international migration in East Asia. Melbourne: Oxford University Press.

Australian Department of Education, Employment and Workplace Relations (2012), 'Pacific Seasonal Worker Pilot Scheme'. www.deewr.gov.au/Employment/Programs/PSWPS/Pages/ default.aspx.

Australian Department of Immigration and Multicultural and Indigenous Affairs (DIMIA), People Smuggling, Fact Sheet 73, 1 October 2002, Canberra. sievx.com/articles/psdp/DIMIAFactSheet73.pdf.

Australian Fisheries Management Authority (2006), Annual report 2005-2006. Canberra.

Australian Fisheries Management Authority (2007), Annual report 2006-2007. Canberra.

Babacan, H. \& N. Gopalkrishnan (2008), 'New racisms and asylum seekers in Australia', in A. Babacan \& L. Briskman (eds.), Asylum seekers: International perspectives on interdiction and deterrence, 143-157. Newcastle: Cambridge Scholars Publishing.

Balanta Budi Prima (Indonesian Manpower Service) (2010), 'Pengiriman TKI sektor informal ke Malaysia akan dibuka awal April', posted 19 March. balanta.wordpress.com/2010/03/19/ pengiriman-tki-sektor-informal-ke-malaysia-akan-dibuka-awal-april-2010/.

Bali Process (2011), Regional Cooperation Framework. www.baliprocess.net/regional-cooperationframework.

Bambang (2010), ‘44 Imigran gelap kabur dari Rudenim Kupang’, Antaranews, 13 August, www. antaranews.com/news/216061/44-imigran-gelap-kabur-dari-rudenim-kupang.

Bangun, A.K. (2010), 'MoU Tak Jamin TKI Terlindungi', Harian Kompas, 20 November. bisniskeuangan.kompas.com/read/2010/11/20/08194277/MoU.Tak.Jamin.TKI.Terlindungi.

Banting, K. \& W. Kymlicka (eds.) (2006), Multiculturalism and the welfare state. Oxford: Oxford University Press.

Banton, M. (1985), Promoting racial harmony. Cambridge: Cambridge University Press.

Barden, H.S. (2006), 'Terms and conditions of employment (Foreign Workers)/Unionism', paper presented at the LAWASIA Labour Law Conference, Kuala Lumpur, 10-11 August (typescript).

Barry, M. (2012a), 'Are foreign workers really the answer to the resources skills shortage?', The Conversation, 2 March. theconversation.edu.au/are-foreign-workers-really-the-answer-tothe-resources-skills-shortage- 5576 .

Barry, M. (2012b), 'US workers get the nod ... but what does this mean for the local workforce?', The Conversation, 16 April. theconversation.edu.au/us-workers-get-the-nod-but-what-doesthis-mean-for-the-local-workforce-6409.

Bat Ye'or (2005), Eurabia: The Europe-Arab Axis. Cranbury, N.J.: Fairleigh Dickinson University Press.

Battjes, H. (2009), 'The Soering threshold: Why only fundamental values prohibit refoulement in ECHR case law', European Journal of Migration and Law 11: 205-219.

Bauböck, R. (1994), Transnational citizenship:Membership and rights in internationalmigration. Aldershot, UK: Edward Elgar.

Bauböck, R., A. Heller \& A. Zollberg (eds.) (1996), The challenge of diversity: Integration and pluralism in societies of immigration. Aldershot: Avebury.

Bauer, T. \& K. Zimmermann (1999), Assessment of possible migration pressure and its labour market impact following EU enlargement to Central and Eastern Europe. Bonn: IZA. 
Bayuni, E.M. (2010), 'Malaysia's arrogance versus Indonesia's envy', The Jakarta Post, 9 April. www. thejakartapost.com/news/2010/og/04/commentary-malaysia\%E2\%80\%99s-arroganceversus-indonesia\%E2\%80\%99s-envy.html.

$B B C$ News, 'Iraq violence: eight killed in Baquba cafe bomb attacks', 26 April 2012. www.bbc. co.uk/news/world-middle-east-17863432.

Bedford, R. (2012), 'The experience of NZ growers with the RSE', paper presented at the workshop Making Pacific Migration Work: Australian and New ZealandExperiences, Australian National University, Canberra, 3 April.

Bem, K., N. Field, N. MacLellan, S. Meyer \& A. Morris (2007), A price too high: The cost of Australia's approach to asylum seekers. Sydney and Melbourne: A Just Australia and Oxfam.

Berezin, M. (2006), 'Appropriating the "no": the French National Front, the vote on the Constitution, and the "new"', PS: Political Science and Politics 39: 269-272.

BeritAnda.com, 'Komnas HAM Kalbar kunjungi imigran korban penganiayaan', 5 March 2012. beritanda.com/nasional/berita-nasional/keamanan/5570-komnas-ham-kalbar-kunjungiimigran-korban-penganiayaan-html.

Bernhardt, D., S. Krasa \& M. Polborn (2008), 'Political polarization and the electoral effects of media bias', Journal of Public Economics 92: 1092-1104.

Bernstein, N. (2011), 'Companies use immigration crackdown to turn a profit', New York Times, 28 September. www.nytimes.com/2011/og/29/world/asia/getting-tough-on-immigrants-toturn-a-profit.html?pagewanted=all.

Berwick (Breivik), A. (2011) 2083: A European declaration of independence. London.

Bitoulas, A. (2012), Asylum applicants and first instance decisions on asylum applications, second quarter 2011. EuroStat.

Black, R., C. Natali \& J. Skinner (2005), Migration and inequality. Background paper for World Development Report 2006. siteresources.worldbank.org/INTWDR20o6/.../Migration_and_Inequality.pdf

Black, R., G. Engbersen, M. Okólski \& C. Pantiru (eds) (2010), A continent moving West? EU enlargement and labour migration from Central and Eastern Europe. Amsterdam: Amsterdam University Press.

Boeri, T. \& H. Brücker (200o), The impact of Eastern enlargement on employment and labour markets in the EU member states. Brussels: European Commission.

Boeri, T., G.H. Hanson, \& B. McCormick (eds) (2002), Immigration policy and the welfare system: A report for the Fondazione Rodolfo Debenedetti (in association with the William Davidson Institute). Oxford: Oxford University Press.

Bommes, M. \& A. Geddes (eds.) (2000), Immigration and welfare: Challenging the borders of the welfare state. London and New York: Routledge.

Bonin, H. (2002), Eine fiskalische Gesamtbilanz der Zuwanderung nach Deutschland. IZA discussion paper 516 . Bonn: IZA.

Bonin, H. (2006), Der Finanzierungsbeitrag der Auslaender ze den deutschen Staatsfinanzen: eine Bilanz fuer 2004. IZA discussion paper 2444. Bonn: IZA.

Booth, A. (2007), Colonial legacies: Economic and social development in East and Southeast Asia. Honolulu: University of Hawai'i Press.

Borjas, G., R. Freeman \& L. Katz (1996), 'Searching for the effect of immigration on the labor market', American Economic Review 86 (2): 246-251.

Bos, L. \& W. van der Brug (2010), 'Public images of leaders of anti-immigration parties: Perceptions of legitimacy and effectiveness', Party Politics 16 (6): 777-799.

Boswell, C. (2003), 'Burden-sharing in the European Union: Lessons from the German and UK experience', Journal of Refugee Studies 16: 316-335. 
Boswell, C. \& A. Geddes (2011), Migration and mobility in the European Union. Basingstoke: Palgrave Macmillan.

Bottomore, T. (ed.) (1978), Austro-Marxism. Oxford: Clarendon Press.

Bowen, C. (2011), 'Australia country statement', presented at the Fourth Regional Ministerial Conference, Bali, 30 March. www.baliprocess.net/files/BRMC\%2oIV\%20Australia\%2oStatement.docx.

BPC (Border Protection Command). Maritime security threats. www.bpc.gov.au/site/page5777. asp.

Brennan, F. (2012), 'Oakeshott's Malaysia solution loophole', Eureka Street, 15 April. www. eurekastreet.com.au/article. aspx?aeid $=30929$.

Brimelow, P. (1995). Alien nation: Common sense about America's immigration disaster. New York: Random House.

Briskman, L. (2012), 'A clash of paradigms for asylum seekers: Border security and human security', in G. Bee Chen, B. Offord \& R. Garbutt (eds), Activating human rights and peace: Theories, practices and contexts, 270-286. Surrey: Ashgate.

Briskman, L., S. Latham \& C. Goddard (2008), Human rights overboard: Seeking asylum in Australia. Melbourne: Scribe Publications.

Brown, R.P.C., G. Leeves \& P. Prayaga (2012), 'An analysis of recent survey data on the remittances of Pacific island migrants in Australia', paper presented at the workshop Making Pacific Migration Work: Australian and New Zealand Experiences, Australian National University, Canberra, 3 April.

Brubaker, R. (1989), Citizenship and nationhood in France and Germany. Cambridge: University of Cambridge.

Brubaker, R. (1992), Nation and citizenship in the global age: From national to transnational ties and identities. New York: Palgrave.

Brubaker, R. (2001), 'The return of assimilation? Changing perspectives on immigration and its sequels in France, Germany, and the United States', Ethnic and Racial Studies 24 (4): 531-548.

Brücker, H. et al. (2009), Labour mobility within the EU in the context of enlargement and the functioning of the transitional arrangements: Final report. Nürnberg: IAB.

Burke, A. (2001), In fear of security: Australia's invasion anxiety. Annandale: Pluto Press.

Caballero-Anthony, M. (2008), 'Challenging change: Nontraditional security, democracy, and regionalism', in D. K. Emmerson (ed.), Hard choices: Security, democracy, and regionalism in Southeast Asia, 191-218. Stanford, CA:The Walter H. Shorenstein Asia-Pacific Research Center.

Caldwell, C. (2009), Reflections on the revolution in Europe: Immigration, Islam and Europe. London: Allen Lane.

Callick, B. (2012), 'Nauru, PNG question long-stay rule', The Australian, 29 August, www. theaustralian.com.au/national-affairs/nauru-png-question-long-stay-rule/storyfn59niix-1226460236946.

CARAM Asia (2011), Reality check! Rights and legislation for migrant domestic workers across Asia. Kuala Lumpur.

Card, D. (1990), 'The impact of the Mariel boatlift on the Miami labor market', Industrial and Labor Relations Review 43 (2): 245-257.

Card, D. (2004), Is the new immigration really so bad? IZA discussion paper 1119. Bonn: IZA.

Case, W. (2009), 'Low-quality democracy and varied authoritarianism: Elites and regimes in Southeast Asia today', The Pacific Review 22 (3): 255-269.

Castles, S. (1984). Here for good: Western Europe's new ethnic minorities. London: Pluto Press. Castles, S. \& M. Miller (1993), The age of migration. New York: Guilford Press. 
Castles, S. \& M. Miller (1998), The age of migration: International population movements in the modern world (2nd ed.). Basingstoke: Macmillan.

Castronova, E., H. Kayser, J. Frick \& G. Wagner (2001), 'Immigrants, natives and social assistance: Comparable take-up under comparable circumstances', International Migration Review 35 (3): 726-748.

Central Intelligence Agency (2011), The World Factbook. Washington, DC.

Chambers, P. (2010), 'The rising tide of border security', Inside Story, 28 July. inside.org.au/tag/ peter-chambers/.

Chin, C.B.N. (2008), "Diversification" and "privatisation”: Securing insecurities in the receiving country of Malaysia', The Asia Pacific Journal of Anthropology 9 (4): 285-303.

Cholewinski, R. (2010), 'Labour migration and the rights of migrant workers' in A. Edwards and C. Ferstman (eds.) Human Security and Non-Citizens: Law, Policy and International Affairs, 273-313. Cambridge: Cambridge University Press.

Choo, P. (2008), 'Population status, fisheries and trade of sea cucumbers in Asia', in V. ToralGranda, A. Lovatelli and M. Vasconcellos (eds.), Sea cucumbers: A global review offisheries and trade, 81-110. Rome: Food and Agriculture Organization.

Clark, M. (2011), 'Indonesia's postcolonial regional imaginary: From a "neutralist" to an "alldirections" foreign policy', Japanese Journal of Political Science 11 (2): 287-304.

Clark, M. \& S.K. May (eds.) (2013), Macassan history and heritage: Journeys, encounters and influences. Canberra: ANU E Press.

Cleary, P. (2010), 'Local fishers to opt out to foreign boats', The Australian, 27 December. www. theaustralian.com.au/news/nation/local-fishing-fleet-to-opt-out-to-foreign-boats/storye6frg6nf-1225976467846.

Collyer, M. (2010), 'Stranded migrants and the fragmented journey', Journal of Refugee Studies $23(3): 273-293$.

Commonwealth Fisheries Association (2012), 'New maritime laws to increase fishing industry labour shortages', media release, 16 March. comfish.com.au/wp-content/uploads/2012/03/ CFA-Media-Release-New-maritime-laws-to-increase-fishing-industry-labour-shortages16-March-2012.pdf.

Council of the European Union (2004), Council document 14615/05-Common basic principles for immigrant integration policy in the $E U$.

Cribb, R. \& L. Narangoa (2004), 'Orphans of empire: Divided peoples, dilemmas of identity, and old imperial borders in East and Southeast Asia', Comparative Studies in Society and History 46 (1): 164-187.

Crouch, M. \& A. Missbach (2013), Trials of people smugglers in Indonesia: 2007-2012, Policy paper 1, Centre for Indonesian Law, Islam and Society, University of Melbourne.

Dacyl, J. \& C. Westin (eds) (200o), Governance and cultural diversity. Stockholm: CEIFO.

Dalton, R. \& R. Eichenberg (1998), 'Citizen support for policy integration.' in W. Sandholtz \& A. S. Sweet (eds.), European Integration and Supranational Governance, 250-282. Oxford: Oxford University Press.

Department of Justice and Human Rights, Directorate General of Immigration, Indonesia (2002), Directive from the Director General of Immigration No.: F-IL.01.10-1297 Re: Procedures regarding aliens expressing their desire to seek asylum or refugee status, 30 September, Jakarta.

Devadason E.S. \& Chan W.M. (2010), A critical appraisal of policies and laws regulating migrant workers in Malaysia. www.researchgate.net/publication/228434568_A_Critical_Appraisal_of_Policies_and_Laws_Regulating_Migrant_Workers_in_Malaysia. 
Dösch, J. (2008a), 'Sovereignty rules: Human security, civil society, and the limits of liberal reform' in D.K. Emmerson (ed.), Hard choices: Security, democracy and regionalism in Southeast Asia, 59-9o. Stanford: The Walter H. Shorenstein Asia-Pacific Research Center.

Dösch, J. (2008b), 'ASEAN's reluctant liberal turn and the thorny road to democracy promotion', The Pacific Review 21 (4): 527-545.

Dustmann, C. \& I. Preston (2007), 'Racial and economic factors in attitudes to immigration', The B.E. Journal of Economic Analysis \& Policy 7 (1): 1-39.

Dustmann, C., Frattini, T. \& C. Halls (2010), 'Assessing the fiscal costs and benefits of A8 migration to the UK', Fiscal Studies 31 (1): 1-41.

DutchNews (2011a), 'Council of Europe criticises Dutch family reunification policy'. www. dutchnews.nl/news/archives/2011/o2/council_of_europe_criticises_d.php

DutchNews (2011b), 'Minister wants to slash non-EU work permits'. www.dutchnews.nl/news/ archives/2011/04/minister_wants_to_slash_noneu.php

DutchNews (2012), 'Romanians, Bulgarians to still face Dutch restrictions'. www.dutchnews. nl/news/archives/2011/11/romanians_bulgarians_to_still.php

Duvall, F. (2006), 'Irregular migration: A global, historical and economic perspective', in F. Duvall (ed.), Illegal immigration in Europe: Beyond control?, 14-39. Basingstoke: Palgrave.

Duvall, F. \& B. Jordan (2003), 'Immigration control and the management of economic migration in the United Kingdom: Organisational culture, implementation, enforcement and identity process in public services', Journal of Ethnic and Migration Studies 29 (2): 299-366.

Edwards, A. \& C. Ferstman (2010), 'Humanising non-citizens: Convergence of human rights and human security', in A. Edwards \& C. Ferstman (eds.), Human Security and Non-Citizens: Law, Policy and International Affairs, 3-46. Cambridge: Cambridge University Press.

European Eelection Studies, European Parliament Election Study 2009, [Voter Study and/or Candidate Study, and/or Media Study, and/or Euromanifesto Study and/or Contextual Data], [Advance/Final] Release, DD/MM/2010, (www.piredeu.eu).

Efantino, F. \& S.N. Arifin (2009), Ganyang Malaysia: Hubungan Indonesia-Malaysia sejak konfrontasi sampai konflik ambalat. Yogyakarta: Bio Pustaka.

Eilenberg, M. (2012) At the edges of states: Dynamics of state formation in the Indonesian borderlands. Leiden: KITLV Press.

El-Agraa, A.M. (2011), The European Union: Economics and policies. Cambridge: Cambridge University Press.

Emmerson, D.K. (1995), 'Region and recalcitrance: Rethinking democracy through Southeast Asia', The Pacific Review 8 (2): 223-248.

Emmerson, D.K. (2008), 'ASEAN's “black swans"', Journal of Democracy 19 (3): 70-84.

European Commission (2005), Communication on a common agenda for integration-framework for the integration of third-country nationals in the European Union, $\mathrm{COM} / 2005 / 0389$. Brussels.

European Commission (2007), Towards a common immigration policy. COM/2007/780. Brussels. European Commission (2011a), European agenda for the integration of third-country nationals, $\mathrm{COM} / 2011 / 455$ final. Brussels.

European Commission (2011b), Guide to the European Citizens' Initiative, Brussels. ec.europa. eu/dgs/secretariat_general/citizens_initiative/docs/guide_eci_en.pdf

European Election Database (2013), European Election Data by Country, 11 November, http:// www.nsd.uib.no/european_election_database/

Expert Panel on Asylum Seekers (2012), Report. Canberra: Australian Government. expertpanelonasylumseekers.dpmc.gov.au/sites/default/files/report/expert_panel_on_asylum_seekers_full_report.pdf. 
Facchini, G. \& A.M. Mayda (2006), Individual attitudes towards immigrants: Welfare-state determinants across countries. London: Centre for Research and Analysis of Migration, Department of Economics, University College London.

Faist, T. (2000), The volume and dynamics of international migration and transnational social spaces. Oxford: Oxford University Press.

Faist, T. (2003), The Europeanization of immigration policies. London: Palgrave Macmillan.

Faist, T. \& A. Ette (eds.) (2007), Europeanization of national policies and politics of immigration. Basingstoke: Palgrave Macmillan.

Fargues, F. (2011), International migration and Europe's demographic challenge. Florence: EUI, Robert Schuman Centre for Advanced Studies.

Favell, A. (2001), Philosophies of integration: Immigration and the idea of citizenship in France and Britain. Basingstoke: Palgrave Macmillan.

Fawn, R. (2009), 'Regions and their study: Wherefrom, what for, and whereto?', in R. Fawn (ed.), Globalising the regional: Regionalising the global, 5-34. Cambridge: Cambridge University Press.

Featherstone, K. \& C. Radaelli (eds.) (2003), The politics of Europeanization. Oxford: Oxford University Press.

Fella, S. (2000), 'A Europe of the peoples? New labour and democratising the EU', in C. Hoskyns \& M. Newman (eds.) Democratizing the European Union: Issues for the twenty-first century, 65-81. Manchester and New York: Manchester University Press.

Fetzer, J. (2000), Public attitudes toward immigration in the United States, France and Germany. Cambridge: Cambridge University Press.

Fic, T., D. Holland, P. Paluchowski, A. Rincon-Aznar \& L. Stokes (2011), Labour mobility within the EU: The impact of enlargement and transitional arrangements, NIESR discussion paper 379. London: National Institute of Economic and Social Research.

Fiske, L. \& L. Briskman (2009), 'The empire strikes back: Refugees, race and the reinvention of empire', in D. Bennett, J. Earnest \& M. Tanji (eds.), People, place and power: Regional and international perspectives, 217-238. Perth: Black Swan Press.

Flitton, D. (2012), 'Global view can help tackle asylum woes', The Age, 6 January. www.theage. com.au/opinion/politics/global-view-can-help-tackle-asylum-woes-20120105-1pmty.html.

Ford, M. (2006), 'After Nunukan: The regulation of Indonesian migration to Malaysia', in A. Kaur \& I. Metcalfe (eds) Divided we move: Mobility, labour migration and border controls in Asia, 228-247. New York: Palgrave MacMillan.

Ford, M. \& Susilo, W. (2010), 'Organising for migrant worker rights: Non-governmental organisations continue to fill the gap in the absence of viable alternatives', Inside Indonesia (100). www.insideindonesia.org/feature/organising-for-migrant-worker-rights.

Foster, M. (2007), 'Protection elsewhere: The legal implications of requiring refugees to seek protection in another state', Michigan Journal of International Law 28: 223-286.

Fox, J.J. \& S. Sen (2002), A study of socio-economic issues facing traditional Indonesian fishers who access the MoU box, Canberra: Department of Sustainability, Environment, Water, Population and Communities.

Francis, A. (2005), 'Expanding the Territory's oldest export business', ABC Rural, Northern Territory, $3^{0}$ May. www.abc.net.au/site-archive/rural/nt/stories/s1380107.htm.

Francis, A. (2006), 'Trepang poachers fined in Kimberley', ABC Rural, Northern Territory, 5 June. www.abc.net.au/site-archive/rural/nt/content/2006/s1655553.htm.

Franklin, M., M. Marsh \& L. McLaren (1994), 'Uncorking the bottle: Popular opposition to European unification in the wake of Maastricht', Journal of Common Market Studies 35: 455-472. 
Freeman, G. (1979), Immigrant labour and racial conflict in industrial societies: The French and British experience 1945-1975. Princeton: Princeton University Press.

Freeman, G. (1995), 'Modes of immigration policies in liberal democratic states', International Migration Review 29 (4): 881-601.

Freeman, G. (1998), 'The decline of sovereignty? Politics and immigration restriction in liberal states', in C. Joppke (ed.), Challenge to the nation-state, 86-108. Oxford: Oxford University Press.

Freeman, G. (2006), 'Politics and mass immigration', in R. Goodin \& C. Tilly (eds.), The Oxford handbook of contextual political analysis, 636-648. Oxford: Oxford University Press.

Fry, G. (2002), 'The "Pacific solution”?', in W. Maley, A. Dupont, J. Fonteyne, G. Fry, J. Jupp \& T. Do, Refugees and the myth of the borderless world, 23-31. Canberra: Department of International Relations, Australian National University.

Furnivall, J. S. (1948), Colonial policy and practice: A comparative study of Burma and Netherlands India. Cambridge: Cambridge University Press.

Ganter, R. (2006), Mixed relations: Asian-Aboriginal contact in North Australia. Crawley: University of Western Australia Press.

Garcés-Mascareñas, B. (2012), Labour migration in Malaysia and Spain:Markets, citizenship and rights. Amsterdam: Amsterdam University Press.

Geddes, A. (2000), Immigration and European integration: Towards fortress Europe? Manchester and New York: Manchester University Press.

Geddes, A. (2003), The politics of migration and immigration in Europe. London: Sage.

Geddes, A. (2005), 'Getting the best of both worlds? Britain, the EU and migration policy', International Affairs 81 (4): 723-740.

Geddes, A. \& V. Guiraudon (2004), 'Britain, France and the EU anti-discrimination policy: The emergence of an EU policy paradigm', West European Politics 27 (2): 334-353.

Germann Molz, J. \& S. Gibson (2007), 'Mobilizing and mooring hospitality', in J. Molz \& S. Gibson (eds.), Mobilizing hospitality: The ethics of social relations in a mobile world, 1-25. Aldershot: Ashgate.

Gibney, M. (2004), The ethics and politics of asylum: Liberal democracy and the response to refugees. Cambridge: Cambridge University Press.

Gibney, M. (2007), 'Forced migration, engineered regionalism and justice between states', in S. Kneebone \& F. Rawlings-Sanaei (eds.), New regionalism and asylum seekers: Challenges ahead, 57-77. New York: Berghahn Books.

Gibson, J \& D. McKenzie (2011), 'Australia's Pacific Seasonal Worker Pilot Scheme (PSWPS): Development impacts in the first two years', University of Waikato Department of Economics, Working Paper in Economics o9/11, June.

Gibson, J. \& I. Razak (2011), 'Illegal fishing captures fall in Top End waters', ABC News, 29 April. www.abc.net.au/news/2011-04-29/illegal-fishing-captures-fall-in-top-end-waters/2701078.

Gibson, R. (2002), The growth of anti-immigrant parties in Western Europe. Lewiston, NY: Edwin Mellon Press.

Gibson, S. (2007), 'Abusing our hospitality': Inhospitableness and the politics of deterrence,' in J. Germann Molz \& S. Gibson (eds.) Mobilizing hospitality: The ethics of social relations in a mobile world, 159-74. Aldershot: Ashgate.

Gonzalez-Enriquez, C. 'Spain, the cheap model: Irregularity and regularisation as immigration management policies,' European Journal of Migration and Law 11: 139-157.

Goodwin-Gill, G. \& J. McAdam (2007), The refugee in international law (3rd ed.) Oxford: Oxford University Press. 
Gordon, M. (2012), 'Call to end people smugglers' 5-year terms', The Age, 19 January. www.theage. com.au/national/call-to-end-people-smugglers-5year-terms-20120118-1q6kw.html.

Gott, C. \& K. Johnston (2002), The migrant population in the UK: Fiscal effects. London: Home Office.

Government of Indonesia (1999a), Undang-undang Republik Indonesia Nomor 37 Tahun 1999 tentang Hubungan Luar Negeri.

Government of Indonesia (1999b), Undang-undang Republik Indonesia Nomor 39 Tahun 1999 tentang Hak Asasi Manusia.

Government of Indonesia (2006), Undang-undang Republik Indonesia Nomor 12 Tahun 2006 tentang Kewarganegaraan Republik Indonesia.

Government of Indonesia (2011), Undang-undang Republik Indonesia Nomor 11 Tahun 2011 tentang Keimigrasian.

Gradstein, L. (2006), 'Questioning deterrence policies in the mandatory detainment of asylum seekers', D. Psych. thesis, Deakin University.

Grewcock, M. (2009), Border crimes: Australia's war on illicit migrants. Sydney: Institute of Criminology Press.

Guiraudon, V. (2000), 'The Marshallian triptych reordered: The role of courts and bureaucracies in furthering migrants' social rights', in M. Bommes \& A. Geddes (eds.), Immigration and welfare: Challenging the borders of the welfare state, 71-89. London and New York: Routledge.

Habermas, J. (1994), 'Struggles for recognition in the democratic constitutional state' (S.W. Nicholsen, trans.), in A. Gutmann (ed.), Multiculturalism, 105-107. Princeton: Princeton University Press.

Hage, G. (2003), Against paranoid nationalism. Sydney: Pluto Press.

Hammar, T. (1990), Democracy and the nation-state: Aliens, denizens, and citizens in a world of international migration. Aldershot: Avebury.

Hamzirwan (2010), 'TKI: nasib pahlawan devisa di negeri citra', Harian Kompas, 19 November. bisniskeuangan.kompas.com/read/2010/11/19/08161095/Nasib.Pahlawan.Devisa.di.Negeri. Citra.

Hansen, J. \& M. Lofstrom (2003), 'Immigrant assimilation and welfare participation: Do immigrants assimilate into or out of welfare?' Journal of Human Resources 38 (1): 74-98.

Hansen, J. \& M. Lofstrom (2009), 'The dynamics of immigrant welfare and labor market behaviour', Journal of Population Economics 22: 941-970.

Haryanto, U. (2012), 'Komnas HAM calls for probe after asylum seeker's death', Jakarta Globe, 3 March. www.thejakartaglobe.com/home/komnas-ham-calls-for-probe-after-asylumseekers-death/502166.

Hassan, R. (2008), Inside Muslim minds. Carlton: Melbourne University Press.

Hathaway, J.C. (2005), The rights of refugees under international law. Cambridge: Cambridge University Press.

Hathaway, J.C. 'The Michigan Guidelines on Protection Elsewhere, adopted January 3, 2007', Michigan Journal of International Law 28: 207-221.

Hatton, T. \& J. Williamson (2005), Global migration and the world economy: Two centuries of policy and performance. Cambridge, Mass: MIT Press.

Hay, D. \& S. Howes (2012), Australia's Pacific Seasonal Worker Pilot Scheme: Why has takeup been so low? Development Policy Centre discussion paper 17. Canberra: Crawford School of Economics and Government, Australian National University. devpolicy.org/ australia $\%$ E2\%8o\%99s-pacific-seasonal-worker-pilot-scheme-why-has-take-up-been-solow/dp-17-austrlaias-pacific-seasonal-workers-scheme/. 
Hector, C. (2012a), 'Intipati bantahan mengenai "contractor for labour", "outsourced worker", Pejuang Pekerja Pahang blog posting, 4 April. pejuangpekerjapahang.blogspot.com. au/2012/04/intipati-bantahan-mengenai-contractor.html.

Hector, C. (2012b), 'Workers' and trade union rights in BN- ruled Malaysia (part 2)', Malaysian Insider, 26 August. www.themalaysianinsider.com/sideviews/article/workers-and-tradeunion-rights-in-bn-ruled-malaysia-part-2-charles-hector

Hellyer, H. (2009), Muslims of Europe: The 'other' Europeans. Edinburgh: Edinburgh University Press.

Hennessey, P. (1993), Never again: Britain 1945-1951. London: Vintage.

Higley, J., J. Nieuwenhuysen \& S. Neerup (eds.) (2009), Nations of immigrants: Australia and the US compared. Northampton: Edward Elgar.

Hill, H. (2012), 'Malaysian economic development: Looking backward and forward', in Tham Siew Yean and Ragayah Haji Mat Zin (eds.), Malaysia's development challenges graduating from the middle, 1-42. Abingdon: Routledge.

Hix, S. \& A. Noury (2007), 'Politics, not economic interests: Determinants of migration policies in the European Union', International Migration Review 41 (1): 182-205.

Hoefte, R. (1998), In place of slavery: A social history of British Indian and Javanese labourers in Suriname. Gainesville: University Press of Florida.

Hollifield, J. (2004a), 'Migration and international relations: The liberal paradox', in H. Entzinger, M. Martiniello \& Catherine Wihtol de Wenden (eds.), Migration between states and markets, 3-19. Aldershot: Ashgate.

Hollifield, J. (2004b), 'France: republicanism and the limits of immigration control', in W. Cornelius, T. Tsuda, P. Martin \& J. Hollifield (eds.), Controlling immigration, 183-215. Stanford: Stanford University Press.

Hollifield, J., V. Hunt, and D. Tichenor (2008), 'The liberal paradox: Immigrants, markets and rights in the United States', SMU Law Review 61 (1): 67-98.

Howes, S. (2010), 'Making migration work: Lessons from New Zealand', East Asia Forum, 16 November. www.eastasiaforum.org/2010/11/16/making-migration-work-lessons-fromnew-zealand/.

Howlett, C. (2011), 'Fishing without borders', ABC Environment, 13 December. www.abc.net.au/ environment/articles/2011/12/13/3389001.htm.

Huff, G, \& G. Caggiano (2007), 'Globalization, immigration and Lewisian elastic labor in preWorld War II Southeast Asia', Journal of Economic History 67 (1): 1-36.

Human Rights Watch (2002), 'By invitation only': Australian asylum policy. New York, NY. www. hrw.org/reports/2002/australia/australia1202.pdf.

Human Rights Watch (2006), The silent treatment: Fleeing Iraq, surviving in Jordan. New York, NY.

Human Rights Watch (2009), 'World report 20o9, country summary: Malaysia', Washington DC. www.hrw.org/sites/default/files/related_material/malaysia.pdf.

Humantrafficking.org (2007), 'Malaysia reconceptualizes its assumptions about human trafficking', News \& Updates, 17 May. www.humantrafficking.org/updates/622/

Huntington, S. (1996), The clash of civilizations and the remaking of world order. New York: Simon and Schuster.

Hutton, M. (2012), 'Drownings on the public record of people attempting to enter Australia irregularly by boat since 1998', 6 February. sievx.com/articles/background/DrowningsTable. pdf.

Ignazi, P. (2006), Extreme right parties in Western Europe. Oxford: Oxford University Press. 
inilah.com, 'Warga Afganistan tewas, pegawai Rudenim tersangka', 3 March 2012. sindikasi. inilah.com/read/detail/1836799/warga-afganistan-tewas-pegawai-rudenim-tersangka.

International Crisis Group (2008), Failed responsibility: Iraqi refugees in Syria, Jordan and Lebanon, International Crisis Group Middle East Report No. 77. www.aina.org/reports/ icgreporto8.pdf.

International Crisis Group (2011), The insurgency in Afghanistan's heartland, Asia Report No. 207. www.crisisgroup.org/en/regions/asia/south-asia/afghanistan/207-the-insurgency-inafghanistans-heartland.aspx.

International Crisis Group (2012), Talking about talks: Toward a political settlement in Afghanistan, Asia Report No. 221. www.crisisgroup.org/en/regions/asia/south-asia/afghanistan/221talking-about-talks-toward-a-political-settlement-in-afghanistan.aspx.

International Organization for Migration (2008), 'Psychosocial distress common among Iraqi refugees, IOM Study Finds', press briefing notes, 4 March. www.iom.int/cms/en/sites/iom/ home/news-and-views/press-briefing-notes/pbn-2008/pbn-listing/psychosocial-distresscommon-among-iraqi.html.

International Organization for Migration (2010a), Indonesia: Annual report 2009, Jakarta. www. iom.or.id/loadpdf.jsp?lang=eng\&pgs=rp\&file=IOM\%2oIndonesia\%2oARog.lo.pdf.

International Organization for Migration (2010b), Labour migration from Indonesia: An overview of Indonesian migration to selected destinations in Asia and the Middle East. Jakarta. www.iom. int/jahia/webdav/shared/shared/mainsite/published_docs/Final-LM-Report-English.pdf.

International Organization for Migration (2010c), Regulating migration: Irregular migration. Jakarta. www.iom.or.id/project/eng/fs/Irregular\%2oMigration\%2oFact\%2oSheet_2010_ eng(lo).pdf.

International Organization for Migration (2011a), 'IOM, Indonesia train marine police to cope with intercepted migrants, combat people smuggling', 9 September, www.iom.int/jahia/ Jahia/media/press-briefing-notes/pbnAS/cache/offonce/lang/ en?entryId=30495.

International Organization for Migration (2011b), 'IOM, Indonesia train police to combat people smuggling', 6 May, www.iom.int/jahia/Jahia/media/press-briefing-notes/pbnAS/cache/ offonce/lang/en?entryId=29611.

International Organization for Migration (2011c), Financial report for the year ended ${ }_{31}$ December 2010.

International Organization for Migration (2011d), 'Irregular migrants statistics under IOM Indonesia programme as per 30 September 2011', unpublished document, Jakarta.

International Organization for Migration (2012), 'Irregular migrants statistics under IOM Indonesia programme as per 30 November 2012', unpublished document, Jakarta.

Ireland, P. (2004), Becoming Europe: Immigration, integration, and the welfare state. Pittsburgh: University of Pittsburgh Press.

Jakarta Post, 'Police officers probed in people smuggling', 26 April 2012. www.thejakartapost. com/news/2012/04/26/police-officers-probed-people-smuggling.html.

Jakes, L. (2012), 'Violence in Iraq: Wave of attacks targeting security forces kills dozens, injures more than 200', Huffington Post, 23 February, www.huffingtonpost.com/2012/02/23/iraqviolence_n_1295687.html.

Jesuit Refugee Service Asia Pacific (2012), The Search: Protection space in Malaysia, Thailand, Indonesia, Cambodia and the Philippines, Bangkok, www.jrs.net/Assets/Regions/APR/media/ files/The_Search.pdf.

Jetschke, A. \& Rüland.J. (2009), 'Decoupling rhetoric and practice: The cultural limits of ASEAN cooperation', The Pacific Review 22 (2): 179-203. 
Jones, J. (2011), 'The Malaysian Solution: Refugees caged and caned in world of pain', Daily Telegraph (Sydney), 26 May. www.dailytelegraph.com.au/archive/national-old/the-malaysiansolution-refugees-caged-and-caned-in-world-of-pain/story-e6freuzr-1226062975918.

Jones, M. (2002), Conflict and confrontation in South-East Asia, 1961-1965: Britain, the United States, Indonesia and the creation of Malaysia. Cambridge: Cambridge University Press.

Jones, S. (2000), Making money off migrants: The Indonesian exodus to Malaysia. Wollongong: Asia 2000 Ltd. and Center for Asia-Pacific Transformation Studies, University of Wollongong.

Joppke, C. (1999), Immigration and the nation-state: The United States, Germany, and Great Britain. Oxford: Oxford University Press.

Joppke, C. (2004), 'Commentary', in W. Cornelius, T. Tsuda, P. Martin \& J. Hollifield (eds.), Controlling immigration, 345-381. Stanford: Stanford University Press.

Joppke, C. (2005), Selecting by origin:Ethnic migration in the liberal state. Cambridge, Mass, and London: Harvard University Press.

Jupp, J. (2007), From White Australia to Woomera: The story of Australian immigration. New York: Cambridge University Press.

Jupp, J. \& M. Clyne (eds) (2011), Multiculturalism and integration: A harmonious relationship. Canberra: ANU E-Press.

Kaczmarczyk, P. \& M. Okólski (2008), 'Demographic and economic impacts of migration on Poland', Oxford Review of Economic Policy 24 (3): 600-625.

Kahanec, M. \& K. Zimmermann (2009), 'Migration in an enlarged EU: A challenging solution?' in M. Kahanec \& K. Zimmermann (eds.), EU labor markets after post-enlargement migration. Bonn: Springer.

Kamal, S. (2010), 'Repatriation and reconstruction: Afghan youth a "burnt generation" in postconflict return', in Chatty, D. \& B. Finlayson (eds.), Dispossession and displacement: Forced migration in the Middle East and North Africa, 147-167. Oxford: Oxford University Press.

Kanapathy, V. (2006), 'Migrant workers in Malaysia: An overview', Country paper prepared for the Workshop on an East Asian Cooperation Framework for Migrant Labour, Kuala Lumpur, 6-7 December, www.isis.org.my/attachments/381_VK_MIGRATION-NEAT_6Deco6.pdf.

Kanapathy, V. (2008), Controlling irregular migration: The Malaysian experience. Bangkok: ILO Regional Office for Asia and the Pacific. www.ilo.org/asia/whatwedo/publications/ WCMS_160587/lang--en/index.htm

Kassim, A. (1987), 'The unwelcome guests: Indonesian immigrants and Malaysian public responses', Southeast Asian Studies 25 (2): 265-78.

Kassim, A. (1995), 'Amnesty for illegal foreign workers in Malaysia: Some attendant Problems', Manusia dan Masyarakat, 9-26.

Kassim, A. (1997), 'Illegal alien labour in Malaysia: Its influx, utilization and ramifications', Indonesia and the Malay World 71: 50-82.

Katsumata, H. (2009), 'ASEAN and human rights: Resisting Western pressure or emulating the West?', The Pacific Review 22 (5): 619-637.

Kaur, A. (2004a), Wage labour in Southeast Asia since 1940: Globalisation, the international division of labour and labour transformations. Basingstoke: Palgrave Macmillan.

Kaur, A. (2004b), 'Crossing frontiers: race, migration and borders in Southeast Asia', International Journal on Multicultural Societies 6 (2): 111-132.

Kaur, A. (2005), 'Indonesian Migrant Labour in Malaysia: From preferred migrants to 'last to be hired' workers', Review of Indonesian and Malaysian Affairs 39 (2): 3-30. 
Kaur, A (2006), 'Order (and disorder) at the border: Mobility, international labour migration and border controls in Southeast Asia', in A. Kaur \& I. Metcalfe (eds.), Mobility: Labour migration and border controls in Asia, 23-51. Basingstoke: Palgrave Macmillan.

Kaur, A. (2007), 'Refugees and refugee policy in Malaysia', UNEAC Asia Papers 18: 77-90.

Keane, B. (2011), 'Cost of detention? \$113,000 per asylum seeker', Crikey, 17 August. www.crikey. com.au/2011/o8/17/detention-centre-cost-of-asylum-seekers/.

Kelly, J. (2011), 'Bench ruling on Malaysia solution slammed as narrow', The Australian, September 2.

Khoo, S., P. McDonald \& G. Hugo (2005), Temporary skilled migrants in Australia: Employment circumstances and migration outcomes. Canberra: Department of Immigration and Multicultural and Indigenous Affairs. www.immi.gov.au/media/publications/pdf/457s_survey_report.pdf

Khoo, S., P. McDonald \& G. Hugo (2006), Temporary skilled migrants'employment and residence outcomes. Canberra: Department of Immigration and Multicultural and Indigenous Affairs. www.immi.gov.au/media/publications/pdf/Temporary_Skilled_Outcomes.pdf.

Klausen, J. (2005), The Islamic challenge: Politics and religion in Western Europe. Oxford: Oxford University Press.

Koettl, J. (2006), The relative merits of skilled and unskilled migration, temporary and permanent labour migration, and portability of social security benefits. Washington DC: World Bank.

Koopmans, R. \& P. Statham (1999), 'Challenging the liberal nation-state? Postnationalism, multiculturalism, and the collective claims making of migrants and ethnic minorities in Britain and Germany', American Journal of Sociology 105 (3): 652-696.

Kraus, P.A. (2008), A Union of Diversity: Language Identity and Polity-Building in Europe. Cambridge: Cambridge University Press.

Kreppel, A. (2002), The European Parliament and the supranational party system. Cambridge: Cambridge University Press.

Krismantari, I. (2010), 'Displaced people big spenders in Puncak', Jakarta Post, 24 June. www. thejakartapost.com/news/2010/o6/24/displaced-people-big-spenders-puncak.html.

Kritz, M. \& H. Zlotnik (1992), 'Global interactions: Migration systems, processes, and policies' in M. M. Kritz, L. Lean Lim \& H. Zlotnick (eds.), International migration systems: A global approach, 1-16. Oxford: Oxford University Press.

Kritzman-Amir, T. (2009), 'Not in my backyard: On the morality of responsibility sharing in refugee law', Brooklyn Journal of International Law 34: 355-393.

Kucera, T., E. Uçarer \& D. Puchala (eds.) (2000), New demographic faces of Europe: The changing population dynamics in countries of Central and Eastern Europe. Berlin: Springer.

Kukoc, K. (2012), 'Australia's migration program: Integrity, flexibility and reform', paper presented at the CPD Immigration Law Conference, Sydney, 9-10 March.

Kundnani, A. (2007), The end of tolerance: Racism in 21st century Britain. London: Pluto Press.

Kurnia, A. (2011), Imigran ilegal: Potret penanganan dan pencegahan dalam perspektif sistem manajemen nasional, IOM, Jakarta.

Kymlicka, W. (1995), Multicultural citizenship: A theory of liberal rights. Oxford: Oxford University Press.

Kymlicka, W. (2003), 'Immigration, citizenship, multiculturalism: Exploring the links', in S. Spencer (ed.), The politics of migration: Managing opportunity, conflict and change, 195-208. Oxford: Blackwell.

Laachir, K. (2007), Hospitality and the limitations of the national mobilizing hospitality: The ethics of social relations in a mobile world. Aldershot: Ashgate. 
Lahav, G. (2004), 'Public opinion toward immigration in the European Union', Comparative Political Studies (37): 1151-1183.

Laurie, V. (2012), 'Flying into trouble', The Weekend Australian, 7-8 April: 13-14.

Layton-Henry, Z. (2004), 'Britain: From immigration control to migration management' in W. Cornelius, T. Tsuda, P. Martin \& J. Hollifield (eds.), Controlling immigration, 297-334. Stanford: Stanford University Press.

Lazuardi, G.C. (2009), Maumu apa, Malaysia? Konflik Indo-Malay dari kacamata seorang WNI di Malaysia. Jakarta: Gramedia Pustaka Utama.

Legomsky, S. (2003), 'Secondary refugee movements and the return of asylum-seekers to third countries: The meaning of effective protection', International Journal of Refugee Law 15 : $567-677$.

Lester, E. (2010), 'Socio-economic rights, human security and survival migrants: Whose rights? Whose security?', in A. Edwards \& C. Ferstman (eds.), Human Security and Non-Citizens: Law, Policy and International Affairs, 314-356. Cambridge: Cambridge University Press.

Levey, G. (2008), Political theory and Australian multiculturalism. New York: Bergahn Books.

Lieven, S. (2012), 'Case report on C-411/10, N.S. and C-493/10, M.E and others, 21 December 2011', European Journal of Migration and Law 14: 223-238.

Lindsey, T. (2002), 'Australia, Indonesia and the boat people', The Diplomat 1 (1): 20-23.

Lindsay, T. \& R. Pulungan (2013), 'Turn back the boats? Why Indonesia isn't happy', The Age, 23July. http://www.smh.com.au/comment/turn-back-the-boats-why-indonesia-isnt-happy20130723-2qfmo.html\#ixzz2jv9o855b

Liow, J. (2003), 'Malaysia's illegal Indonesian migrant labour problem: In search of solutions', Contemporary Southeast Asia 25 (1): 44-64.

Liow, J.C. (2006), The politics of Indonesia-Malaysia relations: One kin, two nations. Abingdon, Oxon: Routledge.

Lloyd, G. (2012), 'Cast out', The Weekend Australian Magazine, 17-18 March: 15-18.

Luedtke, A. (2009), 'Uncovering European Union immigration legislation: Policy dynamics and outcomes', International Migration 49 (2): 1-27.

Mackie, J. (1974), Konfrontasi: The Indonesian-Malaysian dispute,1963-1966. Kuala Lumpur: Oxford University Press.

Macknight, C.C. (1976), Voyage to Marege': Macassan trepangers in Northern Australia. Carlton: Melbourne University Press.

Maclellan, N. (2008), 'Seasonal workers for Australia: Lessons from New Zealand', Farm Policy Journal 5 (3): 43-53.

Malkki, L. (1992), 'National geographic: The rooting of peoples and the territorialization of national identity among scholars and refugees', Cultural Anthropology 7 (1): 24-44.

Malkki, L. (1995), 'Refugees and exile: From "refugee studies" to the national order of things', Annual Review of Anthropology 24: 495-523.

Mares, P. (2006), Labour shortages in Murray Valley horticulture: A survey of growers' needs and attitudes, Working Paper. Melbourne: Swinburne University of Technology, Institute of Social Research.

Mares, P. (2007), 'Objections to Pacific seasonal work programs in rural Australia', Public Policy 2 (1): 68-87.

Marr, D. (2011), Panic: Drugs, kids, blacks, boats. Collingwood: Black Inc.

Marr, D. \& M. Wilkinson (2004), Dark victory (rev. ed.). Sydney: Allen \& Unwin.

Mason, V. (2011) 'The im/mobilities of Iraqi refugees in Jordan: Pan-Arabism, "hospitality" and the figure of the "refugee", Mobilities 6 (3): 353-373. 
Matas, D. (2012), Indonesia and Malaysia-Mission Report, 29 January, Toronto.

Mathew, P. (2012), Reworking the relationship between asylum and employment. Abingdon: Routledge.

McDonald, T. (2012), 'Calls to give backpackers longer visas for tourism work', ABC News, The World Today, 13 February. www.abc.net.au/news/2012-02-13/calls-to-give-backpackerslonger-visas-for-tourism-work/3827296.

McGarry, J. \& M. Keating (eds) (2006), European integration and the nationalities question. Abingdon: Routledge.

McNevin, A. (2011), Contesting citizenship: Irregular migrants and new frontiers of the political. New York: Columbia University Press.

Meliala, A. et al. (2011), Tinjauan kritis terhadap penyelundupan manusia di Indonesia dan berbagai dampaknya, Departemen Kriminologi, Universitas Indonesia in collaboration with Jakarta Centre for Law Enforcement Cooperation.

Menadue, J. (2012), 'A regional cooperation framework', speech to International Association of Refugee Law Judges (Australian chapter), Melbourne, 3 February. www.johnmenadue.com/ population/html_files/regional_framework.html.

Menadue, J., A. Keski-Nummi \& K. Gauthier (2011), A new approach to breaking the stalemate on refugees and asylum seekers. Sydney: Centre for Policy Development.

Messina, A. (1996), 'The not so silent revolution: Postwar migration to Western Europe', World Politics 49 (1): 130-154.

Michaelsen, C. (2012), 'The triviality of terrorism', Australian Journal of International Affairs 66 (4): 431-449.

Migration News (1994) 'Malaysia: A special report', Volume 1, No. 3, http://migration.ucdavis. edu/mn/more.php?id=289_o_3_o

Migration News January (2010), 'Southeast Asia', Volume 17, No. 1, http://migration.ucdavis.edu/ $\mathrm{mn} / \mathrm{more} \cdot \mathrm{php}$ ?id=3580_o_3_o

Milner, A. (2008), The Malays. Chichester: Wiley-Blackwell.

Ministry of Finance, Malaysia (2005), Foreign workers and the Malaysian economy: Extracted from the Economic Report 2004/2005.

Ministry of Justice and Human Rights, Indonesia, Board for Research and Development of Human Rights (2011), Buku pedoman HAM bagi petugas rumah detensi Imigrasi, Jakarta.

Missbach, A. \& F. Sinanu (2011), "The scum of the earth"? Foreign people smugglers and their local counterparts in Indonesia', Journal of Current Southeast Asian Affairs 30 (4): 57-87.

Missbach, A. \& F. Sinanu (2013), 'Life and death in immigration detention', Inside Indonesia, 113. www.insideindonesia.org/current-edition/life-and-death-in-immigration-detention.

Modood, T. (2006), 'Multiculturalism, citizenship and national identity' in Colin Hay (ed.), New directions in political science: Responding to the challenges of an interdependent world. Basingstoke: Palgrave Macmillan.

Mole, N. \& C. Meredith (2010), Asylum and the European Convention of Human Rights. Strasbourg: Council of Europe.

Monshipouri, M. (2010), 'The war on terror and Muslims in the West', in J. Cesari (ed.), Muslims in the West after 9/11: Religion, politics and law, 44-66. Oxford: Routledge.

Monsutti, A. (2010), 'The transnational turn in migration studies and the Afghan social networks', in Chatty, D. \& B. Finlayson (eds.), Dispossession and displacement: Forced migration in the Middle East and North Africa, 45-67. Oxford: Oxford University Press.

Mountz, A. (2010), Seeking asylum: Human smuggling and bureaucracyat the border. Minneapolis: University of Minnesota Press.

Mudde, C. (2007), Populistradicalright parties in Europe. Cambridge: Cambridge University Press. 
Mudde, C. (2013), 'Three decades of populist radical right parties in Western Europe: So what?', European Journal of Political Research 52: 1-19.

Munro, P. (2011), 'People smuggling and the resilience of criminal networks in Indonesia', Journal of Policing, Intelligence and Counter Terrorism 6 (1): 40-50.

Nayagam, J. (1991), 'Labour issues in the plantation sector', paper presented at the National Seminar on Agricultural Commodities. Kuala Lumpur: Malaysian Institute of Economic Research.

Nannestad, P. (2004), 'Immigration as a challenge to the Danish welfare state?', European Journal of Political Economy 20 (3): 755-767.

Nethery, A., B. Rafferty-Brown \& S. Taylor (2013), 'Exporting detention: Australia-funded immigration detention in Indonesia', Journal of Refugee Studies 26: 88-109.

'New Indonesian patrol boats to combat smuggling and crime' (2011), Marine Log. www. marinelog.com/index.php?option\%33 Dcom_content\%26view\%3 Darticle\%26id\%3 D1844: 2012janoo260\%26catid\%3 Di:latest-news\%26Itemid\%3 D107.

New Zealand Department of Labour (2010), Final evaluation report of the recognised seasonal employer policy (2007-2009). Wellington.

New Zealand Department of Labour (2012), 'Working Holidaymaker Extension Visa'. www.immigration.govt.nz/migrant/stream/work/hortandvit/workingholidaymakerextensionvisa.htm.

Norris, P. \& R. Inglehart (2012), 'Muslim integration into Western cultures: Origins and destinations', Political Studies 60 (2): 228-251.

OECD (2011), International migration outlook 2010 - SOPEMI report. Paris.

Oesch, D. (2008), 'Explaining workers support for right wing populist parties in Western Europe: Evidence from Australia, Belgium, France, Norway and Switzerland', International Political Science Review 29: 349-373.

Oke, N. (2012), 'Temporary migration, transnational politics? The politics of temporary migration in Australia', Journal of Intercultural Studies 33 (1): 85-101.

Okólski, M. (ed.) (forthcoming), Europe, the continent of immigrants: Trends, structures and policy implications. Amsterdam: Amsterdam University Press.

One World Nations Online (2011), Population figures by country. www.nationsonline.org/ oneworld/population-by-country.htm.

Ong, A. (2010), 'Token gestures: Despite recent government negotiations, Indonesian migrant workers in Malaysia remain disempowered', Inside Indonesia (100). www.insideindonesia. org/feature/token-gestures.

Oratmangun, D. (2009), 'Working towards a strategic partnership: A perspective from Indonesia on ASEAN-EU relations', paper presented at the conference, EU-ASEAN Relations in the 21st Century: Towards a 'Strategic Partnership', 26-27 November, Monash University, Melbourne.

Ouseley, H. (2001), Community pride not prejudice: Making diversity work in Bradford. Coventry: Institute for Community Cohesion.

Parekh, B. (2006), Rethinking multiculturalism. Basingstoke: Palgrave Macmillan.

Perpitch, N. (2012), 'He's a good man - and a Godsend', The Australian, 31 May.

Peteet, J. (2007), 'Unsettling the categories of displacement', Middle East Report 244. www.merip. org/mer/mer244/unsettling-categories-displacement.

Pevehouse, J. C. (2005), Democracy from above: Regional organizations and democratization. Cambridge: Cambridge University Press. 
Pew Research (2011), 'The future of the global Muslim population', Pew Forum on Religion, 27 May, http://www.pewforum.org/2011/o1/27/the-future-of-the-global-muslim-population/

Phillips, J. (2011), Asylum seekers and refugees: What are the facts? Canberra: Parliamentary Library. www.aph.gov.au/binaries/library/pubs/bn/sp/asylumfacts.pdf.

Phillips, J. \& E. Karlsen (2010), Budget 2010-2011: Immigration: Border protection and detention. Canberra: Parliamentary Library. www.aph.gov.au/About_Parliament/Parliamentary_Departments/Parliamentary_Library/pubs/rp/BudgetReview201011/BorderProtection.

Phillips, J. \& H. Spinks (2012), Boat arrivals in Australia since 1976. Canberra: Parliamentary Library. www.aph.gov.au/About_Parliament/Parliamentary_Departments/Parliamentary_Library/pubs/BN/2011-2012/BoatArrivals.

Phillips, N. (2009), 'Migration as development strategy?: The new political economy of dispossession and inequality in the Americas', Review of International Political Economy 16 (2):231-259.

Piore, M. (1979), Birds of passage: Migrant labor and industrial societies. Cambridge and New York: Cambridge University Press.

Pollard, N., M. Latorre \& D. Sriskandarajah (2008), Floodgates or turnstiles? Post-EU enlargement migration flows to (and from) the UK. London: IPPR.

Portes, A. (1995), 'Economic sociology and the sociology of immigration: A conceptual overview', in A. Portes (ed.), The economic sociology of immigration: Essays on networks, ethnicity and entrepreneurship, 166-212. New York: Russell Sage Foundation.

Poynting, S. \& V. Mason (2006), “'Tolerance, freedom, justice and peace”: Britain, Australia and anti-Muslim racism since 11th September,' Journal of Intercultural Studies 27 (4):365-391.

Poynting, S. \& V. Mason (2007), 'The resistible rise of Islamophobia: Anti-Muslim racism in the UK and Australia before 9/11', Journal of Sociology 43 (1): 61-86.

Poynting, S. \& V. Mason (2008), 'The new integrationism, the state and Islamophobia: Retreat from multiculturalism in Australia', International Journal of Law, Crime and Justice 36 (4): 230-246.

Poynting, S. \& G. Noble (2004), Living with racism: The experience and reporting by Arab and Muslim Australians of discrimination, abuse and violence since 11 September 2001, Report to the Human Rights and Equal Opportunity Commission.

Pritchett, L. 2006, Let their people come: Breaking the gridlock on global labour mobility Washington, DC: Center for Global Development.

Putnam, R. (2000), Bowling alone: America's declining social capital. New York: Simon and Schuster.

Raharto, A. (2007), 'Indonesian labour migration: Issues and challenges', International Journal on Multicultural Societies 9 (2): 219-235.

Ramachelvam, M. (2008), 'A rights-based policy framework and plan of action', paper presented at the Malaysian Bar Council Conference on Developing a Comprehensive Policy Framework for Migrant Labour, February, Kuala Lumpur.

Ratha, D. \& A. Silwal (2012), 'Remittance flows in 2011 - an update' (Migration and Development Brief No. 18). Washington, DC: World Bank, Migration and Remittances Unit.

Raunio, T. (1997), The European perspective: Transnational party groups in the 1989-1994 European Parliament. London: Ashgate.

Refugee Council of Australia (2012), RCOA's analysis of the recommendations of the Expert Panel on Asylum Seekers. Sydney.

Refugees International (2012), 'Afghanistan'. refugeesinternational.org/where-we-work/asia/ afghanistan. 
Reith, P. (2001), Transcript of the Hon Peter Reith MP radio interview with Derryn Hinch ${ }_{13}$ September, ${ }_{3} A K$ Radio. Department of Defence, www.defence.gov.au/minister/ReithSpeechtpl. cfm?CurrentId=999.

Rema Devi P. (1996), Contract labour in peninsular Malaysia. Luala Lumpur: Institut Kajian Dasar.

Riady, J. (2012), 'Asean engagement with Burma shows power of good neighbors', Jakarta Globe, 10 May. www.thejakartaglobe.com/opinion/asean-engagement-with-burma-shows-powerof-good-neighbors/516936.

Richardson, R. (2008), 'Sending a strong message?: The refugee's reception of Australia's immigration deterrence policies'. PhD dissertation, Charles Sturt University.

Rintoul, I. (2011), 'Howard's Pacific Solution didn't stop the boats', Solidarity.net.au, May. www. solidarity.net.au/35/howard's-pacific-solution-didn't-stop-the-boat.

Riphahn, R. (2004), 'Immigration participation in social assistance programs', Applied Economics Quarterly 50 (4): 329-362.

Rizal, Y. \& A. Rafiq ( 2009), 'Opera terang bulan', Tempo, 20 September: 103.

Roddam, M. (2012), 'Discussant: Australia's Pacific seasonal workers scheme', paper presented at the workshop Making Pacific Migration Work: Australian and New Zealand Experiences, Australian National University, Canberra, 3 April.

Rodrik, D. (2007), 'Be our guest', New York Times, 1 June. www.nytimes.com/2007/06/o1/ opinion/o1rodrik.html.

Roorda, M. (2012), 'New Zealand's Recognised Seasonal Employer (RSE) program', paper presented at the workshop Making Pacific Migration Work: Australian and New Zealand Experiences, Australian National University, Canberra, 3 April.

Rüland, J. (2009), 'Deepening ASEAN cooperation through democratization? The Indonesian legislature and foreign policymaking', International Relations of the Asia-Pacific 9 (3):373-402.

Rydgren, J. (2008), 'Immigration sceptics, xenophobes or racists? Radical right-wing voting in six West European countries', European Journal of Political Research 47: 737-765.

Sadiq, K. (2005), 'When states prefer non-citizens over citizens: Conflict over illegal immigration into Malaysia', International Studies Quarterly 49 (1): 101-122.

Sadiq, K. (2009), Paper citizens: How illegal immigrants acquire citizenship in developing countries. Oxford, New York: Oxford University Press.

Saito, M. \& P. Kantor (2010), 'From Mohajer to Hamwatan: The reintegration experiences of second-generation Afghans returning from Pakistan and Iran,' in D. Chatty \& B. Finlayson (eds.), Dispossession and displacement: Forced migration in the Middle East and North Africa, 123-143. Oxford: Oxford University Press.

Samers, M. (2010), 'Strange castle walls and courtyards: Explaining the political economy of undocumented immigration and undeclared employment', in G. Menz \& A. Caviedes (eds.), Labour migration in Europe, 209-232. London: Palgrave Macmillan.

Santoso, F. \& M. Suprihadi (2012), 'RI belum miliki kebijakan soal pengungsi', Kompas, 10 February. internasional.kompas.com/read/2012/02/10/11525341/RI.Belum.Miliki.Kebijakan.Soal. Pengungsi.

Sassen, S. (1996), Losing control? Sovereignty in an age of globalization. New York: Columbia University Press.

Saul, B., J. Mowbray \& I. Baghoomians (2011), 'Resistance to regional human rights cooperation in the Asia-Pacific: Demythologizing regional exceptionalism by learning from the Americas, Europe and Africa', in H. Nasu and B. Saul (eds.), Human rights in the Asia-Pacific region: Towards institution building. Abingdon: Routledge. 
Scheve, K. \& M. Slaughter (2001), 'Labour market competition and individual preferences over immigration policy', Review of Economics and Statistics 83: 133-145.

Scheve, K. \& M. Slaughter (2006), 'Public opinion, international integration, and the welfare state' in S. Bowles, M. Wallerstein \& P. Bardham (eds.), Global and egalitarian redistribution, 217-26o. Princeton: Princeton University Press.

Schimmelfennig, F. \& U. Sedelmeier (eds.) (2005), The Europeanization of Central and Eastern Europe. Ithaca, New York: Cornell University Press.

Sloan, J. (2012), 'EMAs essential for resource project viability', The Australian, 28 May, www. theaustralian.com.au/news/opinion/emas-essential-for-resource-project-viability/storyfnbkvnk7-1226368679754.

Smit, J. (2011), 'The political origins and development of Australia's people smuggling legislation: Evil smugglers or extreme rhetoric', Masters by Research (Social Science) thesis, Edith Cowan University.

Sniderman, P. \& L. Hagendoorn (2007), Multiculturalism and its discontents in the Netherlands: When ways of life collide. Princeton: Princeton University Press.

Snyder, J. (2000), From voting to violence:Democratization and nationalist conflict. New York and London: W.W. Norton \& Company.

Soysal, Y.N. (1994), Limits of citizenship: Migrants and postnational membership in Europe. Chicago: University of Chicago Press.

Spanje, J. (2010), Contagious parties: Anti-immigration parties and their impact on other parties' immigration stances in contemporary Western Europe', Party Politics 16: 563-586.

Sreenevasan, A. (2006), 'Obligations of labour contractors and agents', paper presented at the LAWASIA Labour Law Conference, Kuala Lumpur, 10-11 August.

Sriskandarajah, D., L. Cooley \& H. Reed (2005), Paying their way: The fiscal contribution of immigrants in the UK, London: Institute of Public Policy Research.

Stacey, N. (2007), Boats to burn: Bajo fishing activity in the Australian Fishing Zone. Canberra: ANU E Press.

The Star (2011a), '6P programme starts on July 11', 23 June.

The Star (2011b), 'Crackdown of illegal immigrants to begin on 1 January', 25 June.

The Star (2011c), 'Working for Refugee Rights', 7 November.

The Star (2012) '6P programme nets RM1.5bil in levies for govt', 15 May.

Storesletten, K. (2003), 'Fiscal implications of immigration: A net present value calculation', Scandinavian Journal of Economics 105 (3): 487-506.

Stratton, J. (1998), Race daze: Australia in identity crisis. Sydney: Pluto Press.

Stringer, C., S. Simmons \& D. Coulston (2012), Not in New Zealand's waters, surely?: Labour and human rights abuses aboard foreign fishing vessels. Auckland: New Zealand Asia Institute, University of Auckland.

Suaram (Suara Rakyat Malaysia) (2006), Malaysia human rights report 2005 civil and political rights. Petaling Jaya.

Suaram (Suara Rakyat Malaysia) (2008), Malaysia human rights report 2007 civil and political rights. Petaling Jaya.

Suditomo, K., H. Pudjiarti \& M. Dimyathi (2009), 'Membatik di negeri jiran', Tempo, 20 September: 99-102.

Sukma, R. (2008), 'Political development: A democracy agenda for ASEAN?', in D.K. Emmerson (ed.), Hard choices: Security, democracy and regionalism, 135-150. Stanford: The Walter H. Shorenstein Asia-Pacific Research Center.

Sukma, R. (2009), Democracy building in South East Asia: The ASEAN security community and options for the European Union. Stockholm: International IDEA. 
Suryodiningrat, M. (2004), 'Looking for common values: A community driven ASEAN', Jakarta Post, 9 August.

Susilo, Taufik Adi (2009), Indonesia vs Malaysia: Membandingkan peta kekuatan Indonesia \& Malaysia. Yogyakarta: Garasi.

Sydney Morning Herald, 'Plea to Liberals: Agree to swap deal', 2 November 2011. www.smh.com. $\mathrm{au} /$ national/plea-to-liberals-agree-to-swap-deal-20111102-1mugx.html.

Tascon, S.M. (2010), 'Australia and border protection: Morphing racial exclusion into terrorism', in J. A. Winterdyk \& K. W. Sundberg (eds.), Border security in the Al-Qaeda era, 275-306. Boca Raton: CRC Press.

Tay, S.S.C. (2008), 'Blowing smoke: Regional cooperation, Indonesian democracy, and the haze', in D. K. Emmerson (ed.), Hard choices: Security, democracy, and regionalism in Southeast Asia, 219-240. Stanford, CA: The Walter H. Shorenstein Asia-Pacific Research Center.

Taylor, J. (2009), Behind Australian doors: Examining the conditions of detention of asylum seekers in Indonesia. www.law.monash.edu.au/castancentre/news/ behind-australian-doors-report. pdf.

Taylor, S. (2008), 'Australia's border control and refugee protection capacity-building activities in the Asia-Pacific region', in A. Babacan \& L. Briskman (eds.), Asylum seekers: International perspectives on interdiction and deterrence, 63-81. Newcastle: Cambridge Scholars Publishing.

Taylor, S. (2011a), 'Regional cooperation and the Malaysian solution', Inside Story, 9 May inside. org.au/regional-cooperation-and-the-malaysian-solution/.

Taylor, S. (2011b), 'Between the devil and the deep blue sea', Inside Story, 21 December. inside. org.au/between-the-devil-and-the-deep-blue-sea/.

Taylor, S. (2012), 'MEPs want to stop EU funds reaching far-right parties', EuropeanVoice, 4 April. www.europeanvoice.com/article/imported/meps-want-to-stop-eu-funds-reaching-far-rightparties/74049.aspx.

Taylor, S. \& B. Rafferty-Brown (2010a), 'Difficult journeys: Accessing refugee protection in Indonesia', Monash University Law Review, 36 (3): 1-32.

Taylor, S. \& B. Rafferty-Brown (2010b), 'Waiting for life to begin: The plight of asylum-seekers caught by Australia's Indonesian solution', International Journal of Refugee Law 21: 558-92.

Tenaganita (2007), Fact finding report: Outsourcing in labour or trafficking in migrant labour. Kuala Lumpur.

Tenaganita (2008), The revolving door: Modern-day slavery refugees. Kuala Lumpur.

Termorshuizen, T. (2008), 'Indentured labour in the Dutch colonial empire, 1800-1940', in G. Oostindie (ed.), Dutch colonialism, migration and cultural heritage, 261-314. Leiden: KITLV Press.

Thomson, K. (2012), 'The problem with enterprise migration agreements', The Age, 29 May. www.theage.com.au/opinion/politics/the-problem-with-enterprise-migration-agreements20120529-1zgiv.html.

Tirtosudarmo, R. (2011), 'Migrant workers as a constitutional challenge for Indonesia', paper presented at the conference Migrant Workers in Asia:Policies and Practices in Social Sciences, LIPI Jakarta, 14-15 July.

Triandafyllidou, A. (2009), 'Greek immigration policy at the turn of the 21st century: Lack of political will or purposeful mismanagement?', European Journal of Migration Law 11:159-177.

Triandafyllidou, A. (2010), 'Irregular migration in Europe in the early 21st century', in A. Triandafyllidou (ed.), Irregular migration in Europe: Myths and realities, 1-23. Farnham, Surrey: Ashgate. 
Tripp, C. (2012), 'The seductions of violence in Iraq,' Open Democracy, 23 March. www.opendemocracy.net/charles-tripp/seductions-of-violence-in-iraq.

United Nations (2001), Replacement migration: Is it a solution to declining and ageing populations? New York.

United Nations Development Programme (UNDP) (2009), Overcoming barriers: Human mobility and development. Human Development Report 2009. New York.

United Nations High Commissioner for Refugees (UNHCR) (200o), 'Flight from Indochina', in The state of the world's refugees: Fifty years of humanitarian action, 79-102. www.unhcr.org/ publ/PUBL/3ebfgbado.pdf.

United Nations High Commissioner for Refugees (UNHCR) (2001) 'UNHCR and Malaysia close camp for Vietnamese boatpeople'. Press release, 25 June. www.unhcr.org/3ae6b81838.html

United Nations High Commissioner for Refugees (UNHCR) (2005a), Asylum levels and trends in industrialized countries, 2004: Overview of asylum applications lodged in Europe and nonEuropean industrialized countries in 2004. Geneva: PGDS Division of Operational Support. www.unhcr.org/422439144.html.

United Nations High Commissioner for Refugees (UNHCR) (2005b), 'Last Vietnamese boat refugee leaves Malaysia', 30 August. www.unhcr.org/news/NEWS/43141egd4.html.

United Nations High Commissioner for Refugees (UNHCR) (2006), Asylum levels and trends in industrialized countries, 2005: Overview of asylum applications lodged in Europe and nonEuropean industrialized countries in 2005. Geneva: Division of Operational Services. www. unhcr.org/44153f592.html.

United Nations High Commissioner for Refugees (UNHCR) (2007a), Asylum levels and trends in industrialized countries, 20o6: Overview of asylum applications lodged in Europe and nonEuropean industrialized countries in 2006,' Geneva: Division of Operational Services. www. unhcr.org/460150272.html.

United Nations High Commissioner for Refugees (UNHCR) (2007b), 'Refugee from Myanmar finds farming and friends in Java', 27 November, www.unhcr.org/474c3af64.html.

United Nations High Commissioner for Refugees (UNHCR) (2008), Asylum levels and trends in industrialized countries, 2007: Statistical overview of asylum applications lodged in Europe and selected non-European countries. Geneva. www.unhcr.org/47daae862.html.

United Nations High Commissioner for Refugees (UNHCR) (2009), Asylum levels and trends in industrialized countries 2008: Statistical overview of asylum applications lodged in Europe and selected non-European countries,' Geneva: Division of Programme Support and Management, 24 March, http://www.unhcr.org/49c796572.html.

United Nations High Commissioner for Refugees (UNHCR) (2010), Global trends: Refugees, asylum seekers, returnees, internally displaced and stateless people. Geneva.

United Nations High Commissioner for Refugees (UNHCR) (2011a), Asylum levels and trends in industrialized countries 2010: Statistical overview of asylum applications lodged in Europe and selected non-European countries. Geneva: Division of Programme Support and Management. www.unhcr.org/4d8c5biog.html.

United Nations High Commissioner for Refugees (UNHCR) (2011b), Indonesia external fact sheet, September. www.unhcr.or.id/images/pdf/operationalfactsheet-sept201.pdf.

United Nations High Commissioner for Refugees (UNHCR) (2011c), UNHCR global trends 2011. www.unhcr.org/4fd6f8 7 f9.html.

United Nations High Commissioner for Refugees (UNHCR) (2012a), 'Afghanistan: 2012 UNHCR country operations proflle,' www.unhcr.org/cgi-bin/texis/vtx/ page? page $=49 \mathrm{e} 486 \mathrm{eb} 6 \&$ submit $=\mathrm{GO}$. 
United Nations High Commissioner for Refugees (UNHCR) (2012b), Asylum levels and trends in industrialized countries: Statistical overview of asylum applications lodged in Europe and selected non-European countries: 2011 in review, Geneva: Division of Programme Support and Management. www.unhcr.org/4egbeaa1g.html.

United Nations High Commissioner for Refugees (UNHCR) (2012c), 'Pakistan: country operations profile. www.unhcr.org/pages/49e487016.html.

United Nations High Commissioner for Refugees (UNHCR) (2012d), '2012 regional operations profile - Middle East'. www.unhcr.org/pages/49e45ade6.html.

United Nations High Commissioner for Refugees (UNHCR) (2012e), '2012 UNHCR country operations profile - Iraq'. www.unhcr.org/cgi-bin/texis/vtx/page?page $=49 \mathrm{e} 486426$.

United Nations High Commissioner for Refugees (UNHCR) (2012f), 'UNHCR deplores the death of an asylum seeker in Pontianak, Indonesia', briefing notes, 2 March.

United Nations High Commissioner for Refugees (UNHCR) (2013a), UNHCR Indonesia, March. www.unhcr.org/50oorbda9.html

United Nations High Commissioner for Refugees (UNHCR) (2013b), Malaysia: Figures at a glance, www.unhcr.org.my/About_Us-@-Figures_At_A_Glance.aspx.

'UNHCR harus waspadai warga Iran' (2012), Kompas, 9 March, regional.kompas.com/ $\mathrm{read} / 2012 / 03 / 09 / 02583545 /$ UNHCR.Harus.Waspadai.Warga.Iran.

United Nations Population Division (2001), Replacement migration: Is it a solution to declining and ageing population? United Nations Population Divison.

United Nations Population Division (2011), World Population Policies 2011, http://www.un.org/ en/development/desa/population/publications/policy/world-population-policies-2011.shtml

United States Committee for Refugees and Immigrants (USCRI) (2009), World Refugee Survey 2009. www.refugees.org/resources/refugee-warehousing/archived-world-refugeesurveys/20o9-world-refugee-survey.html

United States Department of State (2007), Trafficking in persons report. Washington, DC. www. state.gov/j/tip/rls/tiprpt/2007/.

United States Department of State (2012), Trafficking in persons report. Washington, DC. www. state.gov/j/tip/rls/tiprpt/2012/.

United States Senate Committee on Foreign Relations (2009), Trafficking and extortion of Burmese migrants in Malaysia and Southern Thailand. Washington, DC: USGPO.

Usman, S. \& I. Din (2009), Ancaman negeri jiran: Dari "GANYANG MALAYSIA" sampai konflik Ambalat. Yogyakarta: MedPress.

Vertovec, S. (1999), 'Conceiving and researching transnationalism', Ethnic and Racial Studies $22(2): 447-462$.

Vertovec, S. \& S. Wessendorf (eds) (2010), The multiculturalism backlash: European discourses, policies and backlashes. London: Routledge.

Vink, M. (2003), 'What is Europeanisation? and other questions on a new research agenda', European Political Science 3 (1): 63-74.

Viviani, N. (1984), The longjourney: Vietnamese migration \& settlement in Australia. Melbourne: Melbourne University Press.

Vossen, K. (2011), 'Classifying Wilders: The ideological development of Geert Wilders and his party for freedom', Politics 31 (3): 179-189.

Weber, L. \& S. Pickering (2011), Globalization and borders:Death at the globalfrontier. Basingstoke: Palgrave Macmillan. 
Weiss, L. (2010), 'Malaysia-Indonesia bilateral relations: Sibling rivals in a fraught family', in N. Gamesan \& R. Amer (eds.) International relations in Southeast Asia: Between bilateralism and multilateralism, 171-198. Singapore: ISEAS Publishing.

West Australian, 'FIFO workers cause "havoc" for Pilbara', 28 March 2012. au.news.yahoo.com/ thewest/a/-/newshome/13288775/pilbara-fifo-workers-cause-havoc-for-residents/.

Wiliams, M.J. (2007), Enmeshed: Australia and Southeast Asia's Fisheries. Lowy Institute for International Policy, Sydney.

Winters, A., T. Walmsley, Z. Wang \& R. Grynberg (2005), 'Relaxing the restrictions on the temporary movement of natural persons: A simulation analysis', Journal of Economic Integration $20(4): 688-726$.

Wood, T. \& J. McAdam (2012), 'Australian asylum policy all at sea: An analysis of PlaintiffM7o/2011 $v$ Minister for Immigration and Citizenship and the Australia-Malaysia arrangement', International and Comparative Law Quarterly 61: 279-300.

World Bank (1995), Malaysia: Meeting labor needs, more workers and better skills. Washington, DC.

World Bank (2006), Global economic prospects 2006: Economic implications of remittances and migration. Washington DC.

Yudhoyono, S.B. (2010), The national speech of the President of the Republic of Indonesia, in The People's Consultative Assembly. The People's Consultative Assembly, Jakarta.

Zagor, M. (2007), 'The dark age art of punitive detention', Canberra Times, 19 March. law.anu. edu.au/sites/all/files/allfiles/zagor_-_19_march_2007.pdf. 



\section{Contributors}

Dedi Supriadi Adhuri is Senior Researcher at the Research Centre for Society and Culture, Indonesian Institute of Sciences.

Linda Briskman is Professor of Human Rights at Swinburne University of Technology (Australia).

Marshall Clark is Senior Lecturer at the School of Politics and International Relations, Australian National University.

James Jupp is Adjunct Associate Professor at the Australian Demographic and Social Research Institute, Australian National University.

Pawel Kaczmarczyk is Assistant Professor at the Faculty of Economic Sciences (Chair of Demography), University of Warsaw.

Amarjit Kaur is Professor of Economic History at the University of New England (Australia).

Magdalena Lesińska is Assistant Professor and Deputy Director of the Centre of Migration Research, University of Warsaw.

Victoria Mason is Lecturer in International Relations at the School of Politics and International Relations, Australian National University.

Penelope Mathew is Professor and Dean of Law at Griffith Law School, Griffith University (Australia).

Antje Missbach is Lecturer at the School of Social Sciences at Monash University, Melbourne.

Marek Okólski is Professor at the Institute for Social Studies at the University of Social Sciences and Humanities and Director of the Centre of Migration Research, University of Warsaw.

Juliet Pietsch is Senior Lecturer in Political Science at the School of Politics and International Relations, Australian National University. 



\section{IIAS Publications}

International Institute for Asian Studies

\section{Global Asia}

Kees van Dijk: Pacific Strife. The Great Powers and Their Political and Economic Rivalries in Asia and the Western Pacific 1870-1914

Global Asia 5, 2015, ISBN 9789089644206

Michiel Baas (ed.): Transnational Migration and Asia. The Question of Return

Global Asia 4, 2015, ISBN 9789089646583

Frédéric Bourdier, Maxime Boutry, Jacques Ivanoff and Olivier Ferrari: From Padi States to Commercial States. Reflections on Identity and the Social Construction of Space in the Borderlands of Cambodia, Vietnam, Thailand and Myanmar

Global Asia 3, 2015, ISBN 978908964659 o

Volker Gottowik (ed.): Dynamics of Religion in Southeast Asia. Magic and Modernity

Global Asia 2, 2014, ISBN 9789089644244

Matthias Maass (ed.): Foreign Policies and Diplomacies in Asia. Changes in Practice, Concepts, and Thinking in a Rising Region

Global Asia 1, 2014, ISBN 9789089645401 
